CAROLINA DELFINI FELICIANO

\title{
FLORA DE MINAS GERAIS - BEGONIACEAE
}

Dissertação apresentada ao Instituto de Biociências da Universidade de São Paulo, para a obtenção do título de Mestre em Ciências, na área de Botânica

Orientador: Dr. Vinicius Castro Souza 


\section{Delfini Feliciano, Carolina \\ FLORA DE MINAS GERAIS - BEGONIACEAE \\ 143 páginas}

Dissertação (Mestrado) - Instituto de Biociências da Universidade de São Paulo. Departamento de Botânica.

1. Begoniaceae 2. Begonia 3. Taxonomia 4. Flora 5. Minas Gerais

I. Universidade de São Paulo. Instituto de Biociências.

Departamento de Botânica.

COMISSÃO JULGADORA:

$\operatorname{Prof}(a) . \operatorname{Dr}(a)$

$\operatorname{Prof}(a) \cdot \operatorname{Dr}(a)$

$\operatorname{Prof}(a) . \operatorname{Dr}(a)$ :

$\operatorname{Prof}(a) . \operatorname{Dr}(a)$

Prof. Dr. Vinicius Castro Souza

Orientador 
Aos meus pais Silvia e Antonio Valdire aos meus avós Olívia Delfini (in memoriam) e Oscar Delfini,

DEDICO

A Deus e ao meu país,

OFEREÇO 
“(...) Um homem precisa viajar. Por sua conta, não por meio de histórias, imagens, livros ou TV. Precisa viajar por si, com seus olhos e pés, para entender o que é seu. Para um dia plantar suas próprias árvores e dar-Thes valor. Conhecer o frio para desfrutar do calor. $E$ o oposto. Sentir a distância e o desabrigo para estar bem sob o próprio teto. $U_{m}$ homem precisa viajar para lugares que não conhece para quebrar essa arrogância que nos faz ver o mundo como imaginamos e não simplesmente como ele é ou pode ser. Que nos faz professores e doutores do que não vimos, quando deveríamos ser alunos $e$ simplesmente ir ver".

Amyr Klink 


\section{AGRADECIMENTOS}

Expresso meus mais sinceros agradecimentos a todos aqueles que, direta ou indiretamente, deram sua contribuição ao longo deste caminho... Concluo este trabalho com a certeza de que sua realização teria sido impossivel sem o apoio de tantas pessoas $e$ algumas Instituições, aos quais agradeço em especial:

Ao Instituto de Biociências (Depto. de Botânica/USP) e ao Laboratório de Sistemática Vegetal (Depto. de Ciências Biológicas ESALQ/USP), pelas instalações e equipamentos disponibilizados; concedida;

À Fundação de Amparo a Pesquisa do Estado de São Paulo (FAPESP), pela bolsa

Ao Instituto Plantarum, pela bolsa concedida durante minha graduação, no início de meus estudos com Begonia,

Ao meu orientador, Vinicius Castro Souza, quem me acolheu na ESALQ desde a minha graduação e acreditou em mim, obrigada pelas oportunidades, sugestões e pelo aprendizado ao longo desses anos;

Aos curadores dos herbários que disponibilizaram materiais de suas coleções, pela acolhida durante as visitas e pelo envio dos materiais de empréstimo, sem os quais a qualidade deste trabalho estaria comprometida. Agradeço também à curadoria do herbário ESA pelo espaço concedido;

À Dra. Maria Cândida H. Mamede, à Msc. Sandra Jules Gomes da Silva e à Dra. Eliane de Lima Jacques, pelas valiosas discussões, sugestões e bibliografias sobre as Begoniaceae;

Ao Márcio Lara, pelas longas horas de dedicação na elaboração e recobrimento das pranchas, pelo cuidado e capricho das ilustrações primorosas;

Aos botânicos Juliana de Paula-Souza e Gerson Oliveira Romão e ao Rodrigo Tsuji, obrigada pela disponibilidade, paciência, pela infatigável persistência na procura das begônias, pelo bom humor e por tornarem as viagens de coleta não somente trabalho;

Aos funcionários do Laboratório de Sistemática Vegetal do Depto. de Ciências Biológicas ESALQ/USP: D. Maria, Sr. Vitor e Ony e aos funcionários do Instituto de Biociências: Helder, Érica e Norberto, pela prontidão, rapidez e alegria em sempre ajudar no possivel;

Aos meus amigos taxonomistas da ESALQ/USP, do IB/USP e da UNICAMP: Andréa, Dani Sampaio, Euder, Fiorella, Flavinho, Gabriel (Gari), Gerson (Sandal), Gu Shimizu, Julianinha, Ju Kuntz, JuPSouza, Léo Meireles, Marcela (Morangosa), Marcelo (Pinus), Marcelo Trovó, Maura, Maurício-Murício, Paulinha, Thiago (Ibiscú), Thiago (Padre), Viviane (Inhóq) e Wellington, pelas tantas vezes que me ouviram falar das begônias, pelo aprendizado, incentivo, alegria, por tornarem mais agradável a rotina do laboratório; 
Aos meus amigos não-taxonomistas, Flavinho (Sivirino), Eduardo (Faroli), Felipe (Fininho), Felipe Barbosa, Flávio (Gronho), Gustava (vulgo Augusta), Hector (Bandido), Marquinho (Mini-mim), Mumu, Pelé, Sandrinha Obando, pelo companheirismo, incentivo, alegria, pelas risadas e pela assistência, mesmo às vezes à distância;

Ao Dr. Luiz Antônio Rochelle, meu mestre de botânica na graduação, obrigada pelo amor às plantas, pelas aulas que contribuíram para a minha escolha profissional, pelo exemplo de vida e sabedoria;

Ao amigo e professor de inglês, Antônio Augusto Bianchi, pela paciência enooorme e pela infatigável persistência durante as aulas, pelos ajustes no abstract, pelas delícias de "Leopoldina City" - cheeses and milk cands - e pelos barbecues regados de muitas risadas:

Aos meus pais, Silvia e Antonio Valdir, meu porto seguro, pelo amor incondicional, por acreditarem e confiarem em mim, pela paciência infinita e pelos conselhos, pelo incentivo, apoio, compreensão, (...), imprescindíveis durante meu Mestrado... AMO VOCÊS!!!!

Aos meus avós, Olívia (in memoriam) e Oscar, meus ídolos, pelo amor, por acreditarem em mim, pelo incentivo, pela preocupação, pelo exemplo de vida, de sabedoria e de simplicidade;

Ao querido amigo Rogerinho, meu guru, pelo estímulo, principalmente nas horas difíceis, pelo carinho, amizade, pela companhia sempre agradabilíssima... Ahhh, e pelo investimento feito com tanto café no banco nas nossas discussões acaloradas sobre os "jirânis", os "tumãtis", sobre assuntos frutíferos, não-frutíferos e sobre assuntos sérios;

Às minhas amigas queridas, Camila, mamãe Gisele, JuPantufa e Morangosa, pelo ombro, carinho, pelos frequentes "vexames", pelos cafés filosóficos, por acrescentar muito mais risadas a esta jornada;

Ao Marconi, pela alegria e devoção (rsrs...), pelos forrós, pelo incentivo, carinho, pela companhia sempre agradável:

Ao Marcinho, pelo amor, pelos sorrisos e companheirismo, pelo bom humor, pela compreensão e cumplicidade, pela paciência inesgotável, apoio e incentivo, por ter-me aguentado nos últimos meses de dissertação, por me completar, me fazer feliz...

A todos vocês, MUITO OBRIGADA (de coração!!!) por terem sido parte deste trabalho! 
ÍNDICE:

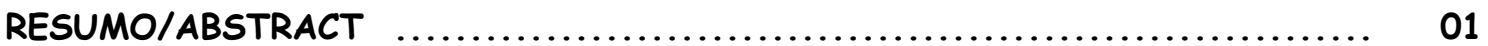

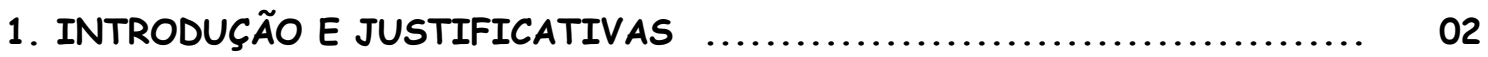

1.1. Begoniaceae Aubl. ................................................................................................ 02

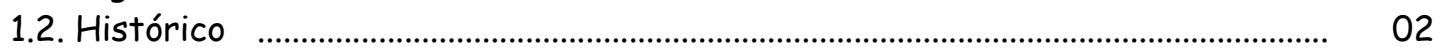

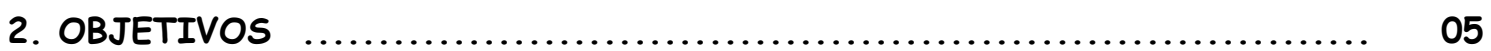

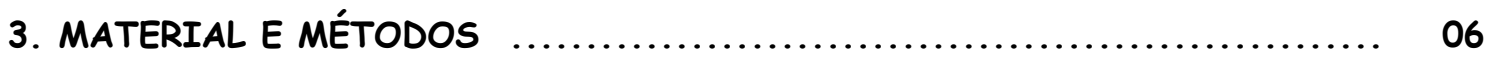

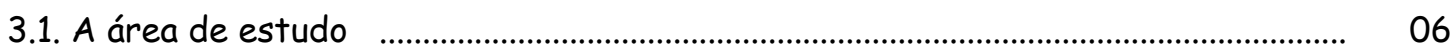

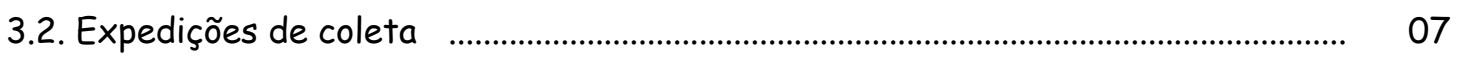

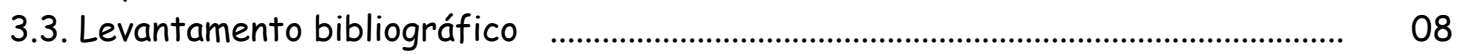

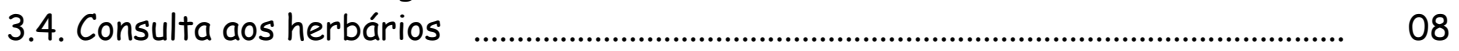

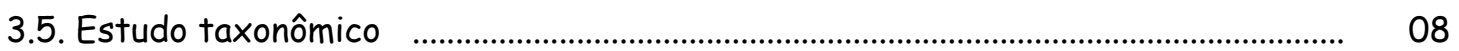

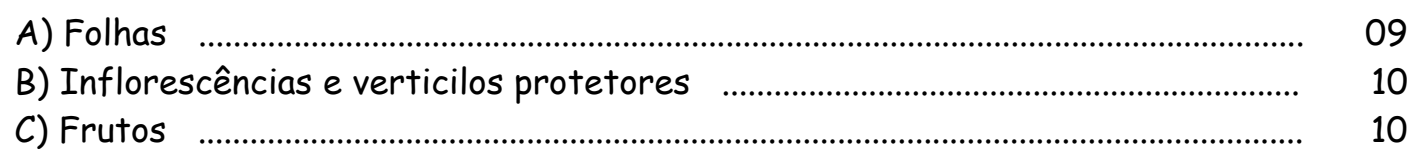

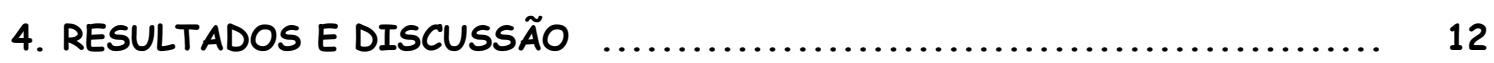

4.1. Descrição da família .......................................................................................... 12

4.2. Descrição do gênero Begonia ...................................................................................... 12

4.3. Chave para as espécies de Begonia L. que ocorrem no Estado de Minas Gerais ... 13

4.4. Descrições das espécies ...................................................................................... 17

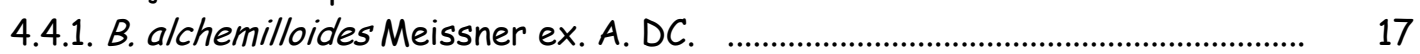

4.4.2. B. altamiroi Brade …........................................................................................... 20

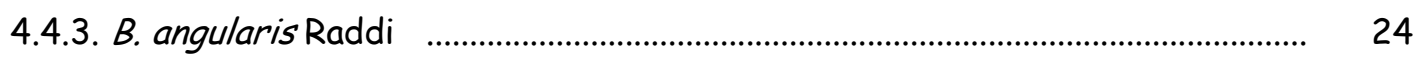

4.4.4. B. angulata Vell. ................................................................................................ 27

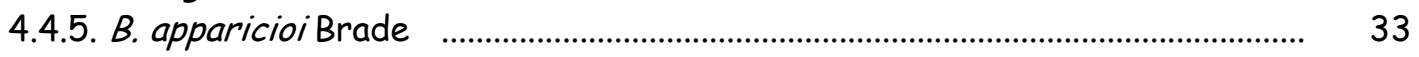

4.4.6. B. convolvulacea (Klotzsch) A. DC. ……………………………………............ 36

4.4.7. B. cucullata Willd. .............................................................................................. 41

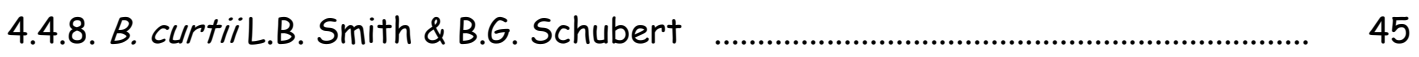

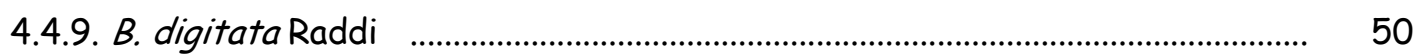

4.4.10. B. fischeri Schrank ......................................................................................... 52

4.4.11. B. fruticosa A. DC. ……………………….................................................... 58

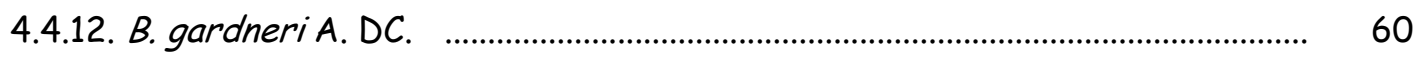

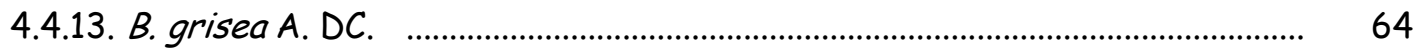

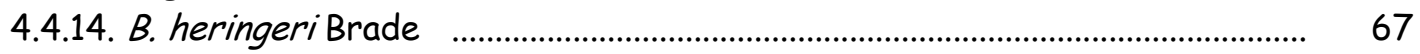

4.4.15. B. hirtellaLink ............................................................................................ 72

4.4.16. B. hugelii (Klotzsch) A. DC. …………….................................................... 74

4.4.17. B. incisoserrata A. DC. ……….................................................................... 78

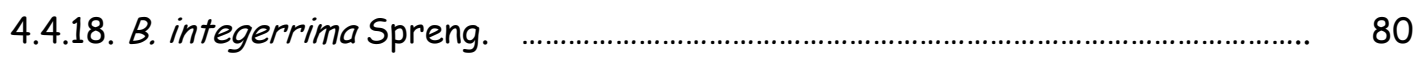

4.4.19. B. Iuxurians Scheidw. ....................................................................................... 84

4.4.20. B. maculata Raddi …........................................................................................ 86

4.4.21. B. moysesii Brade .................................................................................................. 90

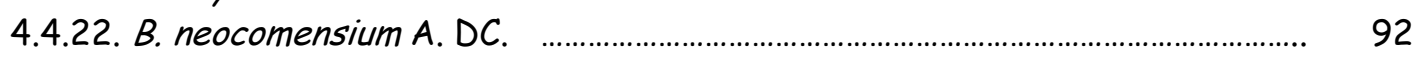

4.4.23. Begonia aff. nuda Irmsch. ............................................................................... 96

4.4.24. B. paulensis A. DC. ............................................................................................ 98

4.4.25. B. platanifolia Schott _.......................................................................................... 102 
4.4.26. B. reniformis Dryand. .................................................................................... 104

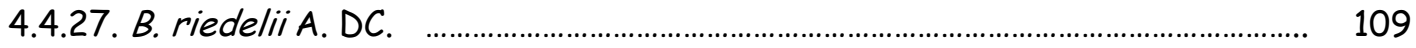

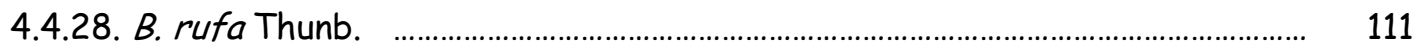

4.4.29. B. ulmifolia Willd. ……..................................................................................... 119

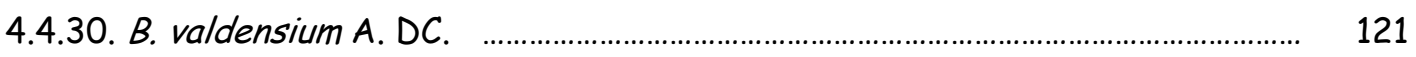

4.4.31. Begonia sp. ....................................................................................................... 125

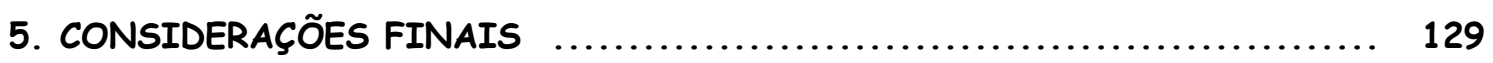

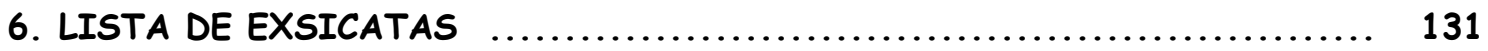

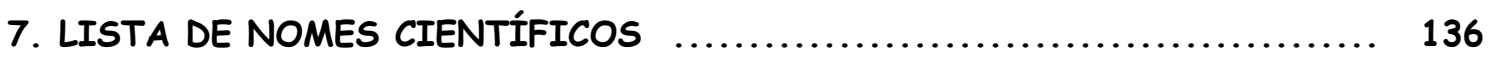

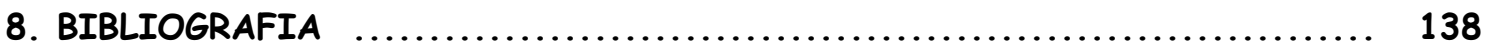

\section{ÍNDICE DE TABELAS:}

TABELA I: Características diagnósticas entre Begonia alchemilloides Meissner ex. A. DC., Begonia fischeri Schrank e Begonia hirtella Link

TABELA II: Características diagnósticas entre Begonia angularis

Raddi, Begonia angulata Vell. e Begonia valdensium A. DC.

TABELA III: Características diagnósticas entre Begonia apparicioi

Brade, Begonia riedelii A. DC. e Begonia valdensium A. DC.

TABELA IV: Características morfológicas de Begonia convolvulacea

(Klotzsch) A. DC., Begonia fruticosa A. DC. e Begonia integerrima Spreng.

TABELA V: Características diagnósticas das variedades de Begonia

cucullata: B. cucullata var. cucullata, B. cucullata var. arenosicola (C. DC.)

L.B. Smith \& B.G Schubert e B. cucullata var. spatulata (Loddiges) J. Golding

TABELA VI: Principais características morfológicas entre

Begonia cucullata Willd. e Begonia semperflorens Link \& Otto

TABELA VII: Características diagnósticas entre Begonia digitata Raddi,

Begonia incisoserrata A. DC. e Begonia luxurians Scheidw.

TABELA VIII: Características diagnósticas entre Begonia gardneri A. DC.,

Begonia reniformis Dryand. e Begonia platanifolia Schott

TABELA IX: Características diagnósticas entre Begonia aff. nuda Irmsch.

e Begonia nuda Irmsch.

TABELA X: Características diagnósticas entre Begonia paulensis

A. DC. e Begonia moysesii Brade

TABELA XI: Características morfológicas de Begonia rufa Thunb.,

Begonia altamiroi Brade e Begonia apparicioi Brade 


\section{ÍNDICE DE FIGURAS:}

Figura 01: Biomas de Minas Gerais, adaptado de GeoMINAS (2009) ........................... 07

Figura 02: A-Comprimento da folha; B- Largura da ala maior da cápsula ...................... 11

Figura 03: Modelo esquemático das inflorescências de Begonia L. ................................... 11

Figura 04: Mapa de distribuição geográfica de B. alchemilloides ........................................ 22

Figura 05: Mapa de distribuição geográfica de B. altamiroi .............................................. 22

Figura 06: (prancha) Begonia alchemilloides: A-G; B. altamiroi: H-K ............................... 23

Figura 07: Mapa de distribuição geográfica de $B$. angularis ........................................... $\quad 30$

Figura 08: Mapa de distribuição geográfica de B. angulata ............................................. 30

Figura 09: (prancha) Begonia angularis: A-F; B. angulata: G-L ....................................... 31

Figura 10: (fotos) B. angularis $A-B$................................................................... 32

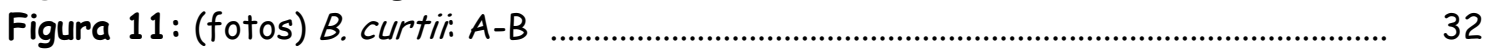

Figura 12: Mapa de distribuição geográfica de B. apparicioi ............................................ $\quad 39$

Figura 13: Mapa de distribuição geográfica de B. convolvulacea ...................................... 39

Figura 14: (prancha) Begonia apparicioi: A-F; B. convolvulacea. G-L ............................... 40

Figura 15: Mapa de distribuição geográfica de B. cucullata ............................................... $\quad 47$

Figura 16: Mapa de distribuição geográfica de B. curtii .................................................. 47

Figura 17: (prancha) Begonia cucullata: A-G; B. curtii: H-K ............................................. 48

Figura 18: (fotos) B. cucullata: A-C ......................................................................... 49

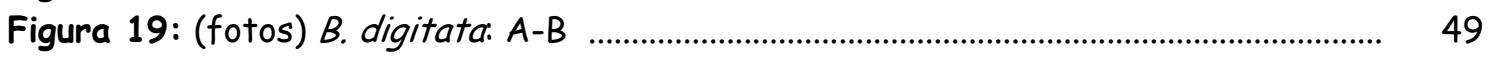

Figura 20: Mapa de distribuição geográfica de B. digitata ............................................. 56

Figura 21: Mapa de distribuição geográfica de B. fischeri .............................................. 56

Figura 22: (prancha) Begonia digitata: A-F; B. fischeri: G-K ........................................ 57

Figura 23: Mapa de distribuição geográfica de B. fruticosa .............................................. 62

Figura 24: Mapa de distribuição geográfica de B. gardneri .............................................. 62

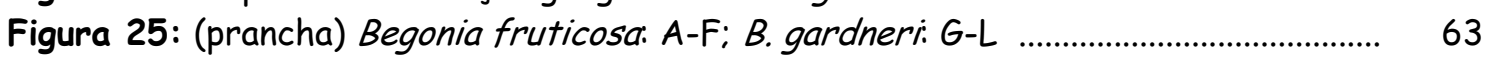

Figura 26: Mapa de distribuição geográfica de B. grisea ................................................. 69

Figura 27: Mapa de distribuição geográfica de B. heringeri ............................................. 69

Figura 28: (prancha) Begonia grisea: A-F; B. heringeri: G-H ........................................ 70

Figura 29: (foto) B. grisea: hábito ................................................................................ 71

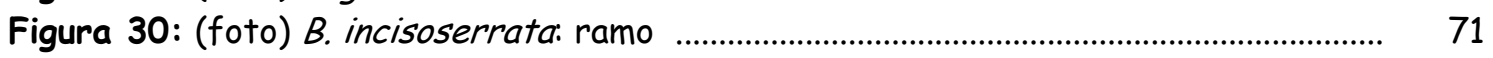

Figura 31 : (fotos) B. luxurians. A-C .................................................................................... 71

Figura 32: Mapa de distribuição geográfica de B. hirtella ................................................. 76

Figura 33: Mapa de distribuição geográfica de B. hugelii .................................................... 76

Figura 34: (prancha) Begonia hirtella. A-F; B. hugelii: G-L ............................................. 77

Figura 35: Mapa de distribuição geográfica de B. incisoserrata ...................................... 82

Figura 36: Mapa de distribuição geográfica de B. integerrima ........................................ 82

Figura 37: (prancha) Begonia incisoserrata: A-F; B. integerrima. G-L ............................ 83

Figura 38: Mapa de distribuição geográfica de $B$. luxurians ............................................ 88

Figura 39: Mapa de distribuição geográfica de B. maculata .............................................. 88

Figura 40: (prancha) Begonia luxurians. A-E; B. maculata. F-I ........................................ 89

Figura 41: Mapa de distribuição geográfica de B. moysesii .............................................. 94

Figura 42: Mapa de distribuição geográfica de B. neocomensium ................................... 94

Figura 43: (prancha) Begonia moysesii: A-F; B. neocomensium: G-L ............................... 95

Figura 44: Mapa de distribuição geográfica de Begonia aff. nuda .................................. 100

Figura 45: Mapa de distribuição geográfica de B. paulensis .............................................. 100

Figura 46: (prancha) Begonia aff. nuda: A-D; B. paulensis. E-J ....................................... 101

Figura 47: Mapa de distribuição geográfica de B. platanifolia ......................................... 107

Figura 48: Mapa de distribuição geográfica de B. reniformis ............................................ 107 
Figura 49: (prancha) B. platanifolia. A-F; B. reniformis. G-K ....................................... 108

Figura 50: Mapa de distribuição geográfica de B. riedelii .............................................. 116

Figura 51: Mapa de distribuição geográfica de B. rufa ................................................... 116

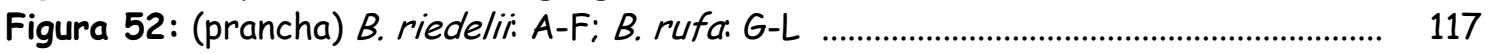

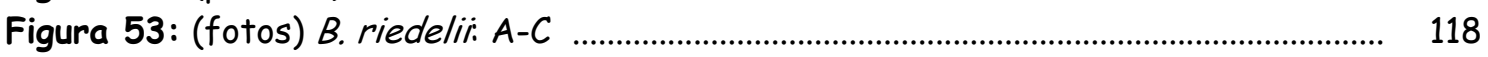

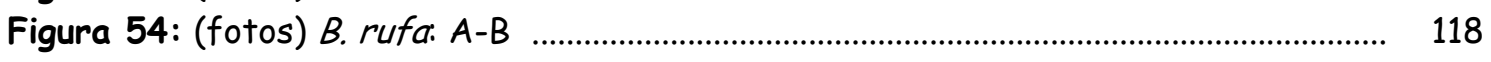

Figura 55: Mapa de distribuição geográfica de B. ulmifolia .............................................. 123

Figura 56: Mapa de distribuição geográfica de B. valdensium ......................................... 123

Figura 57: (prancha) B. ulmifolia: A-E; B. valdensium: F-K ............................................ 124

Figura 58: Mapa de distribuição geográfica de Begonia sp. ............................................ 126

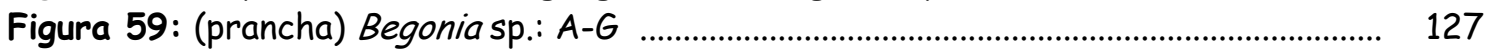

Figura 60: (fotos) Begonia sp.: A-D .............................................................................. 128

Figura 61: Mapa de distribuição do gênero Begonia

em Minas Gerais, adaptado de GeoMINAS (2009) .............................................................. 129 
O presente trabalho refere-se ao levantamento das espécies do gênero Begonia L. (Begoniaceae) de Minas Gerais. A família inclui dois gêneros: Hillebrandia Oliv., monotípico, endêmico do Arquipélago do Havaí e Begonia L. com cerca de 1400 espécies de ervas e subarbustos, largamente distribuídas pelos trópicos e subtrópicos. A maioria das espécies de Begonia apresenta potencial ornamental com folhas vistosas, frequentemente variegadas e diversas espécies são cultivadas no Brasil com essa finalidade. As espécies nativas do Brasil (aproximadamente 240) concentram-se na Mata Atlântica, sendo raras as espécies Amazônicas. De acordo com o levantamento, são encontradas 31 espécies de Begoniaceae em Minas Gerais, crescendo preferencialmente em formações cujo índice higrométrico é bastante elevado, à margem de cursos d'água, nas grotas úmidas, sobre ou entre rochas. O estudo baseou-se no levantamento bibliográfico, consulta a herbários e observações de campo. Constam também descrições, ilustrações, mapas de distribuição geográfica e comentários.

\section{ABSTRACT}

The present work refers to the taxonomic survey of the genus Begonia L. (Begoniaceae) in Minas Gerais State. This family is comprised of two genera: Hillebrandia Oliv., with one species that is endemic to the Hawaiian Islands and the only member of the family native to those islands, and Begonia L. with approximately 1,400 species of herbs and subshrubs that are widely distributed in tropics and subtropics. Most species of the genus Begonia have ornamental potential with showy leaves, frequently variegated and many species are cultivated in Brazil for this purpose. The native Brazilian species (240 - estimated figure) is concentrated on the Atlantic Forest, being Amazonian species rare. According to the survey, there are 31 species of the Begoniaceae in Minas Gerais State, growing up preferably near water, on the moist places, above or among rocks. The study was based on bibliographic review, consults to herbaria, collections and fields observation. Descriptions, illustrations, geographical distribution maps and comments are also presented about each species. 


\section{INTRODUÇÃO E JUSTIFICATIVAS:}

\subsection{Begoniaceae Aubl.:}

Begoniaceae é composta por dois gêneros: Hillebrandia Oliv., monotípico, endêmico do Arquipélago do Havaí e Begonia L. com cerca de 1400 espécies de ervas e subarbustos, largamente distribuídas pelos trópicos e subtrópicos (Golding \& Wasshausen, 2002; Clement et al., 2004; Souza \& Lorenzi, 2008).

A maioria das espécies de Begonia apresenta potencial ornamental com folhas vistosas, frequentemente variegadas e diversas espécies e híbridos são cultivados no Brasil com essa finalidade. (Brade, 1957b; Souza \& Lorenzi, 2008).

Nas Américas encontram-se cerca de 530 espécies; na África, incluindo Madagascar, aproximadamente 150 espécies e na Ásia cerca de 520 espécies (Doorenbos et al., 1998). As espécies nativas do Brasil (aproximadamente 240) concentram-se na Mata Atlântica e estão bem representadas na região sudeste do Brasil, sendo raras as espécies Amazônicas (Duarte, 1961; Smith et al., 1986).

No Estado de Santa Catarina foram registradas 19 espécies (Smith \& Smith, 1971); na Serra do Mar do Estado de São Paulo 39 espécies (Silva \& Mamede, 2001) e na Ilha do Cardoso, litoral sul de São Paulo, foram registradas cinco espécies (Silva, 1992). No Estado do Rio de Janeiro ocorrem aproximadamente 60 espécies, sendo uma nova espécie descrita recentemente (Jacques, 2008) e 20 espécies na Reserva Ecológica de Macaé de Cima (Jacques, 1996). Na Estação Ecológica de Santa Lúcia, no Estado do Espírito Santo, ocorrem 12 espécies (Kollmann, 2006b) e, recentemente, foram descritas cinco novas espécies para este Estado (Kollmann, 2003, 2006a, 2008; Jacques \& Mamede 2004).

Em Minas Gerais, de acordo com Duarte (1961), as cabeceiras do Vale do Rio Doce, a Cadeia do Espinhaço, a Zona da Mata e a Serra da Mantiqueira ao longo do Rio Paraibuna, são locais que apresentam condições de clima bastante favorável para o desenvolvimento de Begoniaceae, entretanto, admite-se que muitas espécies desapareceram com as derrubadas destinadas à agricultura. Ainda assim, na Serra do Cipó foram registradas quatro espécies (Jacques, 1999) e Begonia grisea A. DC. na Serra de Grão Mogol (Jacques, 2003).

\subsection{Histórico:}

Bentham \& Hooker (1883) incluíram Begoniaceae em Passiflorales; Cronquist (1968) posicionou Begoniaceae em Violales, entretanto ressaltou que Begoniaceae, Cucurbitaceae e Datiscaceae deveriam constituir uma nova ordem por não compartilharem características comuns ao restante das Violales tais como ovário unilocular e placentação parietal. Hutchinson (1976), por sua vez, posicionou Begoniaceae em Cucurbitales, o que foi aceito por Dahlgren et al. (1980).

A partir de estudos filogenéticos, destacando-se os realizados por Chase et al., (1993); Swensen et al. (1998); Soltis et al. (2000); Schwarzbach \& Ricklefs (2000); Wagstaff \& Dawson, (2000); Tebbitt et al. (2001); Plana (2003) e APG II (2003), 
Begoniaceae deveria permanecer em Cucurbitales. Além disso, estes estudos revelaram que Datiscaceae sensu stricto aparece como grupo-irmão de Begoniaceae.

No gênero Begonia, tradicionalmente, foram reconhecidas categorias infragenéricas cuja classificação é muito controversa (Doorenbos et al., 1998). O primeiro tratamento monográfico da família foi realizado por Klotzsch (1854, 1855a, 1855b) que dividiu Begoniaceae em duas subfamílias, estas em tribos e propôs 37 gêneros. Tal subdivisão foi feita com base no número de peças do perigônio, na forma das anteras, na persistência ou caducidade dos estiletes, nos ramos e na distribuição das papilas dos estigmas, na forma e subdivisão da placenta, na concrescência dos estiletes, dentre outros.

De Candolle (1859) considerou inconsistente os caracteres utilizados por Klotzsch (1854, 1855a, 1855b) na divisão da família, então, considerou-os como séries e seções e propôs várias sinonímias. Posteriormente, baseando-se em critérios geográficos, De Candolle (1861) dividiu Begoniaceae em três gêneros: Begonia com 323 espécies em 61 seções, Casparya com 23 espécies e Mezierea com 3 espécies. Das 61 seções de Begonia, 34 correspondiam aos gêneros estabelecidos por Klotzsch (1854, 1855a, 1855b).

Anos mais tarde, Warburg (1894) realizou um estudo taxonômico mais abrangente e delimitou geograficamente os gêneros $e$ as seções da família, reconhecendo então 58 seções, das quais 31 eram americanas, 15 asiáticas, 12 africanas e 3 seções de posição duvidosa.

Irmscher (1925) aceitou as propostas de Warburg (1894), reconheceu cinco gêneros em Begoniaceae e 60 seções. Nesse trabalho, Irmscher (1925) propôs uma nova seção asiática, uma nova seção africana e considerou duvidosa a seção com representantes tanto da Ásia quanto das Américas.

Barkley (1972) reconheceu 82 seções e publicou uma chave analítica das mesmas, entretanto as descrições sucintas foram apresentadas por Barkley \& Baranov (1972), basicamente baseadas no conceito de Warburg (1894). De acordo com Jacques (2002), estes trabalhos não solucionaram o problema de delimitação das seções, uma vez que 144 espécies não foram inseridas em nenhuma das seções existentes. Ainda de acordo com esta autora, a tentativa de solucionar tal problema foi criar seções para agrupar as espécies novas descritas e ampliar a circunscrição de algumas seções já existentes para englobar espécies até então não pertencentes a essas seções, o que resultou em seções mal circunscritas com características compartilhadas por uma ou por várias outras seções.

Para justificar o posicionamento taxonômico de determinadas espécies de Begoniaceae, Doorenbos et al. (1998) apresentaram novas abordagens no agrupamento das seções, tais como a utilização de caracteres da anatomia foliar e a análise da micromorfologia de sementes. Esses autores apresentam chaves geral e regional para a identificação das categorias infra-genéricas, além da subdivisão do gênero Begonia em 63 seções. Neste trabalho, cada seção seria restrita a um continente em particular. Muitas seções e espécies ocorriam na Ásia e na América, algumas espécies na África e nenhuma na Austrália, todavia, a circunscrição e a classificação de tais seções continuaram controversas, uma vez que o gênero apresenta um número grande de seções, muitas delas excessivamente baseadas na distribuição geográfica e outras sem um 
consenso na delimitação, o que torna a classificação totalmente questionável; por exemplo, as cápsulas triloculares com placentas partidas seriam as únicas características compartilhadas pelos membros americanos da seção Knesbeckia (Klotzsch) A. DC., no entanto, essas características também eram encontradas em 33 outras seções de Begonia.

A importância das categorias infra-genéricas para os diferentes autores é variável, por exemplo, Smith \& Schubert (1941), na revisão das espécies da Argentina, posicionaram as nove espécies de Begonia em seções e apresentaram chaves de identificação tanto para as espécies quanto para as seções. Smith \& Wasshausen (1986), na flora do Equador, posicionaram as espécies do gênero Begonia em seções, no entanto, Smith et al. (1986) já não posicionam o gênero Begonia em seções e o mesmo verifica-se no trabalho de Golding \& Wasshausen (2002). Nestes trabalhos, Smith et al. (1986) e Golding \& Wasshausen (2002) publicaram chaves para identificação das espécies de Begoniaceae com uma lista de todos os binômios conhecidos desta família. Além disso, estes autores incluíram ilustrações, pranchas ou fotos, geralmente do material tipo. Tais publicações possuem um inestimável valor como referência nomenclatural e para a identificação das espécies de Begoniaceae.

Jacques (2002), no estudo taxonômico das espécies brasileiras do gênero Begonia L. (Begoniaceae) com placenta partida, verificou que grupos tradicionalmente tratados como seções não são sustentados como monofiléticos, portanto, a classificação infragenérica é artificial. E mesmo na hipótese de os táxons polifiléticos e parafiléticos serem abolidos da classificação taxonômica, de acordo com a autora, o gênero não deveria ser tratado ao nível seccional, então, faz-se necessário um rearranjo das seções, uma vez que a organização das mesmas permanece indefinida.

Utilizando dados de sequencias de DNA, recentes esforços (Swensen et al. 2001; Tebbitt et al. 2001; Forrest \& Hollingsworth, 2003; Plana, 2003 Forrest et al. 2005) têm focado na reconstrução da filogenia de Begonia. O gênero Symbegonia Warb. que incluía 12 espécies endêmicas da Nova Guiné, tradicionalmente distinguido de Begonia somente pelas flores pistiladas com perianto conado e pelas sépalas e pétalas livres das flores estaminadas, foi incluído em Begonia para que este gênero se tornasse monofilético (Forrest \& Hollingsworth, 2003).

Por conseguinte, o presente estudo contribui com o conhecimento da flora do Estado de Minas Gerais, sobretudo do gênero Begonia L. 


\section{OBJETIVOS}

O presente trabalho teve como objetivos principais:

$\checkmark$ Realizar o levantamento e o estudo taxonômico das espécies de Begoniaceae que ocorrem no Estado de Minas Gerais, apresentando descrições, chave de identificação, mapas de distribuição geográfica, ilustrações e comentários;

$\checkmark$ Analisar os materiais de Begoniaceae dos principais herbários com coleções da flora de Minas Gerais, atualizando assim as identificações;

$\checkmark$ Mapear a ocorrência das espécies de Begonia L. no Estado de Minas Gerais;

$\checkmark$ Delimitar morfologicamente as espécies de Begonia L. que ocorrem em Minas Gerais. 


\section{MATERIAL E MÉTODOS}

\subsection{A área de estudo:}

O Estado de Minas Gerais é formado por 853 municípios (GeoMINAS, 2009) e ocupa uma área de aproximadamente $588.384 \mathrm{~km}^{2}$, o que corresponde a cerca de $7 \%$ do território nacional (Costa et al., 1998).

$O$ relevo é bastante variado $e$, em algumas regiões, fortemente acidentado, destacando-se elevações expressivas como a serra da Mantiqueira (na divisa com os Estados de São Paulo e Rio de Janeiro), a Cadeia do Espinhaço (na porção central do Estado, direção norte-sul) e a serra do Caparaó (na divisa com o Estado do Espírito Santo), onde se eleva o Pico da Bandeira com 2.890m alt., ponto culminante do Estado (Costa et al., 1998).

As diferentes formas de relevo somadas às especificidades de solo e clima proporcionaram paisagens muito variadas, estas recobertas por vegetações características. Sendo assim, é possivel entender a ocorrência de vegetações tão distintas em ambientes semelhantes do ponto de vista topográfico e climático, mas com características locais particulares (Martins, 2000).

No quadro fitofisionômico de Minas Gerais, destacam-se duas grandes unidades: a área de cerrado, englobando toda a porção centro-ocidental e fragmentos de Mata Atlântica ocupando a porção leste-sudoeste. Além destas, ao norte ocorrem expansões da caatinga (fig. 01, pág. 07). As formações campestres (campo limpo e campo rupestre) aparecem nas áreas serranas $e$ as comunidades hidromórficas (veredas e campos de várzeas) ocorrem em menor escala (Martins, 2000).

De acordo com a classificação de Veloso et al. (1991), o Estado de Minas Gerais compreende diferentes formações florestais: a floresta estacional semidecidual (floresta tropical subcaducifólia), ocupa grande parte do território; a formação estacional baixo-montana está restrita a uma pequena área no vale do rio Doce, na divisa com o Espírito Santo; a floresta ombrófila mista (floresta de araucária), apresenta-se em pequenas manchas, como disjunções florísticas da Serra da Mantiqueira; a floresta ombrófila densa (floresta pluvial tropical - Mata Atlântica) ocorre em pequenas manchas no lado mineiro do maciço do Itatiaia (Almeida, 1996; Fontes, 1997) e as matas ciliares ou de galeria são encontradas em todas as regiões do Estado, recebendo influência florística dos tipos vegetais adjacentes (Silva, 2000).

Nas regiões do Alto e Médio Jequitinhonha, Alto e Médio São Francisco, Campo das Vertentes, Zona Metalúrgica, Triângulo Mineiro e Alto Paranaíba, encontram-se as áreas de cerrado formadas por um relevo plano ou suavemente ondulado. Incluem-se aí as formações florestais (cerradão, mata seca, mata ciliar), savânicas (cerrado stricto sensu, parque de cerrado e vereda) e campestres (campo sujo, campo limpo e campo rupestre) (Brandão, 2000).

Em Minas Gerais os campos rupestres estão normalmente circundados pelo cerrado (Giulietti et al., 1997). Na mesma altitude podem ocorrer florestas de galeria ao longo dos rios, cerrados e florestas de altitude (pluvio-nebulares). Uma continuidade maior de serras encontra-se ao longo da Cadeia do Espinhaço, onde se estabelece um 
rico mosaico de comunidades sob controle da topografia local, da natureza, do substrato e do micro clima (Menezes \& Giulietti, 2000).

A caatinga mineira ocupa uma área relativamente pequena no Estado e apresenta tipologia diversificada conforme sua posição no relevo e as suas condições edáficas locais. É representada pela sua formação típica, suas variações e disjunções, com fisionomias que vão do arbóreo ao arbustivo, abertas ou densas e outras muito específicas, tais como furados e as vazantes (Kuhlmann et al., 1994).

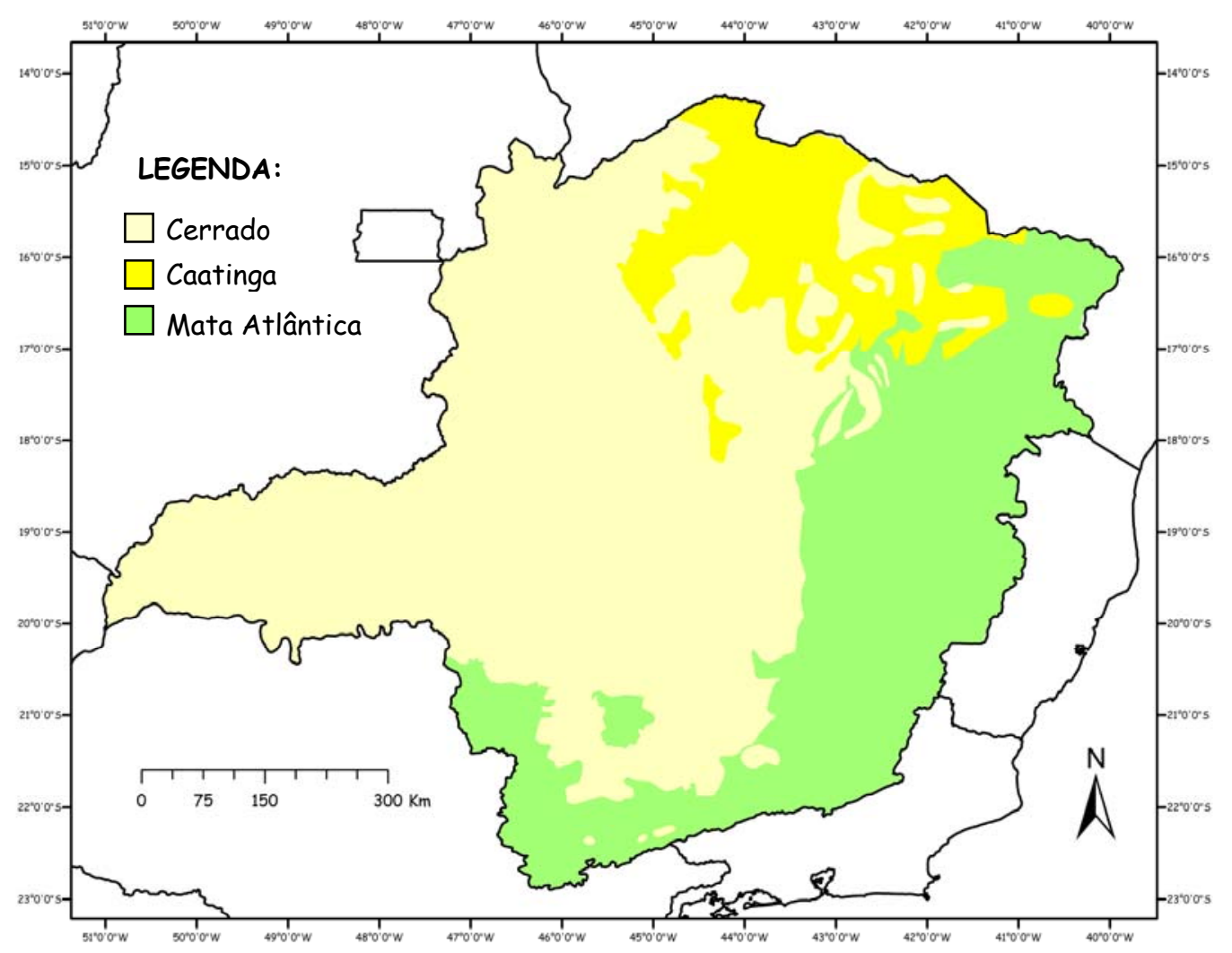

Figura 01: Biomas de Minas Gerais, adaptado de GeoMINAS (2009).

\subsection{Expedições de coleta:}

Foram realizadas expedições de coleta dirigidas prioritariamente a localidades para as quais havia registros de espécies pouco coletadas ou mal conhecidas. Tais expedições tiveram como objetivos ampliar o número de exemplares de Begoniaceae para as análises e observar as espécies em seus ambientes naturais, ilustrando-as através de fotos e, registrando assim, as variações populacionais. Os materiais coletados durante as expedições estão depositados no herbário ESA, com duplicatas enviadas aos herbários SPF e BHCB. O roteiro que reuniu esses materiais está apresentado a seguir:

20-27/II/2007: MG/Santana do Riacho - complexo da Serra do Cipó;

01-04/X/2007: MG/São Roque de Minas - complexo da Serra da Canastra;

17-19/I/2008: MG/Conceição do Ibitipoca - complexo do Parque Estadual do Ibitipoca; 
20-27/III/2008: MG/Alto Caparaó - complexo do Parque Nacional do Caparaó; MG/Araponga - complexo do Parque Estadual da Serra do Brigadeiro; MG/Carangola Fazenda Santa Rita, MG/Passa Quatro; MG/Itamonte - complexo do Parque Nacional do Itatiaia.

\subsection{Levantamento bibliográfico:}

O levantamento bibliográfico baseou-se em consultas a obras específicas sobre Begoniaceae (floras e monografias), descrições originais e buscas em sites especializados (W3Tropicos e International Plant Names Index) e àqueles que disponibilizam obras históricas online (Botanicus e Bibliothèque Nationale de France).

\subsection{Consulta aos herbários:}

Para a elaboração do trabalho foram consultados os principais herbários brasileiros com coleções significativas da flora de Minas Gerais, através de solicitação de empréstimos ou de visitas pessoais. Tais materiais serviram de base para a elaboração das descrições e ilustrações das espécies, para a obtenção de dados sobre floração, frutificação e distribuição geográfica. Os herbários cujas coleções foram examinadas estão listados a seguir (acrônimos de acordo com Holmgren et al., 1990):

BHCB - Universidade Federal de Minas Gerais - Belo Horizonte/MG;

CESJ - Universidade Federal de Juiz de Fora - Juiz de Fora/MG;

ESA - Escola Superior de Agricultura "Luiz de Queiroz" - Piracicaba/SP;

ESAL - Universidade Federal de Lavras - Lavras/MG;

GFJP - Universidade do Estado de Minas Gerais - Carangola/MG;

HB - Herbarium Bradeanum - Rio de Janeiro/RJ;

HUFU - Universidade Federal de Uberlândia - Uberlândia/MG;

MBM - Museu Botânico Municipal de Curitiba / Curitiba-PR;

OUPR - Universidade Federal de Ouro Preto - Ouro Preto/MG:

PAMG - Empresa de Pesquisa Agropecuária de Minas Gerais (EPAMIG) - Belo Horizonte/MG;

RB - Jardim Botânico do Rio de Janeiro - Rio de Janeiro/RJ;

SP - Instituto de Botânica - São Paulo/SP:

SPF - Universidade de São Paulo - São Paulo/SP;

UEC - Universidade Estadual de Campinas - Campinas/SP;

VIC - Universidade Federal de Viçosa - Viçosa/MG.

\subsection{Estudo Taxonômico:}

Para cada espécie estudada foram elaboradas descrições baseadas nos materiais herborizados e apresentados comentários taxonômicos e sobre distribuição geográfica 
(incluindo mapas), floração, frutificação e ilustrações (pranchas a nanquim e/ou fotografias). Das estruturas analisadas foram obtidas as medidas máximas e mínimas, sendo as medidas muito fora do usual apresentadas em parênteses.

A seqüência de apresentação das espécies segue a ordem alfabética e os materiais examinados estão apresentados de acordo com a sequência sugerida pela Flora Neotropica. Ao final do trabalho, é fornecida uma lista de exsicatas analisadas, em ordem alfabética de coletores, assim como uma lista dos nomes científicos. Na tentativa de completar as descrições, as informações entre colchetes foram extraídas da literatura (monografias sobre Begoniaceae), devido algumas espécies possuírem um número reduzido de materiais disponíveis para o presente estudo.

A análise de estruturas de tamanhos reduzidos, tais como tricomas e peças florais, foi feita através do uso de um estereomicroscópio Olympus SZH10 com câmara clara acoplada para a elaboração das ilustrações. As flores foram ilustradas após serem reidratadas e dissecadas, cobertas com plástico adesivo e devolvidas às exsicatas correspondentes, permitindo análises futuras sem a necessidade de destacar novas flores.

Para elaboração dos mapas de distribuição geográfica das espécies utilizou-se o programa ArcGis 9.1 (Environmental System Research Institute, Inc. - ESRI) e a base de dados Basemap of the Americas (Flora Neotropica). As coordenadas geográficas para a plotagem nos mapas foram obtidas a partir das próprias etiquetas das exsicatas, ou então a partir de índices de localidades online como Global Gazeteer (http://www.fallingrain.com/world) ou IBGE (http://www.ibge.org.br).

A terminologia morfológica condiz com as definições de Font-Quer (1953), Hickey (1973), Rafdford et al. (1974), Payne (1978), Weberling (1989) e Harris \& Harris (2001). Alguns termos adotados estão de acordo com a terminologia empregada em publicações referentes às Begoniaceae, como os trabalhos de Smith et al. (1986), Golding \& Wasshausen (2002), dentre outros. As abreviações das obras históricas foram padronizadas de acordo com Stafleu \& Cowan (1976-1988), as dos periódicos, de acordo com o Catálogo Coletivo Nacional de Publicações Seriadas (CCN, 2009), complementado por Lawrence et al. (1968). A autoria dos táxons foi abreviada segundo Brumitt \& Powell (1992) e as sinonímias das espécies estão de acordo com Golding \& Wasshausen (2002) e Jacques (2002).

Informações adicionais acerca do método e alguns termos morfológicos utilizados no presente estudo estão listados abaixo:

\section{A) FOLHAS:}

As medidas de comprimento de lâmina em folhas actinódromas e caspedódromas foram direcionadas à maior nervura somada ao comprimento do lobo basal, que por sua vez foi mensurado através da linha de projeção da nervura sobre o lobo (fig 02-A, pág.11) e em folhas peninérveas essas medidas correspondem à nervura principal. Em folhas palmatissectas, as medidas de comprimento e largura e a descrição da nervação, correspondem aos segmentos medianos e não à lâmina total.

De Candolle (1861), Smith \& Smith (1971), Burt-Utley (1986, 1990), Silva (1998), Jacques (2003) utilizaram termos como "oblíqua" e "transversal" para expressarem o 
ângulo formado entre a nervura maior da lâmina foliar e o pecíolo. Embora tais termos sejam subjetivos, foram mantidos devido à dificuldade de definição do formato da lâmina.

\section{B) INFLORESCÊNCIAS E VERTICILOS PROTETORES:}

Há muita discussão em como denominar os verticilos protetores das flores de Begonia. Embora anatomicamente se verifique a presença dos dois verticilos (Doorenbos et. al., 1998), e ainda que nas flores estaminadas seja nítida a distinção dos mesmos, para o presente estudo foi adotado termo "tépalas" devido à difícil distinção do cálice e da corola nas flores pistiladas.

De forma semelhante, a aplicação do termo "profilo" é bastante controversa em Begoniaceae e, assim, para as descrições das espécies do presente estudo, não foi utilizado o termo "profilo", mas sim "brácteas" e "bractéolas" (fig.03, pág.11), de acordo com Roth (1944), Font-Quer (1953) e Weberling (1989).

\section{C) FRUTOS:}

As medidas de largura da ala maior dos frutos foram direcionadas à região mediana locular no início da ala maior e mensuradas através de uma linha horizontal projetada até o ápice da ala (fig.02-B, pág.11). 

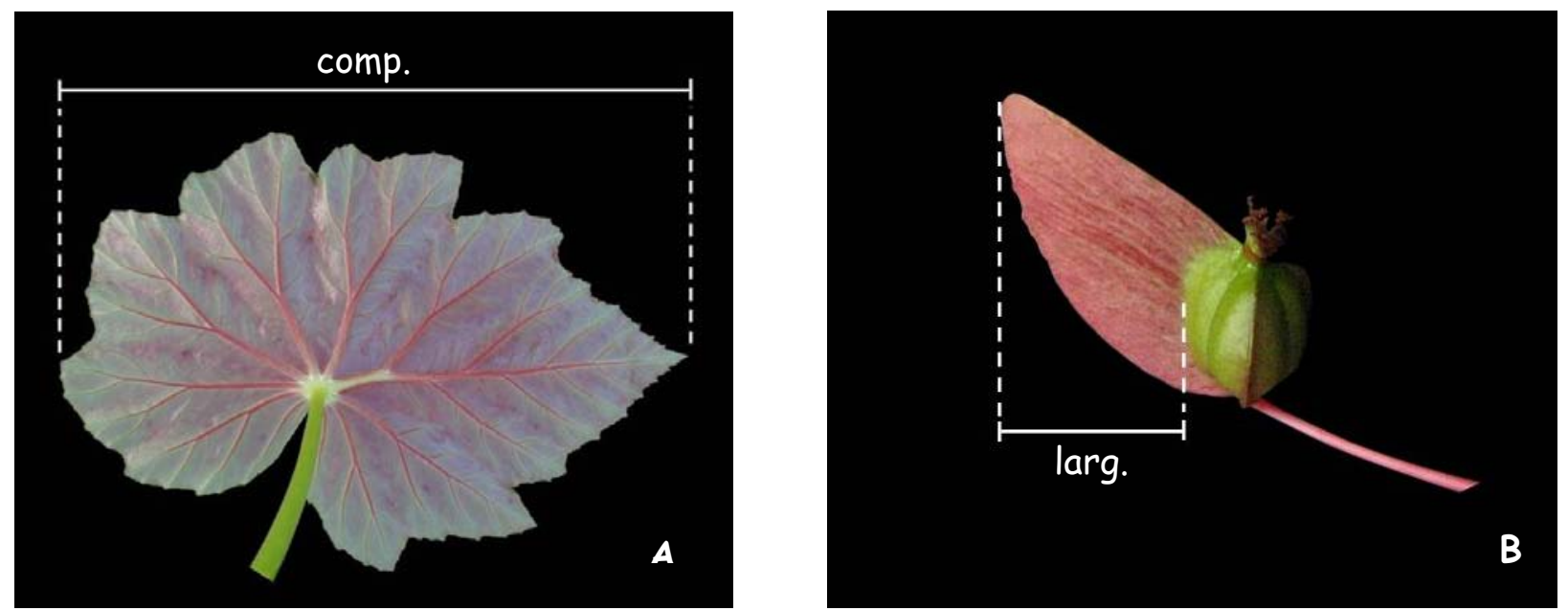

Figura 02: A-Comprimento da folha; B- Largura da ala maior da cápsula.

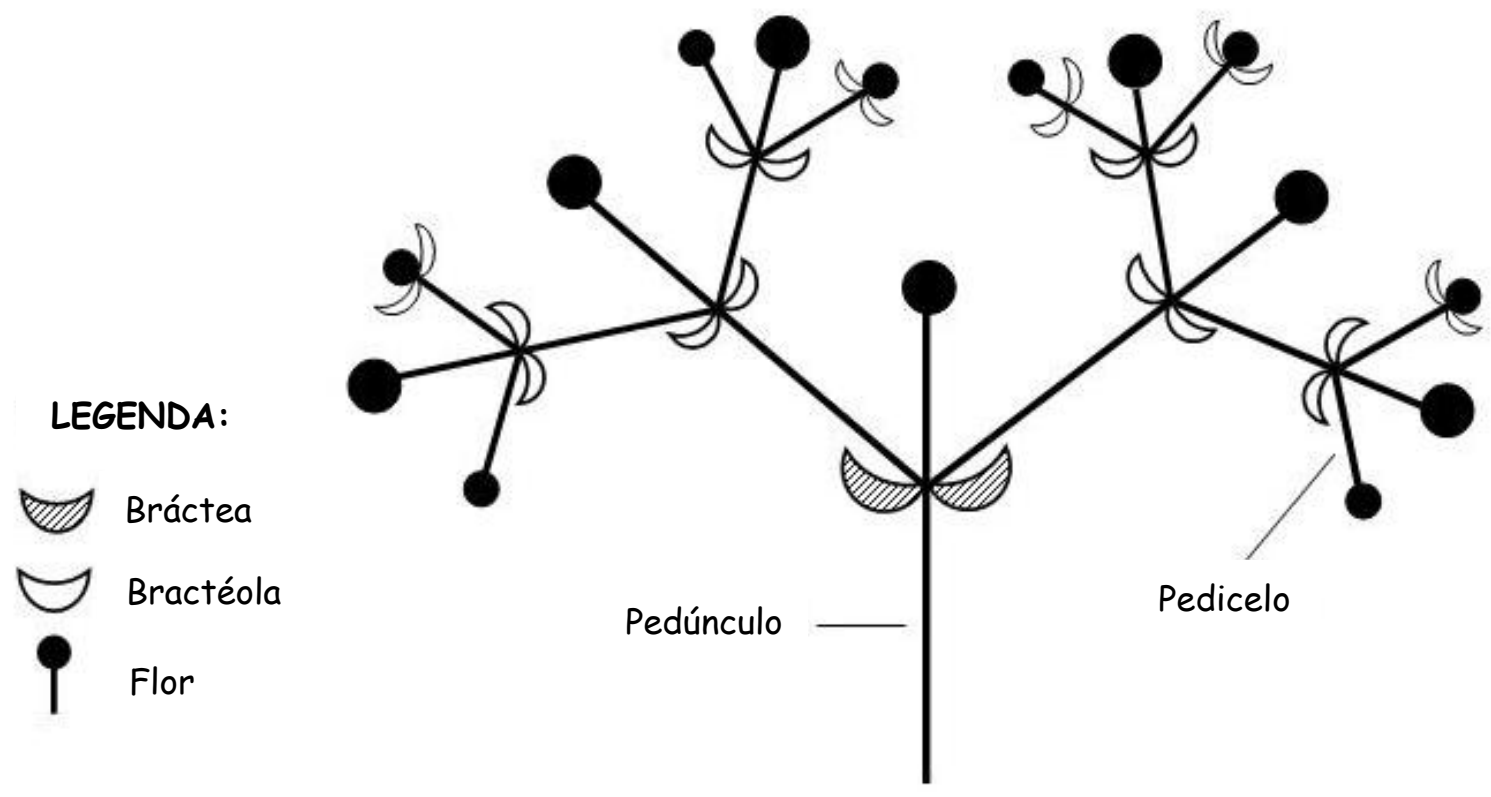

Figura 03: Modelo esquemático das inflorescências de BegoniaL. 


\section{RESULTADOS E DISCUSSÃO}

\subsection{Descrição da família:}

(Baseada em: Gauthier, 1950; Cronquist, 1981; Clement, 2004; Judd et al. 2009).

ERVAS terrestres, geralmente carnosas, às vezes escandentes, epífitas ou hemiepífitas, raramente arbustos. CAULES simples ou bastante ramificados, com nós e entrenós bem definidos, curtos ou longos, ou ainda indistintos, glabros ou com indumento variado. FOLHAS alternas, raramente opostas ou verticiladas, pecioladas, simples ou raramente compostas, inteiras a profundamente partidas, frequentemente lobadas, geralmente assimétricas, com formas e margens variadas, geralmente actinódromas, glabras ou com indumento. ESTÍPULAS livres, persistentes ou caducas, geralmente foliáceas, glabras ou com indumento. INFLORESCÊNCIAS cimosas, axilares, pouco ou muito ramificadas, unissexuadas ou bissexuadas. FLORES vistosas, diclinas, pediceladas, actinomorfas ou assimétricas, prefloração imbricada, tépalas petalóides, livres ou conadas, com colorações alva, rósea ou vermelha. BRÁCTEAS geralmente dispostas aos pares, geralmente vistosas, persistentes ou caducas. FLORES ESTAMINADAS: tépalas 2 ou 4, neste caso dispostas em dois verticilos (2 externas maiores e 2 internas menores). ANDROCEU formado por 4 a numerosos estames, originados em sequência centrípeta, com filetes livres ou às vezes unidos na base, anteras rimosas ou poricidas. FLORES PISTILADAS: tépalas 2-6, mais frequentemente 5. GINECEU 2-5 carpelar formado por um ovário ínfero ou semi-ínfero, 2-5 locular (mais frequentemente 3-locular); hipanto com alas dorsais desenvolvidas, iguais ou diferentes entre si; placentação axilar ou parietal, placenta íntegra ou bipartida, óvulos numerosos e bitegumentados; estiletes em número igual ao dos carpelos, livres ou unidos na base, bífidos no ápice formando dois ramos espiralados ou não, com superfície estigmática papilosa. FRUTO cápsula loculicida com rompimento basal ou apical, com 3-alas iguais ou diferentes entre si, raramente baga. SEMENTES numerosas, com testa ornamentada e com pouco endosperma.

\subsection{Descrição do gênero Begonia:}

(Baseada em: Gauthier, 1950; Cronquist, 1981; Forrest \& Hollingsworth, 2003; Forrest, 2005).

FOLHAS inteiras a profundamente partidas, frequentemente lobadas, geralmente assimétricas, com formas e margens variadas. FLORES ESTAMINADAS: tépalas 2 ou 4, neste caso dispostas em dois verticilos (2 externas maiores e 2 internas menores). PISTILADAS: tépalas mais frequentemente 5. GINECEU formado por um ovário ínfero, placentação axilar. FRUTO cápsula loculicida com rompimento basal, 3-alas. SEMENTES formadas por opérculo, células do colar e células da testa. 
4.3. Chave para as espécies de Begonia L. que ocorrem no Estado de Minas Gerais:

1. Lâmina peltada

2. Caules glabros, estípulas triangulares de margem irregular, glabras

Begonia sp.(pág.125)

2. Caules hirsutos, geralmente com um aglomerado de estípulas e escamas na base, estípulas elípticas de margem inteira a levemente ondulada, com tricomas no dorso

B. paulensis (pág. 98)

1. Lâmina basifixa

3. Lâminas palmatissectas

4. Segmentos com margem atingindo o ponto a partir de onde irradiam as nervuras, não deixando as mesmas expostas, segmentos com bases atenuadas

B. Iuxurians (pág.84)

4. Segmentos com margem não atingindo o ponto a partir de onde irradiam as nervuras, deixando as mesmas expostas, segmentos com bases agudas

5. Segmentos com margem dentado-serreada

B. incisoserrata (pág.78)

5. Segmentos com margem irregularmente serreada

B. digitata (pág.50)

3. Lâminas inteiras ou lobadas

6. Lâminas palmatífidas 7

7. Incisões superficiais, lâminas transversais, reniformis, bractéolas de ambas as flores persistentes e triangulares

B. reniformis (pág.104)

7. Incisões profundas, mas não ultrapassando a metade da distância entre a margem $e$ o ponto de irradiação das nervuras, bractéolas de ambas as flores tardiamente caducas

8. Lâminas transversais, depresso ovaladas, bractéolas de ambas as flores triangulares, glabras

B. gardneri (pág.60)

8. Lâminas transversais, largamente elípticas, bractéolas de ambas as flores elípticas a ovais, tomentosas

B. platanifolia (pág.102)

6. Lâminas não palmatífidas 9

9. Estípulas caducas ou tardiamente caducas 10

10. Lâminas 3-5lobadas 
11. Lobo terminal triangular com ápice acuminado, os demais ou pelo menos um deles, largamente oval(is) com ápice(s) arredondado(s) a obtuso(s)

B. rufa (pág.111)

11. Lobo terminal triangular ou lanceolado com ápice acuminado a agudo, os demais triangulares ou lanceolados com ápices agudos ou acuminados

12. Lobos triangulares com ápices acuminados, raramente agudos, bractéolas de ambas as flores ovais

B. apparicioi (pág.33)

12. Lobos lanceolados com ápices agudos a acuminados, bractéolas de ambas as flores lanceoladas

B. altamiroi (pág.20)

10. Lâminas inteiras a levemente lobadas

13. Plantas com caules glabros 14

13. Plantas com caules revestidos

14. Lâminas com margem dentado-serreada (4-6dentado), estípulas tardiamente caducas, brácteas e bractéolas de ambas as flores lanceoladas, persistentes

B. convolvulacea (pág.36)

14. Lâminas com margem inteira ou levemente ondulada

15. Plantas terrestres, robustas, lâminas elípticas, estípulas ovais com ápice acuminado

B. maculata (pág.86)

15. Plantas hemiepífitas, lâminas ovais a largamente ovais a cordiformes, estípulas triangulares a ovais com ápice mucronulado, filetes unidos na base, anteras poricidas terminais

B. integerrima (pág.80)

16. Venação peninérvea, lâminas de base assimétrica, lâminas oblongas a elípticas

B. heringeri (pág.67)

16. Venação actinódroma, lâminas de base cordada

17. Estípulas triangulares

17. Estípulas lanceoladas ou ovais-oblongas

18. Cápsulas com alas desenvolvidas, semelhantes entre si, indumento tomentoso, formado por tricomas estrelados, lâminas largamente elípticas a largamente ovais, flores estaminadas com 2 tépalas

B. grisea (pág.64)

18. Cápsulas com alas desenvolvidas, diferentes entre si

19. Plantas glabriúsculas, tricomas simples muito esparsos acima dos nós mais jovens dos caules e sob as nervuras principais na face abaxial das folhas, e tricomas glandulares muito esparsos nas tépalas das flores pistiladas e nas alas das cápsulas, lâminas ovais a largamente ovais, ápice acuminado, margem irregularmente denteada, flores pistiladas com 5 tépalas 
19. Plantas escabrosas, indumento formado por tricomas simples, curtos de base larga, tricomas finos e por escamas, lâminas reniformes, levemente lobada, ápices agudos, margem irregularmente ondulada a irregularmente crenada, flores pistiladas com 4 tépalas

B. hugelii (pág.74)

20. Plantas delicadas, vilosas, tricomas simples, lâminas cordiformes a largamente obovais, com ápice agudo, cápsulas com alas desenvolvidas, diferentes entre si, sendo a ala maior bastante ascendente com ápice agudo

B. fischeri (pág.52) 20. Plantas robustas, laxamente pustulosas, indumento formado por pequenas escamas, às vezes achatadas, e por tricomas simples mais tricomas estrelados, estes muito esparsos, lâminas reniformes, levemente lobada, ápice acuminado

B. neocomensium (pág.92)

9. Estípulas persistentes

21. Plantas com caule com indumento 22

21. Plantas com caule glabro 26

22. Indumento aracnóide ou pubérulos 23

22. Indumento viloso, piloso ou pubescente 24

23. Indumento aracnóide, estípulas ovais com ápice aristado a mucronado, lâminas oblíquas, elípticas a ovais, margem inteira a irregularmente ondulada

B. moysesii (pág.90)

23. Indumento não aracnóide, estípulas lanceoladas a estreitamente elípticas com ápice mucronulado, lâminas oblíquas, ovais-lanceoladas, margem dentado-serreada

B. angulata (pág.27)

24. Lâminas ovais, estípulas elípticas a ovais, com margem fimbriada, cápsulas com alas desenvolvidas, diferentes entre si, sendo a ala maior levemente ascendente com ápice arredondado a obtuso

B. hirtella (pág.72)

24. Lâminas elípticas a largamente elípticas ou reniformes,

estípulas triangulares

25. Lâminas com margem dentado-serreada, ciliada, base cordada, estípulas com margem laciniada, venação actinódroma, flores estaminadas com 4 tépalas, glabras, tépalas, estiletes e bractéolas persistentes nas cápsulas

B. alchemilloides (pág.17)

25. Lâminas com margem irregularmente serreada, ciliada, base assimétrica, estípulas com margem inteira, venação caspedódroma, flores estaminadas com 2 tépalas, pubescentes a vilosas no dorso, estiletes persistentes, tépalas e bractéolas caducos nas cápsulas

B. ulmifolia (pág.119)

26. Pecíolos completamente glabros

26. Pecíolos revestidos ou com um colar de tricomas no ápice 
27. Estípulas reflexas, caules angulosos, lâmina oblíquas, ovais-lanceoladas, tépalas externas das flores estaminadas, às vezes, com uma dobra ou um apêndice carnoso no dorso

B. angularis (pág.24)

27. Estípulas apressas, caules cilíndricos, estriados 28

28. Lâminas cuculadas, venação actinódroma, estípulas oblongas a ovais, cápsulas com alas desenvolvidas, diferentes entre si, sendo a ala maio levemente ascendente com ápice obtuso a agudo

B. cucullata (pág.41)

28. Lâminas elípticas a ovais, venação peninérvea, estípulas triangulares a lanceoladas de margem inteira, cápsulas com alas pouco desenvolvidas ou rudimentares, plantas trepadeiras ou escandentes B. fruticosa (pág.58)

29. Estípulas com ápice retuso, obovais a oblongas, pecíolos lanosos, lâminas oblíquas a transversais, ovais B. curtii (pág.45) 29. Estípulas com ápice agudo ou acuminado, pecíolos glabros, com um colar de tricomas no ápice

30. Lâminas 4-5(-6)lobadas, com ápices agudos a acuminados, estípulas triangulares, bractéolas de ambas as flores triangulares, tardiamente caducas

B. riedelii (pág.109)

30. Lâminas inteiras a levemente lobadas, com ápice agudo a acuminado, lobo basal arredondado, estípulas ovais a oblongo-lanceoladas, bractéolas de ambas as flores lanceoladas, persistentes B. valdensium (pág.121) 


\subsection{Descrições das espécies:}

4.4.1. Begonia alchemilloides Meissner ex. A. DC., Ann. Sci. Nat., Bot., IV, $11: 125,1859$.

Begonia leptophylla Taub. in Engl., Bot. Jahrb. Syst., 21:445, 1896.

(PRANCHA: fig.06: A-G, pág.23; MAPA: fig.04, pág.22)

ERVAS delicadas, pilosas, tricomas simples, 3-30 cm alt. CAULES 0,1-0,4cm diâm., decumbentes a estoloníferos, suculentos, estriados, pouco ramificados, verdes a avermelhados, glabrescentes; entrenós $0,4-3(-3,5) \mathrm{cm}$ comp. ESTÍPULAS $0,5-0,7 \mathrm{~cm}$ comp., 0,1-0,4cm larg., triangulares, ápice acuminado, base truncada, margem laciniada, membranáceas, persistentes, apressas, glabras. FOLHAS com pecíolos 0,9-4,5(-5,5)cm comp., estriados, glabrescentes; lâminas 1,5-3,3cm comp., 2-4,5cm larg., inteiras, basifixas, membranáceas, transversais a oblíquas, largamente elípticas a reniformes, levemente assimétricas, ápice arredondado, geralmente não distinto, base cordada, margem dentada a serreada, ciliada, esparsamente pilosas em ambas as faces, geralmente 0 indumento é distribuído mais densamente na face adaxial, verdes em ambas as faces, venação actinódroma, 5-8 nervuras na base. CIMEIRAS 2-6 flores, 1-2 nós; pedúnculos 1,5-4cm comp., glabrescentes; brácteas 1-3 pares, raramente 4 pares, 1$4 \mathrm{~mm}$ comp., 1-2mm larg., elípticas a estreitamente elípticas, largamente ovais a largamente obovais, ápice acuminado, base truncada, margem laciniada, persistentes, glabras. FLORES ESTAMINADAS tépalas 4, as externas $0,6-0,8 \mathrm{~cm}$ comp., 0,3-0,5cm larg., obovais, ápice arredondado, base truncada, margem inteira, glabras, as internas 0,5-0,7cm comp., $2 \mathrm{~mm}$ larg., elípticas, ápice arredondado, base aguda, margem inteira, glabras, alvas a róseas; pedicelos 0,4-0,5cm comp., glabros; bractéolas 2-3 pares, 0,2$0,4 \mathrm{~cm}$ comp., 0,1-0,2cm larg., lanceoladas, ápice acuminado, base truncada, margem laciniada, persistentes, glabras; estames 5-10, ca. 3mm comp., filetes unidos na base; anteras ca. $2 \mathrm{~mm}$ comp., rimosas, oblongas. FLORES PISTILADAS tépalas 5 , semelhantes entre si, 0,4-0,7cm comp., 0,1-0,2cm larg., elípticas, ápice agudo, base truncada, margem inteira, glabras, alvas a róseas; pedicelos 0,5-1,5cm comp., glabros; bractéolas 2-3 pares, 0,2-0,4cm comp., 0,1-0,2cm larg., obovais a lanceoladas, ápice acuminado, base truncada, margem laciniada, inseridas no pedicelo, logo abaixo do hipanto, persistentes, glabras, estiletes 0,2-0,4cm comp.; estigmas ca. $1 \mathrm{~mm}$ comp., ramos cilíndricos e espiralados; hipanto glabro. CÁPSULAS 0,4-0,6cm comp., 1-1,3cm larg., tépalas, estiletes e bractéolas persistentes, região locular 0,4-0,6cm diâm., placentas partidas; alas diferentes entre si, sendo a ala maior ascendente; ala maior 0,3-0,5cm larg., ápice obtuso; alas menores 0,1-0,3cm larg. SEMENTES oblongas.

DISTRIBUIÇÃO E HÁBITATS: Begonia alchemilloides é uma planta umbrófila, encontrada no Vale do Rio Doce, na região Central de Minas Gerais e Metropolitana de Belo Horizonte, nas Vertentes, Sul de Minas e Alto São Francisco, em áreas dominadas por campos rupestres, matas de galeria, afloramentos rochosos, chapadões; em locais com 
vegetação arbustiva mais densa, em sombras de capoeiras, cangas, em grotas úmidas, em cavidades ou fendas de rochas, entre ou em baixo de pedras úmidas.

FLORAÇÃO E FRUTIFICAÇÃO: floresce e frutifica de janeiro a maio e em outubro.

COMENTÁRIOS: Begonia alchemilloides é uma espécie bastante característica por apresentar estípulas de margem laciniada e caules geralmente estoloníferos. No material herborizado a lâmina é hialina.

Esta espécie é morfologicamente semelhante à Begonia hoehneana Irmsch. e podem ser prontamente diferenciadas pelo fato desta última apresentar estípulas com margem ciliado-dentada e pela ala maior das cápsulas com ápice agudo, além da distribuição geográfica restrita ao Estado de São Paulo. Smith et al. (1986) diferenciam estas duas espécies pelos caules eretos em Begonia alchemilloides e caules reptantes ou escandentes em Begonia hoehneana. Entretanto, observou-se aqui que Begonia alchemilloides pode apresentar caules reptantes ou escandentes.

Begonia alchemilloides também apresenta similaridades morfológicas com Begonia fischeri Schrank e Begonia hirtella Link, diferenciando-se destas espécies, principalmente, pelas características apresentadas na tabela I a seguir:

Tabela I: Características diagnósticas entre Begonia alchemilloides, Begonia fischerie Begonia hirtella.

\begin{tabular}{|c|c|c|c|}
\hline & B. alchemilloides & B. fischeri & B. hirtella \\
\hline Forma das folhas & $\begin{array}{c}\text { largamente elípticas } \\
\text { a } \\
\text { reniformes }\end{array}$ & $\begin{array}{c}\text { cordiformes } \\
\text { a } \\
\text { largamente obovais }\end{array}$ & ovais \\
\hline Ápice das folhas & geralmente não distinto & agudo & agudo \\
\hline Estipulas & $\begin{array}{l}\text { triangulares } \\
\text { com margem } \\
\text { laciniada }\end{array}$ & $\begin{array}{l}\text { lanceoladas } \\
\text { com margem } \\
\text { fimbriada }\end{array}$ & $\begin{array}{l}\text { elípticas a ovais } \\
\text { com margem } \\
\text { fimbriada }\end{array}$ \\
\hline Ala maior da cápsula & $\begin{array}{l}\text { ascendente } \\
\text { com } \\
\text { ápice obtuso }\end{array}$ & $\begin{array}{c}\text { bastante ascendente } \\
\text { com } \\
\text { ápice agudo }\end{array}$ & $\begin{array}{c}\text { levemente ascendente } \\
\text { com } \\
\text { ápice obtuso }\end{array}$ \\
\hline Sementes & oblongas & estreitamente elípticas & oblongas \\
\hline
\end{tabular}

MATERIAL EXAMINADO: BRASIL. MINAS GeraIs. Belo Horizonte, Arredores de Belo Horizonte. Rodovia Rio, 5.VII.1960, Heringer, E.P. s.n., (HB 13800); Serra do Curral., 29.III.1942, Magalhães, M. 3345, (RB). Caeté, Serra da Piedade - Ladeira com afloramentos rochosos, 14.V.90, Arbo, M.M. 4081, et al. (SPF). Catas Altas, 23.II.1944, Black 2131-B, (ESAL); 23.II.1944, Black, G. 2131b, (RB); Serra da Mutuca., VI.1945, Williams, L.B. 7273, (HB). Delfinópolis, Estrada para a Casinha Branca - Condomínio de Pedras, 12.III.2003, Pacheco, R.A. 517, et al. (HUFU); Condomínio de Pedras., 17.V.2003, Pacheco, R.A. 601, et al. (HUFU); Estrada para Casa Branca, Fazenda Paraíso, Sete Cidades., 10.IX.2002, Romero, R. 6280, et al. (HUFU); Trilha para a cachoeira do Alpinista., 16.V.2003, Romero, R. 6901, et al. (HUFU); Condomínio das Pedras - Parque Nacional da Serra da Canastra., 28.XI.2003, Romero, R. 7007, et al. (HUFU). Itabirito, Pico do Itabirito. Serra dos Inconfidentes, 17.II.1995, Teixeira, W.A. s.n. (SP 277267). Lavras, 5.I.1945, Black, G. 2131, (RB). Nova Lima, Serra do Curral, perto de Belo 
Horizonte, 29.IV.1945, Williams, L.O. 6746, \& Assis, V. (RB); "Vargem de Ouro Podre", Serra da Mutuca, 3.VI.1945, Williams, L.0. 7273, \& Assis, V. (RB). Pitangui, 24.XI.1944, Black 2542-B (ESAL). São Roque de Minas, Serra da Canastra - Parque Nacional da Serra da Canastra Chapadão acima da Casca d'Anta, 4.I.1983, Farney, C. 217 (RB); Parque Nacional da Serra da Canastra - Estrada para a cahoeira Casca d'Anta, 20.II.2002, Mazine, F.F. 402, et al. (ESA); Estrada para a cahoeira Casca d'Anta, Parque Nacional da Serra da Canastra., 20.III.1995, Nakajima, J.N. 933, et al. (ESA); Cidade de Pedra. Sete Cidades - Parque Nacional da Serra da Canastra, 29.I.2002, Romero, R. 6222A (HUFU); Parque Nacional da Serra da Canastra. Entre Piumhi e Araxá, ca. 70 km de Piumhi, 21.II.1978, Shepherd, G.J. 7155 et al. (UEC). 
4.4.2. Begonia altamiroi Brade, Arq. Jard. Bot. Rio de Janeiro, 8:230, pl. 4, 1948. Tipo: Brasil: Espírito Santo. Município de Itaguassu - Santa Maria, Brade 18400 et al., V/1943 (Holótipo: RB!, Isótipos: RB!).

(PRANCHA: fig.06: H-K, pág.23; MAPA: fig.05, pág.22)

ERVAS robustas, tomentosas, tricomas simples, 0,4-2m alt. CAULES 0,4-1cm diâm., eretos, subcarnosos, cilíndricos, estriados, ramificados, verdes a marrons, laxamente tomentosos; entrenós (1,5-)3-6cm. ESTÍPULAS 0,9-2cm comp., 0,3-0,5cm larg., lanceoladas, ápice mucronulado, base truncada, margem inteira a levemente ondulada, membranáceas, caducas, apressas, carinadas, carinas tomentosas. FOLHAS com pecíolos 4,5-12,5cm comp., cilíndricos, estriados, tomentosos, glabrescentes; lâminas (9-)11-20cm comp., (4-)6-9cm larg., 3-4(-5)lobadas, basifixas, papiráceas, transversais, todos os lobos lanceolados, assimétricas, lobo terminal com ápice acuminado, os demais com ápices agudos a acuminados, base cordada, margem irregularmente serrilhada, tomentosas em ambas as faces, sendo o indumento mais concentrado sob as nervuras, em ambas as faces e na face abaxial, face adaxial verde, faca abaxial verde a avermelhada, venação actinódroma, 3-4(-5) nervuras na base. CIMEIRAS 50-80 flores, 4-5 nós; pedúnculos (4-)5,5-19cm comp., glabrescentes; brácteas 1 par, ca. 3mm comp., aprox. $1 \mathrm{~mm}$ larg., triangulares, ápice mucronulado, base truncada, margem inteira a levemente ondulada, caducas, glabrescentes. FLORES ESTAMINADAS tépalas 4, as externas aprox. $8 \mathrm{~mm}$ comp., 6-7mm larg., obovais, ápice obtuso, base arredondada, margem inteira a levemente ondulada, esparsamente tomentosas, tricomas simples, as internas ca. $6 \mathrm{~mm}$ comp., aprox. $2 \mathrm{~mm}$ larg., elípticas, ápice obtuso, base aguda, margem levemente ondulada, glabras, alvas a róseas; pedicelos $0,61 \mathrm{~cm}$ comp., tomentosos; bractéolas 1-4 pares, ca. 3mm comp., aprox. $1 \mathrm{~mm}$ larg., lanceoladas, ápice agudo, base truncada, margem levemente ondulada, caducas, carinadas, carinas tomentosas; estames 20-30, ca. 3mm comp., filetes livres; anteras $1-2 \mathrm{~mm}$ comp., rimosas, oblongas. FLORES PISTILADAS não vistas. CÁPSULAS $5-8 \mathrm{~mm}$ comp., 0,8-1,3cm larg., estiletes persistentes, tépalas e bractéolas caducos, região locular 4-6mm diâm., placentas inteiras; alas diferentes entre si, sendo a ala maior levemente ascendente; ala maior 7 $8 \mathrm{~mm}$ larg., ápice arredondado; alas menores 1-2 mm larg. SEMENTES oblongas.

DISTRIBUIÇÃO E HÁBITATS: Begonia altamiroi é uma espécie xerófila encontrada na Zona da Mata e no Sul de Minas Gerais, nos domínios dos campos rupestres e campos de altitude, em clareiras de matas ou próximas à borda e em áreas perturbadas.

FLORAÇÃo E FRUTIFICAÇÃo: floresce nos meses de fevereiro, março, maio e julho e frutifica em outubro.

COMENTÁRIOS: Begonia altamiroi é uma erva robusta caracterizada principalmente pelos lobos lanceolados e pelo indumento tomentoso, este compartilhado por Begonia apparicioi Brade e por Begonia rufa Thunb. Morfologicamente, estas três espécies são bastante semelhantes, diferenciando-se pela forma dos lobos das folhas. Segundo Smith et al. (1986), em Begonia altamiroi todos os lobos, ou pelo menos o lobo terminal, são oblongos; 
em Begonia rufa, pelo menos um dos lobos é arredondado e em Begonia apparicioi os lobos são triangulares e agudos. Além da forma dos lobos das folhas, outras características diagnósticas dessas três espécies estão apresentadas na tabela XI, pág.112.

De acordo com a descrição original, além da forma da lâmina, Begonia altamiroi pode ser prontamente diferenciada de Begonia apparicioi por apresentar estípulas pequenas e caducas, inflorescências menores que as folhas e pela presença do indumento nas tépalas externas das flores estaminadas, no entanto, tais características não foram observadas no material examinado sendo, portanto, inconsistentes na separação dessas duas espécies. Com relação às dimensões das estípulas, observou-se sobreposições: 0,9$2 \mathrm{~cm}$ comp. / 0,3-0,5cm larg. em Begonia altamiroi e em Begonia apparicioi 1,3-2cm comp. 1 0,3-0,5cm larg. Além disso, em todos os materiais examinados de ambas as espécies, verificou-se estípulas decíduas. O tamanho das inflorescências em relação à dimensão foliar também não é uma característica consistente para a separação dessas espécies, devido à grande plasticidade foliar observada nos dois táxons. Quanto às tépalas externas das flores estaminadas, o indumento está presente no dorso de ambas as espécies, esparso em Begonia altamiroi e um pouco mais compacto em Begonia apparicioi.

MATERIAL EXAMINADO: BRASIL. MINAS GeRAIS. Araponga, Serra da Araponga - Fazenda Neblina, área perturbada, 25.V.1994, Leoni, L.S. 2563 (SP). Fervedouro, Parque Estadual da Serra do Brigadeiro, 10.VII.1999, Lombardi, J.A. 3098 (BHCB). Lima Duarte, Parque Estadual do Ibitipoca. Próxima ao alojamento, 18.I.2008, Delfini, C. 60, \& Tsuji, R. (ESA); Parque Florestal da Serra do Ibitipoca., 24.III.1977, Krieger, L. 77-294, et al. (VIC). São Tomé das Letras, Serra de São Tomé (campo rupestre), 30.X.1984, Cordeiro, I. s.n., et al. (SPF 35111); Sem município, Arredores de Minas Gerais, 28.II.1975, Hatschbach, G. 36564, et al. (SPF, RB).

MATERIAL ADICIONAL EXAMINADO: BRASIL. Espírito SANTO. Itaguassu. Santa Maria, 23.V.1943, Brade, A.C. 18400 et al. (RB). 


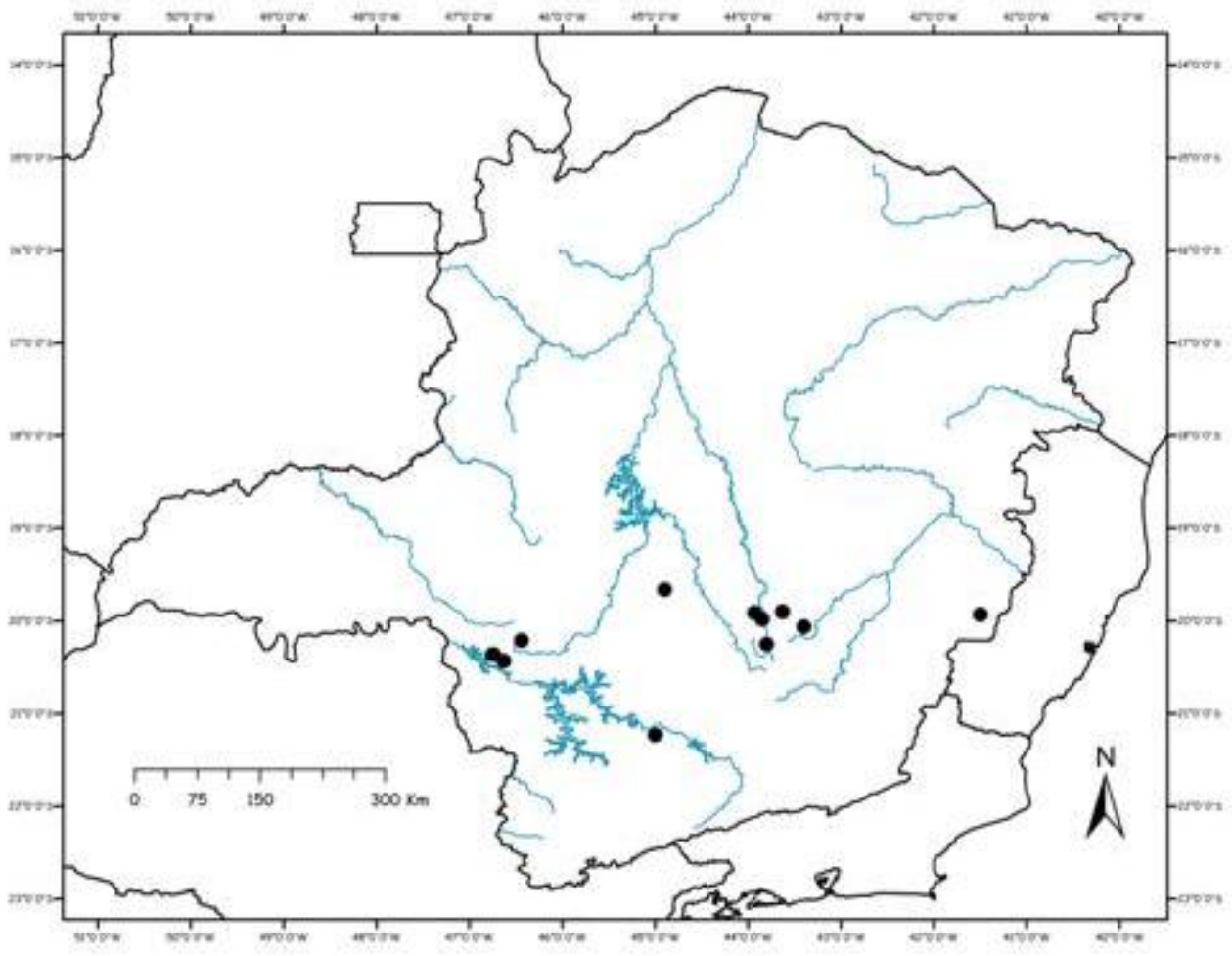

Figura 04: Mapa de distribuição geográfica de B. alchemilloides

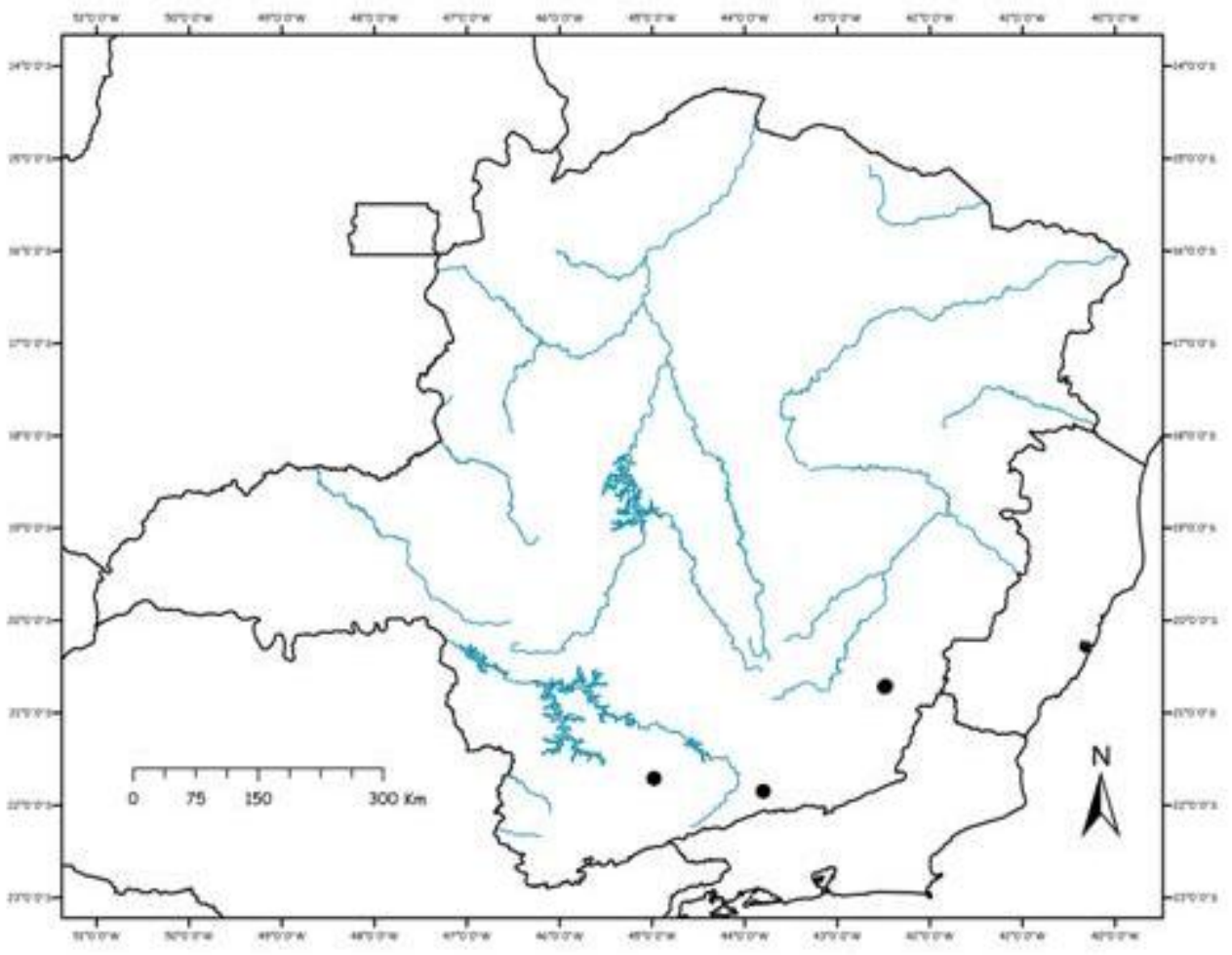

Figura 05: Mapa de distribuição geográfica de B. altomiroi 

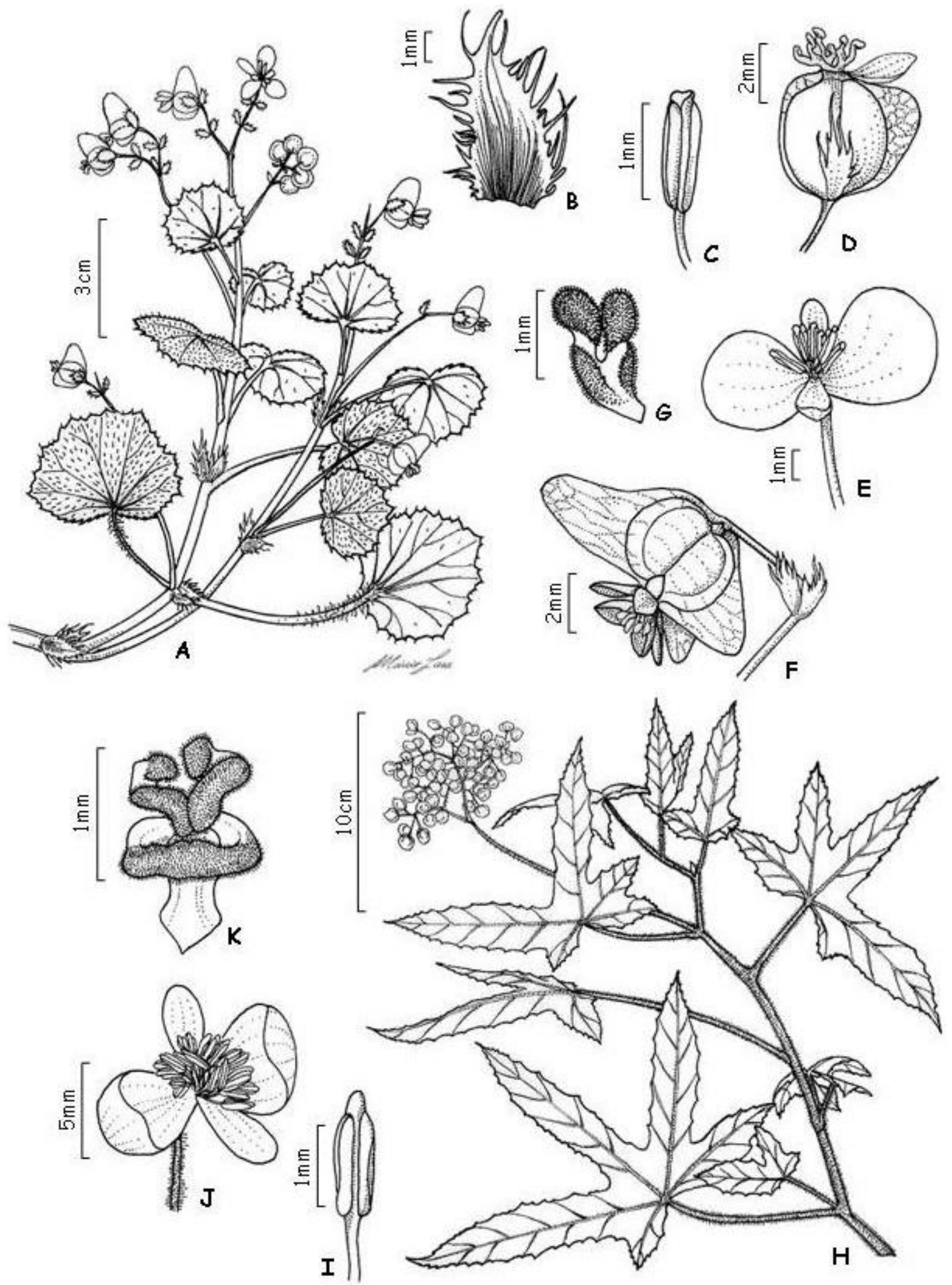

Figura 06: A-G: B. alchemilloides: A- hábito; B- estípula; C-estame; D- cápsula; E- flor estaminada; F- flor pistilada; G- estigma. H-K: $\boldsymbol{B}$. altamiro; $\mathbf{H}-$ hábito; I- estame; Jflor estaminada; K- estigma. [A: J.N. Nakajima, 933 et al (ESA); B: R. Romero, 6222A (HUFU); C-G: R.A. Pacheco, 510 et al (HUFU). H-J: J.A. Lombardi, 3098 (BHCB); K: M.P. Coons, 77-290 et al. (VIC)]. 
4.4.3. Begonia angularis Raddi, Mem. Mat. Fis. Soc. Ital. Sci. Modena, 18:407, 1820.

Begonia hastata Vell., FI. flum., icon., 10:pl. 54, "1827" 1831.

Pritzelia zebrina Klotzsch, Monatsber. Königl. Preuss. Akad. Wiss. Berlin, :126, 1854, nomen nudum.

Begonia zebrina hort. angl. ex Klotzsch, Monatsber. Königl. Preuss. Akad. Wiss. Berlin, :126, 1854, pro syn.

Begonia crenulata Schott ex A. DC., in Martius, FI. bras., 4(1)358, 1861.

(PRANCHA: fig.09: A-F, pág.31; MAPA: fig.07, pág.30; FotOs: fig.10: A-B, pág.32)

ERVAS, glabras, 0,3-1,8m alt. CAULES 0,3-0,7cm diâm., eretos a escandentes, suculentos, angulosos, simples ou pouco ramificados, verdes, glabros; entrenós (0,7-)1,5$6(-11,5) \mathrm{cm}$ comp. ESTÍPULAS $(0,6-) 1,2-3,5(-4,7) \mathrm{cm}$ comp., 0,5-1,5(-3)cm larg., triangulares, ápice mucronulado, base truncada, margem inteira a ligeiramente ondulada, as vezes ciliada, membranáceas, persistentes, reflexas, glabras ou com tricomas na nervura mediana dorsal. FOLHAS com pecíolos 1,5-9(-12) cm comp., angulosos, glabros; lâminas 8-17,5(-22)cm comp., 2-4(-8,4)cm larg., inteiras, basifixas, papiráceas, oblíquas, ovais-lanceoladas, assimétricas, ápice acuminado, base cordada, margem ondulada a serreada, esparsamente ciliada, glabras em ambas as faces, face adaxial verde, face abaxial verde a avermelhada, venação actinódroma, 4-7 nervuras na base. CIMEIRAS 50-200 flores, 5-7 nós; pedúnculos 8,5-13,2(-20)cm comp., glabrescente, tricomas simples; brácteas 1 par, 0,8-1,2cm comp., 0,2-0,6cm larg., elípticas, lanceoladas ou triangulares, ápice mucronulado, base truncada, margem inteira, caducas, glabras. FLORES ESTAMINADAS tépalas 4, as externas 0,4-0,7cm comp., 0,4-0,6cm larg., ovais a largamente ovais, ápice obtuso, base arredondada a corada, margem inteira, glabras, as vezes com uma dobra ou um apêndice carnoso no dorso, as internas 0,4-0,6cm comp., 0,1$0,6 \mathrm{~cm}$ larg., obovadas, ápice obtuso a arredondado, base aguda, margem inteira, glabras, alvas a levemente róseas; pedicelos 0,3-0,8cm comp., glabros; bractéolas 1-2 pares, 2$4 \mathrm{~mm}$ comp., ca. $1 \mathrm{~mm}$ larg., estreitamente elípticas, ápice mucronulado, base truncada, margem inteira, ciliada, posteriormente glabra, caducas, glabras; estames 15-20, ca. $3 \mathrm{~mm}$ comp., filetes levemente unidos na base; anteras $2-3 \mathrm{~mm}$ comp., rimosas, oblongas. FLORES PISTILADAS tépalas 5, uma delas ligeiramente desigual no tamanho e forma, 0,3-0,6cm comp., 0,2-0,4cm larg., elípticas a obovadas, ápice obtuso, base truncada a arredondada, margem inteira, glabras, alvas a levemente róseas; pedicelos 0,5-1,1(1,5) cm comp., glabros; bractéolas 1-2 pares, 3-4(-6) $\mathrm{mm}$ comp., 1(-3) mm larg., estreitamente elípticas, ápice mucronulado, base truncada, margem inteira, inseridas no pedicelo, caducas, glabras; estiletes ca. $1 \mathrm{~mm}$ comp.; estigmas ca. $1 \mathrm{~mm}$ comp., ramos cilíndricos e espiralados, hipanto glabro. CÁPSULAS 0,6-1,1(-1,6)cm comp., 0,5-1,5(-2)cm larg., estiletes persistentes, tépalas e bractéolas caducas; região locular $0,3-0,7 \mathrm{~cm}$ diâm., placentas inteiras, alas diferentes entre si, sendo a ala maior ligeiramente ascendente; ala maior 0,4-1cm larg., ápice obtuso a agudo; alas menores 0,1-0,5cm larg. SEMENTES oblongas. 
DISTRIBUIÇÃO E HÁBITATS: Begonia angularis é uma erva semi-heliófila, encontrada no Vale do Rio Doce, Zona da Mata, nas regiões Central e Sul, Metropolitana de Belo Horizonte, no Vale do Paranaíba, Alto São Francisco e no Vale do Jequitinhonha, preferencialmente em áreas dominadas pela Mata Atlântica e por campos rupestres; em clareiras úmidas próxima a córregos, em bordas de matas, em áreas perturbadas, em barrancos, em formações de arenito, em solos arenosos, entre rochas, sobre pedras e em sub-bosques.

FLORAÇÃO E FRUTIFICAÇÃO: floresce de janeiro a agosto e frutifica praticamente o ano todo.

COMENTÁRIOS: Begonia angularis apresenta como características únicas entre as espécies de Minas Gerais os caules e pecíolos angulosos e as estípulas reflexas.

São reconhecidas duas variedades para Begonia angularis. B. angularis var. angularis é caracterizada principalmente pela menor largura da lâmina foliar e pela ausência do apêndice carnoso no dorso das tépalas externas das flores estaminadas. Outras características importantes para a identificação desta variedade são o porte menor e a presença de indumento no dorso das estípulas e das tépalas externas das flores estaminadas. Já B. angularis var. angustifolia A. DC. caracteriza-se principalmente por apresentar uma dobra ou apêndice carnoso no dorso nas tépalas externas das flores estaminadas (fig.10: B, pág.32), além do porte mais robusto e ausência do indumento no dorso das estípulas e das tépalas externas das flores estaminadas. Entretanto, observações de campo revelaram que estas características (porte, dimensões das folhas e a presença de indumento no dorso das estípulas e das tépalas externas das flores estaminadas) podem ser mutáveis em ambas as variedades e a análise das coleções examinadas mostrou grandes variações das mesmas, o que foi relacionado, então, à plasticidade fenotípica das populações estudadas.

Begonia angularis possui o hábito similar a Begonia angulata Vell. e Begonia valdensium A. DC. As características diagnósticas dessas três espécies estão apresentadas na tabela II, pág.28. Além dessas características, Smith, et al. (1986) separam Begonia angularis de Begonia angulata pela forma da metade apical da lâmina foliar, sendo arredondada a subaguda com ápice acuminado em Begonia angularis e triangular em Begonia angulata.

MATERIAL EXAMINADO: BRASIL. MINAS GeraIs. Alto Caparaó, Caparaó - Parque Nacional Vale Verde - ao lado do córrego, 5.IV.1996, Leoni, L.S. 3276, (GFJP); Vale Verde, 3.IX.1970, Souza, A.B. 106, \& Márcia (RB); Parque Nacional do Caparaó. Estrada entre o alojamento e Vale Verde. Beira do Córrego do Caparaó, 1.IX.1996, Souza, V.C. 12141, et al. (ESA). Baependi, Serra de São Tomé das Letras, 14.VII.1954, Duarte, A.P. 3794, (RB). Caparaó, Parque Nacional do Caparaó. Vale Verde, 15.VI.1991, Hatschbach, G. 55539, et al. (MBM). Carrancas, Serra de Bicas, caminho para cachoeira de Bicas. Mata, 29.IV.1999, Simões, A.O. 794, et al. (UEC). Catas Altas, Serra do Caraça, 18.IV.2005, Mota, R.C. 2893, et al. (BHCB). Caxambu, Parque das Águas, 31.XII.1985, Paciornik, E.F. 214, (BHCB, MBM). Conceição de Ibitipoca, Parque Estadual do Ibitipoca. Mata úmida circundante à Gruta dos Três Arcos, 8.V.2002, Giordiano, L.C. 2472, et al. (RB); Na mata em clareiras úmidas, 15.VI.1979, Krieger, L. 16236, \& Sabino, M. (SPF); 15.VI.1979, Krieger, L. 16236, \& Sabino, M. (MBM). Diamantina, Entrada para a gruta do Salitre e distrito de 
extração, 9.XII.1992, Leitão Filho, H.F. 27621, et al. (HUFU, UEC). Diogo de Vasconcelos, Miguel Rodrigues, 13.X.2000, Carvalho, A.F. 745, (VIC). Espera Feliz, área perturbada ao lado de manancial "Refúgio C. Bicolor", 12.VI.1994, Leoni, L.S. 2585, (SP). Itamonte, estrada para Itamonte. Beira da estrada, 22.III.2008, Delfini, C. 41, \& Paula-Souza, J. (ESA); estrada para Itamonte. Beira da estrada, 22.III.2008, Delfini, C. 43, \& Paula-Souza, J. (ESA); estrada para Itamonte. Beira da estrada, 22.III.2008, Delfini, C. 52, \& Paula-Souza, J. (ESA). Lima Duarte, Parque Estadual do Ibitipoca. Mata (portaria), 22.III.1988, Andrade, P.M. 1127, \& Drumond, M.A. (SP); Parque Estadual do Ibitipoca. Próximo ao alojamento, 18.I.2008, Delfini, C. 55, \& Tsuji, R. (ESA); Parque Estadual do Ibitipoca, mata entre a Gruta do Viajante e a cantina., 10.III.2004, Forzza, R.C. 3129, et al. (RB); Parque Estadual do Ibitipoca. Trilha para a Cachoeirinha. Mata de Grotão, 31.III.2004, Forzza, R.C. 3320, et al. (RB); Parque Estadual do Ibitipoca. Cachoerinha, 31.III.2004, Forzza, R.C. 3333, et al. (RB); Serra de Ibitipoca, Pico do Pião. Formações de Arenito da Série Lavras, 15.V.1970, Sucre, D. 6869, \& Krieger, L. (RB). Nova Lima, Reserva Biológica do Jambeiro, 26.VII.1990, Andrade, P.M. 1396, (BHCB); Serra do Curral, mata fresca, 14.IV.1970, Duarte, A.P. 12767 (RB); APE Fechos - COPASA, 23.II.2001, Sposito 113, \& Versieux, L.M. (BHCB); Serra da Mutuca, perto de Belo Horizonte, em mata, 7.IV.1945, Williams, L.O. 6706, \& Assis, V. (RB). Ouro Preto, s.d., Damazio, L. 1697 (RB). Rio Acima, 14.XII.1997, Vasconcelos, M.F. 40307 (BHCB); 14.XII.1997, Vasconcelos, M.F.O., s.n. (SP 335791). Rio Preto, Gruta do Funil, VII.1989, Grandi, T.S.M. 328, \& Braga, M.M.N. (ESA); Localidade de Funil. Margens do Rio Funil na trilha para o sumidouro. Sopés da Serra Negra (divisa com Lima Duarte). 19,5m da praça central do Rio Preto, na estrada para o Rio do Funil, 26.II.1999, Nic Lughadha, E.M. 235, et al. (SP, ESA). Santa Maria do Salto, Fazenda Duas Barras, 25.VIII.2003, Lombardi, J.A. 5553, et al. (BHCB); Fazenda Duas Barras., 25.VIII.2003, Lombardi, J.A. 5572, et al. (BHCB). Santa Rita de Jacutinga, II.1972, Braga, P.I.S. 2426 (RB). Santa Rita do Sapucaí, Reserva de Santa Rita do Sapucaí, 3.VI.1993, Brandão, M. 22066, \& Araújo, M. (PAMG); 20.VIII.1994, Brandão, M. 24365, (PAMG); 20.VIII.1994, Brandão, M. 24404 (PAMG); Reserva, 15.III.1996, Brandão, M. 24844 (PAMG); Reserva, 15.III.1996, Brandão, M. 24845 (PAMG); Reserva, 30.V.1996, Brandão, M. 24928 (PAMG); Reserva, 15.III.1996, Brandão, M. 24940 (PAMG); Reserva, 22.X.1996, Brandão, M. 27098, (PAMG); Balaio, 11.I.1997, Brandão, M. 27868, (PAMG); Reserva Municipal de Santa Rita do Sapucaí, 20.II.1999, Brandão, M. 28974 (PAMG); Serra da Bela Vista, 20.II.1996, Ribas, O.S. 1324 (MBM); Serra da Bela Vista, 7.VI.1996, Ribas, O.S. 1419 (MBM). São José do Barreiro, Parque Nacional da Serra da Canastra. Acesso pela portaria Casca d'Anta. Trilha para a cachoeira Casca d'Anta, 2.X.2007, Delfini, C. 28, \& Romão, G.O. (ESA). São Roque de Minas, Trilha da Cachoeira Casca d'Anta, Parque Nacional da Serra da Canastra, 20.IV.1997, Nakajima, J.N. 2429, et al. (ESA); Guarita 3, Cachoeira Casca d'Anta, Parque Nacional da Serra da Canastra, 21.III.1995, Romero, R. 2051, et al. (ESA); Trilha da mata parte de baixo da cachoeira Casca d'Anta. Parque Nacional da Serra da Canastra, 21.II.1997, Romero, R. 3937, et al. (ESA). São Tomé das Letras, 20.II.1991, Galvilanes, M.L. 4847, \& Frieiro, F.N.C. (ESAL); Baependi. Na encosta leste da Serra, 20.VI.1962, Mattos, J. 10318, \& Bicalho, H. (SP); 20.II.1991, s.col., s.n. (SP 342701). Sem município, Fazenda de Bocaiúva. Pomba, 10.VI.1947, Heringer, E.P. 2523 (RB); s.d., Saint-Hilaire, A. (HB).

MATERIAL ADICIONAL EXAMINADO: BRASIL. RIO DE JANEIRO. Sem município, Divisa Rio de Janeiro - Minas Gerais, 26.III.2008, Delfini, C. 49, \& Paula-Souza, J. (ESA). 
4.4.4. Begonia angulata Vell., Fl. flum., icon., 10: pl. 52, "1827", 1831.

Begonia reticulata Gardner, London J. Bot., 4: 134, 1845.

Pritzelia angulata Klotzsch ex Wawra, Bot. Ergebn., :51, 1866, pro syn.

(PRANCHA: fig.09: G-L, pág.31; MAPA: fig.08, pág.30)

ERVAS pubérulas, tricomas simples, 0,5-1,5m alt. CAULES 0,3-0,6cm diâm., eretos a escandentes, suculentos, cilíndricos, pouco ramificados, verdes, glabrescentes; entrenós $1-6(-8) \mathrm{cm}$ comp. ESTÍPULAS $0,5-1,5 \mathrm{~cm}$ comp., 0,3-0,9cm larg., lanceoladas a estreitamente elípticas, ápice mucronulado, base truncada, margem inteira, membranáceas, persistentes, apressas, com uma crista de tricomas no dorso, posteriormente glabras. FOLHAS com pecíolos $0,8-3,5(-4,7) \mathrm{cm}$ comp., cilíndricos, com tricomas simples esparsos, estendendo-se pelas nervuras; lâminas $(3-) 4,5-11(11,5) \mathrm{cm}$ comp., 1-3,5(-4,5)cm larg., inteiras, basifixas, membranáceas a papiráceas, oblíquas, oval-lanceoladas, assimétricas, ápice acuminado, base subcordada a cordada, margem dentado-serrilhada, glabrescentes, indumento distribuído mais densamente na face abaxial, face adaxial verde, face abaxial verde a avermelhada, venação actinódroma, 4-6 nervuras na base. CIMEIRAS 50-100 flores, 4-6 nós; pedúnculos (3,5-)4,5-15cm comp., glabrescentes; brácteas 1 par, 1-1,3cm comp., aprox. $5 \mathrm{~mm}$ larg., triangulares, ápice mucronulado, base truncada, margem inteira, caducas, glabras. FLORES ESTAMINADAS tépalas 4, as externas $0,5-1 \mathrm{~cm}$ comp., 0,3-0,8cm larg., ovais a largamente obovais, ápice arredondado a obtuso, base arredondada, margem inteira, glabrescentes, as internas 0,5-0,9cm comp., 0,1-0,4cm larg., elípticas a estreitamente elípticas, ápice arredondado a obtuso, base aguda, margem inteira, glabras, alvas a levemente róseas; pedicelos 0,4-1cm comp., glabros; bractéolas 1-2 pares, ca. de $4 \mathrm{~mm}$ comp., ca. $1 \mathrm{~mm}$ larg., lanceoladas, ápice agudo, base truncada, margem inteira, caducas, glabras; estames 15-25, 3-4mm comp., filetes livres; anteras ca. $2 \mathrm{~mm}$ comp., rimosas, oblongas. FLORES PISTILADAS tépalas 5, uma delas ligeiramente desigual no tamanho e forma, 0,5-0,7cm comp., 0,2-0,7cm larg., ovais a obovais, ápice obtuso, base truncada, margem inteira, glabras, alvas a levemente róseas; pedicelos $0,5-1,5 \mathrm{~cm}$ comp., glabros; bractéolas 1-e pares, ca. de $5 \mathrm{~mm}$ comp., 1-2 mm larg., lanceoladas, ápice agudo, base truncada, margem inteira, inseridas no ápice do pedicelo, caducas, glabras; estiletes 2 $3 \mathrm{~mm}$ comp.; estigmas 1-2mm comp., ramos cilíndricos e espiralados, hipanto glabro. CÁPSULAS 0,8-1,4cm comp., 1,4-1,6cm larg., estiletes persistentes, tépalas e bractéolas caducas; região locular 0,4-1,6cm diâm., placentas inteiras; alas diferentes entre si, sendo a maior levemente ascendente; ala maior 0,8-1cm larg., ápice obtuso a agudo; alas menores $0,1-0,4 \mathrm{~cm}$ larg. SEMENTES elípticas.

DISTRIBUIÇÃo E HÁBITATS: Begonia angulata é encontrada na Zona da Mata e nas regiões central e sul de Minas Gerais, em áreas dominadas pela Mata Atlântica, habitando, então, locais bastante sombrios e úmidos, interiores de matas, barrancos úmidos e escarpas rochosas. 
FLORAÇÃO E FRUTIFICAÇÃO: floresce de janeiro a junho e frutifica nos meses de maio e dezembro.

COMENTÁRIOS: Begonia angulata é uma erva umbrófila bastante característica por apresentar caules e pecíolos cilíndricos, pelos tricomas esparsos nos pecíolos, mais densos no ápice, estendendo-se pelas nervuras e pela margem das folhas dentadoserrilhada.

São reconhecidas três variedades para Begonia angulata baseadas no porte da planta, nas dimensões das folhas, no indumento e no número de flores, sendo elas: $B$. angulata var. angulata, B. angulata var. campos-portoi Brade e B. angulata var. serrana Brade. De acordo com a obra original, B. angulata var. campos-portoi difere da variedade B. angulata var. angulata pelo porte mais robusto, pelas folhas com dimensões menores $e$ pelo indumento nos caules e pecíolos. Já $B$. angulata var. serrana caracteriza-se principalmente pelo indumento hirsuto esparso na região do pecíolo, pelo hábito mais delgado e pelas inflorescências com um número maior de flores. Entretanto, de acordo com a análise dos materiais examinados e das coleções tipo de B. angulata var. camposportoi e B. angulata var. serrana, verificou-se grandes variações destas características, - que foi relacionado, então, à plasticidade fenotípica das populações estudadas.

Begonia angulata possui o hábito semelhante à Begonia angularis e a Begonia valdensium, diferenciando-se destas espécies pelas características apresentadas na tabela II a seguir:

Tabela II: Características diagnósticas entre Begonia angularis, Begonia angulata e Begonia valdensium.

\begin{tabular}{|c|c|c|c|}
\cline { 2 - 4 } \multicolumn{1}{c|}{} & B. angularis & B. angulata & B. valdensium \\
\hline Caules & angulosos & cilíndricos & cilíndricos \\
\hline Pecíolos & glabros & tricomas esparsos & $\begin{array}{c}\text { glabros, com um } \\
\text { colar de tricomas } \\
\text { no ápice }\end{array}$ \\
\hline Margem das folhas & ondulada a serreada & dentado-serrilhada & $\begin{array}{c}\text { irregularmente } \\
\text { crenada a irregularmente } \\
\text { serrilhada }\end{array}$ \\
\hline Estípulas & reflexas & apressas & apressas \\
\hline
\end{tabular}

MATERIAL EXAMINADO: BRASIL. MINAS GeraIs. Antonio Pereira, $11 \mathrm{~km} N$ de Mariana, camino a Santa Bárbara - Colaboração IBUSP, Univ. de São Paulo (SPF). Viagem subsidiada por National Geographic Society, 13.V.1990, Arbo, M.M. 4017, et al. (ESA). Araponga, Fazenda Neblina. Surge no interior da mata de encosta, em área perturbada, em direção ao lageado, ao lado da trilha, 1.II.1992, Leoni, L.S. 1746, (SP). Camanducaia, Monte Verde - Serra da Mantiqueira - Floresta Ombrófila Densa Alto-Montana, 18.III.2001, Meireles. L.D. 6, et al. (UEC); Monte Verde - Serra da Mantiqueira - Floresta Ombrófila Densa Alto-Montana, 13.XII.2001, Meireles. L.D. 834, \& Belinello, R. (UEC); Monte Verde - Serra da Mantiqueira - Floresta Ombrófila Densa AltoMontana, 13.XII.2001, Meireles. L.D. 835, \& Belinello, R. (UEC); Monte Verde - Serra da Mantiqueira - Floresta Ombrófila Densa Alto-Montana, 9.IV.2002, Meireles. L.D. 1014, et al. (UEC); Monte Verde - Serra da Mantiwueira - Floresta Ombrófila Densa Alto-Montana, 
10.IV.2002, Meireles. L.D. 1015, et al. (UEC). Conceição de Ibitipoca, 24.II.1977, Krieger, L. 14620, (MBM). Descoberto, Reserva Biológica da Represa do Gama, 23.III.2002, Forzza, R.C. 2111, et al. (MBM). Engenheiro Passos, Parque Nacional de Itatiaia, descida do Planalto, 22.I.2003, Mansano, V.F. 182, et al. (RB). Lima Duarte, Parque Estadual do Ibitipoca. Mata Grande, 18.I.2008, Delfini, C. 53, \& Tsuji, R. (ESA); Parque Estadual do Ibitipoca, Gruta do Viajante, 10.III.2004, Forzza, R.C. 3109, et al. (RB); Parque Florestal da Serra do Ibitipoc., 24.II.1977, Krieger, L. 77295 et al. (VIC); Serra de Ibitipoca, Pico do Pião. Formações de Arenito da Série Lavras, 13.V.1970, Sucre, D. 6783, \& Krieger, L. (RB); Parque Estadual do Ibitipoca. Mata Grande, 18.I.2005, Temponi, L.G. 393, et al. (RB, SPF). Ouro Preto, Rancharia, 15.V.1979, Barroso 8, \& Ferreira (PAMG). Passa Quatro, E.E.P. Rio Retiro, 3.V.1948, Brade, A.C. 18949, \& Araújo, S. (RB); Sertão dos Martins, 8.V.1948, Brade, A.C. 19072, \& Araújo, S. (RB). Virginha, 20.VI.1987, Hashimoto, G. 503 (MBM).

MATERIAL ADICIONAL EXAMINADO: BRASIL. RIO DE JANEIRO. Rio de Janeiro, Itatiaia, 26.III.1943, Pereira, E 360 (RB). SÃo PAULo. Campos do Jordão, II.1937, Porto, P.C. 3350 (RB).

MATERIAL ADICIONAL EXAMINADO (B. angulata var. campos-portol): BRASIL. SÃo PAULO. Campos do Jordão. 1000m s.n. mar, II.1937, Campos Porto, P. 3350, (Holótipo: RB!, Isótipos: RB!).

MATERIAL ADICIONAL EXAMINADO (B. angulata var. serrana): BRASIL. RIO DE JANEIRO. Município? Serra do Itatiaia entre km 12 e 15, 1200-1600m s.n. mar, 26.III.1943, Pereira, E. 326, (Holótipo: RB!, Parátipos: RB!). 


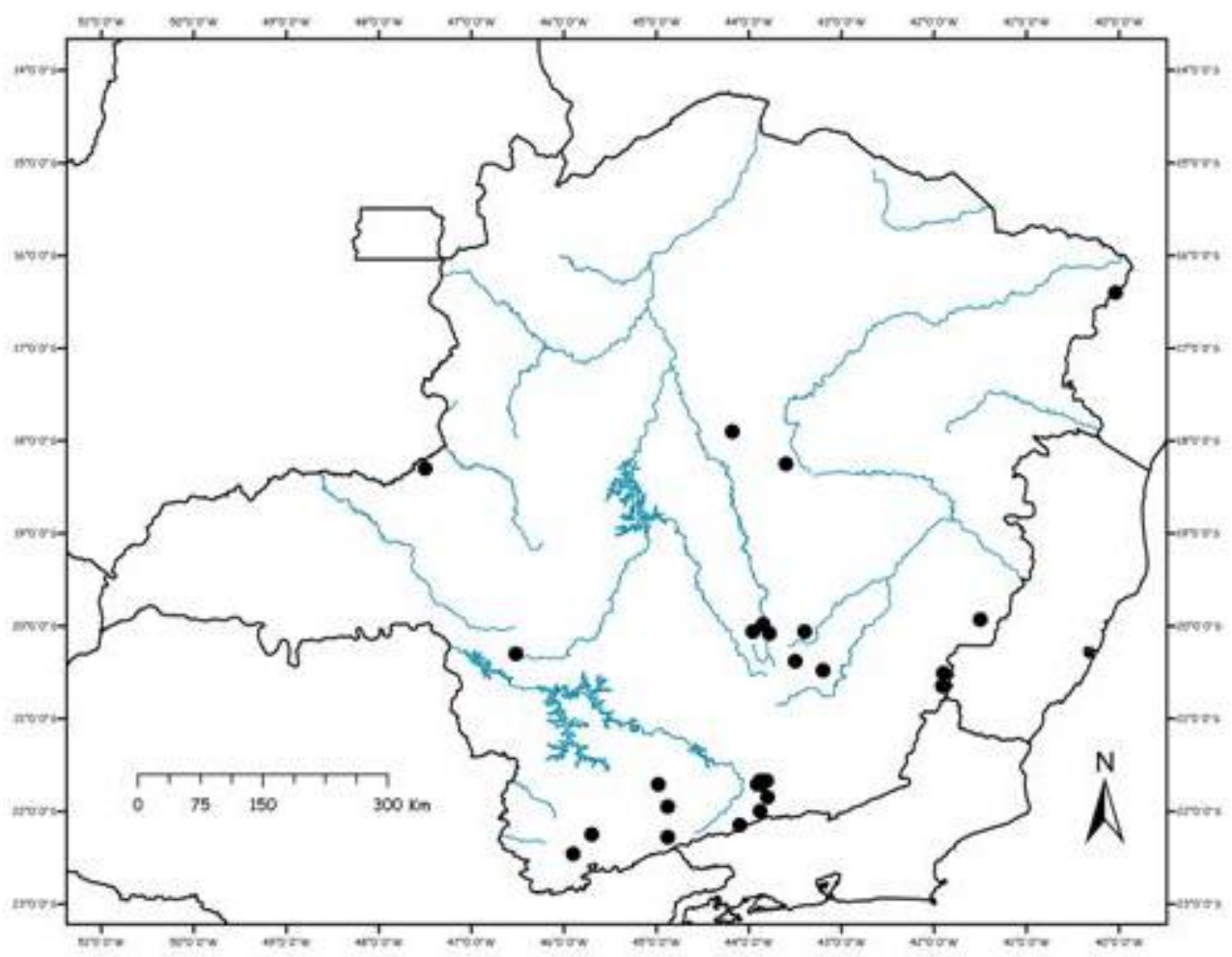

Figura 07: Mapa de distribuição geográfica de B. ongukoris

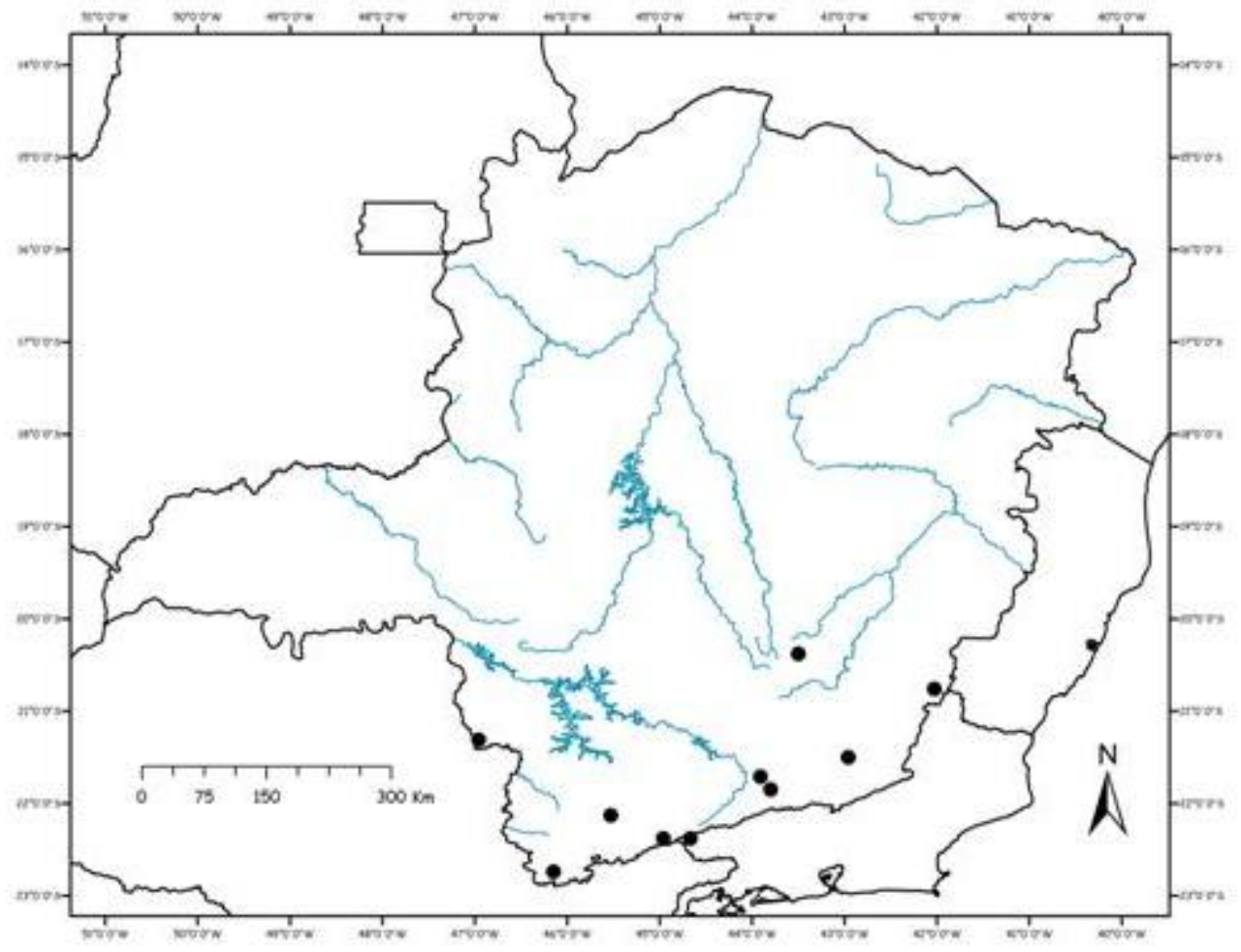

Figura 08: Mapa de distribuição geográfica de B. ongubto 


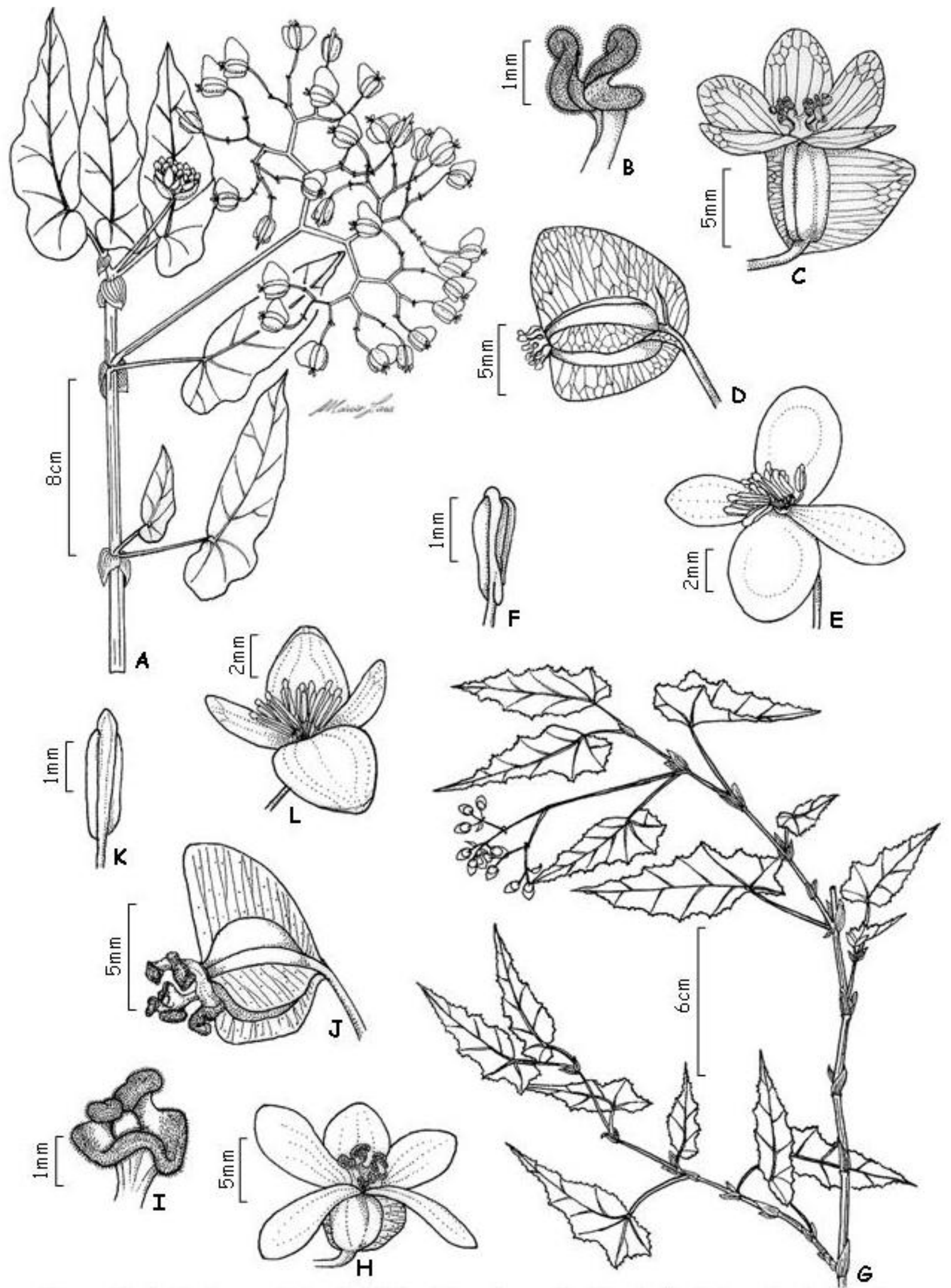

Figuro 09: A-F: $\boldsymbol{B}$. angularis: A- hábito; B- estigma; $\boldsymbol{C}$ - flor pistilada; D- cápsula; E- flor estaminada; F- estame. G-L: $\boldsymbol{B}$. angulata: $\mathbf{G}-$ hábito; H- flor pistilada; I- estigma; Jcápsula; K- estame; L- flor estaminada. [A-C: C. Delfini, 52 \& J. Paula-Souza (ESA); D-F: $C$. Delfini, 43 \& J. Paula-Souza (ESA), G: L.G. Temponi, 393 (RB); H-J: R.C. Forzza, 3109 et al. (RB); K-L: L.S. Leoni, 1746 (SP)]. 


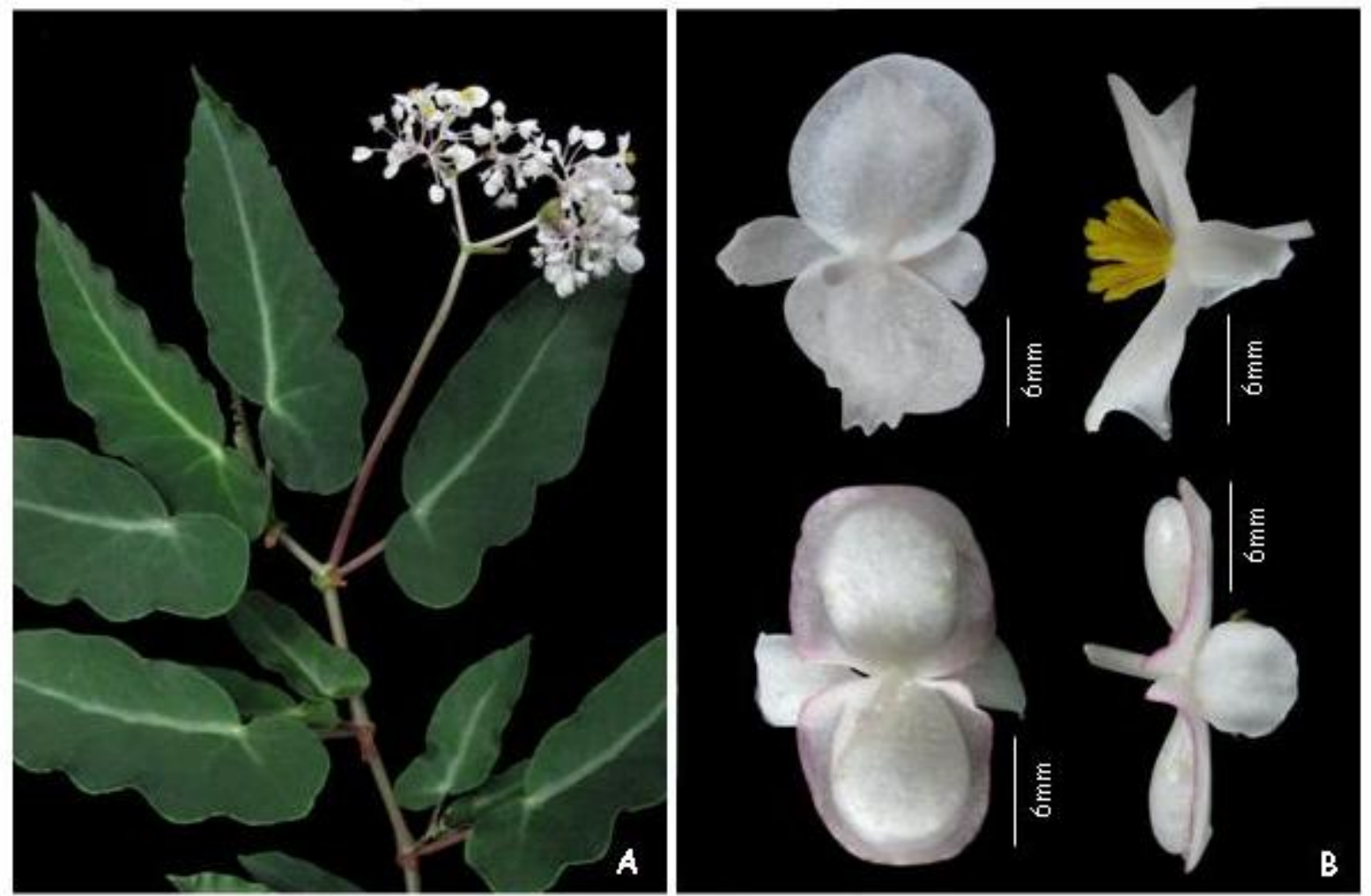

Figura 10: B. onguloris: A- ramo: B- detalhe do apêndice carnoso.
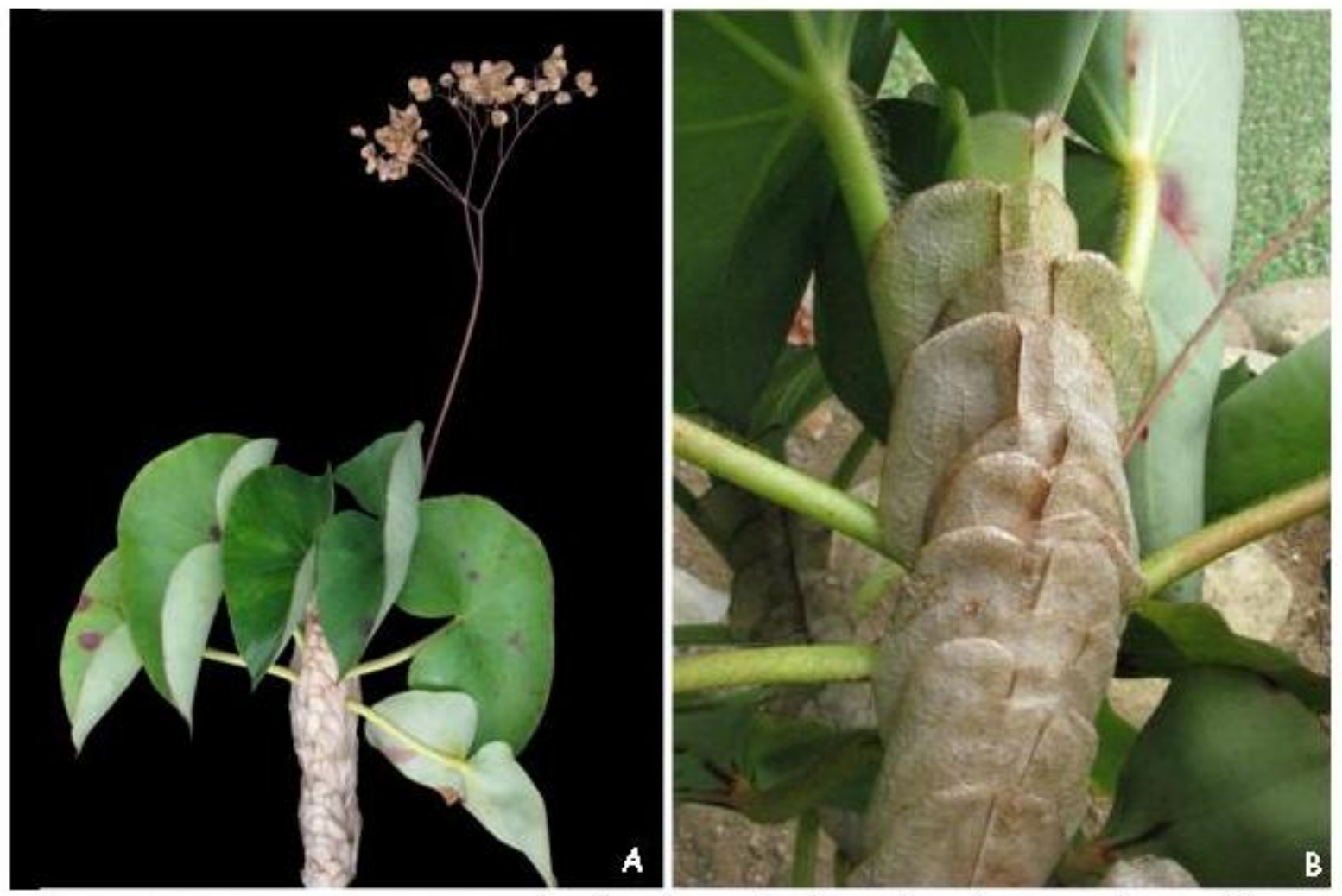

Figura 11: B. curtif. A-ramo; B-detalhe das estípulas e do indumento dos pecíolos. 
4.4.5. Begonia apparicioi Brade, Arq. Jard. Bot. Rio de Janeiro, 8: 229, pl. 3, 1948. Tipo: Brasil: Espírito Santo. Município de Itaguassu - Santa Maria, 1000m, Brade 18387 et al., V/1946 (Holótipo: RB! Isótipos: RB!).

(PRANCHA: fig.14: A-F, pág.40; MAPA: fig.12, pág.39)

ERVAS robustas, tomentosas, tricomas simples, 1-1,5m alt. CAULES 0,5-2cm diâm., eretos, subcarnosos, cilíndricos, estriados, ramificados, verdes a marrons, glabrescentes; entrenós 2-7cm comp. ESTÍPULAS 1,3-2cm comp., 0,3-0,5cm larg., lanceoladas, ápice mucronulado, base truncada, margem inteira a levemente ondulada, membranáceas, caducas, apressas, geralmente carinadas, carinas tomentosas, às vezes completamente revestidas no dorso, glabrescentes. FOLHAS com pecíolos $15-26 \mathrm{~cm}$ comp., cilíndricos, estriados, tomentosos; lâminas 15-26cm comp., 4,5-19cm larg., 4(5)lobadas, basifixas, papiráceas, transversais, lobo terminal e os demais triangulares, lâminas assimétricas, lobo terminal e os demais com ápices frequentemente acuminados, raramente agudos, base cordada, margem serrilhada, tomentosos em ambas as faces, indumento geralmente mais concentrado na face abaxial e sob as nervuras, face adaxial verde, face abaxial verde a avermelhada, venação actinódroma, 4-6 nervuras na base. CIMEIRAS 50-100 flores, 5-6(-7) nós; pedúnculos (4,5-)6-31cm glabrescentes; brácteas 1 par, 4-9mm comp., 3-4mm larg., triangulares, ápice mucronulado, margem inteira a levemente ondulada, caducas, glabrescentes. FLORES ESTAMINADAS tépalas 4, as externas 6-8mm comp., 6-7mm larg., obovais, ápice obtuso a arredondado, base arredondada, margem levemente ondulada, tomentosas, tricomas simples e tricomas glandulares esparsos, as internas 6-7mm comp., 3-4mm larg., elípticas, ápice obtuso, base aguda, margem levemente ondulada, glabras, alvas a róseas; pedicelos $0,5-1 \mathrm{~cm}$ comp., tomentosos, tricomas simples; bractéolas 1-4 pares, ca. $8 \mathrm{~mm}$ comp., aprox. $3 \mathrm{~mm}$ larg., ovais, ápice obtuso, base arredondada, margem ondulada, caducas, laxamente tomentosas; estames 25-30, ca. $4 \mathrm{~mm}$ comp., filetes livres; anteras aprox. $2 \mathrm{~mm}$ comp., rimosas, oblongas. FLORES PISTILADAS tépalas 5, uma delas ligeiramente diferente no tamanho e na forma, 5-8mm comp., 4-6mm larg., ovais a elípticas, ápice obtuso, base atenuada, margem inteira a serreada na metade superior, laxamente tomentosas, alvas a róseas; pedicelos 1-1,5cm comp., tomentosos; bractéolas 1-4 pares, ca. 8mm comp., aprox. 3mm larg., ovais, ápice obtuso, base arredondada, margem ondulada, um par inserido logo abaixo do hipanto e as demais no pedicelo, caducas, laxamente tomentosas; estiletes ca. $4 \mathrm{~mm}$ comp.; estigmas aprox. $2 \mathrm{~mm}$ comp., ramos cilíndricos e espiralados, hipanto glabrescente. CÁPSULAS 0,6-1 cm comp., 1-2,3cm larg., estiletes persistentes, tépalas e bractéolas caducos, região locular 5-8mm comp., placentas inteiras; alas diferentes entre si, sendo a ala maior levemente ascendente; ala maior 0,5-1,5cm larg., ápice arredondado a obtuso; alas menores $0,5-1,5 \mathrm{~mm}$ larg. SEMENTES oblongas a lineares.

DISTRIBUIÇÃO E HÁBITATS: Begonia apparicioi é encontrada em nas regiões central, metropolitana de Belo Horizonte, no Vale do Rio Doce, na Zona da Mara, em Alto São Francisco e sul de Minas Gerais, nos domínios dos campos rupestres ou da Mata 
Atlântica, habitando matas de galerias, matas ciliares, florestas montanas, clareiras e bordas de matas e de capões, solos arenosos-pedregosos, barrancos e fendas de rochas.

FLORAÇÃO E FRUTIFICAÇÃO: floresce nos meses de janeiro e de abril a julho e frutifica em fevereiro, de maio a agosto e em novembro.

COMENTÁRIOS: Begonia apparicioi é uma erva robusta caracterizada principalmente pelos lobos triangulares com ápices frequentemente acuminados e pelo indumento tomentoso, todavia, esta característica é compartilhada também por Begonia altamiroi Brade e por Begonia rufa Thunb. Morfologicamente, estas três espécies são muito semelhantes, diferenciando-se pelas características apresentadas na tabela XI, pág.112 e pela forma dos lobos das folhas, discutido anteriormente em Begonia altamiroi (pág.20). Como foram avaliados somente espécimes de Minas Gerais e nem todos os materiais tipos dos nomes em questão foram vistos, não é possível concluir a respeito de sinonimizações, entretanto, considerando a grande plasticidade das folhas encontrada nos espécimes coletados em Minas Gerais e na coleção tipo de Begonia apparicioi, fica evidente que essa característica é inconsistente e que, provavelmente, não suficiente para sustentá-la como uma espécie distinta de Begonia rufa.

De acordo com a obra original, Begonia apparicioi compartilha com Begonia riedelii A. DC. e Begonia valdensium A. DC. as estípulas persistentes e as brácteas e bractéolas das flores pistiladas grandes e vistosas, distinguindo-se dessas espécies pela forma da lâmina, pelo revestimento e pelo maior comprimento do pedúnculo em comparação com o comprimento da folha, no entanto, nem todas estas características foram confirmadas na análise do material examinado. As estípulas, tanto em Begonia riedelii quanto em Begonia valdensium são persistentes, mas em Begonia altamiroi as estípulas são decíduas. Com relação às dimensões das brácteas e bractéolas das flores pistiladas, nos materiais de Begonia altamiroi foram encontradas brácteas com 4-9mm comp. / 3-4mm larg. e bractéolas com ca. $8 \mathrm{~mm}$ comp. / aprox. 3mm larg.; em Begonia valdensium as brácteas medem 7-12mm comp. / ca. 5-7mm larg. e as bractéolas 5-7mm comp., 1-2mm larg. e em Begonia riedelii, as brácteas medem 1-1,5cm comp./ 0,3-0,5cm larg., no entanto, as bractéolas possuem comprimento bem menor comparado às demais espécies, sendo 3$4 \mathrm{~mm}$ comp. I ca. $2 \mathrm{~mm}$ larg. O maior comprimento do pedúnculo em comparação com a folha também não é uma característica consistente para a separação dessas espécies, uma vez que há grande plasticidade foliar dentro desses táxons. De acordo com a análise dos materiais, as características importantes para a distinção dessas três espécies estão resumidas na tabela III a seguir:

Tabela III: Características diagnósticas entre Begonia apparicioi, Begonia riedelii e Begonia valdensium.

\begin{tabular}{|c|c|c|c|}
\cline { 2 - 4 } \multicolumn{1}{c|}{} & B. apparicioi & B. riedelii & B. valdensium \\
\hline Folhas & $\begin{array}{c}\text { 4(-5)lobadas, } \\
\text { margem serrilhada }\end{array}$ & $\begin{array}{c}4-5(-6) \text { lobadas, margem } \\
\text { irregularmente } \\
\text { ondulada a denteada }\end{array}$ & $\begin{array}{c}\text { inteiras a levemente lobadas, } \\
\text { margem } \\
\text { irregularmente crenulada }\end{array}$ \\
\hline Pecíolos & tomentosos & $\begin{array}{c}\text { glabros, com colar de tricomas } \\
\text { curtíssimos no ápice }\end{array}$ & $\begin{array}{c}\text { glabros, com um colar } \\
\text { de tricomas no ápice }\end{array}$ \\
\hline
\end{tabular}


MATERIAL EXAMINADO: BRASIL. MINAS GERAIS. Delfinópolis, Trilha para a cachoeira do Alpinista, 16.V.2003, Pacheco, R.A. 568, et al. (HUFU, ESA); Cachoeira do Alpinista, Paraíso Selvagem, 6.VI.2002, Volpi, R.L. 146, et al. (HUFU, ESA). Itabirito, Serra de Itabirito, 13.XI.1987, Brandão, M. 12911 (PAMG). Itamonte, Estrada para Itamonte. Beira da estrada, 22.III.2008, Delfini, C. 42, \& Paula-Souza, J. (ESA). Ouro Preto, Camarinhas, 1.VI.1980, Ferreira 8842, \& Cunha (PAMG). Passa Quatro, Estrada para a Toca do Lobo, Floresta Monatana, 21.VII.2005, Meireles. L.D. 1890, et al. (UEC); Serra Fina, Campo do Muro, Casa de Pedra, Floresta Montana, 22.III.2996, Meireles. L.D. 2199, \& Nunes, J.A. (UEC); Serra Fina, Campo do Muro, Casa de Pedra, Floresta Montana., 22.III.2006, Meireles. L.D. 2200, \& Nunes, J.A. (UEC). Santa Rita de Ibitipoca, Na mata de galeria, 19.IV.1987, Krieger, L. 21420 (SP). Santa Rita do Sapucaí, 25.V.1994, Brandão, M. 24159 (PAMG); 20.VIII.1994, Brandão, M. 24369 (PAMG); Reserva, 15.III.1996, Brandão, M. 28937 (PAMG). São Francisco dos Campos, Cultivada no Jardim Botânico de São Paulo, 28.I.1952, Handro, O. 290 (SP). São Roque de Minas, Parque Nacional da Serra da Canastra. Parte de baixo da Casca d'Anta, trilha para a cachoeira, 7.VII.1999, Farinaccio, M.A. O, et al. (SPF); Parque Nacional da Serra da Canastra, junto ao Rio São Francisco, cachoeira Casca d'Anta., 15.VII.1997, Lombardi, J.A. 1946 (SP); Estrada para o Retiro das Pedras, 14.V.1995, Romero, R. 2278, et al. (HUFU); Estrada para o Retiro das Pedras, 14.V.1995, Romero, R. 2278, et al. (ESA); Base do morro próximo a sede administrativa, 27.V.1995, Romero, R. 3534, et al. (HUFU, ESA); Serraria da Serra, Mata da Fazenda Córrego Alegre, 22.IV.1939, Kuhlmann, M. O, \& Gehrt, A. (RB 57284).

MATERIAL ADICIONAL EXAMINADO: BRASIL. EsPírITO SANTO. Itaguassu. Santa Maria, 1000m, 23.V.1946, Brade, A.C. 18387 et al. (RB). 

1861.

4.4.6. Begonia convolvulacea (Klotzsch) A. DC. in Martius, FI. bras. 4(1): 367 ,

Begonia geniculata Vell., Fl. flum. Icon. 10, pl. 51, "1827", 1831, non Jack, 1822.

Begonia rugosa hort. Schoenbrun ex Klotzsch, Monatsber. Konigl. Preuss. Akad. Wiss. Berlin, :126, 1854, pro syn. 1854.

Wageneria rugosa Klotzsch, Monatsber. Konigl. Preuss. Akad. Wiss. Berlin, :126,

Begonia scandens hort. Schoenbrun ex Klotzsch, Abh. Königl. Akad. Wiss. Berlin, 1854, :236, 1855.

Wageneria convolvulacea Klotzsch, Monatsber. Konigl. Preuss. Akad. Wiss. Berlin, :125, 1854, nomen nudum.

Wageneria schottiana Klotzsch, Abh. Königl. Akad. Wiss. Berlin, :125, 1854, nomen nudum.

Begonia repens Schott ex A. DC., Prodr. 15(1): 365, 1864, non Lamarck, 1785, pro syn.

Begonia unialata C. DC., in Huber, Bull. Herb. Boissier, II, 1:316, 1901.

(PRANCHA: fig.14: G-L, pág.40; MAPA: fig.13, pág.39)

ERVAS trepadeiras, glabras, atingindo até $2 \mathrm{~m}$ do solo. CAULES 0,4-0,9cm diâm., eretos a escandentes, estriados, simples, verdes, glabros; entrenós (0,5-)1,5-9,5cm comp. ESTÍPULAS 1,5-2cm comp., 0,5-0,8cm larg., triangulares, ápice mucronulado, base truncada, margem inteira, membranáceas, tardiamente caducas, apressas, glabras. FOLHAS com pecíolos 2,7-8,5(-11,5)cm comp., estriados, glabros; lâminas 4,5-11,5cm comp., 7,5-16cm larg., inteiras, basifixas, papiráceas, reniformes, 4-6dentados, assimétricas, ápices acuminados, base subcordada a cordada, margem dentado-serreada, glabras em ambas as faces, verdes em ambas as faces, venação actinódroma, 4-6 nervuras na base. CIMEIRAS 50-200 flores, 5-7 nós; pedúnculos 7,5-12cm comp., glabros; brácteas 1 par, 0,3-0,7cm comp., 0,2-0,3cm larg., lanceoladas, ápice mucronulado, base truncada, margem inteira, caducas, glabras. FLORES ESTAMINADAS tépalas 4, as externas ca. $5 \mathrm{~mm}$ comp., 3-4mm larg., obovais, ápice arredondado a obtuso, base truncada, margem inteira, glabras, as internas ca. $5 \mathrm{~mm}$ comp., 3-5mm larg., largamente obovais, ápice arredondado a obtuso, base aguda, margem inteira, glabras, alvas a esverdeadas; pedicelos 0,5-1,1cm comp., glabros; bractéolas 1-2 pares, 0,1-0,2 cm comp., ca. 1mm larg., lanceoladas, ápice mucronulado, base truncada, margem inteira, persistentes, glabras; estames 20-30,0,4-0,5cm comp., filetes livres; anteras aprox. 2,5mm comp., rimosas, oblongas. FLORES PISTILADAS tépalas 5, uma delas ligeiramente desigual no tamanho, aprox. $5 \mathrm{~mm}$ comp., 0,3-0,4cm larg., obovais, ápice arredondado a obtuso, base truncada, margem inteira, glabras, alvas a esverdeadas; pedicelos 1-1,5cm comp., glabros; bractéolas 1-2 pares, ca. $3 \mathrm{~mm}$ comp., ca. $1 \mathrm{~mm}$ larg., lanceoladas, ápice mucronulado, base truncada, margem inteira, inseridas no ápice do pedicelo, persistentes, glabras; estiletes $0,4-0,5 \mathrm{~cm}$ comp.; estigmas 0,3$0,4 \mathrm{~cm}$ comp., ramos cilíndricos e pouco espiralados, hipanto glabro. CÁPSULAS 0,5-1cm comp., 1-1,5cm larg., estiletes persistentes, tépalas e bractéolas caducas, região locular 
0,3-0,7cm diâm., placentas inteiras; alas desenvolvidas, diferentes entre si, sendo a maior levemente ascendente; ala maior 0,5-1cm larg., ápice arredondado; alas menores $0,1-0,3 \mathrm{~cm}$ larg. SEMENTES elípticas.

DISTRIBUIÇÃO E HÁBITATS: Begonia convolvulacea é encontrada no Vale do Rio Doce, na Zona da Mata e nas regiões Central e Sul de Minas Gerais, nos domínios da Mata Atlântica, habitando locais sombrios e úmidos, matas de encostas e matas mesófilas semi-decíduas, apoiadas em árvores ou em rochas, próximas a cursos d'água e em altitudes até 1000m (Brade, 1957B; Duarte, 1961).

FLORAÇÃO E FRUTIFICAÇÃO: floresce de junho a outubro e frutifica de julho a outubro.

COMENTÁRIOS: Begonia convolvulacea é uma planta umbrófila e apresenta como características únicas entre as espécies de Begonia de Minas Gerais a lâmina subrômbica (Smith et al., 1986), geralmente reniforme, 4-6dentadas formando ápices agudos. Além disso, os caules são glabros $e$ as inflorescências multifloras. Compartilha o hábito trepador com Begonia fruticosa A. DC. e Begonia integerrima Spreng., diferenciando-se destas espécies pelas características apresentadas na tabela IV a seguir:

Tabela IV: Características morfológicas de Begonia convolvulacea, Begonia fruticosa e Begonia integerrima.

\begin{tabular}{|c|c|c|c|}
\hline & B. convolvulacea & B. fruticosa & B. integerrima \\
\hline Hábito & herbáceo trepador & subarbustivo trepador & herbáceo trepador \\
\hline Folhas & $\begin{array}{l}\text { reniformes, } \\
\text { 4-6dentadas, } \\
\text { assimétricas }\end{array}$ & $\begin{array}{c}\text { elípticas a ovais, } \\
\text { simétricas a levemente } \\
\text { assimétricas }\end{array}$ & $\begin{array}{l}\text { ovais a largamente ovais a } \\
\text { cordiformes, simétricas a } \\
\text { levemente assimétricas }\end{array}$ \\
\hline Margem das folhas & dentado-serreada & serreada & levemente ondulada \\
\hline Venação das folhas & actinódroma & peninérvea & actinódroma \\
\hline Anteras & rimosas & rimosas, introrsas & Poricidas terminais \\
\hline Cápsulas & $\begin{array}{l}\text { alas desenvolvidas, } \\
\text { diferentes entre si, } \\
\text { sendo a ala maior } \\
\text { levemente ascendente }\end{array}$ & $\begin{array}{l}\text { alas pouco desenvolvidas } \\
\text { ou rudimentares, } \\
\text { semelhantes entre si }\end{array}$ & $\begin{array}{c}\text { alas desenvolvidas, } \\
\text { diferentes entre si, sendo a } \\
\text { ala maior levemente } \\
\text { ascendente }\end{array}$ \\
\hline Sementes & elípticas & estreitamente elípticas & fusiformes \\
\hline
\end{tabular}

MATERIAL EXAMINADO: BRASIL. MINAS GeraIs. Alpinópolis, 1997, Bufo, L.V.B. 181, et al. (ESA). Alto Caparaó, Parque Nacional do Caparaó. Vale Verde, 28.IX.1977, Krieger, L. 15121, (UFJF); Vale Verde., 3.IX.1970, Souza, A.B. 103, \& Márcia (RB); Vale Verde, 3.IX.1970, Souza, A.B. 105, \& Márcia (RB); Parque Nacional do Caparaó. Estrada entre o alojamento e Vale Verde, 1.IX.1996, Souza, V.C. 12109, et al. (ESA). Araponga, Parque Estadual da Serra do Brigadeiro. Trilha do Mucuri. 1300-1325 m.s.m., 23.III.2008, Delfini, C. 37, \& Paula-Souza, J. (ESA); Fazenda Neblina. Parque Estadual, 22.IX.2000, Leoni, L.S. 4496, (SP); Serra da Gama, a mais ou menos $1 \mathrm{~km}$ antes da Fazenda da Neblina, estrada para Bom Jesus da Madeira., 8.X.1986, Vieira, M.F. 453, Carvalho-Okano, R.M. \& Soares, M.F. (VIC). Barão de Cocais, 2.VI.1992, Brandão, M. 20799, (PAMG). Carangola, Fazenda Santa Rita. Floresta Pluvial Tropical - Mata de encosta, ao lado de manancial hídrico, 15.X.1991, Leoni, L.S. 1669, (SP). Caratinga, EBC, 27.VII.1984, Lopes, 
M.A. 326, \& Andrade, P.M. (BHCB). Coronel Pacheco, Fazenda da companhia, mata da Prata, 26.IX.1944, Heringer, E.P. 1605, (RB); Estação Experimental., 26.IX.1944, Heringer, E.P. 1606, (RB). Lajinha, Parque Florestal Municipal de Lajinha, 7.X.1986, Boechat, S. 7, (UEC). Marliéria, Parque Estadual do Rio Doce, trilha do Vinhático, 19.IX.1998, Lombardi, J.A. 2420, (BHCB); Trilha do Vinhático, 19.IX.1998, Lombardi, J.A. 2420, (SP); Reserva Florestal do Rio Doce. Mata da lagoa do Anibal, 29.VIII.1973, Sucre, D. 10117, et al. (RB); Parque Estadual do Rio Doce, trilha do Vinhático, 16.VIII.2000, Temponi, L.G. 144 et al. (VIC). Rio Doce, Córrego do Souza, distrito de Santana do Deserto, mata mesófila semi-descídua, Fazenda Paraíso, 16.X.1997, Cordeiro, I. 1657 (ESA). Sem município, Fazenda de Bocaiúva. Rio Pomba, 6.IX.1947, Heringer, E.P. 2541-54 (RB); Mexia, Y. 4980 (VIC). 


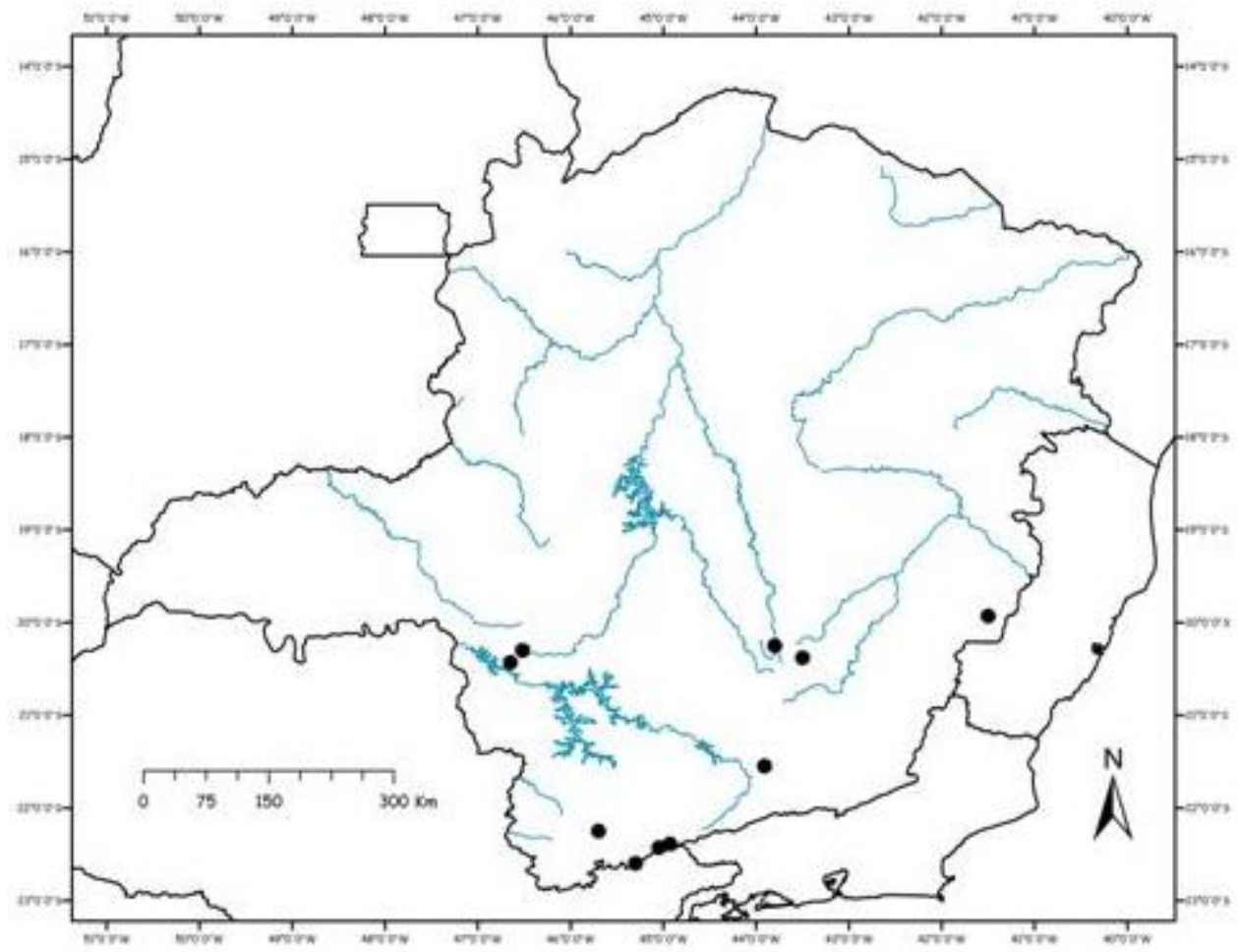

Figura 12: Mapa de distribuição geográfica de B. opporicioi

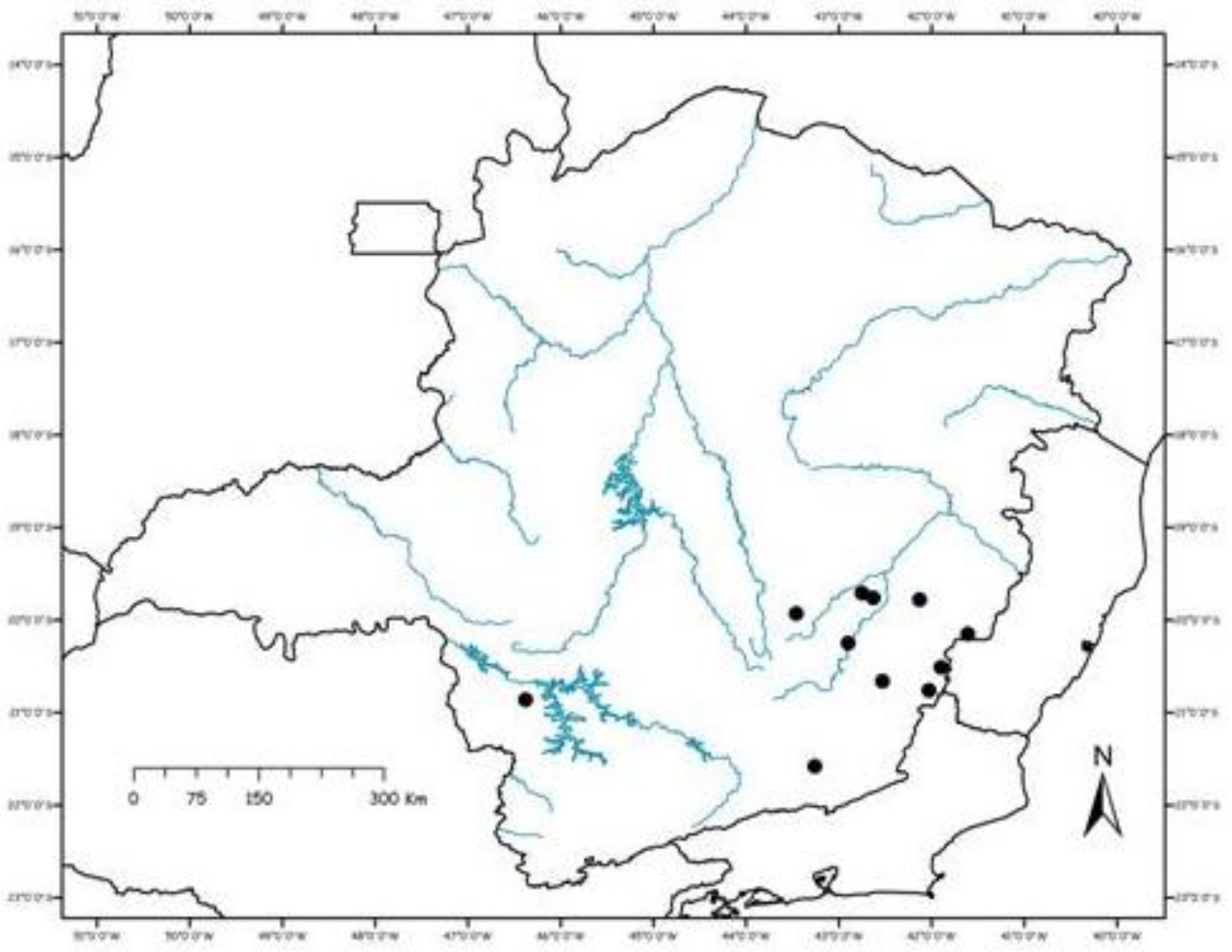

Figura 13: Mapa de distribuição geográfica de B. convokukceo 

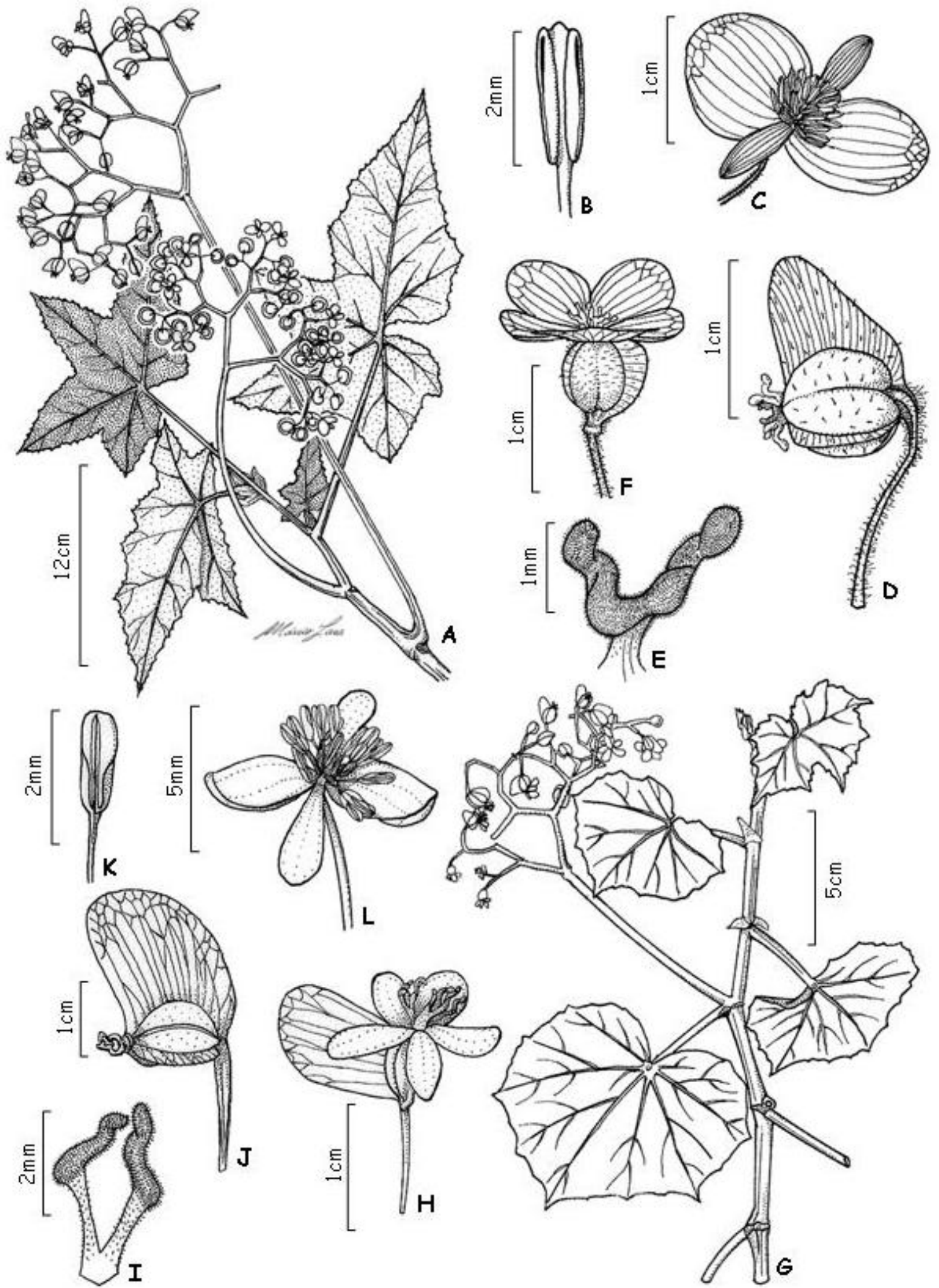

Figuro 14: A-F: B. apparicioj: A- hábito; B- estame; C- flor estaminada; D- cápsula; Eestigma; F- flor pistilada. G-L: $\boldsymbol{B}$. convolvulacea: $\mathbf{G}$ - hábito; H- flor pistilada; I- estigma; J-cápsula; K- estame; L- flor estaminada. [A-C: J.A. Lombardi, 1946 (BHCB); D- J.A. Lombardi, 1946 (BHCB); E- R.C. Forzza, 310 et ol (RB); F: M. Kuhlmann, s.n. \& A. Gehrt (ESA 103 355). G: C. Delfini, 37 \& J. Paula-Souza (ESA); H-I: L.G. Temponi, 144 et al. (VIC); J: I. Cordeiro, 1657 (ESA); K-L: L.S. Leoni, 1669 (SP)]. 
4.4.7. Begonia cucullata Willd., Sp. pl. 4: 414, 1805.

Begonia dispar Reichenbach, Mitth. Landw., ;54, 1829.

Begonia sellovii hort. ex W.J. Hooker, Bot. Mag., 56:pl. 2920, 1829, pro syn.

Begonia setaria hort. anglicis ex Graham, Edinburgh New Philos. J., :180, 1829.

Begonia hookeri Sweet, Hort. Brit., ed. 2, :437, 1830.

Begonia sellowii Klotzsch, Abh. Königl. Akad. Wiss. Berlin, 1854, :138, 1855.

Begonia cucullifolia Hasskarl, Hort. Bogor. Descr., :311, 1858.

Begonia sellowii hort. anglicis ex A. DC. in Martius, FI. bras., 4(1):342, 1861.

Begonia paludicola C. de Candolle., Bull. Soc. Bot. Genève, II, 6:125, pl. 7, 1914, "palludicold".

Begonia cucullata Willd. var. hookeri (A. DC.) L.B. Smith \& B.G. Schubert, Darwiniana, 5:104, 1941.

(PRANCHA: fig.17: A-G, pág.48; MAPA: fig.15, pág.47; FotOs: fig.18: A-C, pág.49)

ERVAS glabras, 0,3-1m alt. CAULES (0,3-)0,5-0,9cm diâm., eretos, suculentos, cilíndricos ou estriados, simples ou pouco ramificados, verdes a avermelhados, glabros; entrenós (3,5-)4,5-9,5(10,5)cm comp. ESTÍPULAS 1,2-2,5(-3)cm comp., 0,5-1,5cm larg., oblongas a ovais, ápice arredondado, base truncada, margem dentada, ciliada a fimbriada, membranáceas, persistentes, apressas, glabras. FOLHAS com pecíolos $(0,5-$ )1,5-3,5cm comp., cilíndricos, estriados, glabros; lâminas 5-9,5cm comp., 3,3-7,5cm larg., inteiras, basifixas, membranáceas, cuculadas, assimétricas, ápice obtuso a arredondado, base subaguda, margem crenada a serreada, ciliada, glabras, verdes em ambas as faces, venação actinódroma, 5-8 nervuras. CIMEIRAS 5-15 flores, 2-3(-4) nós; pedúnculos 4,55,5cm comp., glabros; brácteas 1 par, 0,5-0,6cm comp., 0,2-0,3cm larg., ovais a elípticas, ápice agudo, base truncada, margem fimbriada, tardiamente caducas, glabras. FLORES ESTAMINADAS tépalas 4, as externas 0,5-1cm comp., 0,6-1,1cm larg., orbiculadas, ápice arredondado, base arredondada a subcordada, margem inteira, glabras, as internas 0,5-0,7cm comp., 0,2-0,3cm larg., elípticas, ápice arredondado, base aguda, margem inteira, glabras, alvas a róseas; pedicelos 0,5-1,5cm comp., glabros; bractéolas 1-2 pares, ca. $3 \mathrm{~mm}$ comp., ca. $1 \mathrm{~mm}$ larg., espatuladas, ápice arredondado, base truncada, margem fimbriada, persistentes, glabras; estames 40-70, 0,5-0,6cm comp., filetes livres; anteras ca. $3 \mathrm{~mm}$ comp., rimosas, oblongas. FLORES PISTILADAS tépalas 5, subiguais, sendo uma delas ligeiramente diferente no tamanho e forma, 0,7-1,3cm comp., 0,4-0,8cm larg., ovais a largamente ovais, ápice arredondado, base truncada, margem inteira, glabras, alvas a róseas; pedicelos 1-2,5(-2,7)cm comp., glabros; bractéolas 1-2 pares, ca. $5 \mathrm{~mm}$ comp., 2-3mm larg., ovais a obovais, ápice arredondado, base truncada, margem fimbriada, uma inserida abaixo do hipanto e duas inseridas no ápice do pedicelo, persistentes, glabras; estiletes 4-5mm comp.; estigmas cerca $3 \mathrm{~mm}$ comp., ramos cilíndricos e espiralados, hipanto glabro. CÁPSULAS 1,5-2cm comp., 1,5-2,3cm larg., estiletes e bractéolas persistentes, tépalas caducas, região locular 0,5-1,4cm diâm., placentas partidas; alas diferentes entre si, sendo a ala maior ascendente; ala maior 0,7- 
$1,5 \mathrm{~cm}$ larg., ápice agudo; alas menores 0,3-0,5cm larg. SEMENTES elípticas a fusiformes com ápice acuminado.

DISTRIBUIÇÃO E HÁBITATS: Begonia cucullata ocorre no Vale do Jequitinhonha, no Vale do Rio Doce, Vale do Paranaíba, nas regiões Central e Sul de Minas Gerais, na região metropolitana de Belo Horizonte, nas Vertentes e em Alto São Francisco, em áreas dominadas por campos, campos rupestres, Cerrado e pela Mata Atlântica, habitando locais alagadas ou temporariamente alagados, margens de rios e córregos, matas de galerias, locais úmidos e sombreados, áreas perturbadas, veredas, campos limpos, escarpas rochosas, entre fendas de rochas ou sob pedras, bordas de matas e em solos argilosos.

FLORAÇÃO E FRUTIFICAÇÃO: floresce e frutifica praticamente o ano todo.

COMENTÁRIOS: Begonia cucullata é uma espécie de fácil reconhecimento mesmo em estado vegetativo, tanto no campo quanto no material herborizado. Possui características únicas dentre as demais espécies do gênero Begonia de Minas Gerais e pode ser prontamente identificada pela forma cuculada das folhas e pelas estípulas oblongas a ovais. Além disso, Begonia cucullata possui insigne potencial ornamental evidenciado pelas cimeiras com flores vistosas e, portanto, habitualmente esta espécie é cultivada em jardins.

Baseado na forma das folhas, estípulas e sementes, Golding (1982); Smith et al. (1986) e Golding \& Wasshausen (2002), reconhecem três variedades para Begonia cucullata, de acordo com a tabela $V$ abaixo:

Tabela V: Características diagnósticas das variedades de Begonia cucullata. $B$. cucullata var. cucullata, B. cucullata var. arenosicola (C. DC.) L.B. Smith \& B.G Schubert e B. cucullata var. spatulata (Loddiges) J. Golding, de acordo com Golding (1982).

\begin{tabular}{|c|c|c|c|}
\cline { 2 - 5 } \multicolumn{1}{c|}{} & $\begin{array}{c}\text { B. cucullata var. } \\
\text { cucullata }\end{array}$ & $\begin{array}{c}\text { B. cucullata var. } \\
\text { arenosicula }\end{array}$ & $\begin{array}{c}\text { B. cucullata var. } \\
\text { spatulata }\end{array}$ \\
\hline Folhas & $\begin{array}{c}\text { cordadas a } \\
\text { oblongas com margem } \\
\text { denticulada }\end{array}$ & $\begin{array}{c}\text { largamente } \\
\text { elípticas, margem } \\
\text { inteira }\end{array}$ & $\begin{array}{c}\text { largamente ovais, } \\
\text { margem } \\
\text { não mencionada }\end{array}$ \\
\hline Ápicípulas & $\begin{array}{c}\text { oblongas } \\
\text { com } \\
\text { margem dentada }\end{array}$ & $\begin{array}{c}\text { elípticas } \\
\text { com } \\
\text { margem inteira }\end{array}$ & $\begin{array}{c}\text { Oblongas } \\
\text { com } \\
\text { margem ciliada }\end{array}$ \\
\hline gementes & $\begin{array}{c}\text { geralmente prolongado, } \\
\text { agudo a } \\
\text { acuminado }\end{array}$ & obtuso & obtuso \\
\hline
\end{tabular}

Morfologicamente Begonia semperflorens Link \& Otto é bastante similar à Begonia cucullata, diferenciando-se desta espécie pelas folhas planas, pelas estípulas pequenas e escariosas e pelas sementes obtusas (Jacques, 2002). Com relação à distribuição geográfica, Jacques (2002) observou que, embora ocorra uma pequena sobreposição, Begonia cucullata apresenta área de distribuição mais ampla, enquanto Begonia semperflorens possui área de distribuição geográfica mais restrita. Além disso, 
esta autora concluiu que as variedades anteriormente propostas representam híbridos entre essas duas espécies. Algumas características morfológicas importantes na separação de Begonia cucullata e Begonia semperflorens estão apresentadas na tabela VI a seguir:

Tabela VI: Características morfológicas entre Begonia cucullata e Begonia semperflorens, segundo Jacques (2002).

\begin{tabular}{|c|c|c|}
\hline & B. cucullata & B. semperflorens \\
\hline Folhas & cuculadas, arredondadas & $\begin{array}{l}\text { planas, assimétricas, } \\
\text { transversalmente } \\
\text { oblongas }\end{array}$ \\
\hline Estípulas & oblongas & triangulares \\
\hline Estípulas X Pecíolos (comp.) & maiores & menores \\
\hline Estípulas do mesmo nó & diferentes & iguais \\
\hline Sementes & elípticas, ápice agudo & oblongas, ápice arredondado \\
\hline Distribuição & $\begin{array}{c}M G, R J, S P, M S, M T, P R, S C, R S \\
\text { até a } \\
\text { Argentina }\end{array}$ & $\begin{array}{l}\text { SC, PR, RS } \\
\text { até a } \\
\text { Argentina }\end{array}$ \\
\hline
\end{tabular}

MATERIAL EXAMINADO: BRASIL. Minas GeraIs. Araponga, Parque Estadual da Serra do Brigadeiro. Estrada para a entrada do Parque, 23.III.2008, Delfini, C. 47, \& Paula-Souza, J. (ESA); Serra da Araponga - Fazenda Neblina. Cresce na trilha "Ranunculaceae" em área perturbada, 26.V.1994, Leoni, L.S. 2567, (SP). Araxá, Campo Limpo, 1.IV.1993, Brandão, M. 22057, (PAMG). Barão de Cocais, 14.VIII.1991, Brandão, M. 19426, (PAMG); 28.VI.1992, Verissimo, P. 1053, (PAMG). Belo Horizonte, Jardim Botânico, 26.VIII.1932, Barreto, M. 1843, (BHCB); Horto da UFMG., 26.V.1980, Cunha, L.H.S. 352, (PAMG); Serra do Curral, 25.4.1991, Pio 190, (PAMG). Borda da Mata, 4.XII.1991, Veríssimo, P. 683, (PAMG). Caldas, 3.XII.1991, Veríssimo, P. 634, (PAMG). Camanducaia, Monte Verde. Trilha do Bispo, 18.V.2002, Kinoshita, L.S. 86, et al. (UEC); Monte Verde (Área alagada), 8.IV.2002, Meireles. L.D. 918, et al. (UEC); Monte Verde - Serra da Mantiqueira, 22.IV.2002, Meireles. L.D. 1056, et al. (UEC). Campo Florido, Estrada para Campo Florido - Fundo esquerdo da Vereda 3, 12.II.1999, Barbosa, A.A. 1320, \& Amaral, A.F. (HUFU); Carrancas, Propriedade do Sr. José Pinto, 2.XII.1998, Simões, A.0. 599, et al. (UEC). Conceição do Mato Dentro, Capitão Felizardo, III.2002, Freitas, V.O. s.n., et al. (HXBH 14426); Capitão Felizardo, VII.2003, Freitas, V.O. s.n., et al. (HXBH 14407). Conquista, 17.XII.1988, Pedralli s.n., \& Meyer (HXBH 8056). Coromandel, Ribeirão da Confusão UHE/ Bocaina, Brandão, M. 14523 (PAMG). Coronel Pacheco, Estação Experimental, 11.XI.1944, Heringer, E.P. 1637, (RB); Fazenda Boa Ventura, 18.XI.1944, Heringer, E.P. 1647, (RB); Fazenda da Barra, 15.I.1945, Heringer, E.P. 1727 (RB). Diamantina, 24.V.1955, Pereira, E. 1504 (RB). Governador Valadares, Fazenda EPAMIG - Área 4., 20.IV.1987, Cunha, L.H.S. 1001 (PAMG). Itabirito, Pico do Itabirito, 25.II.1995, Teixeira, W.A. s.n. (SP 27268, BHCB 26506). Limeira, Estrada entre Limeira e Esvália, 28.XI.1985, Xavier, A. s.n. (VIC 9459). Marliéria, Parque Estadual do Rio Doce. Floresta Estacinal Semidecidual. Solo argiloso vermelho, 18.V.1982, Bautista, H.P. 559, (RB). Monte Verde, Brejo no caminho para o Parque das Nações, 27.IV.2001, Marcondes-Ferreira, W. 1738, \& Tsuji, R. (UEC, ESA). Nova Ponte, Rio Araguari, 25.III.1987, Meyer, S. T. s.n. (HXBH 3329). Ouro Preto, Estação Ecológica do Tripuí, IX.1997, Werneck s.n. (HXBH 11734). Poços de Caldas, 21.XI.1988, Motta, J.T. 1488, (MBM); Campo do saco. Em depressões do campo, 7.II.1983, Semir, J. 1944, \& Stubblebine, W.H. (UEC); Campo do saco, 19.XI.1980, Stubblebine, W.H. 510, (UEC). Prudente de Morais, Lago 4, 15.II.2000, Macedo, 
J.F. 3942, (PAMG). Sacramento, Gruta dos Palhares, 23.II.1989, Brandão, M. 14983, (PAMG). Santa Rita do Sapucaí, Balaio, 11.I.1997, Brandão, M. 27870, (PAMG). Santana do Riacho, Estátua do Juca, 22.XI.2000, Kinoshita, L.S. O, \& Matsumoto, K. (UEC); Santana do Riacho, Rodovia Belo Horizonte - Conceição do Mato Dentro. Margem do rio Parauninha, próximo a Usina Pacífico Mascarenhas, 11.III.1990, Vitta, F.A. s.n. \& Souza, V.C. (SPF 67794). São José do Barreiro, Parque Nacional da Serra da Canastra. Acesso pela portaria Casca d'Anta. Cachoeira Casca d'Anta, 2.X.2007, Delfini, C. 29, \& Romão, G.O. (ESA). São Roque de Minas, Parque Nacional da Serra da Canastra. Acesso pela Portaria São Roque de Minas. Parte alta da Cachoeira Casca d'Anta, 2.X.2007, Delfini, C. 22, \& Romão, G.O. (ESA); Parque Nacional da Serra da Canastra - Trilha na escarpa ca Choeira Casca d'Anta, pela portaria Casca d'Anta, 8.XI.2002, Lima, L.R. 201, et al. (SPF); Base do morro próximo a sede administrativa, 19.XI.1995, Nakajima, J.N. 1459, et al. (ESA). Sete Lagoas, CNPMS - Lago 5, margem brejeira, 29.IX.1998, Macedo, J.F. 2988, (PAMG). Timóteo, Parque Estadual do Rio Doce, 6.VIII.2004, França, G.S. 566, et al. (BHCB). Tiradentes, Serra São José, 1997, Brina, A.E. s.n. (BHCB 39549). Uberlândia, Estação Ecológica do PANGA - Vereda 4 (esquerdo, meio fundo), 26.III.1999, Araújo, G.M. s.n. \& Barbosa, R.A. (HUFU 1959); Vereda 4 situada na parte oeste da Estação Ecológica do PANGA - fundo da vereda, lado direito, 28.IV.2000, Barbosa, A.A. 3554, (HUFU); Fazenda Experimental do Glória (UFU), 16.III.1994, Nakajima, J.N. 242, et al. (ESA); Fazenda Pinusplan, a 6km da BR 050, na altura do km 25, 23.II.2002, Oliveira, G.C. 152, (HUFU); Reserva Vegetal do Clube Caça e Pesca Itororó de Uberlândia, a 300m da estrada vicinal RM 479, na altura do km1,3, 28.II.2002, Oliveira, G.C. 270, (ESA); Reserva Vegetal do Clube Caça e Pesca Itororó de Uberlândia, a 300m da estrada vicinal RM 479, na altura do km1,3, 23.III.2002, Oliveira, G.C. 379 (ESA); Fazenda Pinusplan, a 6km da BR 050, na altura do km 25, 24.III.2002, Oliveira, G.C. 418 (ESA); Fazenda Pinusplan, a 6km da BR 050, na altura do km 25, 16.VIII.2002, Oliveira, G.C. 1056 (ESA); Fazenda Pinusplan, a 6km da BR 050, na altura do km 25, 27.V.2003, Oliveira, G.C. 2523 (ESA); Estação Ecológica do PANGA, 20.V.1999, Ranal, M. 712 (HUFU); Estação Ecológica do PANGA. Mata de galeria, 3.VI.1999, Ranal, M. 754 (HUFU). Viçosa, Campus da UFV, viveiro da Vila Gianetti, 9.XI.992, Carvalho, A.F. 184 (VIC); UFV, Vila Gianetti, grupo entre folhas, 18.XI.1999, Carvalho, A.F. 647 (VIC); Campus da UFV, 6.XI.1994, Coelho, L.B.V. 82, (VIC); Campus da UFV, canteiro em frente ao restaurante, 29.IV.1984, Garcia, M.V.B. s.n. (VIC 8673); Campus da UFV, canteiro em frente ao restaurante, 15.V.1984, Gonçalves. L.O.O. s.n. \& Donato, P.E.R. (VIC 7835); State Agricultural School, 30.XI.1958, Irwin, H.S. 2183 (VIC); ESAV, 23.I.1935, Kuhlmann s.n. (VIC 2432); Fazenda de Aguada - small valley 1,5km, from entrance; open, marshy area, 16.X.1930, Mexia, Y. 5190 (VIC); São José do Triunfo, sítio São José do Triunfo, estrada de terra a direita da Igreja, 14.VII.1992, Vieira, M.F. 741, \& Soares, M.F. (VIC). Virgolândia, Redondezas do Rio Suaçuí Grande, 7.VII.2001, Mota, R.C. 1401, (BHCB). 
4.4.8. Begonia curtii L.B. Smith \& B.G. Schubert, J. Wash. Acad. Sci., 45:114, 1955.

Begonia velata Brade, Arq. Jard. Bot. Rio de Janeiro, 10: 33, pl. 2, 1950, Tipo: Brasil: Espírito Santo. Município de Castelo, Forno Grande, 1100-1200m sobre o nível do mar, Brade 19783, V/1949 (Holótipo: RB!, Isótipos: RB!), non L.B. Smith \& B.G. Schubert, 1941.

(PRANCHA: fig.17: H-K, pág.48; MAPA: fig.16, pág.47; FOTOS: fig.11: A-B, pág.32)

ERVAS glabras, exceto os pecíolos (lanosos), 30-40 cm alt. CAULES 0,7-1,5cm diâm., envolvido por vastas estípulas, eretos, subcarnosos, cilíndricos, lisos, simples a pouco ramificados, marrons, glabros; entrenós 0,8-1,5cm comp. ESTÍPULAS 4,5-5,5cm comp., 2,5-3,5cm larg., obovais a oblongas, ápice retuso, base truncada, margem inteira a levemente ondulada, membranáceas, persistentes, apressas, glabras. FOLHAS com pecíolos 5,5-7(-9,5)cm comp., cilíndricos, levemente estriados, lanosos, tricomas simples, longos e finos; lâminas $11-15,5 \mathrm{~cm}$ comp., 4-8cm larg., inteiras, basifixas, cartáceas, oblíquas a transversais, ovais, assimétricas, ápice acuminado, base cordada, margem inteira a levemente ondulada, glabras em ambas as faces, verdes em ambas as faces, venação actinódroma, 4-6 nervuras na base. CIMEIRAS 50-100 flores, 4-5 nós; pedúnculos 19-25cm comp., glabros; brácteas 1 par, comprimento, largura, forma, ápice, base e margem não vistos, caducas, indumento não visto. FLORES ESTAMINADAS [tépalas 4, as externas ca. $10 \mathrm{~mm}$ comp., aprox. $9 \mathrm{~mm}$ larg., suborbiculares], ápice, base, margem $e$ indumento não vistos, [as internas ca. $7,5 \mathrm{~cm}$ comp., aprox. $4 \mathrm{~mm}$ larg., ovais], ápice, base, margem $e$ indumento não vistos, alvas a róseas; pedicelos não vistos; bractéolas 1-3 pares, comp., larg., forma, ápice, base e margem não vistos, caducas, indumento não visto; [estames ca. 22, aprox. $3 \mathrm{~mm}$ comp., filetes livres; anteras ca. $1 \mathrm{~mm}$ comp., rimosas, ovais a oblongas]. FLORES PISTILADAS tépalas 5, semelhantes entre si, ca. $6 \mathrm{~mm}$ comp., aprox., $2 \mathrm{~mm}$ larg., elípticas, ápice obtuso, base truncada, margem levemente ondulada, glabras, alvas a róseas; pedicelos 0,8-1 cm comp., glabros; bractéolas 1-3 pares, comp., larg., forma, ápice, base e margem não vistos, inseridas diretamente no pedicelo, caducas, indumento não visto; estiletes ca. $2 \mathrm{~mm}$ comp., ramos cilíndricos e espiralados, hipanto glabro. CÁPSULAS 0,5-1cm comp., ca. $1 \mathrm{~cm}$ larg., estiletes persistentes, tépalas e bractéolas caducos, região locular 0,3-0,5cm comp., placentas inteiras; alas desenvolvidas, uma delas um pouco maior que as demais; ala maior ca. $4 \mathrm{~mm}$ larg., ápice obtuso; ala menor 2-3mm larg. SEMENTES oblongas.

DISTRIBUIÇÃO E HÁBITATS: Begonia curtii ocorre na Zona da Mata mineira, nos domínios da Mata Atlântica, habitando escarpas rochosas.

FLORAÇÃO E FRUTIFICAÇÃo: floresce no mês de dezembro e frutifica no mês de março.

COMENTÁRIOS: Begonia curtii é uma erva semi-heliófila que se diferencia das demais espécies do gênero Begonia de Minas Gerais, pelos caules envolvidos por estípulas grandes, persistentes e venosas, com ápice retuso e pelo revestimento dos pecíolos. 
Esta espécie possui insigne potencial ornamental, responde bem ao cultivo e, portanto, habitualmente esta é cultivada em jardins.

Begonia curtii é bastante semelhante à Begonia venosa Skan ex J.D. Hooker, principalmente por compartilharem as estípulas grandes, persistentes e venosas, entretanto, nesta última espécie, as estípulas se diferenciam pelo ápice oblongo a arredondado e por outras características morfológicas tais como o revestimento das folhas, as placentas partidas e as cápsulas com alas rudimentares.

MATERIAL EXAMINADO: BRASIL. MINAS GERAIS. Faria Lemos, Fazenda Santa Rita. Sobre escarpa rochosa, 30.VII.1999, Leoni, L.S. 4332, (SP).

MATERIAL ADICIONAL EXAMINADO: BRASIL. EsPírITO SANTO. Castelo, Forno Grande, no lajão, 1100-1200m sobre o nível do mar, 12.V.1949, Brade, A.C. 19783 (RB). Pedra Azul, Estrada para o Parque Estadual da Pedra Azul. Pousada Peterle, em cultivo, 27.III.2008, Delfini, C. 48, \& Paula-Souza, J. (ESA). 


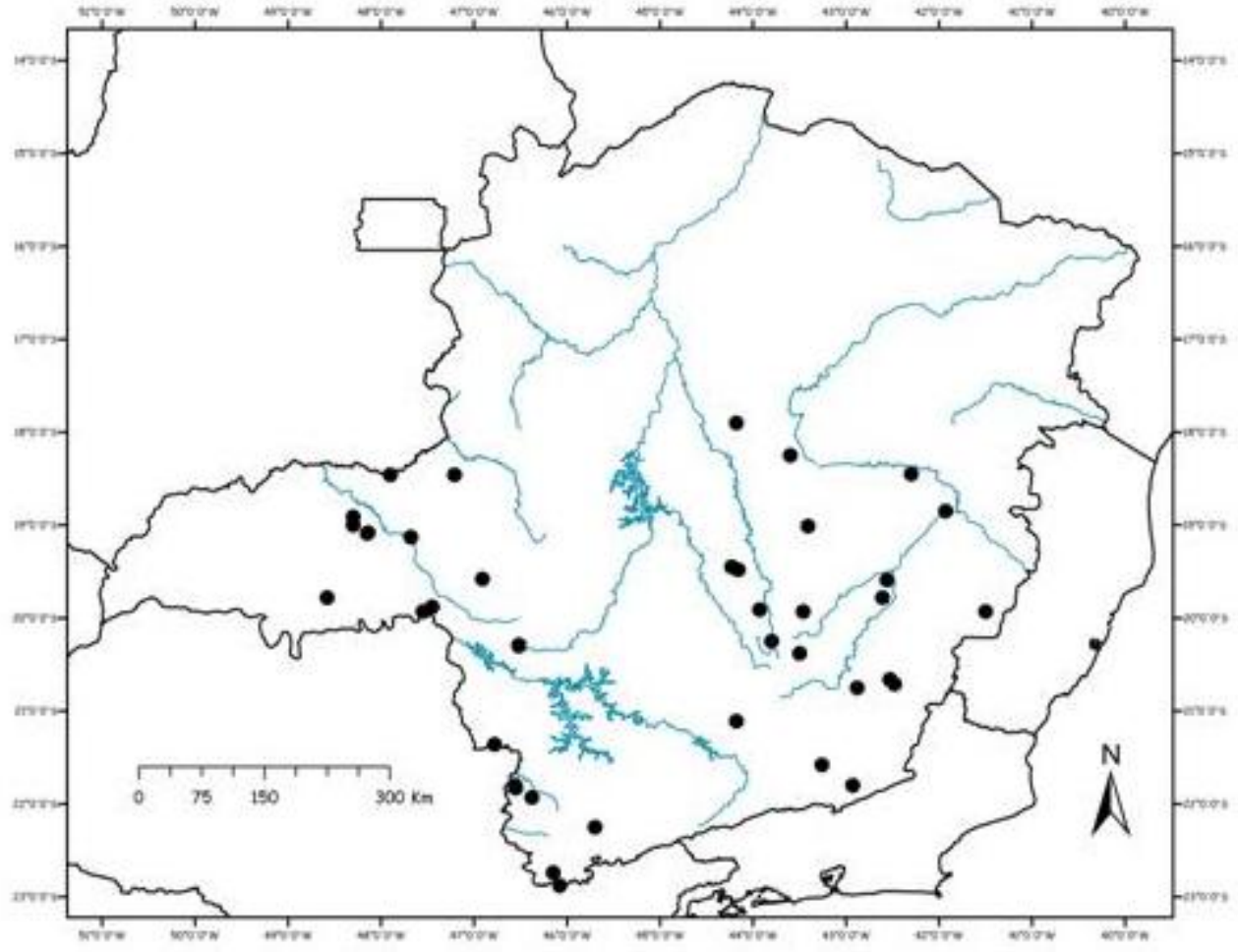

Figuro 15: Mapa de distribuição geográfica de B. cuculloto

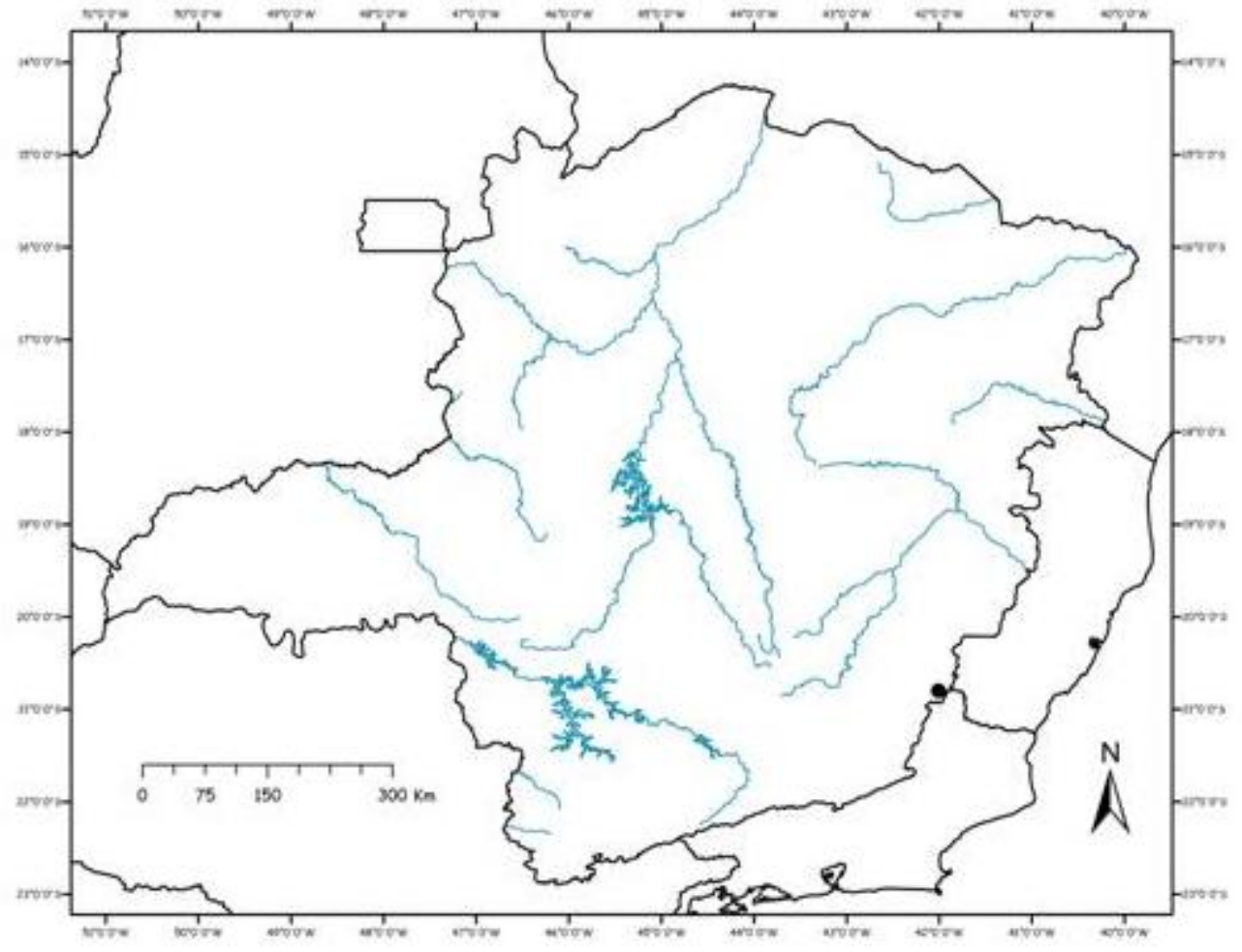

Figura 16: Mapa de distribuição geográfica de B. curtii $\bullet$ 


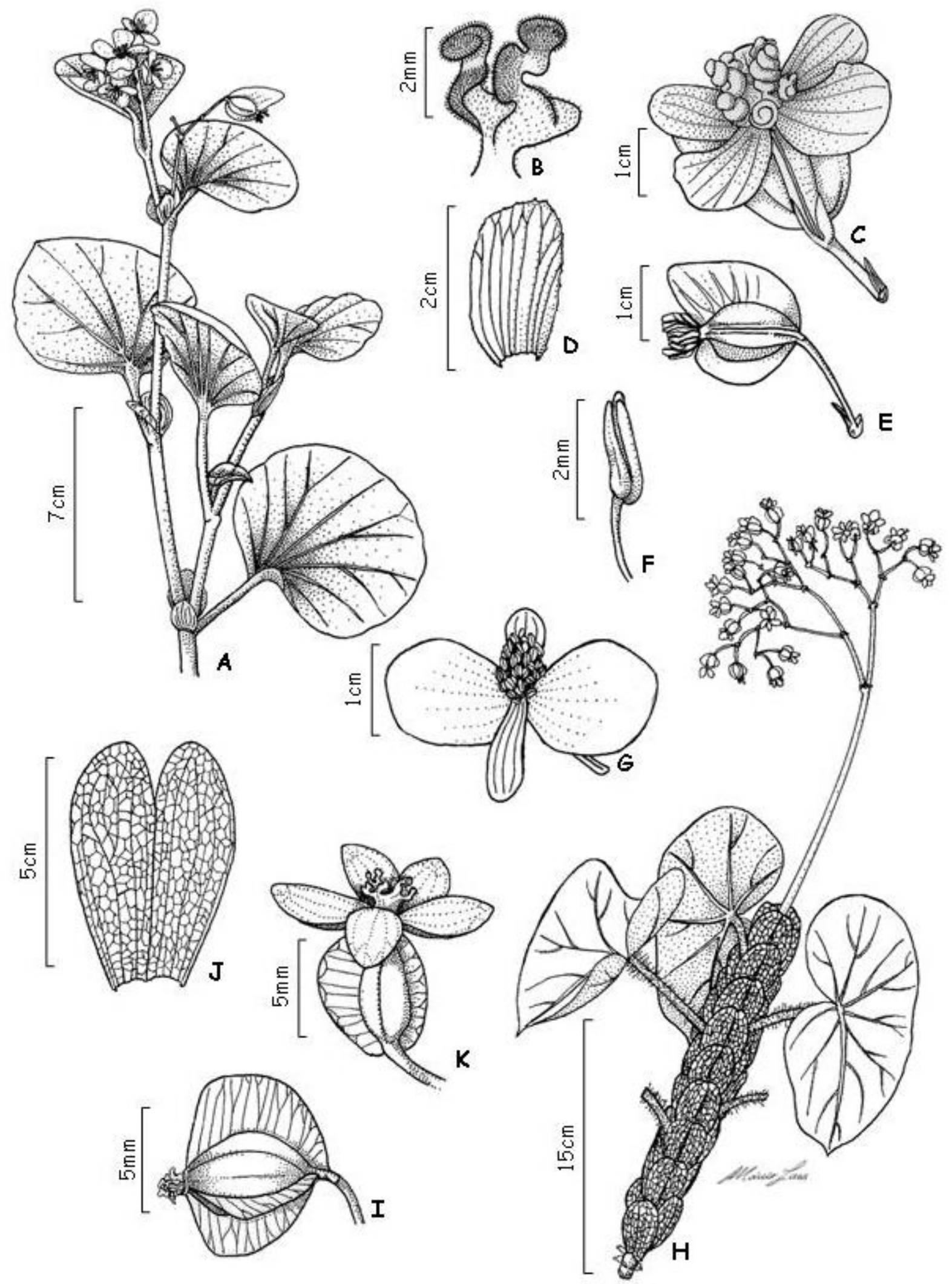

Figuro 17: A-G: B. cuculata: A- hábito; B- estigma; $C$ - flor pistilada; D- estípula; Ecápsula; F- estame; G- flor estaminada H-K: $\boldsymbol{B}$. curtij: H- hábito; I- cápsula; J- estípula; K- flor pistilada. [A-G: C. Delfini, 47 \& J. Paula-Souza (ESA). H: L.S. Leoni, 4332 (SP); I-J: C. Delfini, 48 \& J. Paula-Souza (ESA); K- L.S. Leoni, 4332 (SP)]. 

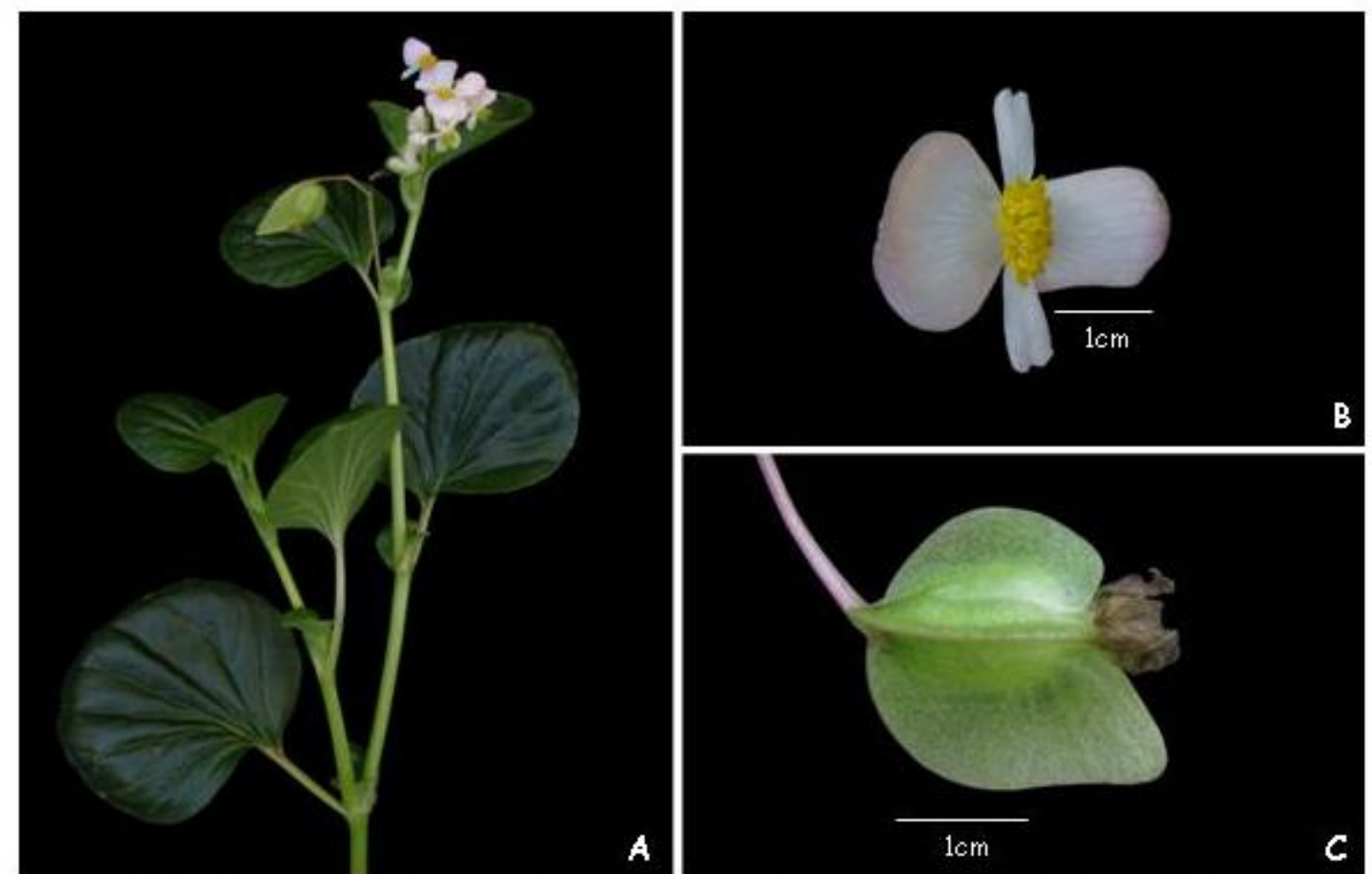

Figura 18: B. cucullota. A-ramo; B-detalhe da flor estaminada; C-detalhe da cápsula.
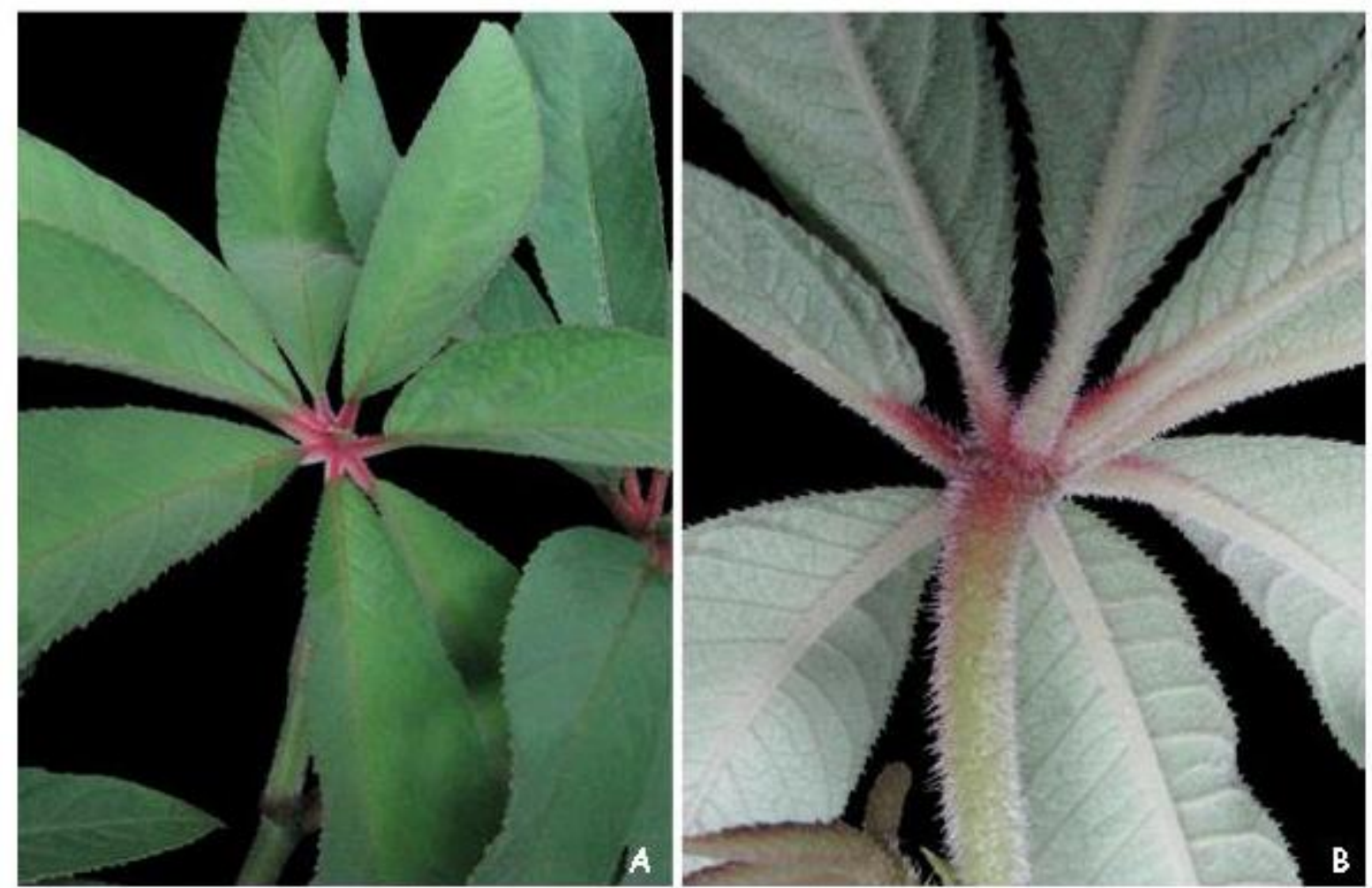

Figura 19: B. digitota. A- face adaxial da folha; B - face abaxial da folha, detalhe do indumento. 
4.4.9. Begonia digitata Raddi, Mem. Mat. Fis. Soc. Ital. Sci., Modena, 18:406, 1820.

Begonia verticillata Vell., Fl. flum., icon., pl. 45, "1827", 1831.

Scheidweileria digitata (Raddi) Klotzsch, Monatsber. Königl. Preuss. Akad. Wiss. Berlin, :123, 1854.

(PRANCHA: fig.22: A-F, pág.57; MAPA: fig.20, pág.56; Fotos: fig.19: A-B, pág.49)

ERVAS robustas, panosas, indumento formado por tricomas finos (simples, barbados $e$ dicotômicos) e por tricomas mais espessos (fimbriados), 1-2,5cm comp. CAULES 0,5$1,5 \mathrm{~cm}$ diâm., eretos, suculentos, estriados, simples verdes a avermelhados, glabrescentes; entrenós 2-6cm comp. ESTÍPULAS 1,4-1,5cm comp., ca. 0,5cm larg., triangulares, ápice mucronulado, base truncada, margem irregularmente ondulada, ciliada, papiráceas, caducas, apressas, com tricomas no dorso. FOLHAS com pecíolos 7,5-13,5(-23)cm comp., estriados, glabrescentes; lâminas palmatissectas, segmentos 17$22 \mathrm{~cm}$ comp., 4-7,5cm larg., papiráceos, elípticos, simétricos a levemente assimétricos, ápices acuminados, bases agudas, margem irregularmente serreada não atingindo o ponto de onde irradiam as nervuras, deixando uma parte das mesmas expostas, glabrescente, com o indumento distribuído mais densamente na face abaxial das folhas e sob as nervuras, verdes em ambas as faces, 9-15 segmentos peninérveos. CIMEIRAS ca. 500 flores, 6-8 nós; pedúnculos (5,5-)15-31cm comp., glabrescentes; brácteas 1 par, ca. $2 \mathrm{~mm}$ comp., aprox. $1 \mathrm{~mm}$ larg., triangulares, ápice mucronulado, base truncada, margem irregularmente ondulada, caducas, panosas. FLORES ESTAMINADAS tépalas 4 , as externas ca. $4 \mathrm{~mm}$ comp., aprox. $3 \mathrm{~mm}$ larg., largamente ovais, ápice arredondado, base arredondada, margem inteira a irregularmente ondulada, glabrescentes, as internas ca. $4 \mathrm{~mm}$ comp., 2-3mm larg., ovais, ápice arredondado, base aguda, margem inteira a irregularmente ondulada, glabras, alvas a esverdeadas; pedicelos $6-8 \mathrm{~mm}$ comp., glabrescentes; bractéolas 1-2 pares, 5-6mm comp., 1-2mm larg., triangulares, ápice mucronulado, base truncada, margem irregularmente ondulada, caducas, panosas; estames 20-25, 3-4mm comp., filetes livres; anteras ca. $1 \mathrm{~mm}$ comp., rimosas, oblongas. FLORES PISTILADAS tépalas 5, semelhantes entre si, 3-4m comp., 2-3mm larg., ovais, ápice agudo, base truncada, margem levemente ondulada, glabras, alvas a esverdeadas; pedicelos 6-7mm comp., panosas; bractéolas 1-2 pares, 5-6mm comp., ca. $1 \mathrm{~mm}$ larg., triangulares, ápice mucronulado, base truncada, margem levemente ondulada, inseridas diretamente no pedicelo, caducas, panosas; estiletes ca. $2 \mathrm{~mm}$ comp.; estigmas aprox. $1 \mathrm{~mm}$ comp., ramos cilíndricos e espiralados, hipanto panoso. CÁPSULAS 5-6mm comp., 6$8 \mathrm{~mm}$ larg., estiletes persistentes, tépalas e bractéolas caducos, região locular $3-4 \mathrm{~mm}$ diâm., placentas inteiras; alas semelhantes entre si, 1-3mm larg., ápice arredondado. SEMENTES oblongas a oblanceoladas.

DISTRIBUIÇÃO E HÁBITATS: Begonia digitata é encontrada na Zona da Mata e no Sul de Minas Gerais, nos domínios da Mata Atlântica, habitando encostas e tanto locais 
sombrios como interiores de mata quanto locais iluminados como beira de córregos e clareiras de matas.

FLORAÇÃO E FRUTIFICAÇÃO: floresce no mês de setembro e frutifica no mês de outubro.

COMENTÁRIOS: Begonia digitata é uma erva robusta caracterizada pelas folhas palmatissectas com segmentos de bases agudas não atingindo o ponto de onde irradiam as nervuras, deixando, portanto, uma parte das mesmas expostas.

Smith et al. (1986) e Golding \& Wasshausen (2002), reconhecem duas variedades para Begonia digitata. B. digitata var. digitata e B. digitata var. rufescens Irmsch., sendo esta última caracterizada pelo porte mais robusto e pelas maiores dimensões dos segmentos. Entretanto, considerando toda a variação morfológica, principalmente das folhas, encontrada nos espécimes coletados em Minas Gerais, não é possivel reconhecer táxons sub específicos, mas como foram avaliados somente espécimes de Minas Gerais e como também não foram analisados os tipos dos nomes em questão, não será possível concluir a respeito de sinonimizações das variedades, embora seja evidente que suas características diagnósticas sejam inconsistentes e provavelmente, não são suficientes para sustentá-las como variedades distintas.

Morfologicamente, Begonia digitata, Begonia incisoserrata A. DC. e Begonia luxurians Scheidw. são bastante semelhantes, diferenciando-se pelas características apresentadas na tabela VII a seguir:

Tabela VII: Características diagnósticas entre Begonia digitata, Begonia incisoserrata e Begonia luxurians.

\begin{tabular}{|c|c|c|c|}
\cline { 2 - 4 } \multicolumn{1}{c|}{} & B. digitata & B. incisoserrata & B. luxurians \\
\hline Indumento & panoso & escabroso & lanuginoso \\
\hline $\begin{array}{c}\text { Margem dos } \\
\text { segmentos }\end{array}$ & $\begin{array}{c}\text { irregularmente } \\
\text { serreada não atingindo } \\
\text { o ponto de onde } \\
\text { irradiam as nervuras }\end{array}$ & $\begin{array}{c}\text { dentado-serreada, não } \\
\text { atingindo o ponto a } \\
\text { partir de onde } \\
\text { irradiam as nervuras }\end{array}$ & $\begin{array}{c}\text { serreada a serrilhada } \\
\text { atingindo o ponto a } \\
\text { partir de onde irradiam } \\
\text { as nervuras }\end{array}$ \\
\hline Base dos segmentos & aguda & aguda & atenuada \\
\hline
\end{tabular}

MATERIAL EXAMINADO: BRASIL. Minas GeraIs. Alto Caparaó, ParNa do Caparaó. Vale Verde, 25.III.2008, Delfini, C. 36, \& Paula-Souza, J. (ESA); Parque Nacional do Caparaó. Vale Verde. Beira do córrego, 18.VIII.1999, Mazine, F.F. 163, \& Forster, W. (ESA); Pico da Bandeira perto de Caparaó, em mata e beira de mata, 6.IX.1977, Schepherd, G.J. 5767 et al. (UEC, RB); Vele Verde. Em lugar bem sombrio, 3.IX.1970, Souza, A.B. 107, \& Márcia (RB). Passa Quatro, Fazenda Sertão dos Martins. Na mata, lugar sombrio, 21.IV.1948, Araújo, S. 194, \& Alt. Barb. (RB); Rio Retiro, 3.V.1948, Brade, A.C. s.n. (RB 148865). Piau, Fazenda do Serrote, 26.II.1945, Heringer, E.P. 1935 (RB). 
4.4.10. Begonia fischeri Schrank, PI. Rar. Hort. Acad. Monac., 2: pl. 59, 1820.

Begonia patula Haworth, Succ. PI. Suppl., :100, 1819.

Begonia patula Fischer ex Hornemann, Hort. Hafin. Suppl., :108, 1819, non Haworth, 1819.

Begonia obliqua Vell., FI. flum., icon., 10:pl. 48, "1827", 1831, non Linnaeus, 1753.

Begonia brasiliensis Klotzsch, Monatsber. Königl. Preuss. Akad. Wiss. Berlin, :122, 1854, nomen nudum; Abh. Königl. Akad. Wiss. Berlin 1854, :154, 1855.

Begonia elata Klotzsch, Monstsber. Königl. Preuss. Akad. Wiss. Berlin, :122. 1854, nomen nudum; Abh. Königl. Akad. Wiss. Berlin 1854, :155, 1855.

Begonia moritziana Klotzsch, Monstsber. Königl. Preuss. Akad. Wiss. Berlin, :122, 1854

Begonia setosa Klotzsch, Monatsber. Königl. Preuss. Akad. Wiss. Berlin, :122, 1854, nomen nudum; Abh. Königl. Akad. Wiss. Berlin 1854, :151, 1855.

Begonia tovarensis Klotzsch, Monatsber. Königl. Preuss. Akad. Wiss. Berlin, :122, 1854, nomen nudum; Abh. Königl. Akad. Wiss. Berlin 1854, :151, 1855.

Begonia tovarensis Moritz ex Klotzsch, Abh. Königl. Akad. Wiss. Berlin 1854, :151, 1855. 1855

Begonia uliginosa Schott ex Klotzsch, Abh. Königl. Akad. Wiss. Berlin 1854, :155,

Begonia vellerea Klotzsch, Monatsber. Königl. Preuss. Akad. Wiss. Berlin, :122, 1854, nomen nudum; Abh. Königl. Akad. Wiss. Berlin 1854, :152, 1855.

Begonia tovarensis Klotzsch var. ocanensis A. DC., Prodr., 15(1):303, 1864.

Begonia lacustris Wright ex Grisebach, Cat. PI. Club., :117, 1866 pro syn.

Begonia uleiC. de Candolle, Bull. Herb. Boissier, II, 8:313, 1908.

Begonia cilibracteata C. De Candolle, Smithsonian Misc. Collect., 69(12):5: 1919.

Begonia kaietukensis Tutin, J. Bot., 78:250, 1940.

Begonia roraimensis Tutin, J. Bot., 78:251, 1940.

Begonia fischeri Schrank var. brasiliensis (Klotzsch) Irmsch., Bot. Jahrb. Syst., 76:24, pl. 1: fig. 4, 1953.

Begonia fischeri Schrank var. elata (Klotzsch) Irmsch., Bot. Jahrb. Syst., 76:24, pl. 1: fig. 3, 1953.

Begonia fischeri Schrank var. eufischeri Irmsch., Bot. Jahrb. Syst., 76:24, 98, 1953.

Begonia fischeri Schrank var. moritziana (Klotzsch) Irmsch., Bot. Jahrb. Syst., 76:24, pl. 2: fig. 1, 1953.

Begonia fischeri Schrank var. tovarensis (Klotzsch) Irmsch., Bot. Jahrb. Syst., 76:24, pl. 1: fig. 1, 1953.

Begonia populifolia auct. non Kunth in Humboldt, Bonpland \& Kunth: Liebmann, Vid. Medd. Naturh. F. Kjöbenhavn 1852, :16, 1853.

Begonia patula auct. non Hatworth: Klotzsch, Abh. Königl. Akad. Wiss. Berlin $1854,: 150,1855$.

(PRANCHA: fig.22: G-K, pág.57; MAPA: fig.21, pág.56) 
ERVAS delicadas, vilosas, tricomas simples, 0,3-1m alt. CAULES $(0,1-) 0,3-0,7 \mathrm{~cm}$ diâm., eretos, suculentos, cilíndricos a estriados, pouco ramificados, verdes a avermelhados, vilosos; entrenós 2-7(-8)cm comp. ESTÍPULAS 0,5-1cm comp., 0,3-0,5cm larg., lanceoladas, ápice mucronulado, raramente obtuso, base truncada, margem fimbriada, membranáceas, caducas, apressas, vilosas no dorso. FOLHAS com pecíolos $1-3 \mathrm{~cm}$ comp., estriados, vilosos; lâminas 2,5-6,5cm comp., 1,5-4cm larg., inteiras, basifixas, papiráceas, cordiformes a largamente obovais, assimétricas, ápice agudo, base cordada, lobos separados ou imbricados entre si, margem irregularmente serreada a crenada, ciliada, vilosas, tricomas simples em ambas as faces, face adaxial verde, face abaxial verde a rosada, venação actinódroma, 5-7 nervuras na base. CIMEIRAS 5-15 flores, 3-4 nós, vilosos, tricomas simples; brácteas 1 par, aprox. $5 \mathrm{~mm}$ comp., ca. $3 \mathrm{~mm}$ larg., ovais, ápice agudo, base truncada, margem fimbriada, persistentes, vilosas. FLORES ESTAMINADAS tépalas 4, as externas 0,6-0,8cm comp., 0,5-0,7cm larg., largamente elípticas a orbiculadas, ápice arredondado, base arredondada a subcordada, margem inteira, glabras, as internas 0,5-0,7cm comp., 0,2-0,3cm larg., ovais, ápice arredondado, base cuneada, margem inteira, glabras, alvas a róseas; pedicelos 0,5-1cm comp., vilosos; bractéolas 1-3 pares, 0,2-0,3cm comp., ca. $1 \mathrm{~mm}$ larg., ovais a espatuladas, ápice agudo, base truncada, margem fimbriada, persistentes, vilosas; estames 15-30, 3-4mm comp., filetes livres; anteras ca. $2 \mathrm{~mm}$ comp., rimosas, oblongas. FLORES PISTILADAS tépalas 5, semelhantes entre si, 0,3-0,5cm comp., 0,3-0,4cm larg., obovais, ápice arredondado, base truncada, margem inteira, glabras, alvas a róseas; pedicelos $0,5-1,5 \mathrm{~cm}$ comp., vilosos, tricomas simples; bractéolas 1-3 pares, 0,2-0,3cm comp., ca. $2 \mathrm{~mm}$ larg., ovais a espatuladas, ápice agudo, base truncada, margem fimbriada, uma inserida no pedicelo, logo abaixo do hipanto e as demais no ápice do pedicelo, persistentes, vilosas; estiletes ca. 2,5mm comp.; estigmas ca. $1 \mathrm{~mm}$ comp., ramos cilíndricos e espiralados; hipanto glabro. CÁPSULAS 0,1-2,5cm comp., 1,5-3,5cm larg., estiletes persistentes, tépalas e bractéolas caducas, região locular $0,5-0,8 \mathrm{~cm}$ diâm., placentas partidas; alas diferentes entre si, sendo a ala maior bastante ascendente; ala maior 1,5-1,8cm larg., ápice agudo; alas menores $0,2-0,5 \mathrm{~cm}$ larg. SEMENTES estreitamente elípticas.

DISTRIBUIÇÃO E HÁBITATS: Begonia fischeri é encontrada nas regiões Centra e Sul de Minas Gerais, no Vale do Jequitinhonha, Vale do Rio Doce, na Zona da Mata, Alto São Francisco e no Vale do Paranaíba, em áreas dominadas por campos, campos rupestres, Cerrado e pela Mata Atlântica, habitando tanto interiores quanto clareiras de matas úmidas, áreas alagadas ou temporariamente alagadas, floresta montana, matas de galerias, margens de córregos, áreas perturbadas e barrancos.

FLORAÇÃo E FRUTIFICAÇÃo: floresce de junho a dezembro e frutifica em março e de julho a dezembro.

COMENTÁRIOS: Begonia fischeri é uma erva delicada semi-heliófila, caracterizada pelo indumento viloso dos caules e pecíolos, pelas lâminas cordiformes a largamente obovais, fortemente assimétricas e pela ala maior das cápsulas ascendente com ápice agudo. Esta espécie é altamente polimórfica, o que induziu alguns botânicos a descreverem diferentes espécies e variedades para o táxon. Baseado no tamanho das folhas, 
indumento e tamanho dos tricomas, Irmscher (1953) reconheceu 13 variedades em Begonia fischeri, sendo elas: B. fischeri var. fischeri, B. fischeri Schrank var. brasiliensis (Klotzsch) Irmsch.; B. fischeri Schrank var. brevipilosa Irmsch.; B. fischeri Schrank var. crenato-glabra Irmsch.; B. fischeri Schrank var. crenulato-glabra Irmsch.; B. fischeri Schrank var. ermani (Klotzsch) Irmsch.; B. fischeri Schrank var. eufischeri Irmsch.; B. fischeri Schrank var. klugii Irmsch.; B. fischeri Schrank var. macroptera (Klotzsch) Irmsch.; B. fischeri Schrank var. malvacea (Klotzsch) Irmsch.; B. fischeri Schrank var. moritziana (Klotzsch) Irmsch.; B. fischeri Schrank var. palustris (Bentham) Irmsch. e B. fischeri Schrank var. tovarensis (Klotzsch) Irmsch. Já Golding \& Wasshausen (2002), reconhecem nove táxons infra-específicos para Begonia fischeri, utilizando a forma da lâmina como característica principal na separação desses táxons. Como os extremos de variação são muito discrepantes, verifica-se, portanto, uma grande dificuldade (ou mesmo impossibilidade) em se identificar materiais de Begonia fischeri ao nível de variedade e, como foram avaliados somente os espécimes de Minas Gerais e como também não foram analisados os tipos dos nomes em questão, não foi possível estabelecer um padrão dentro de toda a variabilidade morfológica de Begonia fischeri que permita sua correta identificação neste nível.

Begonia fischeri apresenta similaridades com Begonia alchemilloides Meissner ex A. DC. e com Begonia hirtella Link, diferenciando-se destas espécies, pelas características discutidas anteriormente em Begonia alchemilloides na tabela I, pág.18.

MATERIAL EXAMINADO: BRASIL. Minas GeraIs. Araponga, Parque Estadual da Serra do Brigadeiro. Estrada para a entrada do Parque, 23.III.2008, Delfini, C. 46, \& Paula-Souza, J. (ESA). Barão de Cocais, Lagoa das Antas, 30.III.1992, Brandão, M. 20910 (PAMG); Entrada da cidade - trevo, 12.XI.1991, Veríssimo, P. 542 (PAMG). Cambuquira, Mata da Empresa, 26.XII.1935, Barreto, M. 4036 (BHCB). Carandai, Crespo, III.1952, Duarte, A.P. 556, (RB). Conceição do Mato Dentro, Capitão Felizardo, XII.2001, Meyer, S. T. s.n., et al. (HXBH 14383). Coromandel, Córrego Bonito de Baixo (UHE/Bocaina número 1033), 4.XI.1988, Brandão, M. 15733 (PAMG). Coronel Pacheco, Fazenda da Liberdade, 27.XI.1944, Heringer, E.P. 1657 (RB); Fazenda da Barra, 15.I.1945, Heringer, E.P. 1725 (RB). Diamantina, 24.V.1955, Pereira, E. 1506 (RB). Fervedouro, Zona da Mata, 2.VIII.1992, Brandão, M. 19541 (PAMG). Governador Valadares, Fazenda EPAMIG, 20.IX.1987, Cunha, L.H.S. 1002 (PAMG). Inconfidentes, 14.X.1988, Leitão Filho, H.F. 20904, et al. (UEC). Itabira, Antigo condomínio da CVRD, 20.X.2005, Mota, R.C. 2959 (BHCB). Jacui, Fazenda São José. Mata, 4.XI.1978, Azevedo, A.M.G. 8576 (UEC). Lima Duarte, Parque Estadual do Ibitipoca. Estrada para a entrada do Parque, 18.I.2008, Delfini, C. 54, \& Tsuji, R. (ESA). Machado, Sul de Minas, 10.III.1950, Carcerelli, C. 5 (RB). Monte Belo, Mata higrófila 5, Fazanda Queimada Grande, 7.IX.1987, Gentry, A. 59144, et al. (UEC). Pampulha, 18.IX.1985, Buendia, L. 487 (PAMG). Passa Quatro, Estação Experimental M.I.N.P. Brejo, 2.V.1948, Brade, A.C. 18928, \& Araújo, S. (RB); Serra Fina, área do Ibama. Floresta Montana, 21.III.2008, Delfini, C. 40, \& Paula-Souza, J. (ESA). Pedro Leopoldo, Estrada BR 040, dentro d'água, 31.X.1990, Macedo, J.F. 1036 (PAMG). Ponte Nova, CETEC, X.1986, Alli, J.R.S. s.n. (BHCB 14410); Ponte Nova, Estação Experimental de EPAMIG, 23.III.1989, Rocha, L.B. 6 (VIC). Reduto, L.R. (Sítio do Dorico), 7.X.1944, Heringer, E.P. 1621 (RB). Santa Luzia, Estrada de Vesparziano, km18, 23.VII.1934, Barreto, M. 1846 (BHCB). Santa Rita, Bom Jardim, 4.VI.1989, Braga, M.M.N. s.n., \& Grandi, T.S.M. (BHCB 17552). Santos Dumont, Em brejo, 15.III.1957, Pereira, E. 2341 (RB). São Sebastião do Paraíso, Fazenda Calado, 16.IV.1945, Brade, A.C. 17578 \& Barbosa, A. (RB). Senador Bento, 16.VII.1999, Brandão, M. 29272 (PAMG). Sete Lagoas, Lago 9, 9.VII.1999, Macedo, J.F. 3460 (PAMG); Estação Experimental de Sete Lagoas, 9.IX.1969, Silva, J.B. 363 
(PAMG). Uberlândia, Estação Ecológica do PANGA Éden, 20.IX.2004, Arantes, A.A. 1372, \& Ranal, M. (HUFU). Viçosa, São José do Triunfo, sítio São José do Triunfo, estrada de terra a direita da Igreja, 14.XII.1992, Vieira, M.F. 740, \& Soares, M.F. (VIC); Paraíso, fazenda do Sr. Vicente Ferreira, 15.XII.1992, Vieira, M.F. 756, \& Soares, M.F. (VIC). Sem Município, Fazenda Santa Cruz Brumadinho, 11.XII.1997, Karam, C.M. 22 (BHCB); Sítio. Herbário do Museu Nacional, 6.XII.1905, Sampaio, A.J. 426 (RB).

MATERIAL ADICIONAL EXAMINADO: BRASIL. SÃo PaUlo. São Paulo, Ipiranga. Cultivada no Horto Botânico, II.1916, Luederwaldt, H., s.n. (SP 8757); Ipiranga. Em várzea, II.1912, Luederwaldt, H., s.n. (SP 8756). 


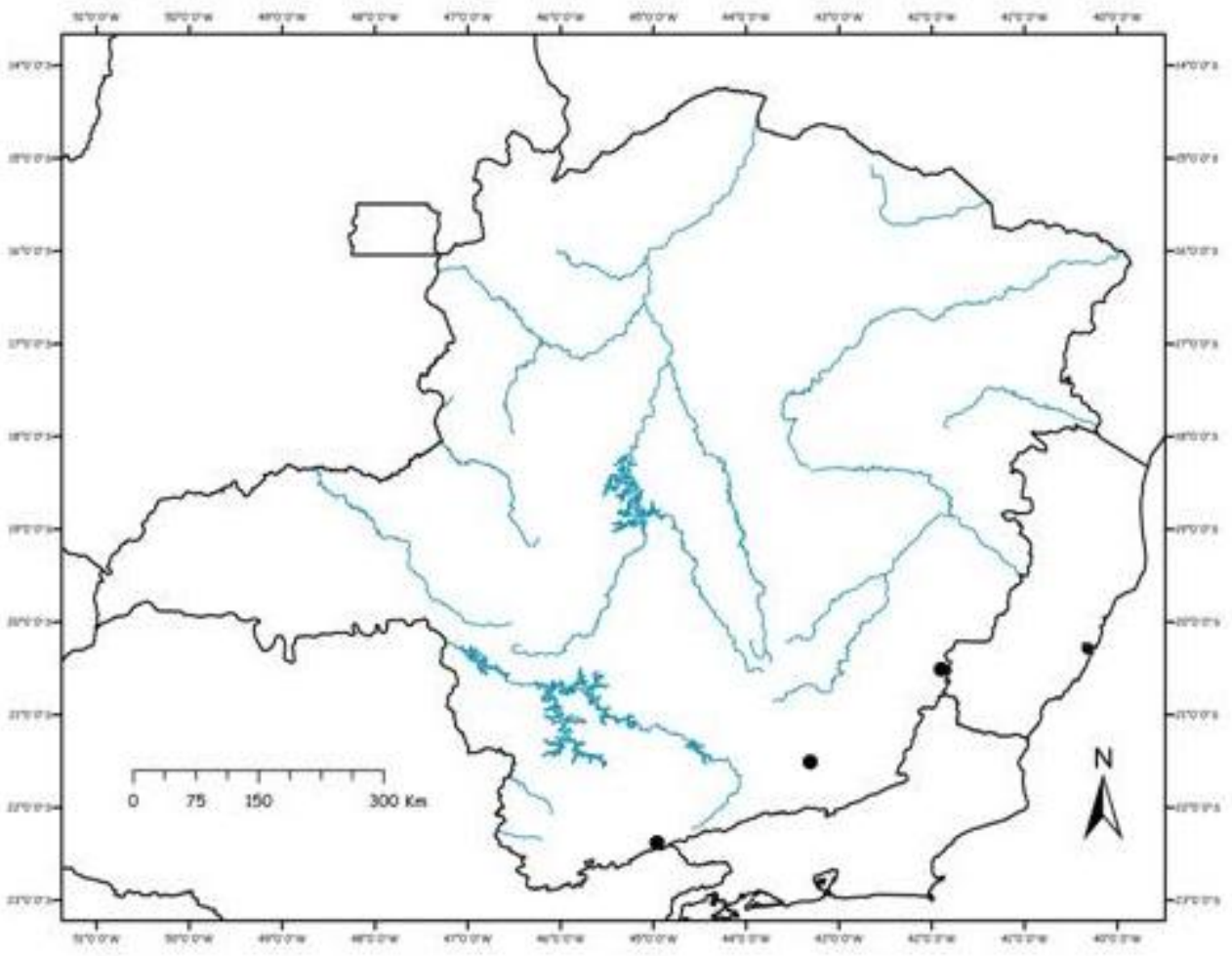

Figura 20: Mapa de distribuição geográfica de B. digitoto

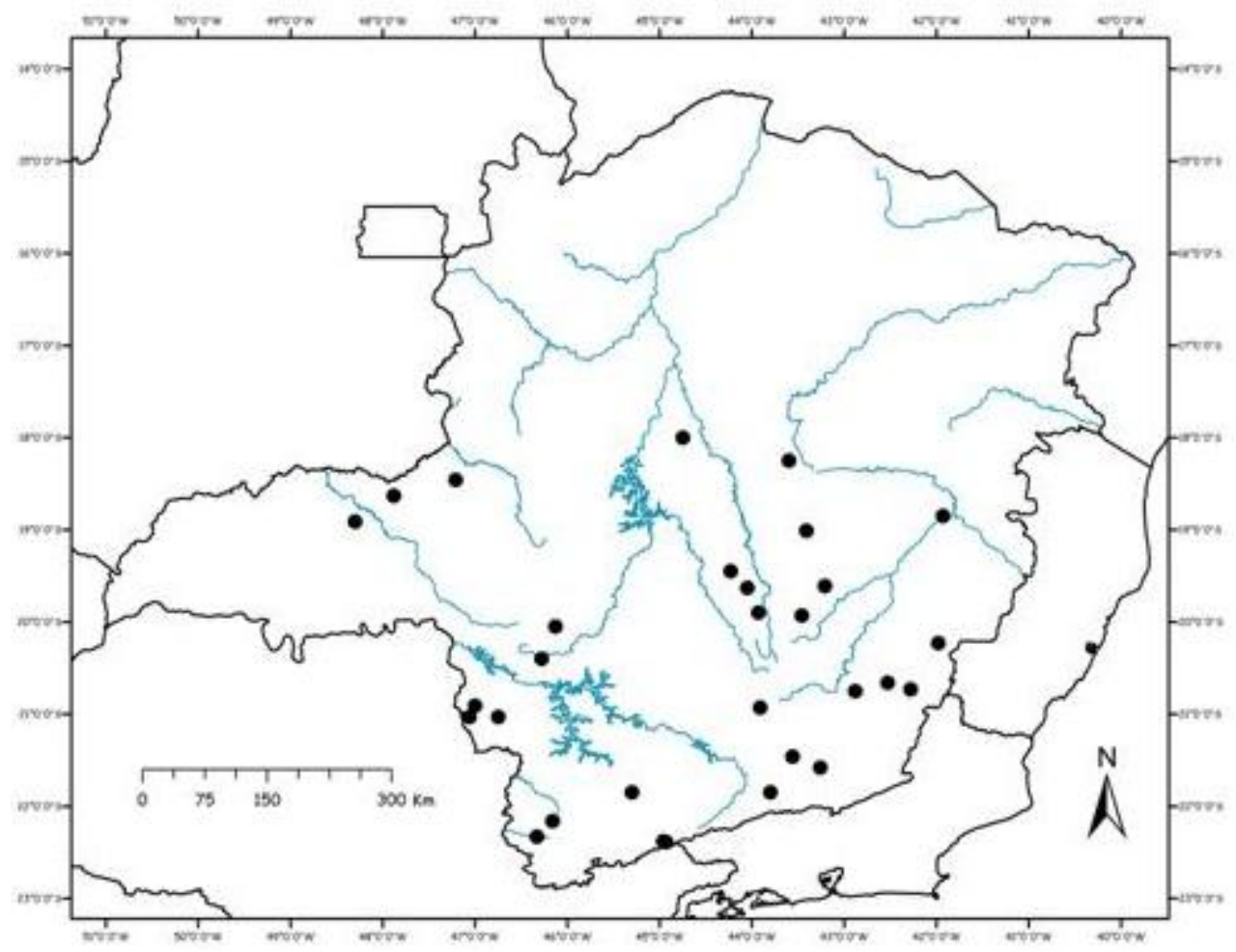

Figura 21: Mapa de distribuição geográfica de B. fischeri 


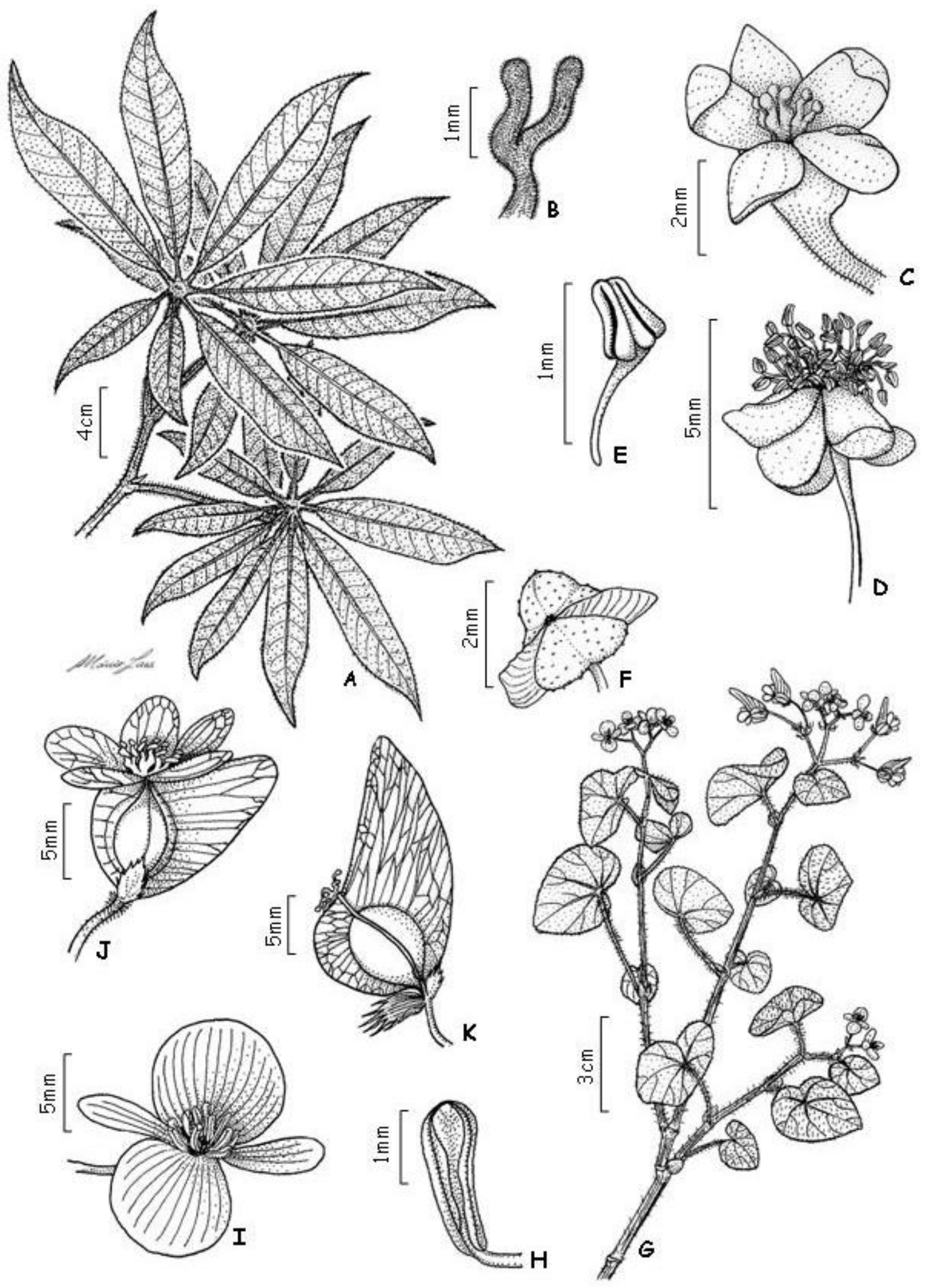

Figura 22: A-F: $\boldsymbol{B}$. digitata: A- hábito; B- estigma; $C$ - flor pistilada; D- flor estaminada; E- estame; F- cápsula. G-K: $\boldsymbol{B}$. fischerr: G- hábito; H- estame; I- flor estaminada; J- flor pistilada; K- cápsula; [ A: C. Delfini, 36 \& J. Paula-Souza (ESA); B-C: R.C. Forzza, 8109 et al (RB); D-E: G.J. Shepherd, 5767 et al (RB); F: R.C. Forzza, 8109 et d. (RB). G: M.F. Vieira, 740 \& M.F. Soares (VIC); H-I: C. Delfini, 40 \& J. Paula-Souza (ESA); J: C. Delfini, 46 \& J. Paula-Souza (ESA): K: C. Delfini, 40 \& J. Paula-Souza (ESA)]. 
4.4.11. Begonia fruticosa A. DC. in Martius, FI. bras. 4(1): 377, 1861.

Trendelenburgia fruticosa Klotzsch, Monatsber, Königl. Preuss. Akad. Wiss. Berlin, :123, 1854, nomen nudum; Abh. Königl. Akad. Wiss. Berlin 1854, :172, 1855.

Begonia castaneifolia auct. non Otto \& Dietrich: hort. Boissier ex A. DC, in Martius, FI. bras., 4(1):377, 1861, "castaneaefolid".

Begonia splendens hort. Boissier ex A. DC., in Martius, FI. bras., 4(1):377, 1861, pro syn.

(PRANCHA: fig.25: A-F, pág.63; MAPA: fig.23, pág.62)

SUBARBUSTOS trepadores a escandentes, glabros, pubérulos quando jovens, tricomas simples, 1,5-2m alt. CAULES 0,2-0,5cm diâm., trepadeiros a escandentes, sublenhosos, cilíndricos, estriados, muito ramificados, marrons, glabros; entrenós 0,5-4,3(-5,2)cm comp. ESTÍPULAS 0,4-1cm comp., 0,1-0,3cm larg., triangulares a lanceoladas, ápice mucronulado, base truncada, margem inteira, membranáceas, persistentes, apressas, pubérulas, glabrescentes. FOLHAS com pecíolos 0,2-0,5cm comp., cilíndricos, glabros; lâminas 4,5-8cm comp., 1,2-2,5cm larg., inteiras, basifixas, papiráceas, elípticas a ovais, simétricas a levemente assimétricas, ápice acuminado, base aguda a atenuada, margem serreada esparsamente ciliada, glabras em ambas as faces, face adaxial verde, face abaxial verde a avermelhada, peninérveas. CIMEIRAS 30-80 flores, 3-5 nós; pedúnculo 0,5-2cm comp., glabros; brácteas 1 par, 0,3-0,8cm comp., 0,1-0,2cm larg., triangulares a lanceoladas, ápice mucronulado, base truncada, margem inteira, persistentes, glabras. FLORES ESTAMINADAS tépalas 4, as externas 0,3-0,5cm comp., 0,2-0,3cm larg., ovais a obovais, ápice arredondado a obtuso, base truncada, margem inteira, glabras, as internas 0,2-0,5cm comp., 0,1-0,2 cm larg., elípticas a obovais, ápice obtuso a arredondado, base truncada, margem inteira, glabras, alvas a esverdeadas; pedicelos 0,2-0,5cm comp., glabros; bractéolas 1-3 pares, ca. $2 \mathrm{~mm}$ comp., ca. $1 \mathrm{~mm}$ larg., lanceoladas, ápice mucronulado, base truncada, margem inteira, persistentes, glabras; estames 10-20, aprox. 3mm comp., filetes livres; anteras ca. $1 \mathrm{~mm}$ comp., introrsas, elípticas a oblongas. FLORES PISTILADAS tépalas 5, semelhantes no tamanho e forma, reflexas, 0,2-0,4cm comp., aprox. $1 \mathrm{~mm}$ larg., lanceoladas, ápice obtuso a agudo, base truncada, margem inteira, glabras, alvas a esverdeadas; pedicelos 0,3-0,8cm comp., glabrescentes; bractéolas 1-3 pares, 0,2-0,3cm comp., ca. $1 \mathrm{~mm}$ larg., lanceoladas, ápice mucronulado, base truncada, margem inteira, inseridas no pedicelo, persistentes, glabras; estiletes 4-5mm comp.; estigmas c.a $3 \mathrm{~mm}$ comp., ramos cilíndricos e pouco espiralados, hipanto glabro. CÁPSULAS 0,5-1cm comp., 0,3-0,6cm larg., estiletes e bractéolas persistentes, tépalas caducas, região locular $0,3-0,5 \mathrm{~cm}$ diâm., placentas inteiras; alas semelhantes entre si, pouco desenvolvidas ou rudimentares, aprox. $1 \mathrm{~mm}$ larg. SEMENTES fusiformes.

DISTRIBUIÇÃO E HÁBITATS: Begonia fruticosa é encontrada nas regiões Central e Sul de Minas Gerais, no Vale do Jequitinhonha e na Zona da Mata, nos domínios da Mata Atlântica e Cerrado, habitando principalmente locais de maior altitude, tais como matas 
de altitude e encostas de serras; cresce sobre árvores ou entre rochas, atingindo cerca de $1 \mathrm{~m}$ alt. acima do solo e geralmente floresce em clareiras próximas ao dossel.

FLORAÇÃO E FRUTIFICAÇÃo: floresce de maio a outubro e frutifica em maio.

COMENTÁRIOS: Begonia fruticosa apresenta características únicas entre as espécies do gênero Begonia de Minas Gerais tais como o hábito subarbustivo trepadeiro, os pelos pecíolos curtos $(2-5 \mathrm{~mm})$, as folhas simétricas a levemente assimétricas, peninérveas e os frutos com alas pouco desenvolvidas semelhantes entre si ou rudimentares.

Begonia fruticosa apresenta similaridades morfológicas com Begonia convolvulacea (Klotzsch) A. DC. e Begonia integerrima Spreng., e as principais diferenças entre essas espécies estão apresentadas na tabela IV, pág.37.

MATERIAL EXAMINADO: BRASIL. MINAS GeraIs. Araponga, Parque Estadual da Serra do Brigadeiro. Trilha do Mucuri. 1300-1325 m.s.m., 23.III.2008, Delfini, C. 44, \& Paula-Souza, J. (ESA). Camanducaia, Monte Verde - Floresta de Altitude - Córrego do Cadete - Pedra da Onça, 20.X.2002, Meireles. L.D. 1204, et al. (UEC). Conceição do Mato Dentro, Parque Natural do Ribeirão do Campo, 1.VIII.2002, Mota, R.C. 1623, et al. (BHCB). Coronel Pacheco, Fazenda da Companhia, 24.VIII.1944, Heringer, E.P. 1530, (RB); Estação Experimental, 21.IX.1944, Heringer, E.P. 1660 (RB). Santa Maria do Salto, Fazenda Duas Barras, 23.VIII.2003, Lombardi, J.A. 5440, et al. (BHCB).

MATERIAL ADICIONAL EXAMINADO: BRASIL. RIO DE JANEIRO. Rio de Janeiro, Serra dos Órgãos - Pedra do Frade, 19.VII.1940, Brade, A.C. 16448, (BHCB). SÃo PaULO. Salesópolis, Estação Biológica de Boracéia. Estrada para barragem do Rio Claro, 3.IX.1994, Simão-Bianchini, R. 489, et al. (ESA). 
4.4.12. Begonia gardneri A. DC., Ann. Sci. Nat. Bot., IV, 11:138, 1859.

(PRANCHA: fig.25: G-L, pág.63; MAPA: fig.24, pág.62)

ERVAS carnosas, glabriúsculas, tricomas simples, aprox. $2 \mathrm{~m}$ alt. CAULES 0,5-1cm diâm., eretos, suculentos, estriados, simples, verdes, tricomas esparsos; entrenós $2-2,5 \mathrm{~cm}$ comp. ESTÍPULAS 1-2cm comp., 0,5-1cm larg., ovais, ápice agudo, base truncada, margem inteira, membranáceas, persistentes, apressas, glabras. FOLHAS com pecíolos 6,5-13cm comp., estriados, tricomas esparsos; lâminas 10-17,5cm comp., 16-2cm larg., palmatilobadas, 4-6palmatífidas, incisões profundas, mas não ultrapassando a metade da distância entre a margem e o ponto de irradiação das nervuras, basifixas, papiráceas, transversais, depresso ovaladas, assimétricas, lobos triangulares com ápices agudos, base cordada, margem irregularmente serreada, glabras em ambas as faces, porém com indumento distribuído muito esparsamente nas nervuras na face abaxial, verdes em ambas as faces, palmatinérvea, 4-6 nervuras na base. CIMEIRAS ca. 100 flores, 5-6 nós; pedúnculos (9-)11-22cm, glabros; brácteas 1 par, 1-2mm comp., ca. 0,5mm larg., triangulares, ápice mucronulado, base truncada, margem inteira, caducas, glabras. FLORES ESTAMINADAS tépalas 4, as externas aprox. 0,5cm, ca. $3 \mathrm{~mm}$ larg., obovais, ápice agudo a obtuso, base arredondada, margem inteira, glabras, as internas ca. $0,4 \mathrm{~cm}$ comp., 0,1-0,2mm larg., obovais, ápice obtuso, base aguda, margem inteira, glabras, alvas a róseas; pedicelos aprox. $7 \mathrm{~mm}$ comp., tricomas esparsos; bractéolas 1-3 pares, ca. $2 \mathrm{~mm}$ comp., $1 \mathrm{~mm}$ larg., triangulares, ápice agudo, base truncada, tardiamente caducas, glabras; estames 15-25, ca. $4 \mathrm{~mm}$ comp., filetes livres; anteras 2-3mm comp., rimosas, oblongas. FLORES PISTILADAS tépalas 5, semelhantes entre si, aprox. $6 \mathrm{~mm}$ comp., 2$3 \mathrm{~mm}$ larg., elípticas, ápice agudo, base aguda, margem inteira, alvas a róseas; pedicelos 0,5-1,5cm comp., tricomas esparsos; bractéolas 1-3 pares, aprox. $2 \mathrm{~mm}$ comp., ca. $1 \mathrm{~mm}$ larg., triangulares, ápice agudo, base truncada, margem inteira, um par inserido logo abaixo do hipanto e os demais no pedicelo, tardiamente caducas, glabras; estiletes 1$1,5 \mathrm{~cm}$ comp.; estigmas ca. $1 \mathrm{~mm}$ comp., cilíndricos e espiralados, hipanto glabro. CÁPSULAS 0,5-1 cm comp., 1,5-2,5cm larg., tépalas, estiletes e bractéolas caducos, região locular ca. $0,5 \mathrm{~cm}$ comp., placentas inteiras; alas diferentes entre si, sendo a ala maior levemente ascendente; ala maior 1,5-2cm comp., ápice obtuso; alas menores ca. $1 \mathrm{~mm}$ comp. SEMENTES oblongas.

DISTRIBUiçÃo E HÁBITATS: Begonia gardneri é uma espécie endêmica do Estado de Minas Gerais, encontrada na região Central, no Vale do Rio Doce, na Zona da Mata e Alto São Francisco, em áreas dominadas pela Mata Atlântica e por campos rupestres, habitando preferencialmente interiores de matas, matas decíduas, locais temporariamente alagados, bordas de matas úmidas e entre rochas.

FLORAÇÃO E FRUTIFICAÇÃO: floresce nos meses de agosto e setembro e frutifica no mês de setembro.

COMENTÁRIOS: Begonia gardneri é uma planta umbrófila caracterizada pelas folhas palmatífidas, com incisões profundas, mas não ultrapassando a metade da distância 
entre a margem e o ponto de irradiação das nervuras. Em alguns casos, Begonia gardneri pode ser confundida com Begonia reniformis Dryand. ou com Begonia platanifolia Schott, sendo distinta dessas espécies pelas características apresentadas na tabela VIII abaixo:

Tabela VIII: Características diagnósticas entre Begonia gardneri, Begonia reniformis e Begonia platanifolia.

\begin{tabular}{|c|c|c|c|}
\hline & B. gardneri & Begonia reniformis & B. platanifolia \\
\hline Indumento & $\begin{array}{l}\text { glabriúsculas, } \\
\text { tricomas } \\
\text { simples }\end{array}$ & $\begin{array}{l}\text { tomentosas, } \\
\text { tricomas } \\
\text { simples }\end{array}$ & $\begin{array}{c}\text { tomentosas, } \\
\text { tricomas simples e tricomas } \\
\text { glandulares }\end{array}$ \\
\hline Forma das folhas & depresso ovaladas & reniforme & reniforme \\
\hline $\begin{array}{l}\text { Incisões } \\
\text { das folhas }\end{array}$ & $\begin{array}{l}\text { profundas, não } \\
\text { ultrapassando a } \\
\text { metade da distância } \\
\text { entre a margem e o } \\
\text { ponto de irradiação } \\
\text { das nervuras }\end{array}$ & $\begin{array}{l}\text { incisões } \\
\text { superficiais }\end{array}$ & $\begin{array}{c}\text { profundas, } \\
\text { não ultrapassando } \\
\text { a metade da distância } \\
\text { entre a margem e o ponto de } \\
\text { irradiação das } \\
\text { nervuras }\end{array}$ \\
\hline $\begin{array}{l}\text { Margem das } \\
\text { folhas }\end{array}$ & $\begin{array}{l}\text { irregularmente } \\
\text { serreada }\end{array}$ & $\begin{array}{l}\text { irregularmente } \\
\text { denticulada }\end{array}$ & $\begin{array}{c}\text { irregularmente } \\
\text { ondulada }\end{array}$ \\
\hline Estípulas & $\begin{array}{c}\text { persistentes, ovais, } \\
\text { com ápice agudo, } \\
\text { glabras }\end{array}$ & $\begin{array}{l}\text { caducas, triangulares, } \\
\text { com ápice agudo } \\
\text { a acuminado, glabras }\end{array}$ & $\begin{array}{c}\text { caducas, ovais a triangulares, } \\
\text { com ápice agudo a acuminado, } \\
\text { tomentosas }\end{array}$ \\
\hline Sementes & oblongas & obovais & oblongas \\
\hline
\end{tabular}

MATERIAL EXAMINADO: BRASIL. Minas GeraIs. Caparaó, Parque Nacional do Caparaó, Vele Verde, 2.VIII.1992, Hatschbach, G. 57140 (MBM). Caratinga, Matão, Estação Biológica de Caratinga, 22.IX.1995, Andrade, P.M. 699, \& Lopes, M.A. (ESA). Estação Biológica de Caratinga, fazenda Montes Claros, trilha do matão, 29.VIII.1994, Lombardi, J.A. 610, (BHCB, SP). Ferros, Entre Ferros e Viamão, Zona da Mata, 17.IX.1950, Duarte, A.P. 3082, (RB). Governador Valadares, Campo de sementes. Mata, 7.IX.1943, Magalhães, M. 2882, (RB); Campo de sementes, 7.IX.1943, Magalhães, M. 2883, (BHCB); Santo Hipólito, Estrada Corinto-Conselheiro Mata, a $6 \mathrm{~km} E$ de Santo Hipólito. Mata descídua sobre grande afloramento de calcário dominada por angicos (Leguminosae) e aroeiras (Astronium urundeuva), com grandes gameleiras (Ficus calyptroceras) e palmeiras (Chorisia sp.), 4.IV.1996, Pirani, J.R. 3754, et al. (ESA). 


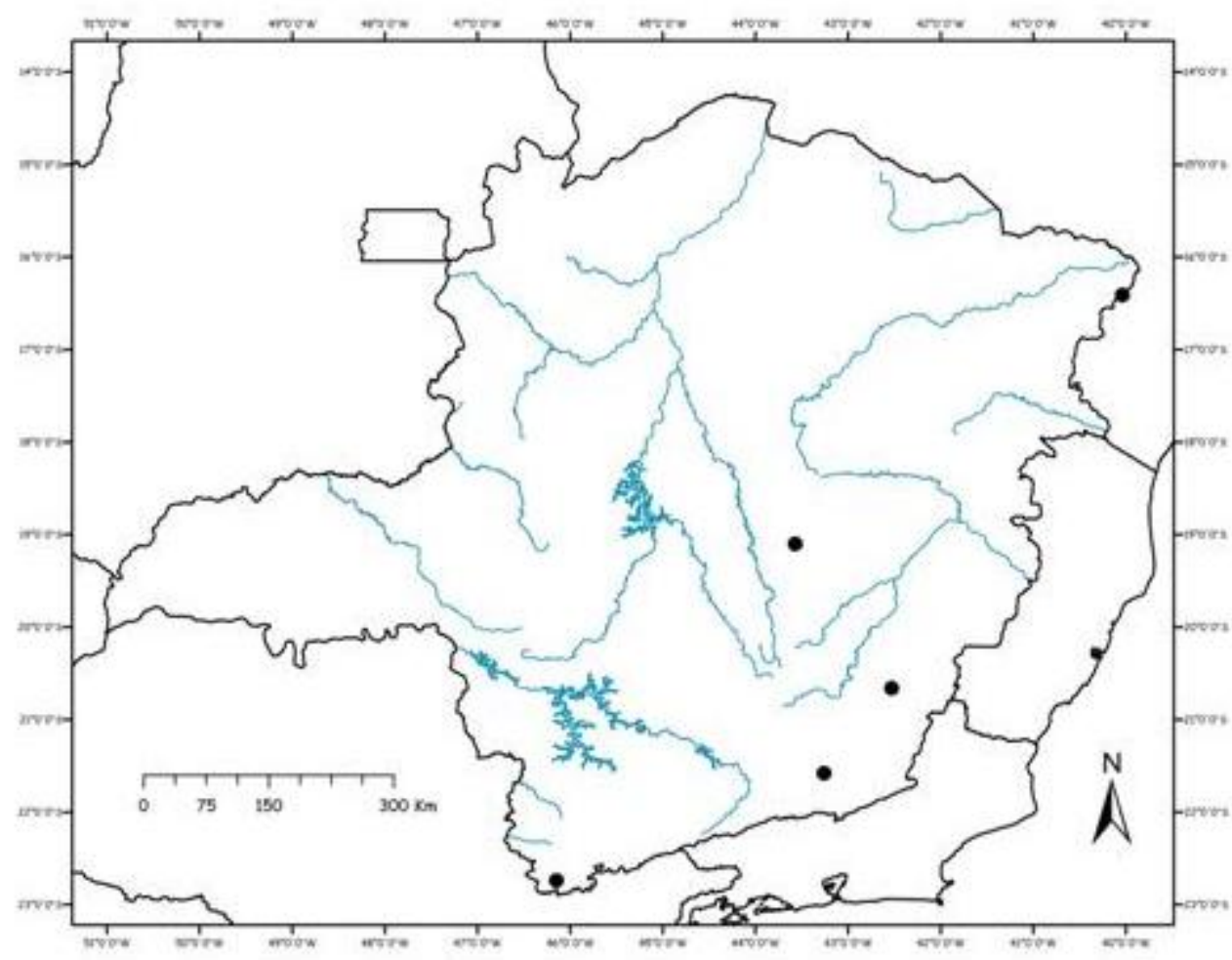

Figura 23: Mapa de distribuição geográfica de B. fruticosa

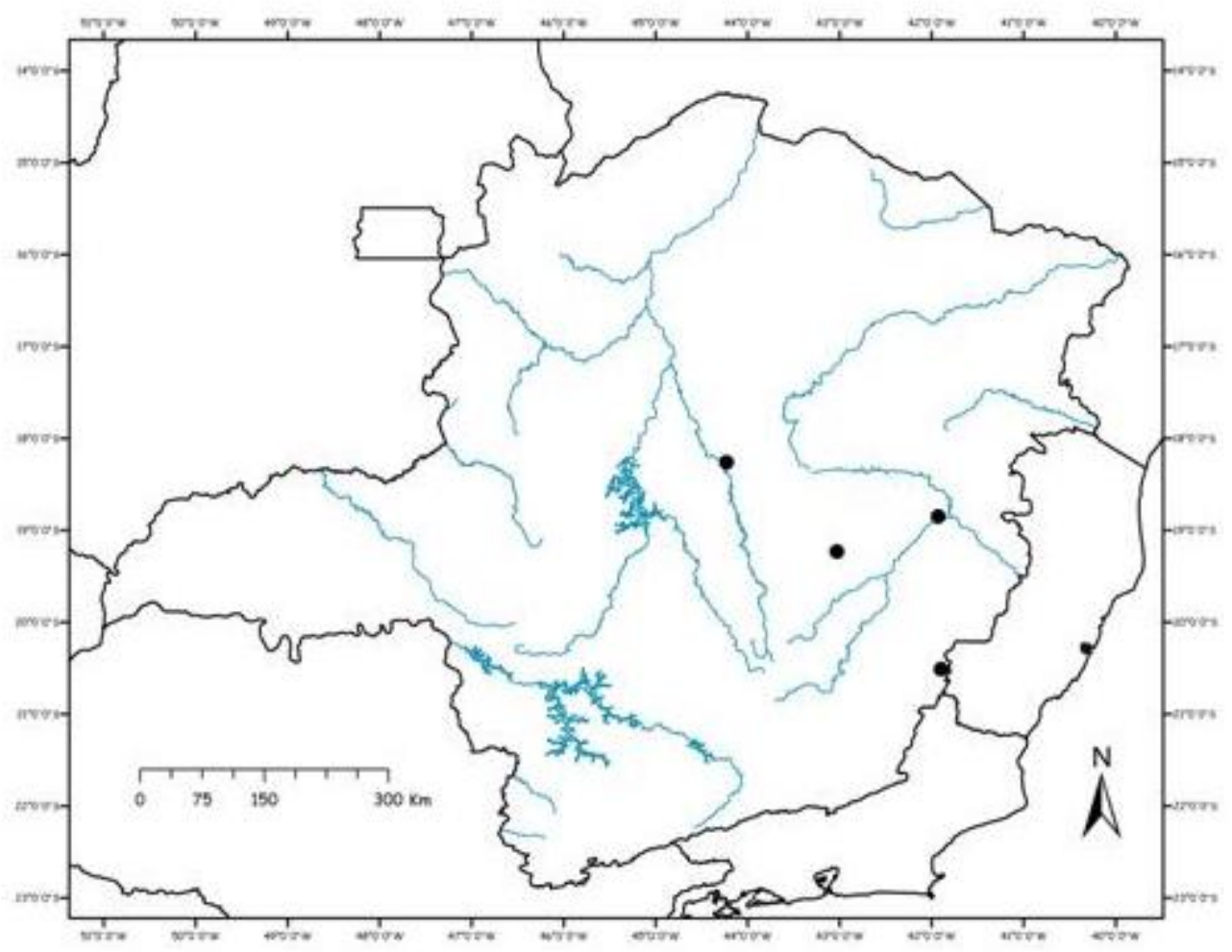

Figura 24: Mapa de distribuição geográfica de B. goroheri 


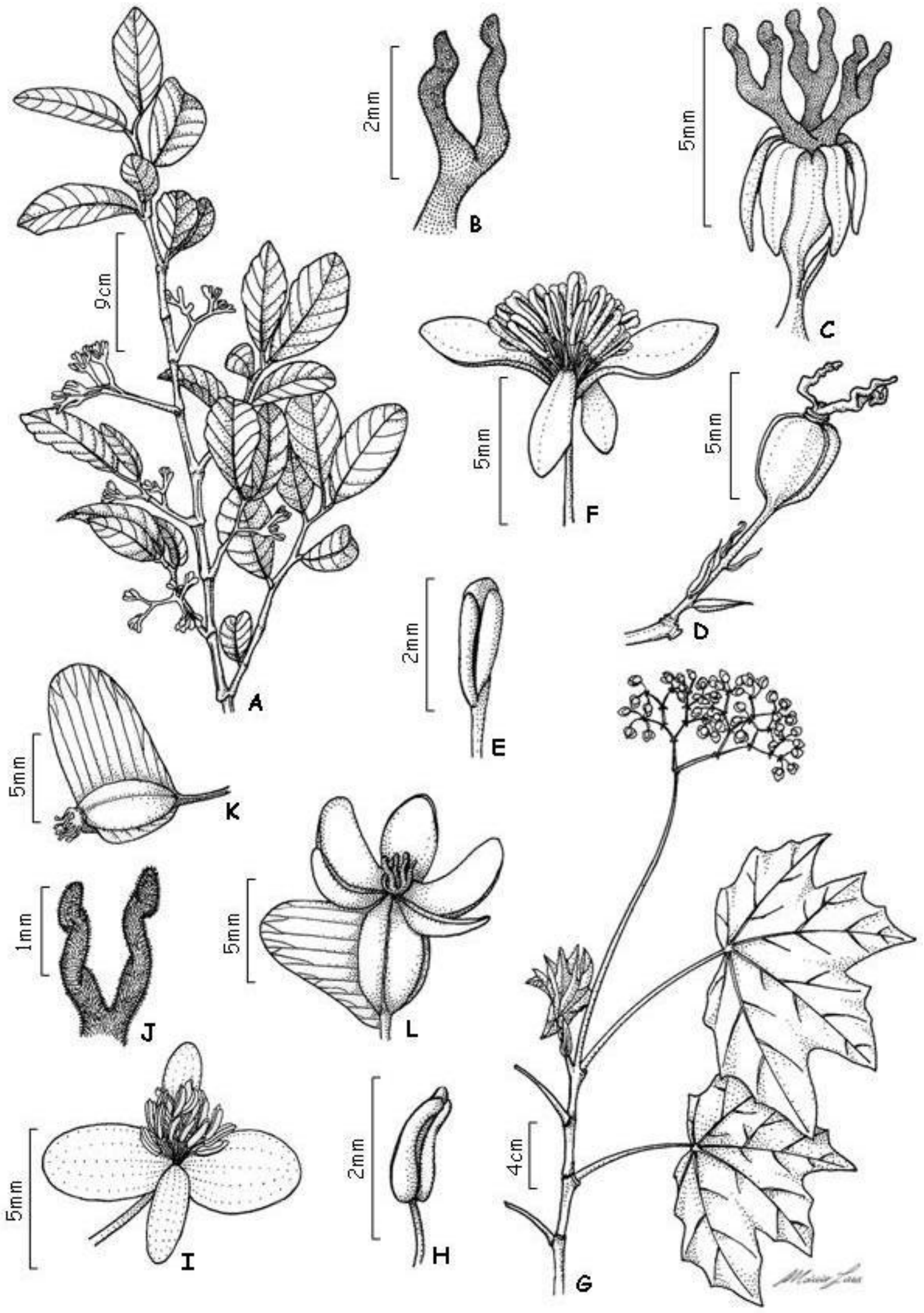

Figura 25: A-F: B. fruticosa A- hábito; B- estigma; $C$ - flor pistilada; D- cápsula; Eestame; F- flor estaminada. G-L: $\boldsymbol{B}$. gardheri G- hábito; H- estame; I- flor estaminada; J- estigma; K- cápsula; L- flor pistilada. [A: C. Delfini, 36 \& J. Paula-Souza (ESA); B-D: R. Simão-Bianchini, 489 et al (BHCB); E: A.C. Brade, 16448 (BHCB). G:J.A. Lombardi, 610 (BHCB); H-I: G. Hatschbach, 57140 (MBM) J-L: M. Maqalhães, 2883 (BHCB)]. 
4.4.13. Begonia grisea A. DC., Ann. Sci. Nat. Bot., IV, 11:138, 1859.

Begonia ragozini Schwacke, PI. Nov. Mineiras, 2:4, pl. 3, 1900.

(PRANCHA: fig.28: A-F, pág.70; MAPA: fig.26, pág.69; FOTO: fig.29, pág.71)

ERVAS tomentosas, tricomas estrelados, 0,4-2m alt. CAULES 0,4-1,4cm diâm., eretos, subcarnosos, cilíndricos a estriados, simples ou pouco ramificados, verde-cinéreos, glabrescentes; entrenós 0,5-4(-6,3)cm comp. ESTÍPULAS 2,5-4cm comp., 1,5-2,3cm larg., triangulares, ápice mucronulado, base truncada, margem inteira, membranáceas, caducas, apressas, tricomas estrelados no dorso. FOLHAS com pecíolos 2,5-8,5(-11)cm comp., cilíndricos a estriados, tomentosos; lâminas 4-8,1cm comp., 5,5-13,5cm larg., inteiras, basifixas, cartáceas, largamente elípticas a largamente ovais, levemente assimétricas, ápice geralmente não distinto, base profundamente cordada, margem irregularmente ondulada, tomentosas a glabrescentes em ambas as faces, sendo o indumento mais denso na face abaxial, face adaxial verde a cinérea, face abaxial verde a avermelhada, venação actinódroma, 6-10 nervuras na base. CIMEIRAS 50-200 flores, 47 nós; pedúnculos 12-46,5cm comp., tomentosos a glabrescentes; brácteas 1 par, $1-1,5 \mathrm{~cm}$ comp., 0,6-1,2cm larg., elípticas, ápice agudo, base truncada, margem inteira, caducas, tomentosas, indumento recobrindo todo o dorso. FLORES ESTAMINADAS tépalas 2 , 0,4-1,1 cm comp., 0,4-0,9cm larg., ápice arredondado a obtuso, base arredondada a subcordada, margem inteira, com tricomas no ápice do pedicelo, alvas a róseas; pedicelos 0,2-1 cm comp., com tricomas estrelados no ápice; bractéolas 1-2 pares, ca. de $3 \mathrm{~mm}$ comp., ca. $1 \mathrm{~mm}$ larg., estreitamente elípticas, ápice mucronulado, base truncada, margem inteira, caducas, com tricomas no dorso; estames 10-30, 4mm comp., filetes livres, anteras $1 \mathrm{~mm}$ comp., rimosas, elípticas a oblongas. FLORES PISTILADAS tépalas 5 , sendo uma delas ligeiramente desigual no tamanho e forma, 0,4-0,7cm comp., 0,3-0,7cm larg., estreitamente elípticas, ápice obtuso a agudo, base truncada, margem inteira, com tricomas no ápice do pedicelo, alvas a róseas; pedicelos 0,5-1cm comp.; bractéolas 1-2 pares, ca. $3 \mathrm{~mm}$ comp., ca. $1 \mathrm{~mm}$ larg., estreitamente elípticas, ápice agudo, base truncada, margem inteira, inseridas no pedicelo, caducas, com tricomas no dorso; estiletes aprox. $4 \mathrm{~mm}$ comp.; estigmas aprox. $2 \mathrm{~mm}$ comp., com ramos cilíndricos e espiralados, hipanto glabro. CÁPSULAS 0,5-1,1cm comp., 0,7-1,4cm larg., estiletes persistentes, tépalas e bractéolas caducas, região locular $0,4-0,7 \mathrm{~cm}$ diâm., placentas inteiras, alas desenvolvidas, semelhantes entre si, sendo uma ala pouco maior e levemente ascendente, ala maior 0,4-0,6cm larg., ápice arredondado, alas menores 0,2-0,4cm larg. SEMENTES oblongas.

DISTRIBUIÇÃO E HÁBITATS: Begonia grisea é uma erva rupícola, heliófila, encontrada nas regiões Central e Norte de Minas Gerais, Vale do Jequitinhonha, Vale do Mucuri e Alto São Francisco, em áreas dominadas por campos, campos rupestres, Cerrado, Caatinga e Mata Atlântica (em menor escala), habitando preferencialmente afloramentos rochosos e fendas de rochas.

FLORAÇÃO E FRUTIFICAÇÃO: floresce e frutifica praticamente o ano todo. 
COMENTÁRIOS: Begonia grisea apresenta características únicas das espécies de Begonia de Minas Gerais pelo indumento formado por tricomas estrelados, caules bem marcados pelas cicatrizes das estípulas, pelos entrenós curtos, pelas flores estaminadas com duas tépalas - embora nos espécimes Calió, M.F.A. 20, et al. e Stehmann, J.R. 2794, et al., foi observado algumas flores estaminadas jovens com quatro tépalas - e pelas alas dos frutos semelhantes entre si.

Begonia grisea apresenta similaridades morfológicas com Begonia ruhlandiana e podem ser prontamente diferenciadas pelo aspecto geral das folhas, sendo Begonia grisea com folhas largamente elípticas a largamente ovais e ápice geralmente não distinto, contrapondo folhas ovais e ápice agudo, raramente obtuso. Além disso, até o presente momento, só existem registros de coleta de Begonia ruhlandiana para o Estado da Bahia.

MATERIAL EXAMINADO: BRASIL. MINAS GERAIS. Buenópolis, Serra do Cabral, entrada de Buenópolis, 27.VII.1976, Davis, P. 2280, et al. (UEC). Congonhas do Norte, Serra Talhada. Fazenda Vereda do Cambota, alto da Serra do João Camilo, 6,8km sudoeste da estrada Congonhas do Norte-Gouveia, estrada a $3,7 \mathrm{~km}$ noroeste de Congonhas do Norte. Grandes afloramentos rochosos com lajeados planos, 19.I.2004, Calió, M.F.A. 20, et al. (RB, SPF). Conselheiro Mata, estrada Guinda, Conselheiro da Mata, km 178, 4.VI.1985, Leitão Filho, H.F. 17333, et al. (UEC). Cristália, Morro do Chapéu, 6.I.1986, Kameyama, C. s.n., et al. (SPF 41072); Morro da Antena de Televisão. Afloramento rochoso com cerrado adjacente, 12.VII.2001, Souza, V.C. 25778 , et al. (ESA). Diamantina, 20-26km de Diamantina, caminho de Conselheiro Mata, MG220. Campo rupestre com importantes afloramentos rochosos quartzíticos (iselbergs), 18.V.1990, Arbo, M.M. 4369, et al. (SPF); Estrada para Conselheiro Mata, $\mathrm{km} \mathrm{182,} \mathrm{em} \mathrm{afloramento} \mathrm{rochoso,}$ 13.VII.1996, Atui, J.P. 6, et al. (ESA); para Conto de Magalhães., 22.XI.1964, Duarte, A.P. 8547, (RB); Extração, 3.IV.1985, Menezes, N.L. S.n., \& Meguro, M. (SPF 43031); Gruta do Salitre, 22.II.2003, Romão, G.0. 944, et al. (ESA); 9km de Diamantina, em direção a Curvelo, 6.VII.1996, Souza, V.C. 12016, et al. (ESA); Biribiri, Gruta do Salitre, 14.II.2001, Stehmann, J.R. 2794, et al. (BHCB); Estrada para Conselheiro Mata, 500m do asfalto, 27.I.1986, Wagner, H.L. s.n., et al. (SPF 41668). Gouveia, Serra do Espinhaço, 6.IX.1971, Hatschbach, G. 27304 (MBM); Serra do Espinhaço, 13.XI.1971, Hatschbach, G. 27890, \& Pelanda, P. (MBM). Grão Mogol, ca. 5-15km ao norte da cidade. Colaboração IBUSP, Universidade de São Paulo (SPF) e R.B.G. Kew (K) Patrocínio do National Geographic Society., 16.X.1988, Harley, R.M. 25131, et al. (SPF); Ao norte de Grão Mogol, pedras quartzíticas., 27.XI.1984, Harley, R.M. S.n., et al. (SPF 36110); arredores de Minas, 22.VII.1978, Hatschbach, G. 41563, (MBM); arredores de Minas., 12.VI.1990, Hatschbach, G. 54155, et al. (MBM); Serra de Grão Mogol., 17.VIII.1960, Maguire, B. s.n., et al. (RB 126287); Serra de Grão Mogol, nos rochedos, 12.XI.1938, Markgraf 3483, et al. (RB); Rio temporário a leste da cidade, estrada para o Rio Ventania., 25.VII.1986, Mello-Silva, R. s.n., et al. (SPF 43851); Estrada do Barão. Serra do Barão, ca. 500-2000m da cidade. Campo rupestre e encostas rochosas quartzíticas, 15.V.1998, Pirani, J.R. 4331, et al. (SPF); Jambeiro, a $7 \mathrm{~km}$ de Grão Mogol, 5.IX.1985, Pirani, J.R. S.n., et al. (SPF 39823); Estreito do Riacho Ribeirão, 6.IX.1990, Pirani, J.R. s.n., et al. (SPF 69613); Serraria, 11.III.1999, Rapini, A. 736, \& Kawasaki, M.L. (SPF). Itacambira, Serra de Itacambira, 5.X.1990, Brandão, M. 18995, (PAMG); Serra de Itacambira - Ponto 9, 23.III.1993, Brandão, M. 22215, (PAMG); $5 \mathrm{~km}$ de Itacambira a leste da cidade, na estrada para Montes Claros, 29.XI.1984, Kawasaki, M.L. s.n., et al. (BHCB 59664, SPF 36223); Estrada Itacambira - Juramento, ca. $9 \mathrm{~km}$ de Itacambira, 23.II.2002, Souza, V.C. 28278, et al. (ESA). Itacarambi, Serra de Itacarambi, 13.III.1991, Brandão, M. 18428, (PAMG). 
Jequitinhonha, Serra de Areia, ca. $47 \mathrm{~km}$ ao sul de Pedra Azul, na estrada para Jequitinhonha, 20.X.1988, Harley, R.M. 25243, et al. (SPF). Joaquim Felício, Serra do Cabral, 28.VII.1976, Davis, P. 2407, et al. (UEC); Serra do Cabral, entre os rios Embalassasia e Rio Preto, 18.VIII.2002, Hatschbach, G. 73476, et al. (MBM); Serra do Cabral, 20.IX.2005, Hatschbach, G. 79362, \& Barbosa, E. (MBM); Serra do Cabral - Estrada Joaquim Felício, várzea da Palma, ca. $12 \mathrm{~km}$ de Joaquim Felício, 9.VII.2001, Souza, V.C. 25556, et al. (ESA). Presidente Kubitschek, Estrada Conceição do Mato Dentro - Diamantina Km 433, 15.XII.1985, Souza, V.C. s.n., et al. (SPF 40884). Rio Vermelho, Pedra Menina. Platô Pedra Menina, 9.IX.1986, Mello-Silva, R. s.n., et al. (SPF 44724). Santana do Riacho, Serra do Cipó, 24.X.1997, Forzza, R.C. 355, \& Marcato, A.C. (SPF). Santo Antônio do Itambé, início da estrada para o Pico do Itambé, 12.III.1995, Souza, V.C. 8364, et al. (ESA, MBM). Serro, Pico do Itambé. Campo, 5.V.1942, Magalhães, M. 2125, (RB). Sem Município, divisa entre os municípios de Espinosa e Montezuma, $35 \mathrm{~km}$ do Pau d'Arco, 15.III.1994, Roque, N. s.n., et al. (ESA 23496, SPF 97482). 
4.4.14. Begonia heringeri Brade, Arq. Jard. Bot. Rio de Janeiro, 13:177, pl. 4, 1954. Tipo: Brasil. Minas Gerais. Fazenda do Sertão, Rodovia Coronel Pacheco - Juiz de Fora, Heringer 1737, III/1945 (Holótipo: RB!, Isótipos: RB!).

(PRANCHA: fig.28: G-H, pág.70; MAPA: fig.27, pág.69)

SUBARBUSTO delgado, tomentoso, tricomas simples, barbados, até $1 \mathrm{~m}$ alt. CAULES $1-$ $4 \mathrm{~mm}$ diâm., suberetos, subcarnosos, cilíndricos, estriados, ramificados, marrons, glabrescentes; entrenós 2,5-5cm comp. ESTÍPULAS 1-1,5cm comp., ca. $3 \mathrm{~mm}$ larg., elípticas, ápice acuminado, base truncada, margem inteira, membranáceas, tardiamente caducas, apressas, com uma crista de tricomas no dorso. FOLHAS com pecíolos 0,52,5cm comp., cilíndricos, estriados, glabrescentes; lâminas 4,5-8,5cm comp., 1,2-2,5cm larg., inteiras, basifixas, membranáceas, oblongas a elípticas, levemente assimétricas, ápice acuminado, base assimétrica, margem serreado-dentada, esparsamente ciliada, glabras em ambas as faces, indumento esparso, distribuído somente sob a nervura principal, verdes em ambas as faces, venação peninérvea. CIMEIRAS até 50 flores, 3-4 nós; pedúnculos 3-7cm comp., glabrescentes; brácteas 1 par, ca. $1,3 \mathrm{~cm}$ comp., aprox. $4 \mathrm{~cm}$ larg., oblongas, ápice acuminado, base truncada, margem inteira, caducas, glabrescentes. FLORES ESTAMINADAS (jovens) tépalas 4, as externas ca. $6 \mathrm{~mm}$ comp., aprox. $5 \mathrm{~mm}$ larg., ovais, ápice arredondado, base arredondada, margem inteira, glabrescentes, as internas ca. $6 \mathrm{~mm}$ comp., 2-3mm larg., elípticas, ápice obtuso, base aguda, margem inteira, glabrescentes, alvas; pedicelos ca. $5 \mathrm{~mm}$ comp., glabrescentes; bractéolas 1-3 pares, ca. $1 \mathrm{~cm}$ comp., 4-5mm larg., elípticas, ápice obtuso, base truncada, margem inteira, tardiamente caducas, glabrescentes; estames 20-25, ca. 3mm comp., filetes livres; anteras 1-2mm comp., rimosas, oblongas. FLORES PISTILADAS [tépalas 5 , diferentes entre si, 6-7mm comp., 2,5-3mm larg., ovais-lanceoladas], ápice e base não vistos, [margem ondulada, glabrescentes], alvas; pedicelos comp. não visto, [pubérulo]; bractéolas 1-3 pares, [3,5-4mm comp., 3-3,2 mm larg.], forma, ápice, base e margem não vistos, um par inserido abaixo do hipanto e os demais no pedicelo, tardiamente caducas, glabrescentes; estiletes [ca. 3,2mm comp.]; estigmas comp. não visto, [ramos cilíndricos e espiralados], hipanto não visto. CÁPSULAS 0,7-0,9cm comp., 1,5-2cm larg., estiletes persistentes, tépalas e bractéolas caducos, região locular $5-7 \mathrm{~mm}$ diâm., placentas inteiras; alas diferentes entre si, sendo a ala maior levemente ascendente; ala maior 0,8-1 cm larg., ápice obtuso a arredondado; ala menor 1-2 mm larg. SEMENTES oblongas.

DISTRIBUIÇÃO E HÁBITATS: Begonia heringeri é uma espécie endêmica do Estado de Minas Gerais, encontrada na Zona da Mata, em áreas dominadas pela Mata Atlântica, habitando locais úmidos e sombreados e encostas rochosas.

FLORAÇÃO E FRUTIFICAÇÃo: floresce nos meses de janeiro e março e frutifica no mês de janeiro.

COMENTÁRIOS: Begonia heringeri é um subarbusto caracterizado pelos caules delgados, pelo indumento tomentoso formado por tricomas simples e tricomas barbados, pelas estípulas elípticas e pelas folhas peninérveas. De acordo com a descrição original, 
Begonia heringeri possui similaridades morfológicas com Begonia bonitoensis Brade, podendo ser prontamente diferenciadas pelo fato desta última apresentar estípulas caducas e revestimento nos caules e nas folhas. Além disso, até o presente momento, só existem registros de coleta de Begonia bonitoensis para o Estado do Rio de Janeiro.

O número reduzido de materiais analisados de Begonia heringeri indica que esta espécie está subamostrada em termos de coleta $e$, de acordo com os critérios estabelecidos pela IUCN (2001), Begonia heringeri é classificada como uma espécie provavelmente extinta, por não haver registros de novas coletas desde 1945.

MATERIAL EXAMINADO: BRASIL. MINAS GeraIs. Coronel Pacheco, Fazenda do Sertão, rodovia Coronel Pacheco - Juiz de Fora, 13.III.1945, Heringer, E.P. 1737 (RB); Segunda coleta no mesmo local, 14.III.1945, Heringer, E.P. 1737A (VIC); Fazenda do Sertão, rodovia Coronel Pacheco Juiz de Fora, 17.I.1945, Heringer, E.P. 1737 (RB); Rodovia Juiz de Fora, Fazenda do Sertão, 17.I.1945, Heringer, E.P. 1737C, (VIC). 


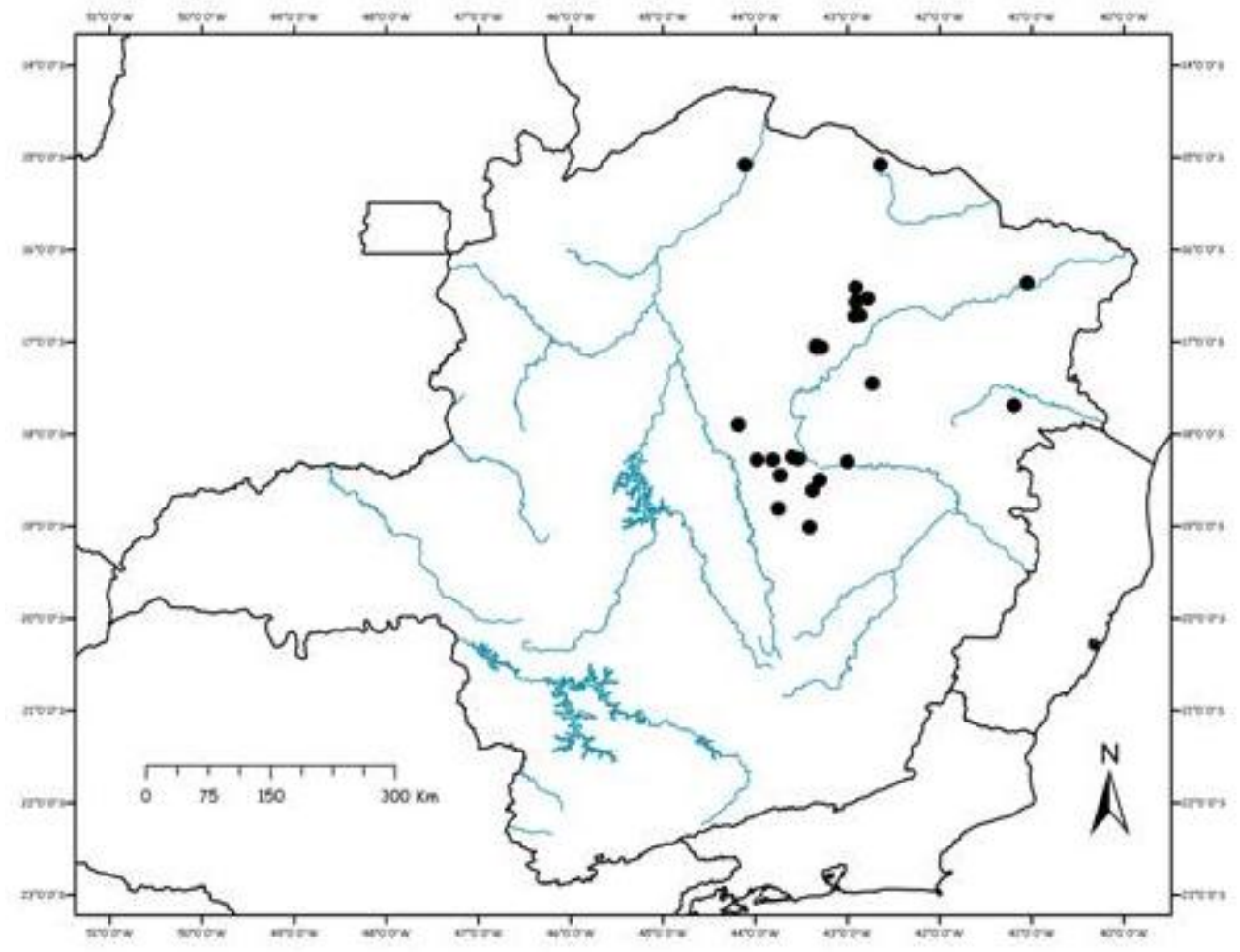

Figura 26: Mapa de distribuição geográfica de B. griseo

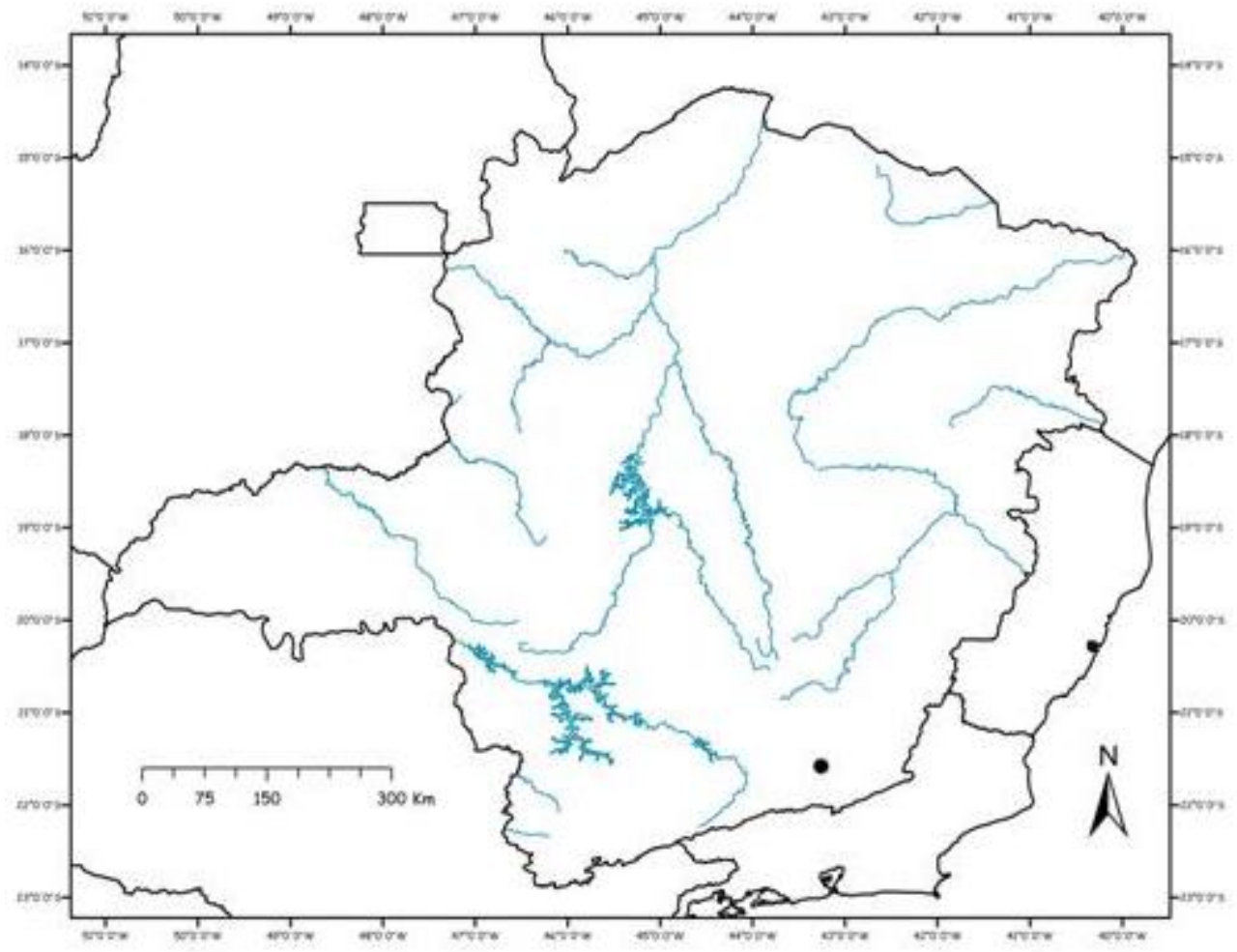

Figura 27: Mapa de distribuição geográfica de B. heringeri 


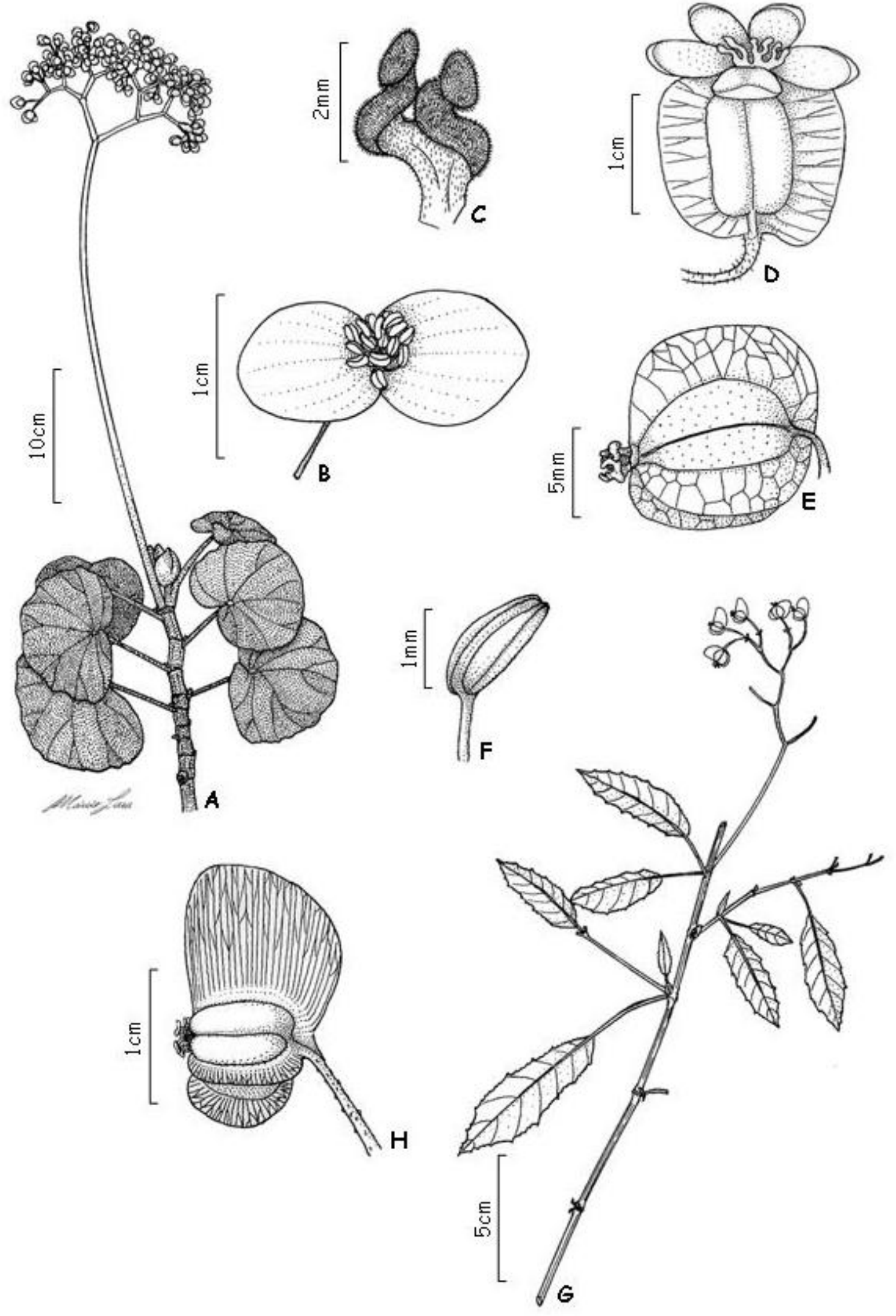

Figura 28: A-F: B. grisea A- hábito; B- flor estaminada; C- estigma; D- flor estaminada; E- cápsula; F- estame. G-H: $\boldsymbol{B}$. heringeri G- hábito; H- cápsula. [A-B: J.R. Pirani, 4331 et al (SPF); C-D: V.C. Souza, 25556 et al. (ESA); E: J.R. Pirani, s.n. et al (SPF 39823); F: J.R. Pirani, 4331 et al (SPF). G-H: E.P. Heringer, 1737 (RB)]. 


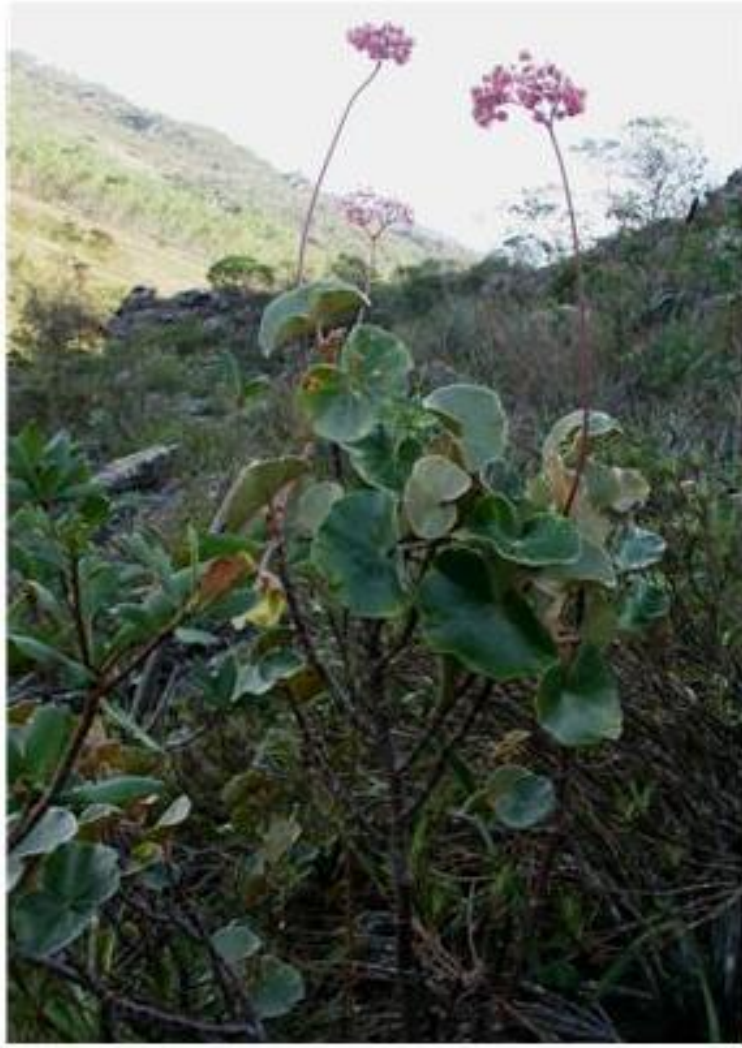

Figura 29: B. grisea hábito

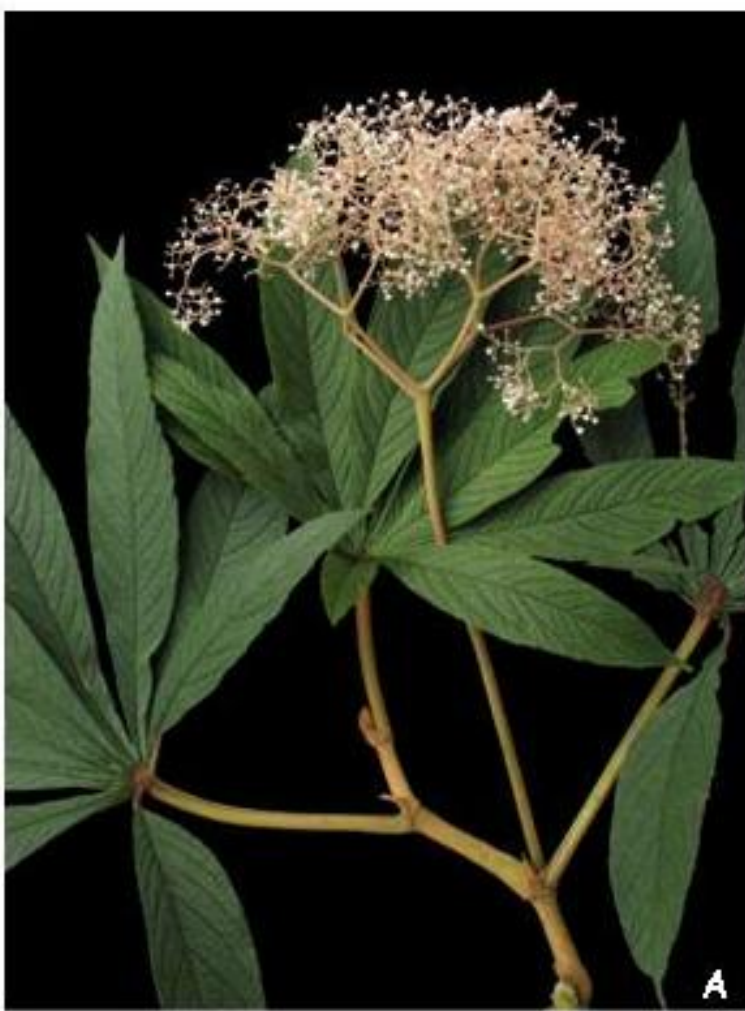

Figura 31: B. hoxurions: A- ramo; B- detalhe das flores estaminadas; $\mathbf{C}$ - detalhe da cápsula.

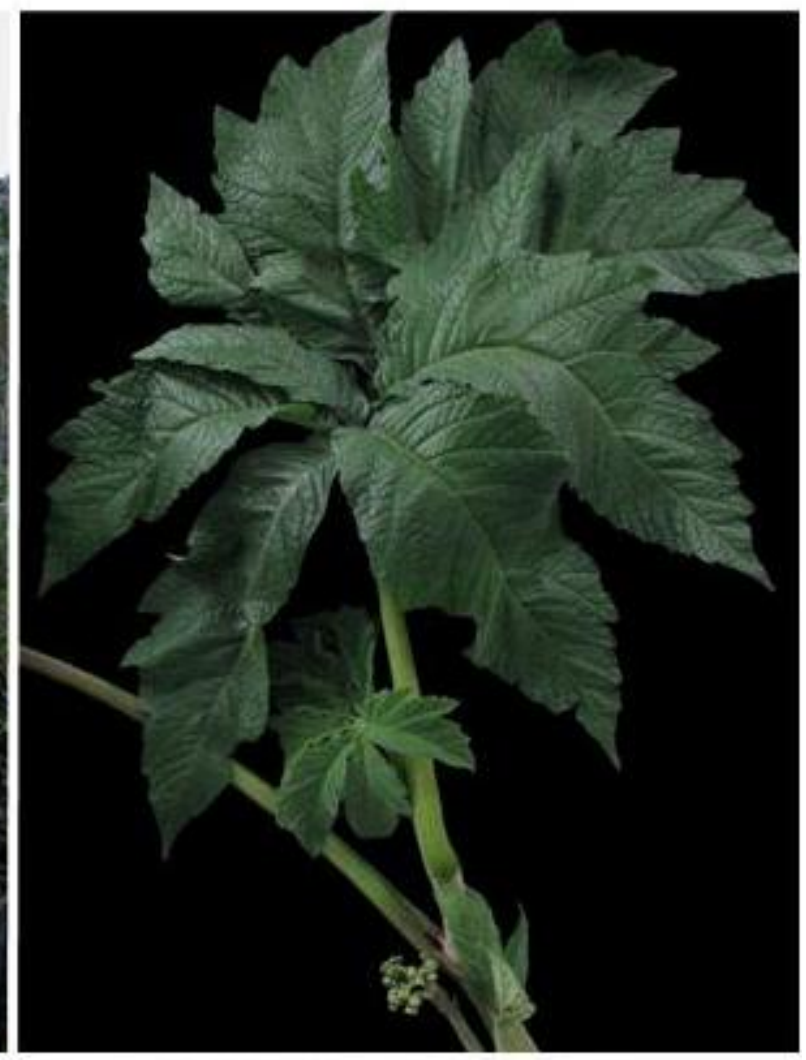

Figura 30: B. incisoserrota. ramo

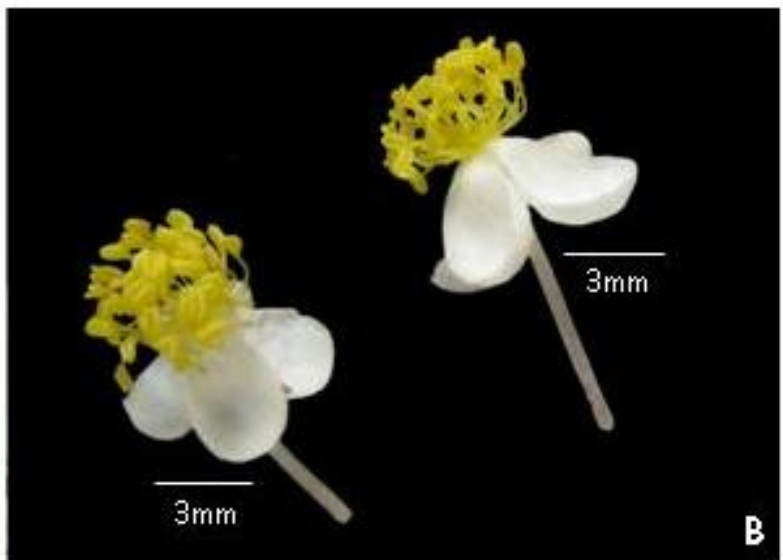

c

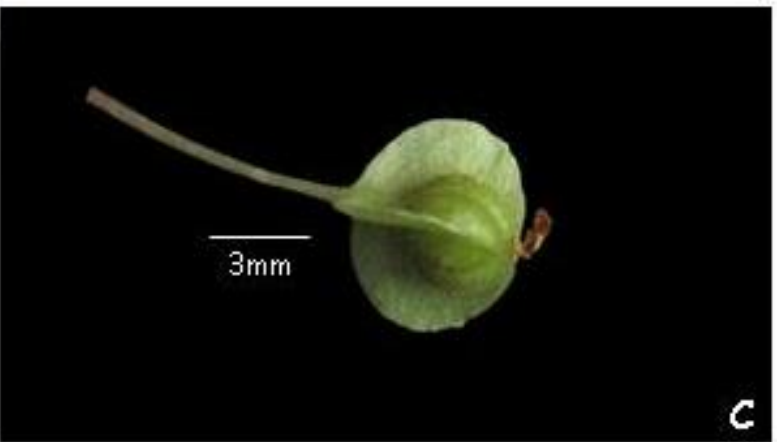


4.4.15. Begonia hirtella Link, Enum. Hort. Berol., 2:396, 1822.

Begonia ciliata Kunth in Humboldt, Bonpland \& Kunth, Nov. Gen. Sp., 7:folio 136, quarto 178, 1825.

Begonia villosa Lindley, Edwards's Bot. Reg., 15:pl. 1252, 1829.

Begonia brasilia A. DC., Mem. Soc. Phys. Geneve, 7:295, 1836, non Jard. Geneve 34.

Begonia brasiliana Schrank ex Steudel, Nom. Bot. ed 2, 1193, 1840. nomen nudum. Begonia albido-setulosa Hasskarl, Hasskarl, Hort. Bogor. Descr., :313, 1858.

Begonia dasypoda Meissner ex A. DC., in Martius, FI. bras., 4(1):345, 1861, pro syn.

Begonia humilis auct. non. Dryander: Duss, FI. Phan. Antil. France, 2:321, 1897.

(PRANCHA: fig.34: A-F, pág.77; MAPA: fig.32, pág.76)

ERVAS delicadas, vilosas, tricomas simples e glandulares, $30-60 \mathrm{~cm}$ alt. CAULES $2-5 \mathrm{~mm}$ diâm., eretos, suculentos, estriados, simples a pouco ramificados, verdes a avermelhados, glabrescentes; entrenós (2,5-)4-7,5cm comp. ESTÍPULAS 0,-1,2cm comp., 0,3-0,6cm larg., elípticas a ovais, ápice obtuso a arredondado, base truncada, margem fimbriada, membranáceas, persistentes, apressas, glabras. FOLHAS com pecíolos 0,8-3,4cm comp., estriados, glabrescentes; lâminas (4-)5-7,7cm comp., (2-)2,5$4,5 \mathrm{~cm}$ larg., inteiras, basifixas, membranáceas, oblíquas a transversais, ovais, assimétricas, ápice agudo, base cordada, margem irregularmente serrilhada, ciliada, glabrescentes, face adaxial verde, face abaxial verde a avermelhada, venação actinódroma, 5-6 nervuras na base. CIMEIRAS 5-20 flores, 1-3 nós; pedúnculos 2,5cm comp., tricomas simples esparsos; bráctea 1-2 pares, 4-5mm comp., 1-2 mm larg., elípticas a ovais, ápice geralmente agudo, base truncada, margem fimbriada, persistentes, glabras. FLORES ESTAMINADAS tépalas 4 , as externas ca. $7 \mathrm{~mm}$ comp., aprox. $5 \mathrm{~mm}$ larg., largamente obovais, ápice arredondado, base arredondada, margem inteira, geralmente com tricomas glandulares, as internas ca. $5 \mathrm{~mm}$ comp., aprox. $1 \mathrm{~mm}$ larg., obovais, ápice obtuso a arredondado, base aguda, margem inteira, glabras, alvas a róseas; pedicelos ca. $1 \mathrm{~cm}$ comp., glabros ou com tricomas glandulares; bractéolas 1-3 pares, 3-4mm comp., 2-3mm larg., obovais a elípticas, ápice geralmente obtuso, base truncada, margem fimbriada, persistentes, glabras ou com tricomas glandulares; estames 10-20, 3-4mm comp., filetes livres; anteras 1-2mm comp., rimosas, oblongas. FLORES PISTILADAS tépalas 5, semelhantes entre si, ca. $7 \mathrm{~mm}$ comp., 1-2 mm larg., elípticas a obovais, ápice obtuso a arredondado, base truncada, margem inteira, geralmente com tricomas glandulares, alvas a róseas; pedicelos 0,5-1cm comp., glabros ou com tricomas glandulares; bractéolas 1-3 pares, 3-4mm comp., 2-mm larg., obovais a elípticas, ápice geralmente obtuso, base truncada, margem fimbriada, um par inserido no hipanto e os demais no pedicelo, persistentes, glabras ou com tricomas glandulares; estiletes ca. $2 \mathrm{~mm}$ comp.; estigmas ca. $1 \mathrm{~mm}$ comp., ramos cilíndricos e espiralados, hipanto glabro ou com tricomas glandulares. CÁPSULAS $1(-1,5) \mathrm{cm}$ comp., $2-2,5 \mathrm{~cm}$ larg., bractéolas e estiletes persistentes, tépalas caducas, região locular ca. $6 \mathrm{~mm}$ diâm., placentas partidas; alas diferentes entre si, sendo a maior levemente ascendente; ala 
maior 0,5-1cm larg., ápice arredondado a obtuso; alas menores 0,3-0,5cm larg. SEMENTES oblongas.

DISTRIBUIÇÃO E HÁBITATS: Begonia hirtella é encontrada nas regiões Central, Norte e Sul de Minas Gerais, na região Metropolitana de Belo Horizonte, nas Vertentes, no Vale do Rio Doce, na Zona da Mata e no Vale do Paranaíba, nos domínios da Mata Atlântica, Cerrado, campos rupestres e Caatinga, habitando locais úmidos e sombreados, matas de galerias, entre rochas e em locais com vegetação arbustiva mais densa.

FLORAÇÃO E FRUTIFICAÇÃO: floresce de janeiro a março, em maio e de agosto a setembro e frutifica de janeiro a março e de agosto a setembro.

COMENTÁRIOS: Begonia hirtella é uma espécie frequentemente confundida com Begonia fischeri Schrank e com Begonia alchemilloides Meissner ex A. DC., sendo prontamente diferenciadas pelas características apresentadas na tabela I, pág.18.

$\mathrm{Na}$ Flora Brasiliensis, De Candolle reconhece duas variedades para Begonia hirtella. B. hirtella var. hirtella e B. hirtella var. nana A. DC., sendo esta última caracterizada pelo menor e pelas inflorescências paucifloras, entretanto, Jacques (2002) considerou como sinônimos estes dois táxons, uma vez que a variabilidade observada é intrínseca à espécie e o mesmo foi observado nos materiais analisados de Minas Gerais.

Material eXaminado: BRASIL. Minas Gerais. Caeté, Serra da Piedade, 4.III.1976, Ferreira, M.B. 5498 (PAMG); Serra da Piedade, 28.IV.1985, Lobato, P. 1720, et al. (BHCB); Serra da Piedade, 28.IV.1985, Maciel, P.L. s.n., et al. (SP 263351); Serra da Piedade, 13.VIII.1985, Paiva, J.A. 2 (SP, BHCB). Catas Altas, Serra do Caraça, 5.I.2005, Mota, R.C. 2648 (BHCH). Itabirito, Pico do Itabirito, 17.II.1995, Teixeira, W.A. s.n. (BHCB 26295). Januária, Vale do rio Peruaçu, Boqueirão da Onça, 24.V.1997, Salino, A. 3092 (BHCB). Lavras, 13.IX.1941, Black 51B (ESAL). Nova Lima, 7.VI.1994, Meyer s.n., et al. (HXBH 11115). São Roque de Minas, Parque Nacional da Serra da Canastra - Nascente do Córrego do Barbaro, 24.VIII.1997, Nakajima, J.N. 2800, et al. (HUFU). Tiradentes, Serra de São José. Bosque Mãe d'Água. Mata de Cerrado, 23.XII.1987, Alves, R.J.V. 149 (RB). Tombos, Fazenda São Pedro. Habitat sujo, 2.V.1941, Oliveira, J.E. 305 (RB). Uberlândia, Reserva Ecológica do PANGA, 11.IX.1987, Barbosa, A.A.A. s.n. (ESA 102862); Estação Ecológica do Panga, 3.VI.1999, Ranal, M. 754 (HUFU). Viçosa, Fazenda da Crissiuma, 26.II.1935, Kuhlmann s.n. (VIC 2433)

MATERIAL ADICIONAL EXAMINADO: BRASIL. RIO DE JANEIRO. Nova Iguaçu, 28.VIII.1987, Brandão, M. 13073 (PAMG); Rio de Janeiro, Jardim Botânico do Rio de Janeiro, s.d., Brandão, M. 16706 (PAMG). 
4.4.16. Begonia hugelii (Klotzsch) A. DC. in Martius, FI. bras., 4(1):366, 1861.

Wageneria hugelii Klotzsch in append. Gen. \& Sp. Herb. Berol, :2, 1855.

(PRANCHA: fig.34: G-L, pág.77; MAPA: fig.33, pág.76)

ERVAS robustas, escabrosa, indumento formado tricomas simples, curtos de base larga, tricomas finos e por escamas, até $2 \mathrm{~m}$ alt. CAULES (0,5-)1-2cm diâm., eretos, suculentos, estriados, simples, verdes, escabros; entrenós $1,5-3 \mathrm{~cm}$ comp. ESTÍPULAS $1-1,5 \mathrm{~cm}$ comp., 0,5-1cm larg., triangulares, ápice mucronulado, base truncada, margem levemente ondulada, membranáceas, caducas, apressas, escabras. FOLHAS com pecíolos (4-)4,513(-28)cm comp., estriados, escabros; lâminas (19-)23-50cm comp. 10,5-35cm larg., inteiras, basifixas, papiráceas, reniformes, levemente lobadas, assimétricas, ápices agudos, base cordada, margem irregularmente ondulada a irregularmente crenada, glabrescentes, sendo o indumento mais concentrado na face abaxial e sob as nervuras, verdes em ambas as faces, venação actinódroma, 5-7 nervuras na base. CIMEIRAS 200500 flores, 6-8 nós; pedúnculos (16,5-)22,5-41,5cm comp., glabrescentes; brácteas 1 par, 0,7-1cm comp., 5-8mm larg., triangulares, ápice agudo, base truncada, margem inteira, caducas, escabras. FLORES ESTAMINADAS tépalas 4, as externas 4-5mm comp., ca. 0,7cm larg., largamente elípticas a orbiculares, ápice arredondado, base arredondada, margem inteira, escabras e com glândulas salientes, as internas 4-5mm, 2$3 \mathrm{~mm}$ larg. obovais, ápice obtuso a arredondado, base truncada, margem levemente ondulada, glabras, com glândulas salientes distribuídas na região central das tépalas, alvas; pedicelos 2-5mm comp., escabros; bractéolas 1 par por nó, ca. $7 \mathrm{~mm}$ comp., 3-5mm larg., triangulares, ápice mucronulado, base truncada, margem levemente ondulada, caducas, escabras; estames 15-25, ca. $4 \mathrm{~mm}$ comp., filetes livres; anteras aprox. $3 \mathrm{~mm}$ comp., rimosas, oblongas. FLORES PISTILADAS tépalas 4, subiguais, sendo uma delas levemente desigual na forma, 3-4mm comp., 2-3mm larg., elípticas a ovais, ápice obtuso, base truncada, margem irregularmente ondulada, ciliada, glabras, com glândulas salientes, alvas; pedicelos 2-5mm comp., escabros; bractéolas 1 par por nó, ca. $7 \mathrm{~mm}$ comp., 2-5mm larg., triangulares, ápice mucronulado, base truncada, margem levemente ondulada, inseridas nos nós das inflorescências, caducas, escabras; estiletes ca. $3 \mathrm{~mm}$ comp.; estigmas aprox. $2 \mathrm{~mm}$ comp., ramos cilíndricos e espiralados, hipanto escabro. CÁPSULAS 0,5-1cm comp., 0,9-1,7cm larg., estiletes persistentes, tépalas e bractéolas caducos, região locular 3-5cm diâm., placentas inteiras; alas diferentes entre si, sendo a maior levemente ascendente; ala maior 0,5-1cm larg., ápice obtuso; alas menores 1-2 $\mathrm{mm}$ larg. SEMENTES oblongas.

DISTRIBUIÇÃO E HÁBITATS: ocorre na região Central de Minas Gerais e na Zona da Mata, em áreas dominadas pela Mata Atlântica, habitando locais sombrios, áreas alagadas ou temporariamente alagadas e bordas de matas.

FLORAÇÃO E FRUTIFICAÇÃO: floresce no período de maio a julho e frutifica em junho e em outubro. 
COMENTÁRIOS: Begonia hugelii é uma erva robusta caracterizada principalmente pelo indumento escabroso formado por tricomas e escamas e pelas flores pistiladas com 4 tépalas. Esta espécie apresenta similaridades morfológicas com Begonia hispida Schott e, segundo Smith et al. (1986), elas podem ser prontamente diferenciadas pelo fato desta última apresentar ambas as faces das folhas revestidas na maturidade. Entretanto, observou-se que esta característica pode ser variável e a face abaxial das folhas de Begonia hugelii pode apresentar-se glabrescente na maturidade. Outras características diagnósticas destas espécies são o tipo de indumento (escabroso em Begonia hugelii e hirsuto em Begonia hispida) e brácteas triangulares em Begonia hugelii, contrapondo brácteas lineares ou oblongas em Begonia hispida.

Material examinado: BRASIL. Minas GeraIs. Alto Caparaó, Parque Nacional do Caparaó. Vale verde. Trilha ao lado da área de lazer, 25.III.2008, Delfini, C. 34, \& Paula-Souza, J. (ESA); Vale Verde. Em lugar sombrio, 3.IX.1970, Souza, A.B. 104, \& Márcia (RB). Araponga, Fazenda Neblina. Floresta Estacional Semidecidual - Área um tanto perturbada, trilha da Ranunculaceae, 26.V.1995, Leoni, L.S. 2569 (SP); Araponga, Serra da Gama, estrada para Bom Jesus da Madeira, beira da estrada a mais ou menos $100 \mathrm{~m}$ da casa da sede da Fazenda da Neblina, 9.X.1986, Vieira, M.F. 476, et al. (VIC). Ferros, Lugar denominado que geme, 17.VIII.1950, Duarte, A.P. 3080 (RB). Fervedouro, Parque Estadual da Serra do Brigadeiro, 10.VII.1999, Lombardi, J.A. 3121 (BHCB). Ouro Preto, Estação Ecológica do Tipuí, 10.III.1992, Pedrali s.n. et al. (HXBH 10146). Piau, Fazenda do Serrote, 28.VI.1945, Heringer, E.P. 1937 (RB). Reduto, L.R. (Sítio do Sr. Paulo Heringer), 8.X.1944, Heringer, E.P. 1622 (RB). Sem município, Mexia, Y. 5148 (VIC). 


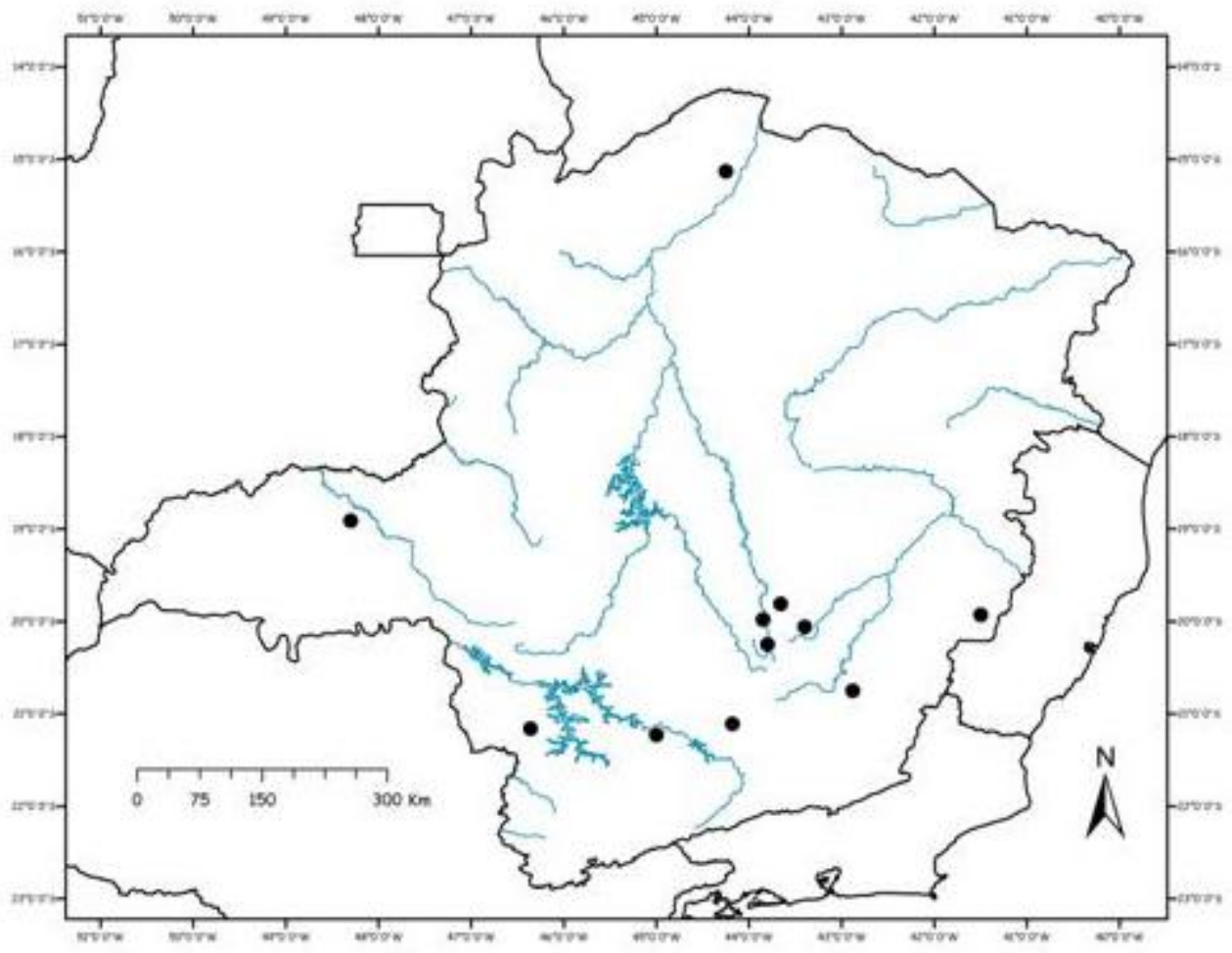

Figura 32: Mapa de distribuição geográfica de B. hirtel/o

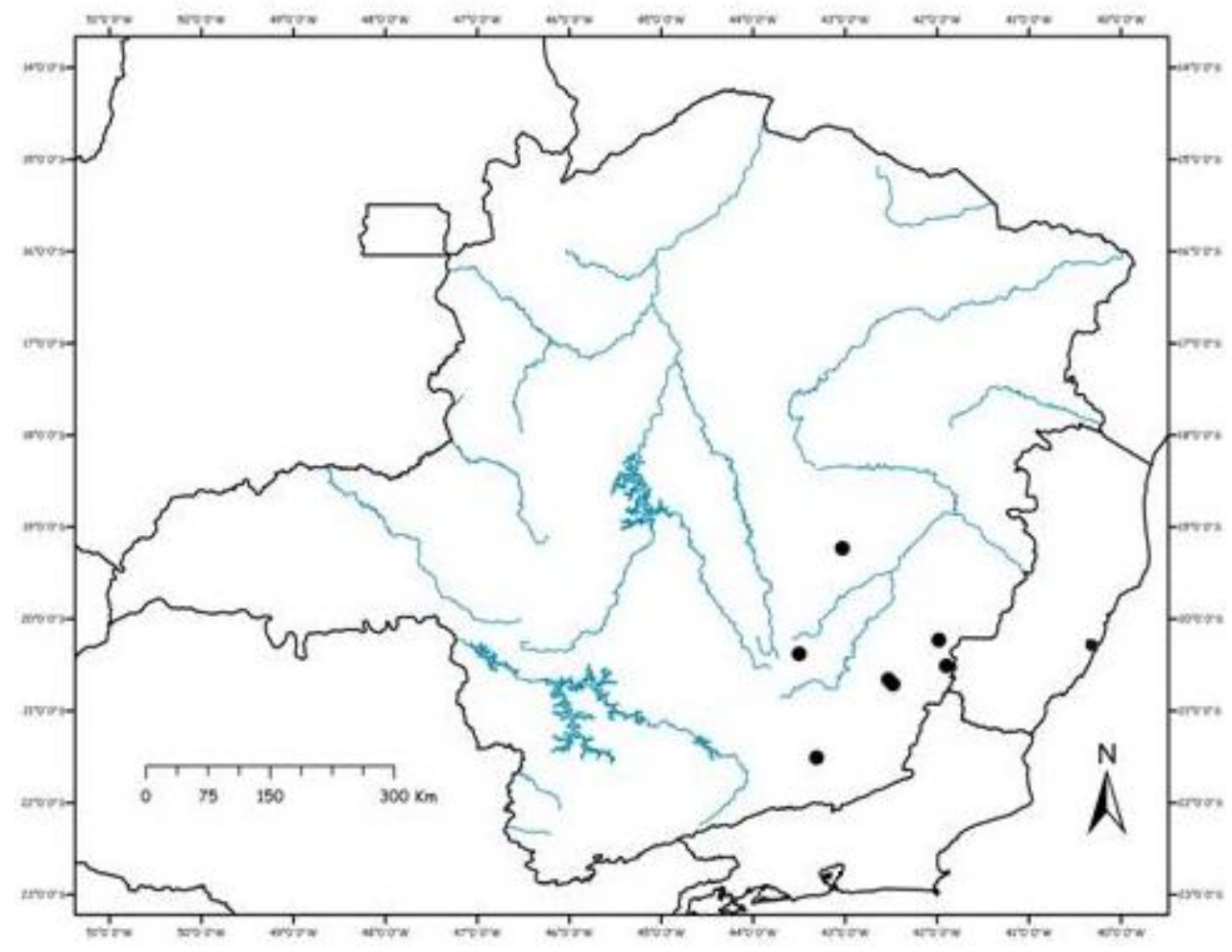

Figura 33: Mapa de distribuição geográfica de B. hugelii 


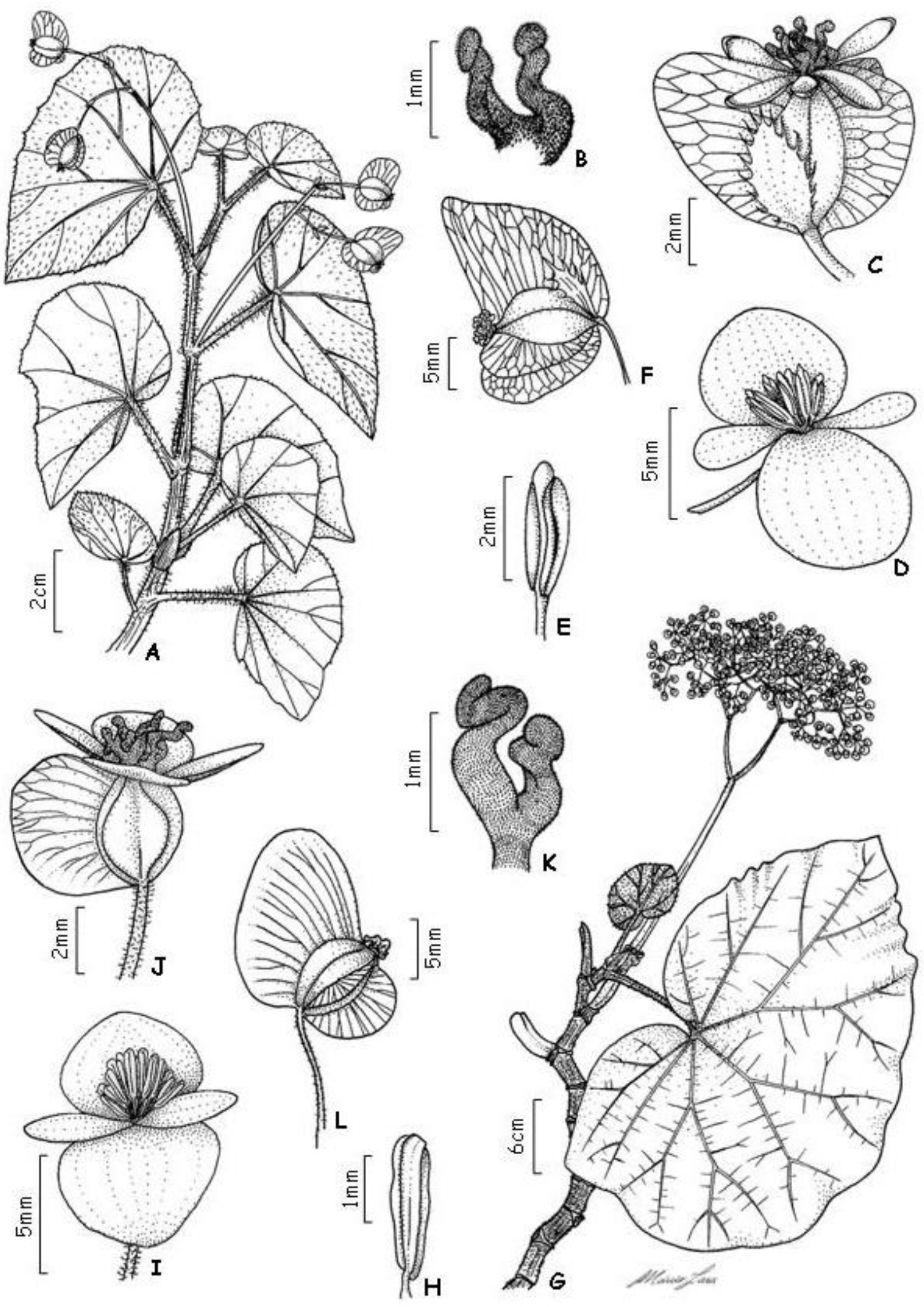

Figura 34: A-F: B. hirtella A- hábito; B- estigma; C- flor pistilada; D-flor estaminada; E- estame; F- cápsula. G-L: $\boldsymbol{B}$. hugelij G- hábito; H- estame; I- flor estaminada; J- flor pistilada; K- estigma; L- cápsula: [A:M. Brandão, 13073; B-F: R.C. Mota, 2648 (BHCB). G-I: L.S. Leoni, 2569 (SP); J-K: Y. Mexia, 5148 et al (VIC), L: M.F. Vieira, 476 (VIC)]. 
4.4.17. Begonia incisoserrata A. DC. in Martius, FI. bras., 4(1):374, 1861.

Scheidweileria incisoserrata Klotzsch, Abh. Königl. Akad. Wiss. Berlin 1854, :181, 1855.

Wageneria incisoserrata Klotzsch ex A. DC., in Martius, FI. bras., 4(1):374, 1861.

(PRANCHA: fig.37: A-F, pág.83; MAPA: fig.35, pág.82; FOTO: fig.30, pág.71)

ERVAS robustas, escabrosas, indumento formado por tricomas simples, curtos e por escamas, ambos duros, até $2,5 \mathrm{~m}$ alt. CAULES $2 \mathrm{~cm}$ diâm., eretos, suculentos, estriados, simples, verdes, glabrescentes; entrenós 4-4,5cm comp. ESTÍPULAS 2-3cm comp., 0,9$1,5 \mathrm{~cm}$ larg., ovais, ápice agudo, base truncada, margem levemente ondulada, cartáceas, caducas, apressas, com tricomas esparsos. FOLHAS com pecíolos $8-20 \mathrm{~cm}$ comp., estriados, glabrescentes; lâminas palmatissectas, segmentos $12-30 \mathrm{~cm}$ comp., 3,5-10,5cm larg., papiráceos, elípticos, fortemente assimétricos, ápices acuminados, bases agudas, margem dentado-serreada, não atingindo o ponto a partir de onde as nervuras irradiam, deixando uma parte das mesmas expostas, glabrescente, sendo o indumento mais concentrado sob as nervuras, principalmente na faca abaxial, verdes em ambas as faces, 6-9 segmentos peninérveos. CIMEIRAS ca. 500 flores, 6-8 nós; pedúnculos $11-30 \mathrm{~cm}$ comp., glabrescentes; brácteas 1 par, ca. 1,5mm comp., aprox., 0,5mm larg., triangulares, ápice agudo a acuminado, base truncada, margem serreada, ciliada, com tricomas esparsos no dorso. FLORES ESTAMINADAS tépalas 4, as externas ca. $2 \mathrm{~mm}$ comp., aprox. 1,5mm larg., largamente ovais, ápice arredondado, base truncada, margem inteira a levemente ondulada, com tricomas na base (dorso), as internas aprox., $2 \mathrm{~mm}$ comp., ca. $1,5 \mathrm{~mm}$ larg., largamente ovais, ápice arredondado, base truncada, margem inteira a levemente ondulada, glabras, alvas a esverdeadas; pedicelos 0,5-0,7cm comp., escabros; bractéolas 1-2 pares, inconspícuas, ca. $1 \mathrm{~mm}$ comp., aprox. 0,5mm larg., triangulares, ápice agudo a acuminado, base truncada, margem serreada, ciliada, caducas, com tricomas esparsos no dorso; estames 15-25, ca. $2 \mathrm{~mm}$ comp., filetes livres; anteras 0,5-1mm comp., oblongas. FLORES PISTILADAS tépalas 5, semelhantes entre si, ca. $3 \mathrm{~mm}$ comp., 1-2mm larg., ovais a elípticas, ápice agudo, base truncada, margem ondulada a serreada, com tricomas na base (dorso), alvas a esverdeadas; pedicelos 2-4mm comp., escabros; bractéolas 1-2 pares, inconspícuas, ca. $1 \mathrm{~mm}$ comp., aprox. 0,5mm larg., triangulares, ápice agudo a acuminado, base truncada, margem serreada, ciliada, caducas, com tricomas esparsos no dorso; estiletes aprox. 3mm comp.; estigmas ca. $2 \mathrm{~mm}$ comp., ramos cilíndricos e sinuosos, hipanto escabro. CÁPSULAS 0,5-0,8cm comp., 0,8-1,1cm larg., tépalas, estiletes e bractéolas caducos, região locular $0,2-0,3 \mathrm{~cm}$ diâm., placentas inteiras; alas semelhantes entre si, 0,2-0,4cm larg., ápice obtuso a arredondado. SEMENTES oblongas.

DISTRIBUIÇÃO E HÁBITATS: Begonia incisoserrata é uma erva semi-heliófila e ocorre no Sul de Minas Gerais, em áreas dominadas pela Mata Atlântica, habitando bordas de matas úmidas. 
FLORAÇÃO E FRUTIFICAÇÃO: floresce nos meses de fevereiro e março e frutifica no mês de março.

COMENTÁRIOS: Begonia incisoserrata apresenta características únicas entre as espécies do gênero Begonia de Minas Gerais o porte robusto, o indumento escabroso formado por tricomas e escamas, e as folhas palmatissectas com segmentos de base aguda e margem dentado-serreada. Dentre as espécies estudadas, Begonia digitata Raddi e Begonia luxurians Scheidw. são as que se assemelham à Begonia incisoserrata, diferenciando-se pelas características discutidas na tabela VII, pág.51.

Devido ao número reduzido de materiais analisados procedentes de Minas Gerais, acredita-se que Begonia incisoserrata esteja subamostrada na área de estudo.

MATERIAL EXAMINADO: BRASIL. MINAS GeRAIS. Caldas, 2.II.1983, Regnell, A. I-390(SP).

MATERIAL ADICIONAL EXAMINADO: BRASIL. RIO DE JANEIRO. Sem município, Divisa Rio de Janeiro - Minas Gerais, 26.III.2008, Delfini, C. 50, \& Paula-Souza, J. (ESA). 
4.4.18. Begonia integerrima Spreng., Neue Entdeck., 2:174, 1820.

Begonia populnea A. DC., Ann. Sci. Nat. Bot., IV, 11:128, 1859.

Begonia integerrima Spreng. var. cardioides Irmsch., Bot. Jahrb. Syst. 76(1): 71, 1953. Tipo: Brasil. São Paulo. Alto da Serra, Edwall s.n., VIII/1902 (Holótipo: SP 8741!).

(PRANCHA: fig.37: G-L, pág.83; MAPA: fig.36, pág.82)

ERVAS hemiepífitas, glabras, atingindo até $7 \mathrm{~m}$ alt. do solo. CAULES 0,2-0,5cm diâm., eretos a escandentes, suculentos, cilíndricos a estriados, ramificados, verdes, glabros; entrenós (0,8-)1,5-3(-3,5)cm comp. ESTÍPULAS 0,5-1,5cm comp., 0,3-0,7cm larg., ovais a triangulares, ápice mucronulado, base truncada, margem inteira, membranáceas, caducas a tardiamente caducas, apressas, glabras. FOLHAS com pecíolos 1,5-5,5cm comp., cilíndricos a estriados, glabros; lâminas (2,7-)3,4-6cm comp., (1,5-)2-4,5cm larg., inteiras basifixas, papiráceas, ovais a largamente ovais a cordiformes, simétricas a levemente assimétricas, ápice acuminado, base arredondada a cordada, margem inteira a levemente ondulada, glabras, face adaxial verde, face abaxial verde a avermelhada, venação actinódroma, 4-6 nervuras na base. CIMEIRAS 5-15 flores, 2-4 nós; pedúnculos 0,7-3cm comp., glabros; brácteas 1 par, 0,8-1,5cm comp., 0,3-0,7cm larg., ovais a lanceoladas, ápice mucronulado, base truncada, margem inteira, tardiamente caducas, glabras. FLORES ESTAMINADAS tépalas 4, as externas $0,7-1,1 \mathrm{~cm}$ comp., 0,5-1cm larg., ovais a largamente ovais, ápice obtuso a arredondado, base arredondada a cordada, margem inteira, glabras, as internas 0,6-1,1cm comp., 0,2-0,7cm larg., elípticas, ápice arredondado, base cuneada, margem inteira, glabras, alvas, alvas com base ou ápice róseo a vináceo, a vináceas; pedicelos 0,6-1,4cm comp., glabros; bractéolas 1-2 pares, 0,8-1,1cm comp., 0,5-0,8cm larg., ovais, ápice mucronulado, base truncada a arredondada, margem inteira, tardiamente caducas, glabras; estames 10-20, aprox. $4 \mathrm{~mm}$ comp., filetes unidos na base; anteras aprox. $3 \mathrm{~mm}$ comp., poricidas terminais, elípticas. FLORES PISTILADAS tépalas 5, semelhantes no tamanho e forma, 1-1,5cm comp., 0,3-1 cm larg., obovais, ápice arredondado a obtuso, base truncada, margem inteira, glabras, alvas a vináceas; pedicelos (0,6-)1-2cm comp., glabros; bractéolas 1-2 pares, 0,8-1,1cm comp., 0,5-0,8cm larg., ovais, ápice mucronulado, base truncada a arredondada, margem inteira, tardiamente caducas, inseridas no pedicelo; estiletes ca. $7 \mathrm{~mm}$ comp., estigmas ca. $3 \mathrm{~mm}$ comp., ramos cilíndricos e sinuosos, hipanto glabro. CÁPSULAS 0,5-1,5cm comp., 0,7$1,7 \mathrm{~cm}$ larg., estiletes persistentes, tépalas caducas, região locular 0,5-1,7cm diâm., placentas partidas; alas diferentes entre si, sendo a maior levemente ascendente; ala maior 0,5-0,7cm larg., ápice arredondado a obtuso; alas menores 0,2-0,4cm larg. SEMENTES fusiformes.

DISTRIBUIÇÃO E HÁBITATS: Begonia integerrima é encontrada na Zona da Mata mineira, nos domínios da Mata Atlântica, entre altitudes que variam de 800 a $1500 \mathrm{~m}$. Esta espécie cresce no solo, ascende nos troncos de árvores e, possivelmente, torna-se epífita atingindo até $7 \mathrm{~m}$ alt. do solo.

FLORAÇÃO E FRUTIFICAÇÃO: floresce e frutifica no mês de agosto. 
COMENTÁRIOS: Begonia integerrima é uma erva caracterizada pelo hábito trepadeiro ou hemiepífito, pelas lâminas ovais a largamente ovais a cordiformes, simétricas ou levemente assimétricas, pelas anteras poricidas terminais e pelas sementes fusiformes. Apresenta similaridades morfológicas com Begonia convolvulacea A. DC. e Begonia fruticosa $A$. DC., diferindo destas espécies pelas características discutidas na tabela IV, pág.37.

MATERIAL EXAMINADO: BRASIL. Minas GeraIs. Alto Caparaó, Parque Nacional do Caparaó. Vale Verde, 5.VIII.1996, Leoni, L.S. 3416 (ESA); Parque Nacional - Vale Verde. Cresce no interior da floresta estacional semidecidual submontana, 5.VIII.1996, Leoni, L.S. 3416 (HB); Araponga, Parque Estadual da Serra do Brigadeiro. Trilha do Mucuri. 1300-1325 m.s.m., 23.III.2008, Delfini, C. 38, \& Paula-Souza, J. (ESA); Serra da Araponga - Fazenda Neblina. Floresta Estacional Semidecidual. Cresce ao lado da estrada, próximo ao laboratório de campo, como epífita a poucos metros do solo, 9.VIII.1994, Leoni, L.S. 2633 (SP).

MATERIAL ADICIONAL EXAMINADO: BRASIL. SÃo PAULO. Município? Alto da Serra, mata virgem, Edwall, G., CGG5765 (SP). 


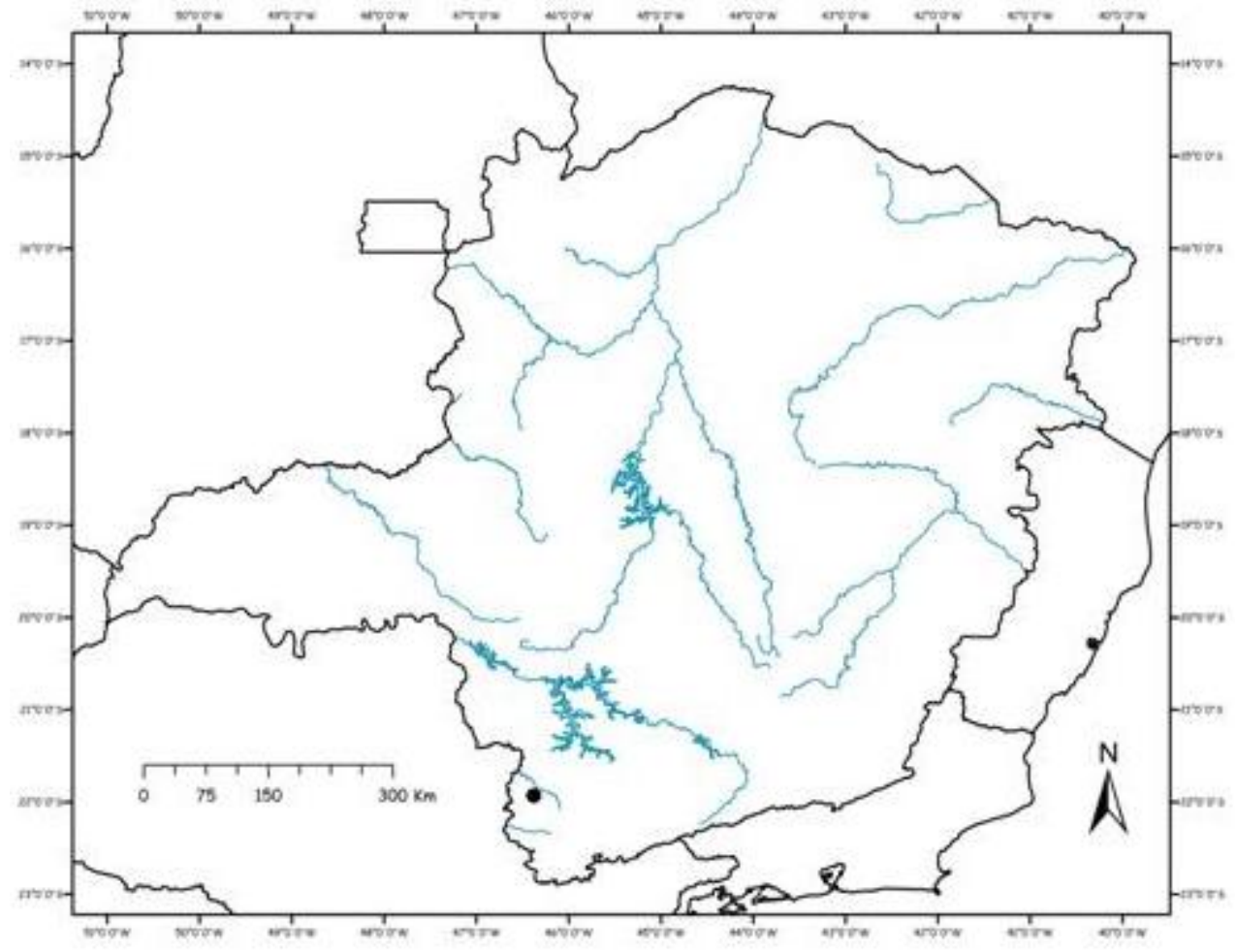

Figura 35: Mapa de distribuição geográfica de B incisoserroto

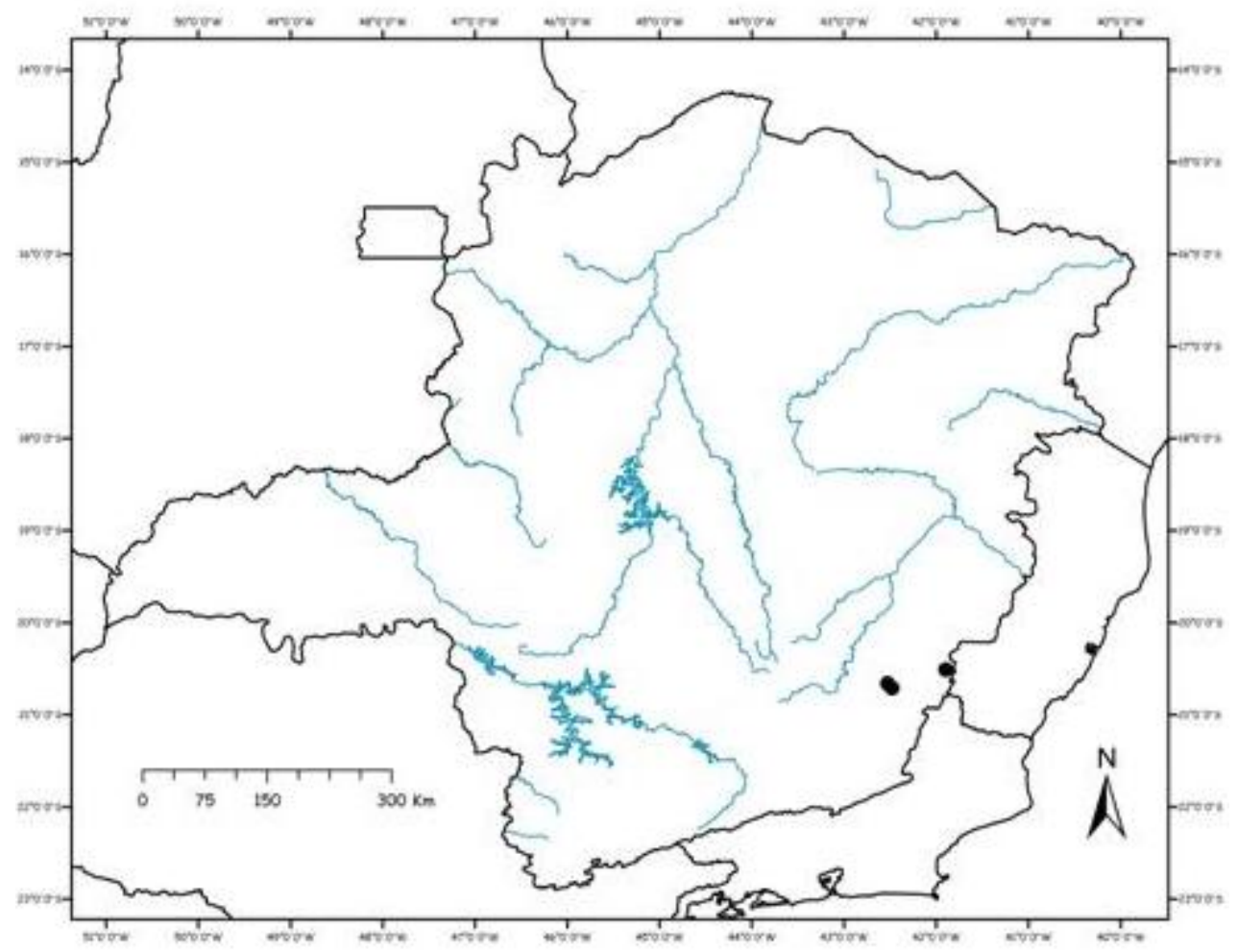

Figura 36: Mapa de distribuição geográfica de B. integerrima 


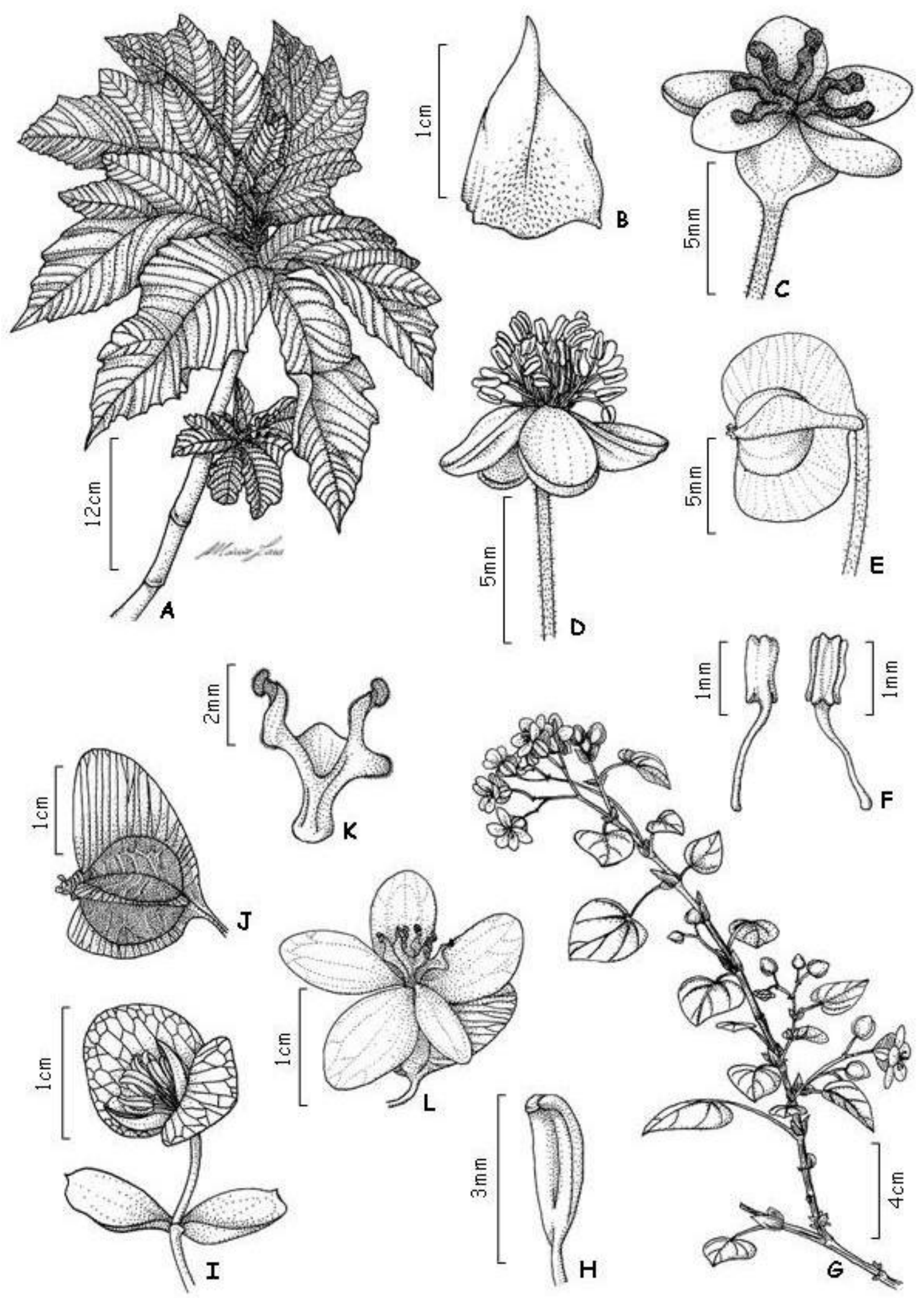

Figura 37: A-F: B. incisoserrata A- hábito; B- estípula; $C$ - flor pistilada; D- flor estaminada; E- cápsula; F- estame. G-L: $\boldsymbol{B}$. integerrina. G- hábito; H- estame; I- flor estaminada; J-cápsula; K- estigma: L- flor pistilada. [A-F: C. Delfini, 50 \& J. Paula-Souza (ESA). G-I: L.S. Leoni, 2633 (GFJP); J: L.S. Leoni, 3416 (GFJP); K-L: L.S. Leoni, 2633 (GFJP)]. 
4.4.19. Begonia Iuxurians Scheidw., Allg. Gartenzeitung, 16:131, 1848.

Scheidweileria luxurians (Scheidw.) Klotzsch, Monatsber Königl. Preuss. Akad. Wiss. Berlin, :123, 1854.

(PRANCHA: fig.40: A-E, pág.89; MaPA: fig.38, pág.88; Foto: fig.31: A-C, pág.71)

ERVAS robustas, lanuginosas, indumento ferrugíneo formado por tricomas longos e finos (simples ou dicotômicos), estes predominantes e por tricomas estrelados esparsos, até $3 \mathrm{~m}$ alt. CAULES 0,8-2cm diâm., eretos, estriados, simples, verdes a avermelhados, glabrescentes, tricomas ferrugíneos; entrenós 2-6cm comp. ESTÍPULAS 0,6-1,5cm comp., 0,3-0,7cm larg., triangulares, ápice mucronulado, base truncada, margem inteira a irregularmente ondulada, papiráceas, tardiamente caducas, apressas, lanuginosas. FOLHAS com pecíolos (6,5-)7-11cm comp., estriados, glabrescentes; lâminas palmatissectas, segmentos (13-)16-32,6cm comp., (2-)3-4,5cm larg., papiráceos, elípticos, simétricos a levemente assimétricos, ápices acuminados, raramente agudos, bases atenuadas, margem serreada a serrilhada, atingindo o ponto a partir de onde irradiam as nervuras, não deixando as mesmas expostas, glabrescentes, sendo o indumento distribuído mais concentradamente na face abaxial das folhas, face adaxial verde, face abaxial verde a avermelhada, 9-15 segmentos peninérveos. CIMEIRAS ca. 500 flores, 7-8 nós; pedúnculos (8,5-)15-40cm comp., glabrescentes; brácteas 1 par, ca. $1 \mathrm{~cm}$ comp., aprox. 0,4cm larg., triangulares, ápice acuminado, base truncada, margem irregularmente ondulada, caducas, lanosas. FLORES ESTAMINADAS tépalas 4 , as externas ca. $4 \mathrm{~mm}$ comp., aprox. $3 \mathrm{~mm}$ larg., largamente ovais, ápice arredondado, base arredondada, margem inteira, glabras ou com tricomas esparsos, as internas ca. $4 \mathrm{~mm}$ comp., 2-3mm larg., ovais, ápice arredondado a obtuso, base atenuada, margem inteira, glabras, alvas a esverdeadas; pedicelos 6-7mm comp., glabrescentes; bractéolas 1-2 pares, ca. $6 \mathrm{~mm}$ comp., 1-2 $\mathrm{mm}$ larg., triangulares, ápice mucronulado, margem irregularmente ondulada, caducas, lanuginosas; estames 15-25, ca. 3mm comp., filetes livres; anteras ca. $1 \mathrm{~mm}$ comp., rimosas, oblongas. FLORES PISTILADAS tépalas 5 , semelhantes entre si, 3-4mm comp., ca. $2 \mathrm{~mm}$ larg., elípticas, ápice agudo, base atenuada, margem ondulada, glabrescentes, alvas a esverdeadas; pedicelos $5-6 \mathrm{~mm}$ comp., glabrescentes; bractéolas 1-2 pares, ca. $6 \mathrm{~mm}$ comp., 1-2mm larg., triangulares, ápice mucronulado, base truncada, margem irregularmente ondulada, inseridas diretamente no pedicelo, caducas, lanuginosas; estiletes ca. $2 \mathrm{~mm}$ comp.; estigmas aprox. $1 \mathrm{~mm}$ comp., ramos cilíndricos e espiralados, hipanto glabrescente. CAPSULAS ca. $5 \mathrm{~mm}$ comp., $5-7 \mathrm{~mm}$ larg., estiletes persistentes, tépalas e bractéolas caducos, região locular ca. $4 \mathrm{~mm}$ diâm., placentas inteiras, alas semelhantes entre si, 3-5mm larg., ápice arredondado. SEMENTES oblongas.

DISTRIBUIÇÃO E HÁBITATS: Begonia luxurians é uma erva semi-heliófila que ocorre nas regiões Central, Sul e Zona da Mata mineira, nos domínios da Mata Atlântica, habitando locais temporariamente alagados, úmidos e/ou sombrios, grotas, locais iluminados como barrancos e bordas de matas. 
FLORAÇÃO E FRUTIFICAÇÃO: floresce de março a maio e de setembro a novembro e frutifica de fevereiro a março e de setembro a novembro.

COMENTÁRIOS: Begonia luxurians apresenta como características únicas entre as espécies de Begonia de Minas Gerais, as folhas palmatissectas e o indumento lanuginoso formado por tricomas longos e finos (simples ou dicotômicos), estes predominantes e por tricomas estrelados esparsos. As inflorescências plurifloras são bastante perfumadas e visitadas por abelhas.

São reconhecidas duas variedades para Begonia luxurians. B. luxurians var. luxurians e B. luxurians var. sampaiona Brade. De acordo com a descrição original, $B$. luxurians var. sampaioana difere de B. luxurians var. luxurians pelas maiores dimensões dos segmentos foliares e, embora ocorra uma pequena sobreposição $B$. luxurians var. sampaioana possui distribuição restrita ao Estado de Minas Gerais. Entretanto, nos materiais analisados observou-se que as dimensões dos segmentos foliares podem ser bastante variáveis e muito discrepantes, portanto, há uma grande dificuldade (ou mesmo impossibilidade) em se identificar materiais de Begonia luxurians ao nível de variedade e, como não foram analisados os tipos dos nomes em questão, nem os demais materiais dos outros locais de distribuição do táxon, não foi possivel estabelecer um padrão dentro de toda a variabilidade morfológica de Begonia luxurians que permita sua correta identificação neste nível.

Begonia luxurians apresenta similaridades morfológicas com Begonia digitata Raddi e Begonia incisoserrata A. DC., sendo as diferenças entre estas espécies discutidas anteriormente na tabela VII, pág.51.

Material examinado: BRASIL. Minas Gerais. Araponga, Parque Estadual da Serra do Brigadeiro. Trilha do Mucuri. 1300-1325 m.s.m., 23.III.2008, Delfini, C. 45, \& Paula-Souza, J. (ESA); Fazenda Neblina - Floresta Estacional Semidecidual - Área um tanto perturbada, 19.V.1991, Leoni, L.S. 1572 (SP); Serra do Brigadeiro, 4.IV.1992, Meira Neto, J.A.A. 904, et al. (VIC); Serra da Gama, estrada para Bom Jesus da Madeira, beira da estrada a mais ou menos $100 \mathrm{~m}$ da casa da sede da Fazenda da Neblina, 9.X.1986, Vieira, M.F. 478, et al. (VIC). Caeté, 29.VII.1993, Bastos, E. 660 (PAMG). Estouro, Morro do Brigadeiro, próximo a fazenda, 13.II.1985, Vidal, W.N. 592, et al. (VIC). Ferros, Entre Ferros e Viamão, Zona da Mata, 17.IX.1950, Duarte, A.P. 3081 (RB). Fervedouro, Parque Nacional da Serra do Brigadeiro, 10.VII.1999, Lombardi, J.A. 3077 (BHCB). Juiz de Fora, Fazenda do Sertão, rodovia Coronel Pacheco - Juiz de Fora, 13.X.1945, Heringer, E.P. s.n. (VIC 12751); Morro do Redentor, III.1993, Lisboa, M.L.G s.n., et al. (VIC 14429). Lima Duarte, Parque Estadual do Ibitipoca. Mata pluvial montana, 19.XI.1986, Andrade, P.M. 831, et al. (SP); Parque Estadual da Serra do Ibitipoca, Mata Grande, 10.III.2004, Forzza, R.C. 3151, et al. (RB); Serra do Ibitipoca - Mata do Açude, 18.IX.1940, Magalhães, M. 395, (BHCB); Serra de Ibitipoca, mata do açude, margem de córego, 18.IX.1940, Magalhães, M. 395 (RB). Piau, Fazenda do Serrote, 26.VI.1945, Heringer, E.P. s.n. (VIC 12995). Santa Rita de Jacutinga, Serra do Pacau, 29.IX.1989, Grandi, T.S.M. 2617, et al. (SP). Viçosa, Fazenda Crissiuma, 26.II.1935, Kuhlmann s.n. (VIC 2434); Fazenda de Crissiúma. Escola - Viçosa, 26.XI.1931, Kuhlmann, J.G. s.n. (RB 136901). Sem município, Fazenda Estouro, 2.XI.1941, Alvim, P. s.n. (VIC 3442); Saint-Hilaire, A. 100 (HB). 
4.4.20. Begonia maculata Raddi, Mem. Mat. Fis. Soc. Ital. Sci., Modena, 18:406, 1820

Begonia argyrostigma Fischer ex Link \& Otto, Icon. PI. Sel., 23, pl. 10, 1821.

Begonia punctata hort. ex Steudel, Nom. Veg. ed. 2,1:194, 1840.

Gaerdtia maculata (Raddi) Klotzsch, Monatsber. Königl. Preuss. Akad. Wiss. Berlin, :123, 1854.

(PRANCHA: fig.40: F-I, pág.89; MAPA: fig.39, pág.88)

ERVAS robustas, glabras, 1-3m alt. CAULES (0,3-)0,5-1cm diâm., eretos, subcarnosos, cilíndricos, estriados, ramificados, verdes a marrons, glabros; entrenós (0,8-)1-2cm comp., ESTÍPULAS 2-3cm comp., 0,5-1,5cm larg., ovais, ápice acuminado, base truncada, margem inteira, membranáceas, caducas, apressas, glabras. FOLHAS com pecíolos 1,5$3 \mathrm{~cm}$ comp., cilíndricos, estriados, glabros; lâminas 10-15cm comp., 3,5-5cm larg., inteiras, basifixas, cartáceas, oblíquas a transversais, elípticas, assimétricas, ápice agudo a acuminado, base cordada, margem inteira, glabras em ambas as faces, face adaxial verde (in vivo verde com manchas cinzas), faca abaxial avermelhada, venação actinódroma, 5-8 nervuras na base. CIMEIRAS 40-50 flores, 4-6 nós; pedúnculos 4,5-6cm comp., glabros; brácteas 1 par, comp., larg., forma, ápice, base e margem não vistos, caducas, indumento não visto. FLORES ESTAMINADAS tépalas 4, as externas $1,5-1,8 \mathrm{~cm}$ comp., ca. $1,5 \mathrm{~cm}$ larg., ovais, ápice obtuso a arredondado, base arredondada, margem inteira, glabras, as internas 6-8mm comp., 2-3mm larg., elípticas, ápice obtuso a arredondado, base aguda, margem inteira, glabras, róseas a avermelhadas; pedicelos 5-8mm comp., glabros; bractéolas 2-4 pares, ca. $5 \mathrm{~mm}$ comp., aprox. $2 \mathrm{~mm}$ larg., elípticas a largamente ovais, base truncada, margem inteira, caducas, glabras; estames 20-25, ca. $3 \mathrm{~mm}$ comp., filetes livres; anteras 1-1,5cm comp., rimosas, extrorsas, obovais. FLORES PISTILADAS não vistas. CÁPSULAS cordiformes, $2-3 \mathrm{~cm}$ comp., tépalas, estiletes e bractéolas caducos, região locular 5-7mm diâm., placentas partidas; alas semelhantes entre si, 0,5-1cm larg., ápice arredondado. SEMENTES oblongas.

DISTRIBUIÇÃO E HÁBITATS: Begonia maculata é uma planta heliófila ou umbrófila, encontrada na Zona da Mata e na região Central de Minas Gerais, em áreas dominadas por Mata Atlântica e Cerrado. Segundo Araújo \& Costa (1972), Begonia maculata cresce em solos humosos, humoso-arenosos ou humoso-argilosos.

FLORAÇÃO E FRUTIFICAÇÃO: floresce no mês de novembro e frutifica em setembro e outubro.

COMENTÁRIOS: Begonia maculata é caracterizada pelo porte robusto, pelas folhas transversais elípticas, pelas manchas alvas na face adaxial in vivo e pelas cápsulas cordiformes com alas desenvolvidas semelhantes entre si. Esta espécie é bastante cultivada em jardins residenciais e, talvez, os materiais coletados em Minas Gerais sejam procedentes de cultivo.

Baseado somente em características que variam de acordo com o meio, foram propostas quatro variedades para Begonia maculata: B. maculata var. maculata, B. 
maculata var. argentea (Van Houtte) A. DC., B. maculata var. elegantissima hort. ex. Fotsch e B. maculata var. wightii hort. ex. Fotsch, que foram reconhecidas por Smith et al. (1986) e Golding \& Wasshausen (2002). Entretanto, Araújo \& Costa (1972) indicaram que a espécie apresenta uma grande plasticidade $e$, possivelmente isto explique 0 sucesso obtido no cultivo em jardins e, portanto, Jacques (2002) não reconheceu categorias infra-específicas para Begonia maculata. Nos poucos materiais analisados de Minas Gerais também não foi possível a identificação das mesmas e, como não foram analisados os tipos dos nomes em questão, nem os demais materiais dos outros locais de distribuição da espécie, não foi possivel estabelecer um padrão dentro de toda a variabilidade morfológica que permita sua correta identificação neste nível.

Begonia maculata apresenta similaridades morfológicas a Begonia angularis Raddi e estas espécies podem ser prontamente diferenciadas pelo fato desta última apresentar caules e pecíolos angulosos, placentas inteiras e cápsulas com alas desenvolvidas diferentes entre si, sendo a ala maior ligeiramente ascendente. Além disso, as estípulas são persistentes, triangulares e reflexas, contrapondo com estípulas caducas, ovais e apressas em Begonia maculata.

MATERIAL EXAMINADO: BRASIL. MINAS GeraIs. Belo Horizonte, Cultivada, X.1979, Grandi, T.S.M. 103, (SP). Coronel Pacheco, Fazenda Santa Cecília. Planta cultivada não sabendo se foi encontrada em matas da região, 15.IX.1944, Heringer, E.P. 1566 (RB); Coronel Pacheco, Fazenda Santa Cecília, 15.IX.1994, Heringer, E.P. 1566 (VIC). Ouro Preto, 24.XI.1980, Ferrari, J.M. 633 $(B H C B, S P)$. 


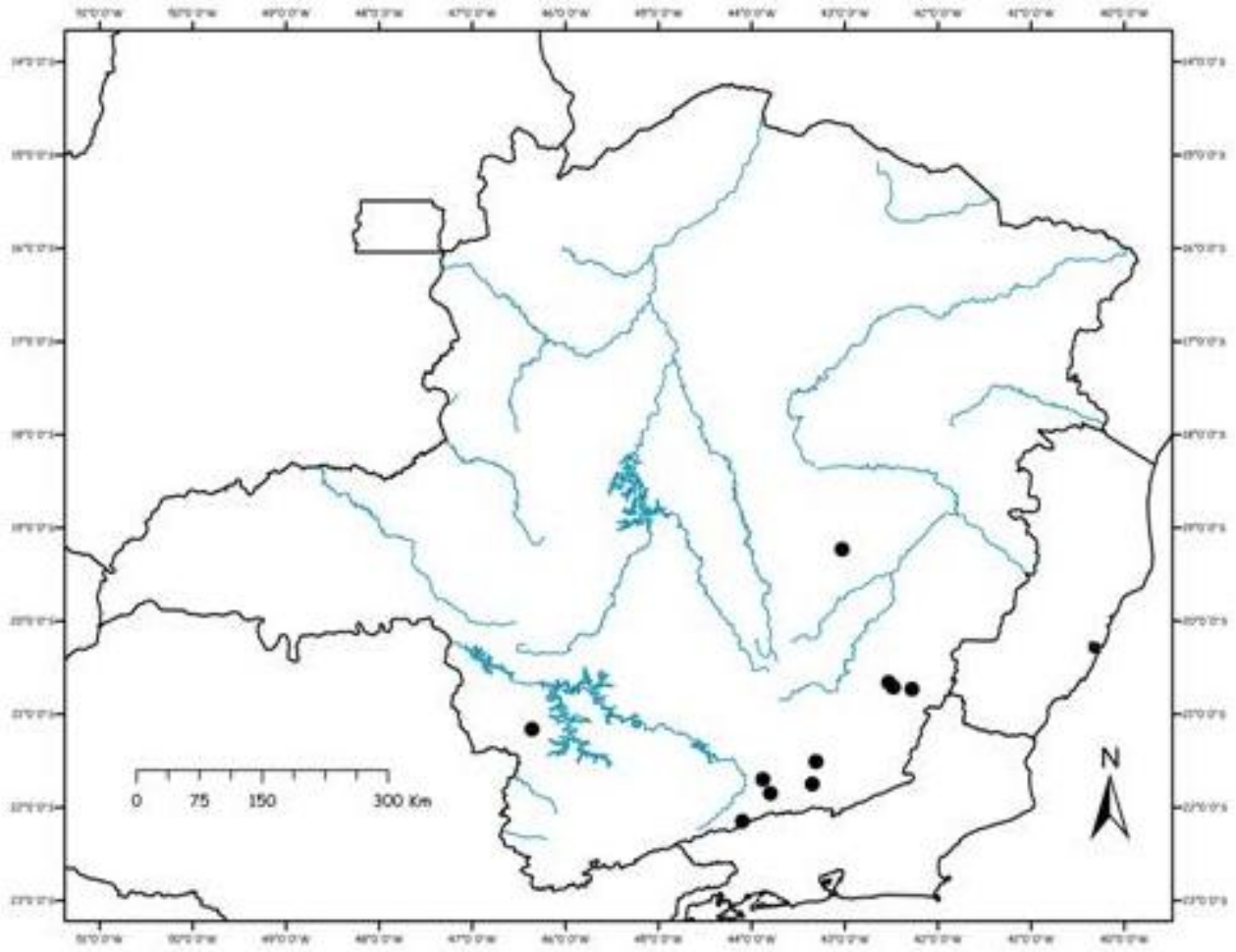

Figura 38: Mapa de distribuição geográfica de $B$. Kuxurions

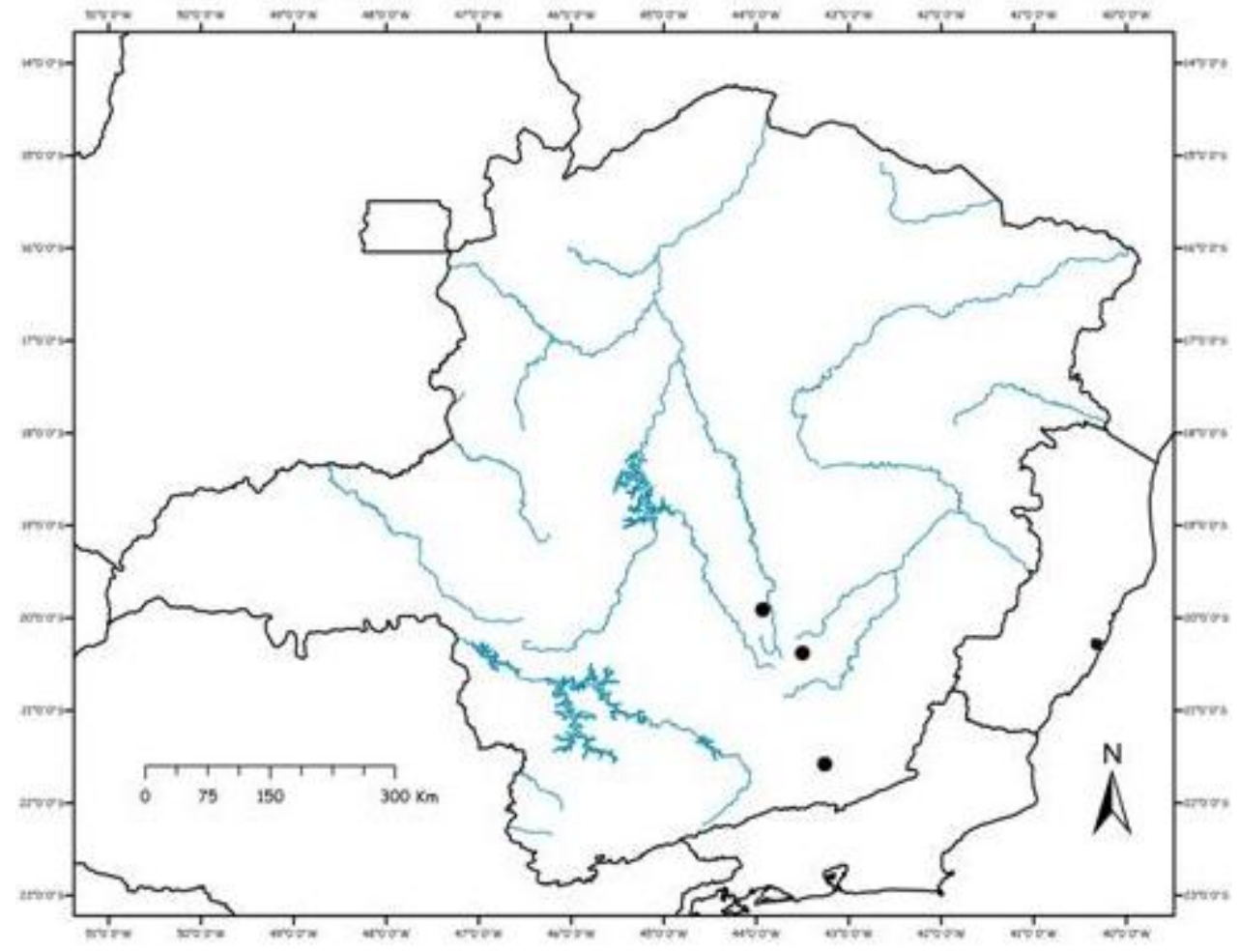

Figura 39: Mapa de distribuição geográfica de B. moculoto 

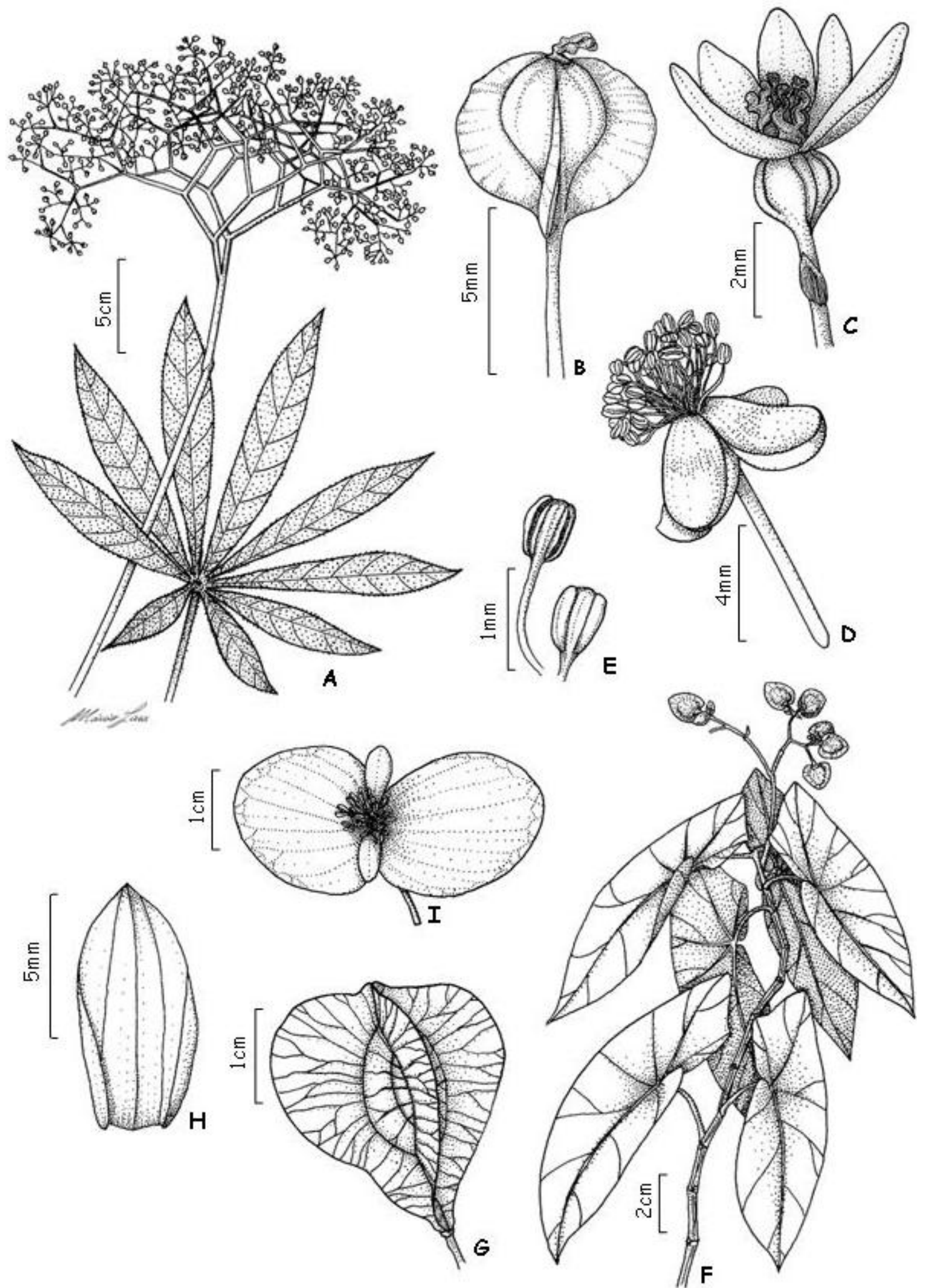

Figura 40: A-E: B. Mxurians A- hábito; B- cápsula; $C$ - flor pistilada; D- flor estaminada; E- estame. F-I: $\boldsymbol{B}$. maculata. F- hábito; G- cápsula; H- bractéola; I- flor estaminada; Jestípula. [A-E: C. Delfini, 45 \& J. Paula-Souza (ESA). F: J.M. Ferrari, 633 (BHCB); G: E.P. Heringer, 1566 (VIC): H-I: J.M. Ferrari, s.n. (BHCB 2315)]. 
4.4.21. Begonia moysesii Brade, Arq. Bot. Estado São Paulo, n.s., 3:209, pl. 52 , 1958. Tipo: Brasil. Município de Delfim Moreira, São Francisco dos Campos, beira da rodovia para Itajubá, Kuhlmann, 2401, VI/1950 (Holótipo: SP!).

(PRANCHA: fig.43: A-F, pág.95; MAPA: fig.41, pág.94)

ERVAS, indumento aracnóide, tricomas simples finos e longos e tricomas glandulares nos pedicelos, às vezes nas tépalas, ca. $30 \mathrm{~cm}$ alt. CAULES ca. $7 \mathrm{~mm}$ diâm., decumbentes, suculentos, estriados, pouco ramificados, marrons, aracnóides; entrenós ca. $1 \mathrm{~cm}$ comp. ESTÍPULAS aprox. $1,5 \mathrm{~cm}$ comp., 0,6 cm larg., ovais, ápice mucronado a aristado, base truncada, margem irregularmente ondulada, membranáceas, persistentes, apressas, aracnóides. FOLHAS com pecíolos 20-25cm comp., angulosos quando jovens, estriados, glabrescentes; lâminas ca. $22 \mathrm{~cm}$ comp., aprox. $11,5 \mathrm{~cm}$ larg., inteiras, basifixas, membranáceas, oblíquas a transversais, elípticas a ovais, assimétricas, ápice acuminado, base lobada, margem irregularmente ondulada, glabras em ambas as faces, verdes em ambas as faces, venação actinódroma, 4-5 nervuras na base. CIMEIRAS 5-10 flores, 3-4 nós; pedúnculo 9-24,5cm comp., glabrescentes; brácteas 1 par, comp., larg., forma, ápice, base, margem não vistos, caducas, indumento não visto. FLORES ESTAMINADAS tépalas 4 , as externas ca. $1 \mathrm{~cm}$ comp., aprox. $1 \mathrm{~cm}$ larg., obovais, ápice obtuso a arredondado, base arredondada, margem levemente ondulada, glabras, na internas ca. $1 \mathrm{~cm}$ comp., aprox. 0,9cm larg., obovais, ápice obtuso, base aguda, margem levemente ondulada, glabras, alvas; pedicelos ca. 0,5cm comp., glabrescentes, tricomas glandulares; bractéolas 1-3 pares, 8-9mm comp., 3-4mm larg., elípticas, ápice mucronulado, base truncada, margem irregularmente ondulada, persistentes, glabrescentes; estames 2540 , ca. $4 \mathrm{~mm}$ comp., filetes livres; anteras aprox. $2 \mathrm{~mm}$ comp., rimosas, oblongas. FLORES PISTILADAS (jovens) tépalas 5 , semelhantes entre si, ca. $4 \mathrm{~mm}$ comp., aprox. $3 \mathrm{~mm}$ larg., ovais a elípticas, ápice obtuso, base truncada, margem ondulada, glabrescentes, tricomas glandulares, alvas; pedicelos ca. $1 \mathrm{~cm}$ comp., glabrescente; bractéolas 1-3 pares, 8-9mm comp., 3-4mm larg., elípticas, ápice mucronulado, base truncada, margem irregularmente ondulada, inseridas nos nós das cimeiras, persistentes, glabrescentes; estiletes ca. $2 \mathrm{~mm}$ comp.; estigmas aprox. $1 \mathrm{~mm}$ comp., ramos cilíndricos e espiralados, hipanto aracnóide. CÁPUSULAS 1,4-1,7cm comp., 2,4-3cm comp., estiletes persistentes, tépalas e bractéolas caducos, região locular ca. $5 \mathrm{~mm}$ diâm., placentas inteiras, alas diferentes entre si, sendo a maior levemente ascendente; ala maior 1,5-2cm larg., ápice obtuso a arredondado; alas menores 3-4mm larg. SEMENTES oblongas a elípticas.

DISTRIBUIÇÃo E HÁBITATS: Begonia moysesii é uma espécie endêmica do Estado de Minas Gerais, encontrada na região Sul de Minas Gerais, nos domínios da Mata Atlântica, habitando orlas de matas.

FLORAÇÃO E FRUTIFICAÇÃo: floresce e frutifica no mês de junho.

COMENTÁRIOS: Begonia moysesii é uma erva caracterizada pelo indumento aracnóide, formado por tricomas simples finos e longos e por tricomas glandulares, pelas folhas transversais, elípticas a ovais e pelos pecíolos angulosos quando jovens. 
De acordo com a descrição original, Begonia moysesii compartilha o aspecto bulado das folhas na face adaxial (in vivo) com Begonia gehrtii Irmsch., sendo prontamente diferenciadas pelo fato desta última espécie apresentar indumento formado por escamas lanceoladas recurvadas e pelos pecíolos cilíndricos. Smith et al. (1986) e Golding \& Wasshausen (2002) separam estas duas espécies pelo revestimento dos pecíolos: glabros ou glabrescentes em Begonia gehrtii, contrapondo por pecíolos revestidos em Begonia moysesii.

Begonia moysesii também apresenta similaridades morfológicas com Begonia paulensis $A$. DC., entretanto estas espécies podem ser prontamente diferenciadas pelas características apresentadas na tabela $X$, pág. 99 .

Begonia moysesii é uma espécie conhecida somente através da coleção-tipo, portanto, como não há registros de novas coletas nos últimos 30 anos, de acordo com os critérios estabelecidos pela IUCN (2001), Begonia moysesii é classificada como uma espécie provavelmente extinta.

MATERIAL EXAMINADO: BRASIL. MINAS GeRAIS. Delfim Moreira, São Francisco dos Campos, beira da rodovia para Itajubá, 6.VI.1950, Kuhlmann, M. 2401 (SP). 
4.4.22. Begonia neocomensium A. DC., Ann. Sci. Nat. Bot., IV, 11:138, 1859.

(PRANCHA: fig.43: G-L, pág.95; MAPA: fig.42, pág.94)

SUBARBUSTOS, laxamente pustulosos, indumento formado por pequenas escamas, às vezes, achatadas e por tricomas simples mais tricomas estrelados, estes muito esparsos. CAULES 0,3-0,5cm diâm., eretos, subcarnosos, estriados, pouco ramificados, marrons, glabrescentes; entrenós $3-3,5 \mathrm{~cm}$. ESTÍPULAS não vistas, comp. e larg. não vistos, [ovais-oblongas, ápice acuminado, base truncada], margem não vista, caducas, [pilosas no dorso]. FOLHAS com pecíolos 10-13cm comp., cilíndricos, estriados, glabrescentes; lâminas 30-32,5cm comp., $17-18 \mathrm{~cm}$ larg., inteiras a levemente lobadas, basifixas, membranáceas, reniformes, assimétricas, ápice acuminado, base cordada, margem irregularmente crenulada, esparsamente ciliada, glabriúsculas em ambas as faces, indumento formado por pequenas escamas mais tricomas simples e tricomas estrelados, verdes em ambas as faces, venação actinódroma, 5-6 nervuras na base. CIMEIRAS 1030 flores, 3-4 nós; pedúnculos danificados; brácteas não vistas, comp. e larg. não vistos, [ovais a lanceoladas], ápice, base e margem não vistos, caducas, indumento não visto. FLORES ESTAMINADAS tépalas 4, as externas $5-6 \mathrm{~mm}$ comp., ca. $4 \mathrm{~mm}$ larg., ovais a largamente ovais, ápice arredondado, base arredondada, margem levemente ondulada, com escamas no dorso, as internas 3-4mm comp., 1-2mm larg., elípticas, ápice obtuso a arredondado, base aguda, margem levemente ondulada, glabras ou com glândulas translúcidas no dorso, alvas a róseas; pedicelos aprox. $5 \mathrm{~mm}$ comp., tricomas simples e escamas; bractéolas 1-4 pares, ca. $2 \mathrm{~mm}$ comp., 0,5-1 $\mathrm{mm}$ larg., triangulares a lanceoladas, ápice agudo a acuminado, base truncada, margem inteira, tardiamente caducas, carinadas, carinas com escamas mais glândulas translúcidas na metade superior; estames 15-20, ca. 3,5mm comp.; anteras ca. $1,5 \mathrm{~mm}$ comp., rimosas, oblongas. FLORES PISTILADAS jovens, tépalas 5, semelhantes entre si, ca. $3 \mathrm{~mm}$ comp., 2-2,5mm larg., elípticas a obovais, ápice arredondado a obtuso, base truncada, margem levemente ondulada, serreada a crenulada na metade superior, escamas esparsas, alvas a róseas; pedicelos ca, $5 \mathrm{~mm}$ comp., tricomas simples e escamas; bractéolas 1-4 pares, aprox. $2 \mathrm{~mm}$ comp., 0,5-1mm larg., triangulares a lanceoladas, ápice agudo a acuminado, base truncada, margem inteira, inseridas nos nós das cimeiras, tardiamente caducas, carinadas, carinas com escamas e glândulas translúcidas na metade superior; estiletes 1,5-2mm comp.; estigmas aprox. $1 \mathrm{~mm}$ comp., ramos cilíndricos e espiralados, hipanto revestido por tricomas simples e escamas. CÁPSULAS não vistas, placentas inteiras. SEMENTES não vistas.

DISTRIBUIÇÃO E HÁBITATS: Begonia neocomensium ocorre na Zona da Mata mineira, nos domínios da Mata Atlântica, em solo arenoso com deposição de matéria orgânica.

FLORAÇÃO E FRUTIFICAÇÃo: floresce no mês de setembro.

COMENTÁRIOS: Begonia neocomensium é um subarbusto caracterizado pelo indumento laxamente pustuloso formado por pequenas escamas (às vezes achatadas) e pelo indumento formado por tricomas simples e por tricomas estrelados, muito esparsos. 
O único espécime analisado de Begonia neocomensium para o Estado de Minas Gerais consta somente de duas folhas e algumas flores estaminadas e flores pistiladas jovens. Por conseguinte, para a elaboração da descrição foi necessária a utilização de informações complementares extraídas da obra princeps desta espécie.

Até o presente momento, só havia registros de coleta de Begonia neocomensium para o Estado da Bahia, portanto, verifica-se aqui um novo registro de Begonia para a flora de Minas Gerais.

MATERIAL EXAMINADO: BRASIL. Minas GeraIs. Ewbank da Câmara, Fazenda Cascatinha. Mata antropizada, solo arenoso com deposição de matéria orgânica, 13.IX.1994, Santos, H.G.P. 312 , et al. (SP). 


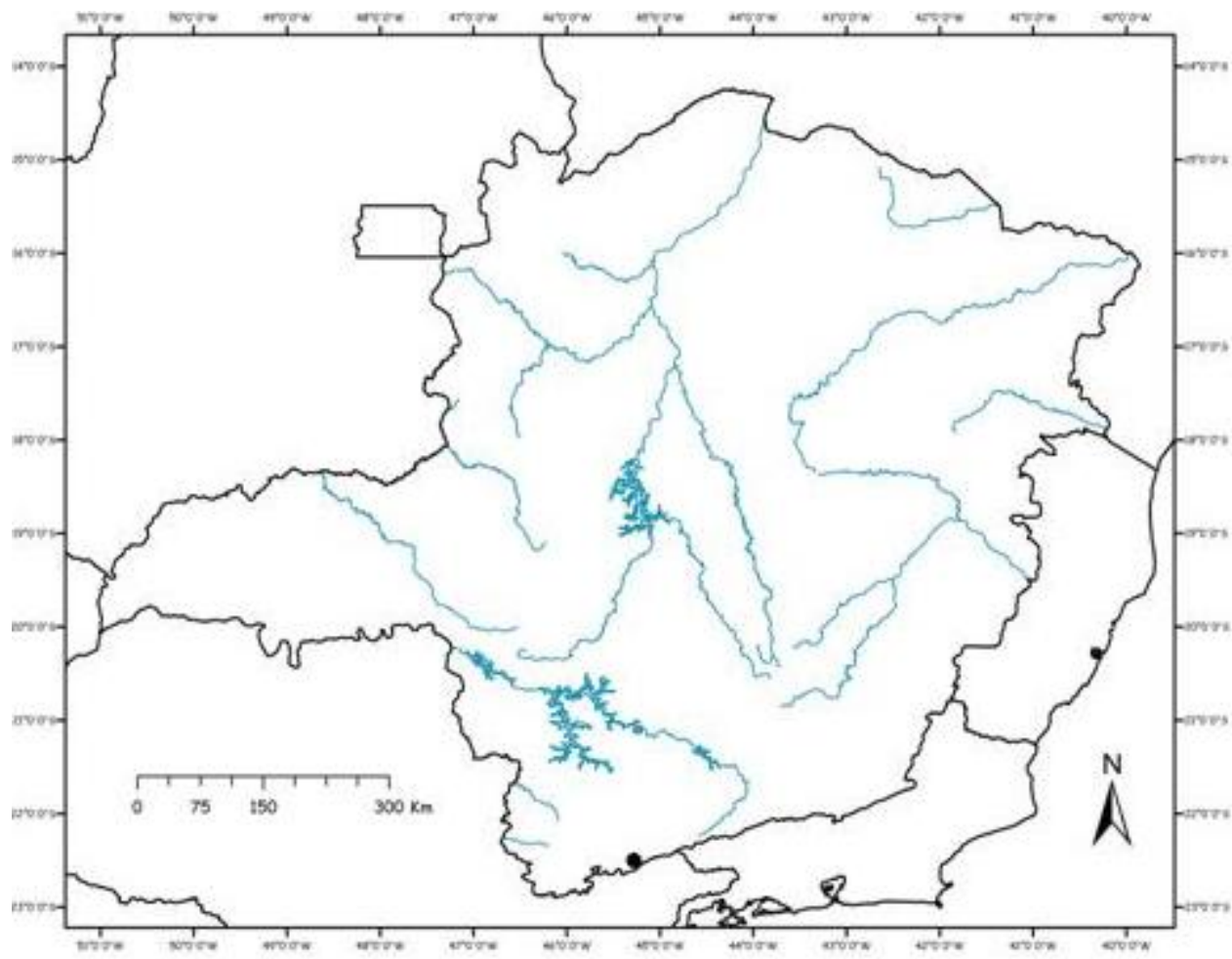

Figura 41: Mapa de distribuição geográfica de B. moysesii

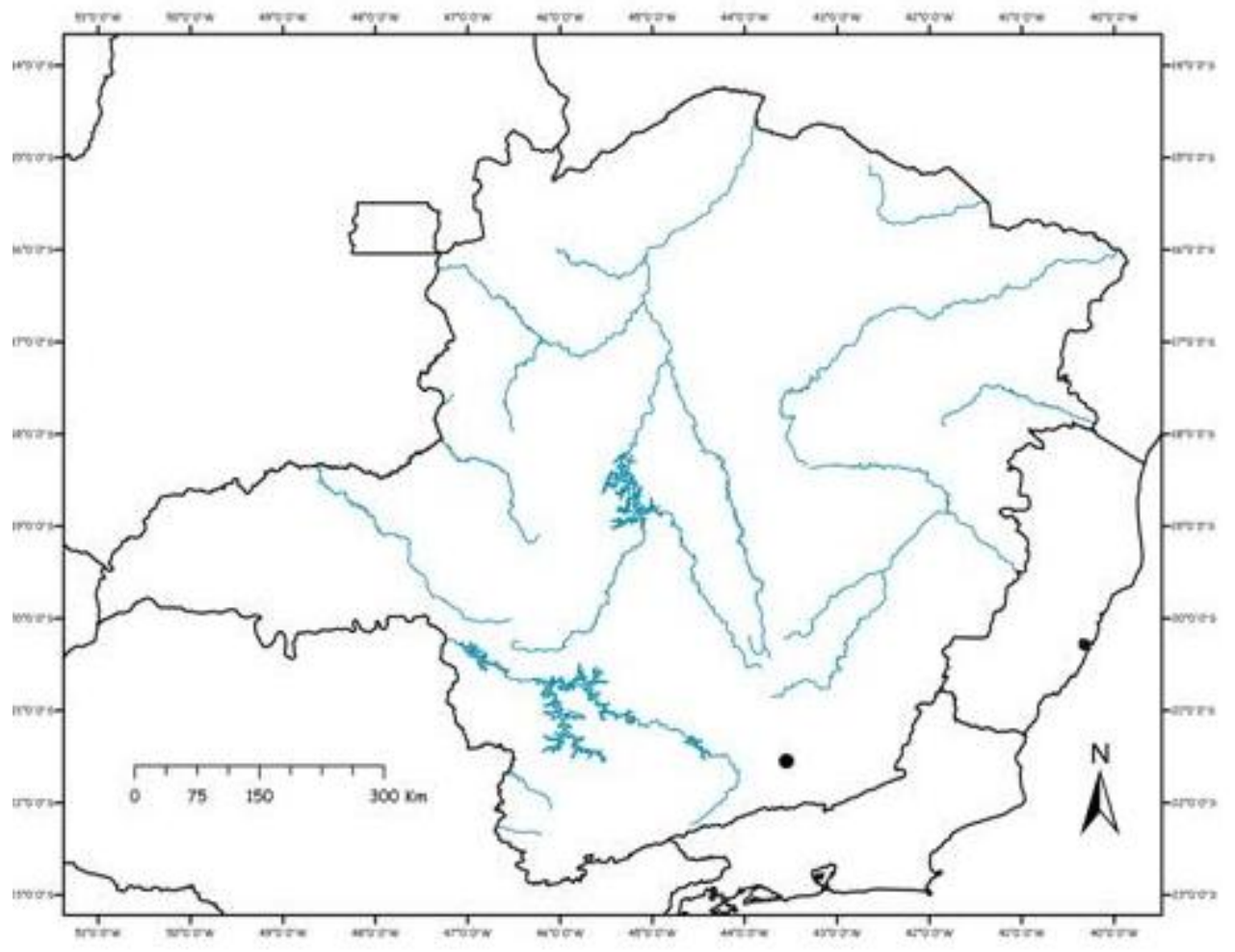

Figura 42: Mapa de distribuição geográfica de B. neocomensium • 

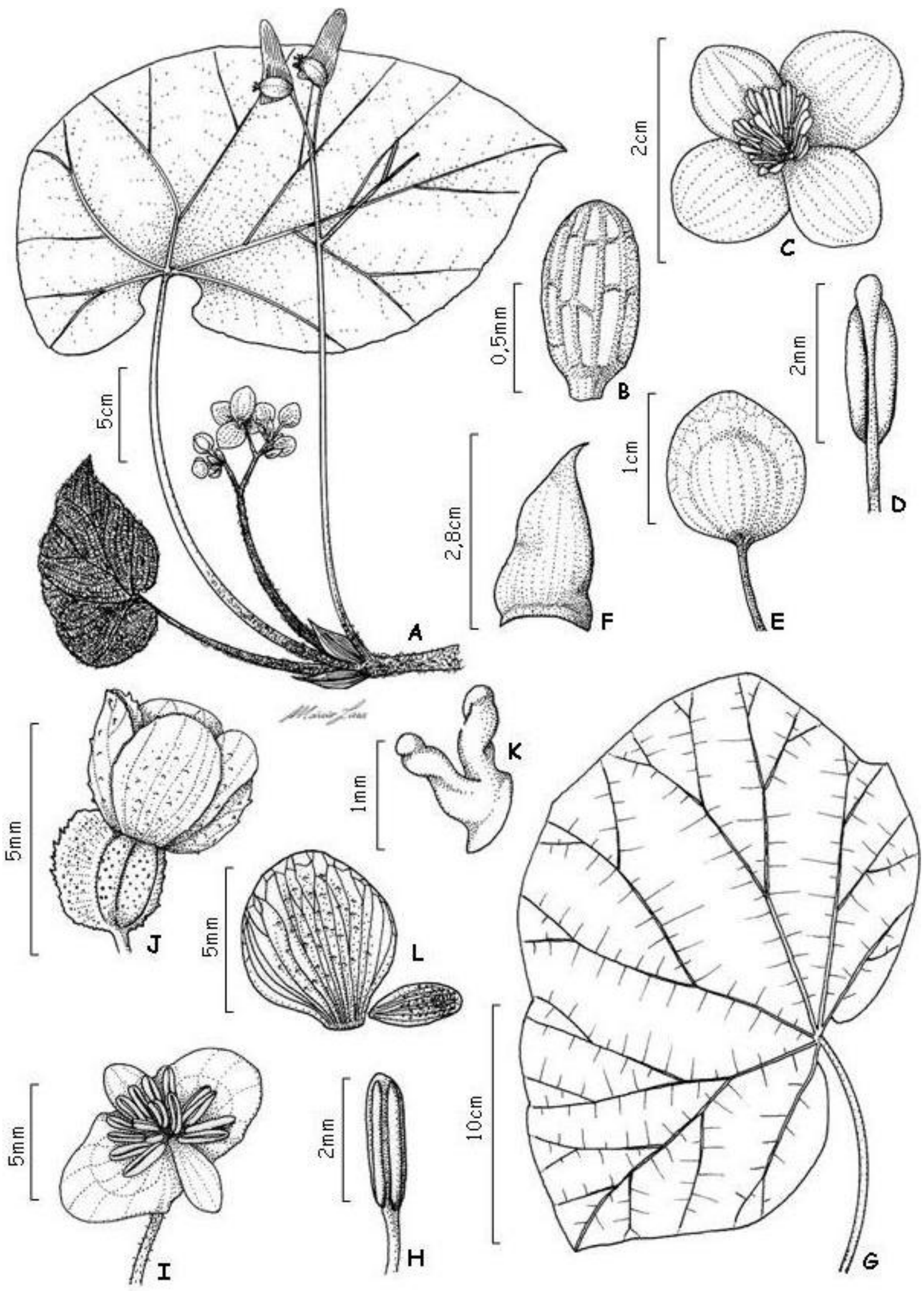

Figura 43: A-F: B. moysesij: A- hábito; B- semente; C- flor estaminada; D- estame; Eflor estaminada (botão); F- estípula. G-L: B. neocomensiun G- folha; H- estame; I- flor estaminada; J- flor pistilada; K- estigma; $\mathbf{L}-$ dorso das tépalas da flor estaminada. [ $A_{-}-\mathrm{F}$ : Mh. Kuhlmann, 2401 (SP); G-K: H.G.P. Santos, s.n. (SP 359201)]. 
4.4.23. Begonia aff. nuda Irmsch., Bot. Jahrb. Syst., 76:58, 1953.

(PRANCHA: fig.46: A-D, pág.101; MAPA: fig.44, pág.100)

ERVAS carnosas, glabriúsculas, tricomas simples muito esparsos acima dos nós mais jovens dos caules e sob as nervuras principais na face abaxial das folhas, e tricomas glandulares muito esparsos nas tépalas das flores pistiladas e nas alas das cápsulas, ca. $1,5 \mathrm{~m}$ alt. CAULES ca. $0,5 \mathrm{~cm}$ diâm., eretos, suculentos, cilíndricos, estriados, simples, avermelhados, glabros, tricomas esparsos presentes somente um pouco acima dos nós mais jovens; entrenós $0,7-1,5 \mathrm{~cm}$ comp. ESTÍPULAS ca. 1,3cm comp., aprox. 0,4cm larg., triangulares, ápice acuminado, base truncada, margem inteira, papiráceas, caducas, apressas, glabras. FOLHAS com pecíolos 3,5-7cm comp., cilíndricos, estriados, glabros; lâminas $11-17 \mathrm{~cm}$ comp., $6-8 \mathrm{~cm}$ larg., inteiras, basifixas, papiráceas, oblíquas, ovais a oblongo-lanceoladas, assimétricas, ápice acuminado, base cordada, margem irregularmente denteada, glabras em ambas as faces, exceto as nervuras da face abaxial, estas com tricomas muito esparsos, verdes em ambas as faces, venação actinódroma 5-6 nervuras. CIMEIRAS 20-30 flores 5-6 nós; pedúnculos ca. $19 \mathrm{~cm}$ comp., glabros; brácteas 1 par, comp., larg., forma, ápice, base e margem não vistos, caducas, indumento não visto. FLORES ESTAMINADAS não vistas; bractéolas 1-3 pares, comp., larg., forma, ápice, base e margem não vistos, caducas, indumento não visto. FLORES PISTILADAS tépalas 5, semelhantes entre si, 3-4mm comp., ca. $1 \mathrm{~mm}$ larg., elípticas a obovais, ápice obtuso, base truncada, margem inteira, tricomas glandulares muito esparsos, alvas a róseas; pedicelos $0,7-1 \mathrm{~cm}$ comp., tricomas glandulares muito esparsos; bractéolas 1-3 pares, ca. 0,5mm comp., aprox. 0,3mm larg., triangulares, ápice acuminado, base truncada, margem inteira, inseridas nos nós das cimeiras, caducas; estiletes ca. 1,5mm comp.; estigmas aprox. 0,5mm comp., ramos cilíndricos e espiralados, hipanto com glândulas translúcidas. CÁPSULAS 5-8mm comp., 0,8-1 cm larg., tépalas, estiletes e bractéolas caducos, região locular 4-5mm diâm., placentas inteiras; alas diferentes entre si, sendo a ala maior ascendente; ala maior 4-5mm larg., ápice obtuso; alas menores ca. $1 \mathrm{~mm}$ larg. SEMENTES oblongas.

DISTRIBUIÇÃo E HÁBITATS: Begonia aff. nuda é uma espécie endêmica do Estado de Minas Gerais, encontrada no Vale do Jequitinhonha, nos domínios da Mata Atlântica, habitando locais ensolarados como orlas de mata.

FLORAÇÃO E FRUTIFICAÇÃO: floresce e frutifica no mês de outubro.

COMENTÁRIOS: Begonia aff. nuda é distinta de seu congênere pela presença de indumento (um pouco acima dos nós mais jovens dos caules e sob as nervuras das folhas na face abaxial), por tricomas glandulares muito esparsos no dorso das tépalas das flores pistiladas e nas alas das cápsulas e pelas características apresentadas na tabela IX, pág.97.

Embora as flores estaminadas do único espécime de Begonia aff. nuda para o Estado de Minas Gerais não foram examinadas, as diferenças observadas são suficientes 
para a conclusão de que Begonia aff. nuda é um novo registro de Begonia para a flora de Minas Gerais e, muito provavelmente, uma novidade para a ciência.

Tabela IX: Características diagnósticas entre Begonia aff. nuda e Begonia nuda Irmsch.

\begin{tabular}{|c|c|c|}
\cline { 2 - 3 } \multicolumn{1}{c|}{} & Begonia aff. nuda & B. nuda \\
\hline Pecíolos & completamente glabros & glabros, com um colar de tricomas no ápice \\
\hline Estípulas & triangulares & elípticas \\
\hline Alas das cápsulas & $\begin{array}{c}\text { diferentes entre si, } \\
\text { sendo a ala maior ascendente } \\
\text { com ápice agudo }\end{array}$ & semelhantes entre si \\
\hline Sementes & oblongas & cilíndricas \\
\hline Distribuição geográfica & $M G$ & SP \\
\hline
\end{tabular}

Material examinado: BRASil. Minas Gerais. Pedra Azul, $8 \mathrm{~km}$ a oeste da cidade, na estrada para a rodovia BR 116 - Colaboração do IBUSP, Universidade de São Paulo (SPF) e R.B.G. Kew (K) - patrocínio do National Geographic Society, 18.X.1988, Harley, R.M. 25158, et al. (SPF). 
4.4.24. Begonia paulensis A. DC., Ann. Sci. Nat., Bot. IV, 11:125, 1859.

Begonia binotii hort. ex C. Chevalier, Begonias, :256, 1938.

(PRANCHA: fig.101: E-J, pág.99; MAPA: fig.45, pág.100)

ERVAS hirsutas, indumento esparso formado por tricomas simples, longos e por escamas fimbriadas, até $60 \mathrm{~cm}$ alt. CAULES 0,5-1cm diâm., decumbentes, suculentos, estriados, simples a pouco ramificados, verdes, hirsutos e geralmente com um aglomerado de estípulas e escamas na base; entrenós 0,2-0,4cm comp. ESTÍPULAS $2-3 \mathrm{~cm}$ comp., $1-2 \mathrm{~cm}$ larg., elípticas, ápice acuminado, base obtusa, margem inteira a levemente ondulada, papiráceas, persistentes, apressas e com tricomas simples no dorso. FOLHAS com pecíolos (10,5-)15-25,5cm comp., estriados, envolvidos por tricomas simples e escamas fimbriadas; lâminas (12-)18-20cm comp., (7,5-)11-13cm larg., inteiras, peltadas, membranáceas, ovais a largamente ovais, ligeiramente assimétrica, ápice acuminado, margem serreado-crenada ciliada, indumento distribuído mais densamente na face abaxial, face adaxial verde, face abaxial avermelhada, venação actinódroma, 5-6 nervuras no ápice do pecíolo. CIMEIRAS 8-15 flores, 3-5 nós; pedúnculo $16-43,5 \mathrm{~cm}$ compr., com tricomas simples esparsos. brácteas 1 par, 0,5cm comp., 0,3cm larg., ovais, ápice obtuso, base truncada, margem inteira, caducas, com tricomas simples no dorso. FLORES ESTAMINADAS tépalas 4, as externas 1,0-1,5cm comp., 0,3-0,5cm larg., obovadas, ápice arredondado, base arredondada, margem inteira, com tricomas simples, as internas 1-1,3cm comp., 0,2-0,3cm larg., elípticas, ápice arredondado, base aguda a cuneada, margem inteira, glabras, alvas; pedicelos 2-3cm comp., glabros; bractéolas 1-3 pares, 0,3-0,7cm comp., 0,2-0,3cm larg., ovais, ápice agudo, base truncada, margem inteira a levemente ondulada, caducas, com tricomas simples; estames 30-40, ca. $1 \mathrm{~mm}$ comp., filetes livres; anteras $2-2,5 \mathrm{~mm}$ comp., rimosas, oblongas. FLORES PISTILADAS tépalas 5, subiguais, 0,5-2,3cm comp., 0,3-2,5cm larg., ápice agudo, base arredondada, margem levemente crenada, glabras, alvas; pedicelos $2-3 \mathrm{~cm}$ comp., com tricomas simples; bractéolas 1-3 pares, 0,2-0,7cm comp., 0,1-0,3cm larg., ovais, ápice agudo, base truncada, margem inteira a levemente ondulada, inseridas no ápice do pedicelo, caducas, com tricomas simples; estiletes ca. $1 \mathrm{~mm}$ comp.; estigmas 1,5-3mm comp., ramos cilíndricos e espiralados; hipanto com tricomas simples. CÁPSULAS 0,9-1,5cm comp., 3$4 \mathrm{~cm}$ larg., tépalas, estiletes e bractéolas caducos, região locular $0,8 \mathrm{~cm}$ diâm., placentas partidas, alas diferentes entre si; ala maior 2-2,5cm larg., levemente ascendente, ápice agudo a obtuso; alas menores ca. $3 \mathrm{~mm}$ larg. SEMENTES oblongas.

DISTRIBUIÇÃO E HÁBITATS: Begonia paulensis é uma espécie endêmica da Serra da Mantiqueira. Esta espécie é muito frequente na região de Passa Quatro, sendo encontrada nos domínios da Mata Atlântica e habitando locais sombrios ou iluminados, porém, sempre associadas à cursos d'água e às vezes sobre pedras.

FLORAÇÃO E FRUTIFICAÇÃO: floresce nos meses de abril e maio e frutifica no mês de julho. 
COMENTÁRIOS: Begonia paulensis apresenta como características únicas entre as espécies de Begonia de Minas Gerais a lâmina peltada (bulada in vivo) e o indumento formado por tricomas simples, longos e por escamas fimbriadas. Possui também similaridades morfológicas com Begonia moysesii Brade e Begonia sp., discutidas na tabela $X$ a seguir:

Tabela X: Características diagnósticas entre Begonia paulensis, Begonia moysesii e Begoniasp.

\begin{tabular}{|c|c|c|c|}
\cline { 2 - 4 } \multicolumn{1}{c|}{} & B. paulensis & B. moysesii & Begonia sp. \\
\hline Folhas & pelatadas & basifixas & peltadas \\
\hline \multirow{3}{*}{ Folhas/forma } & $\begin{array}{c}\text { ovais a largamente } \\
\text { ovais, ápice } \\
\text { acuminado }\end{array}$ & $\begin{array}{c}\text { elípticas a ovais, } \\
\text { ápice } \\
\text { acuminado }\end{array}$ & $\begin{array}{c}\text { largamente ovais a } \\
\text { orbiculares, ápice agudo ou } \\
\text { arredondado }\end{array}$ \\
\hline Indumento & $\begin{array}{c}\text { hirsuto, tricomas simples, } \\
\text { longose }\end{array}$ & $\begin{array}{c}\text { aracnóide, tricomas } \\
\text { simples finos e longos e } \\
\text { tricomas glandulares }\end{array}$ & glabras \\
\hline \multirow{2}{*}{ Estípulas } & $\begin{array}{c}\text { escamas fimbriadas } \\
\text { inteira com levemente } \\
\text { ondulada e tricomas no } \\
\text { dorso }\end{array}$ & $\begin{array}{c}\text { ovais com margem } \\
\text { irregularmente ondulada, }\end{array}$ & $\begin{array}{c}\text { induriangulares com } \\
\text { margem irregular, } \\
\text { as vezes ciliada, } \\
\text { glabras }\end{array}$ \\
\hline
\end{tabular}

MATERIAL EXAMINADO: BRASIL. Minas GeraIs. Passa Quatro, Estação Experimental Mant. I.N.P., 3.V.1948, Brade, A.C. 18935, \& Araújo, S. (RB); Serra Fina, região do Ibama. Floresta Montana, 23.IV.2007, Meireles. L.D. 3072, \& Nunes, J.A. (UEC).

MATERIAL ADICIONAL EXAMINADO: BRASIL. RIO DE JANEIRO. Itatiaia, km 950, 22.V.1935, Brade, A.C. 14556 (RB). BRASIL. ESTADO? 10.VII.1945, Sampaio, J.J. s.n. (RB 148861). 


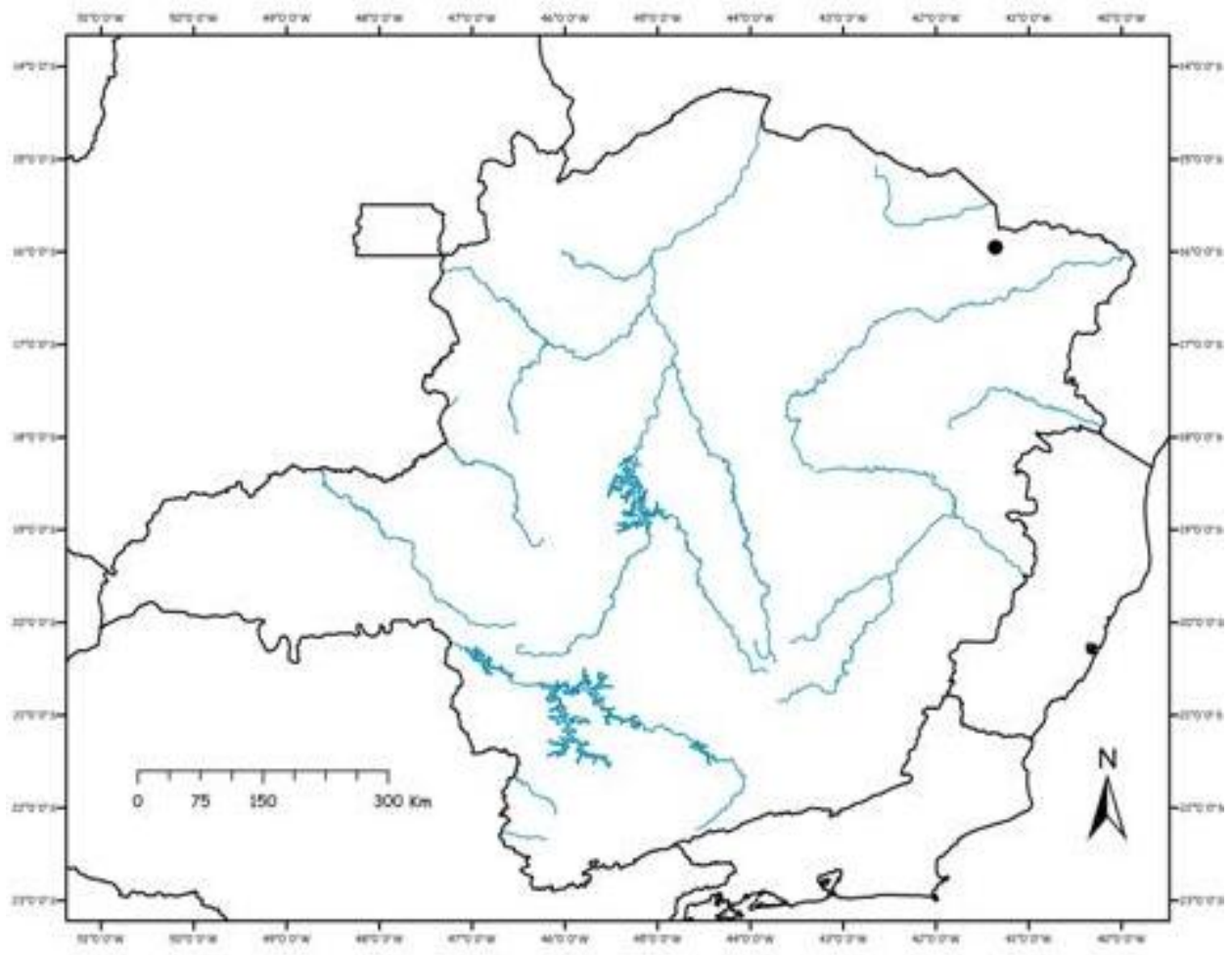

Figura 44: Mapa de distribuição geográfica de Begonio aff. nucb

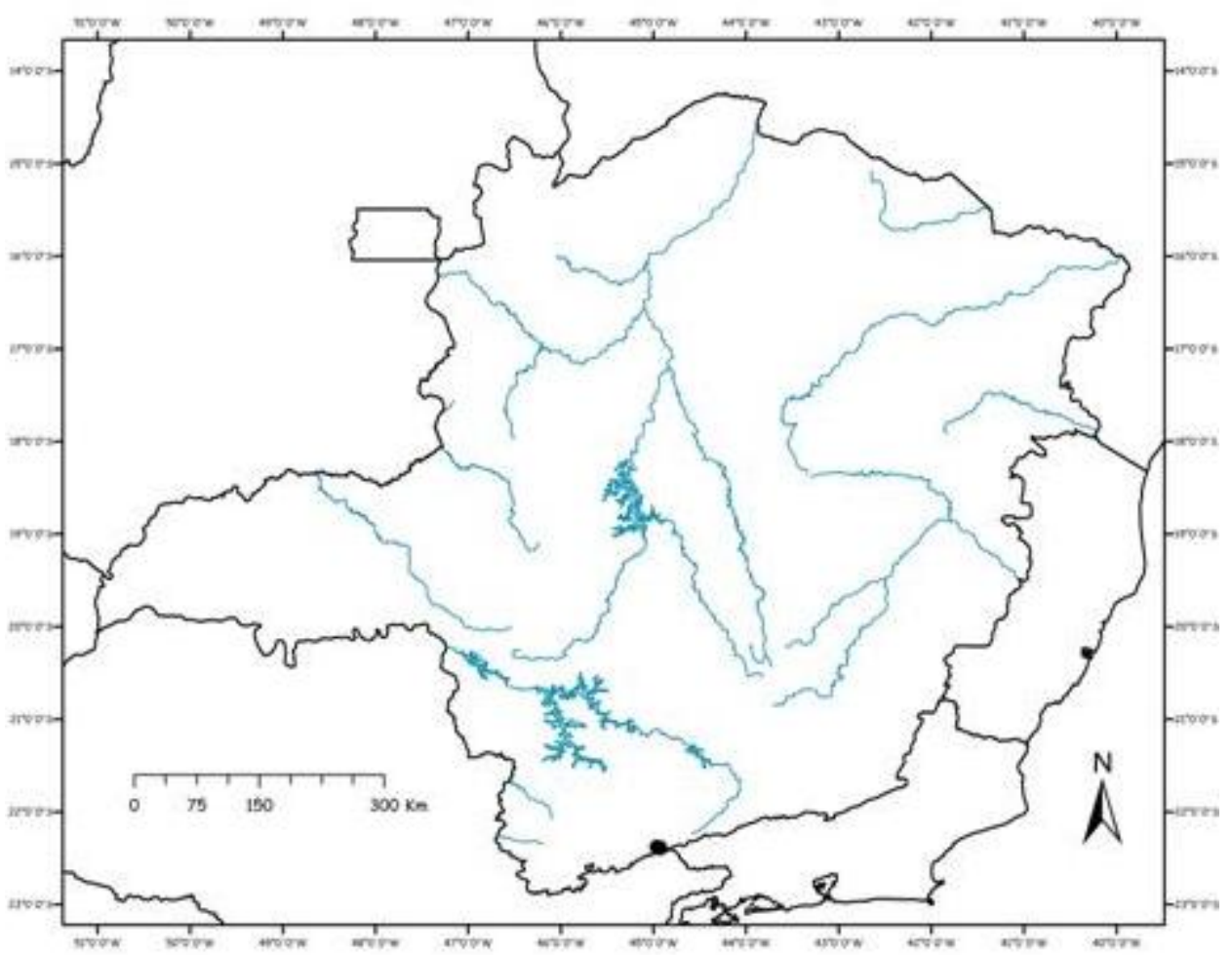

Figura 45: Mapa de distribuição geográfica de B. paulensis 


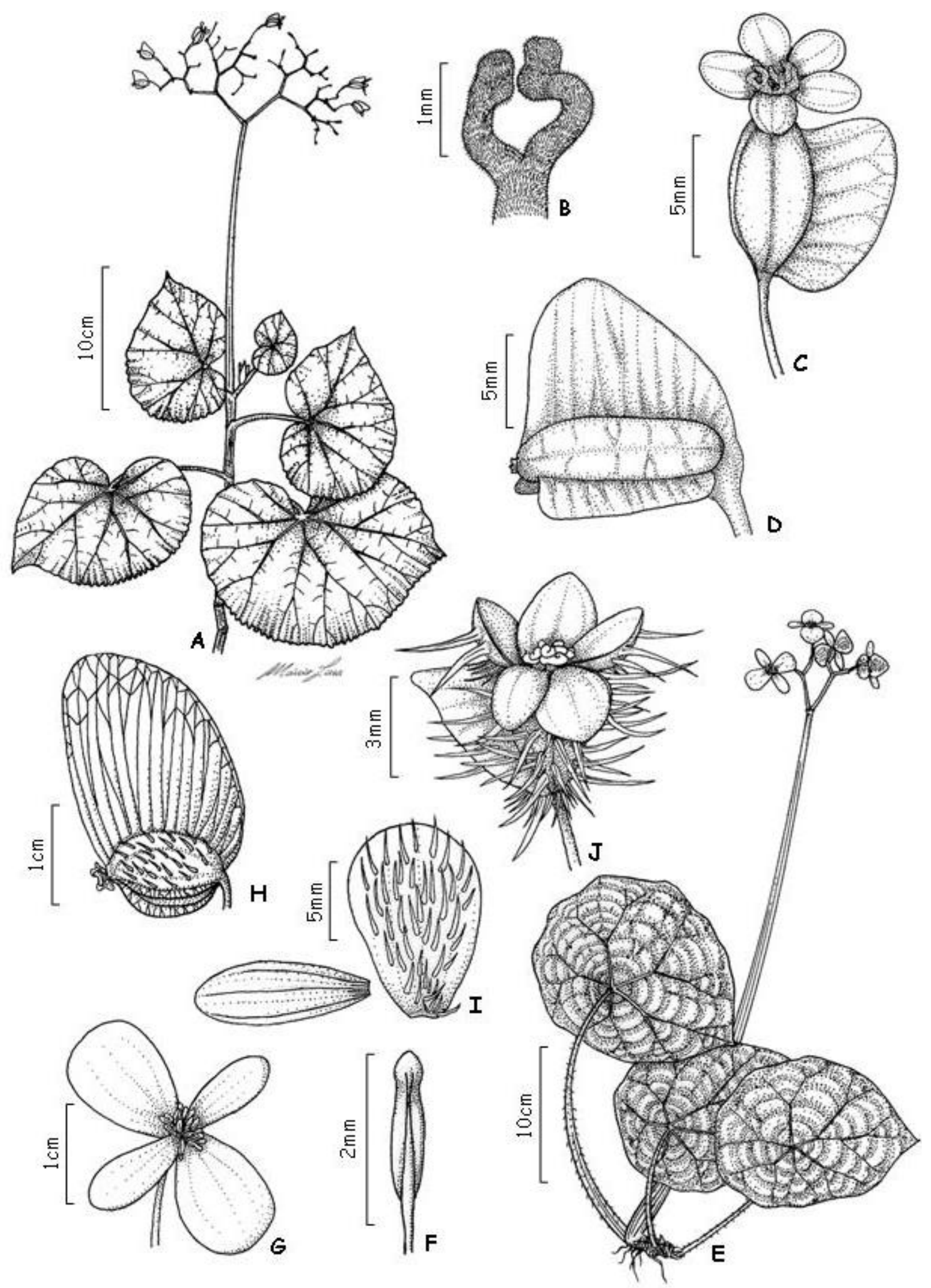

Figura 46: A-D: Begonia aff. nuda A- hábito; B- estigma; $C$ - flor pistilada; D- cápsula. E-J: $\boldsymbol{B}$. paulensis E- hábito; F- estame: G- flor estaminada; H- cápsula; I- face abaxial das tépalas da flor estaminada. [A-D: R.M. Raley, 25158 et al (ESA). E- A.C. Brade, 1455 (RB); F-G: L.D. Meireles, 3072 \& J.A. Nunes (UEC); H: J.J. Sampaio, s.n. (RB 148861)). 
Begonia washingtoniana hort. ex C. Chevalier, Begonias, :350, 1938 pro syn.

(PRANCHA: fig.49: A-F, pág.108; MAPA: fig.47, pág.107)

ERVAS carnosas, tomentosas, glabrescentes, tricomas simples, curtos e tricomas glandulares, $1-1,5 \mathrm{~cm}$ alt. CAULES $0,5-1,5 \mathrm{~cm}$ diâm., eretos, suculentos, cilíndricos, estriados, pouco ramificados, verdes a avermelhados, glabrescentes; entrenós (0,5-)2$3,5 \mathrm{~cm}$ comp. ESTÍPULAS 1-1,5cm comp., 0,4-0,8cm larg., ovais a triangulares, ápice agudo a acuminado, base truncada, margem irregularmente ondulada, ciliada, papiráceas, caducas apressas, tomentosas. FOLHAS com pecíolos $3-8,5 \mathrm{~cm}$ comp., cilíndricos, estriados, glabrescentes; lâminas $16-22 \mathrm{~cm}$ comp., 10-13cm larg., palmatilobadas, 57 palmatífidas, incisões profundas, mas não ultrapassando a metade da distância entre a margem e o ponto de irradiação das nervuras, basifixas, membranáceas, oblíquas, lobos deltóides, lâminas reniformes a assimétricas, lobos com ápices agudos, base cordada, margem serrilhada, ciliada, glabrescentes, indumento mais concentrado sob as nervuras na face abaxial, face adaxial verde, face abaxial avermelhada, palmatinérvea, 4-5 nervuras na base. CIMEIRAS 20-30 flores, 3-4 nós; pedúnculos (3-)4-5,5cm comp., glabrescentes; brácteas 1 par, 1-2,5cm comp., 0,5-1cm larg., ovais a largamente ovais, ápice obtuso a agudo, base truncada, margem inteira, ciliada, caducas, tomentosas, tricomas simples e tricomas glandulares. FLORES ESTAMINADAS tépalas 4 , as externas 1-2,3cm comp., 1-1,5cm larg. ovais a largamente ovais, ápice obtuso a arredondado, base arredondada, margem inteira a levemente ondulada, tomentosas, tricomas simples e tricomas glandulares, as internas $1-1,7 \mathrm{~cm}$ comp., 0,5-0,7cm larg., elípticas, ápice obtuso a arredondado, base aguda, margem inteira, com uma crista de tricomas esparsos no dorso, alvas a róseas; pedicelos $1-1,5 \mathrm{~cm}$ comp., tomentosos; bractéolas 1-2 pares, 1-1,5cm comp., 0,3-0,7cm larg., elípticas a ovais, ápice acuminado a obtuso, raramente arredondado, base truncada, margem inteira, ciliada, tardiamente caducas, tomentosas, tricomas simples e tricomas glandulares; estames 50-65, ca. 3mm comp., filetes livres; anteras aprox. $1 \mathrm{~mm}$ comp., rimosas, oblongas, as vezes elípticas. FLORES PISTILADAS tépalas 4, semelhantes entre si, uma delas ligeiramente diferente no tamanho, 1,5-2,5(-3)cm comp., 1,5-2,5cm larg., obovais, ápice obtuso a arredondado, base truncada, margem levemente ondulada, ciliada, glabrescente, somente tricomas simples, alvas a róseas; pedicelos 1-1,5(-2,5)cm comp., tomentosos; bractéolas 1-3 pares, 1-1,5cm comp., 0,3-0,7cm larg., elípticas a ovais, ápice acuminado a obtuso, raramente arredondado, base truncada, margem inteira, ciliada, um par inserido logo abaixo do hipanto e os demais nos nós das cimeiras, tardiamente caducas, tomentosas, tricomas simples e tricomas glandulares; estiletes 4-5mm comp.; estigmas 1-2mm comp., hipanto tomentoso. CÁPSULAS ca. $2,5 \mathrm{~cm}$ comp., aprox. $3,5 \mathrm{~cm}$ larg., tépalas, estiletes e bractéolas caducos, região locular ca. $1,3 \mathrm{~cm}$ diâm., placentas partidas; alas diferentes entre si, sendo a ala maior ligeiramente maior no tamanho que as demais; ala maior ca. $1,3 \mathrm{~cm}$ larg., ápice obtuso a arredondado; alas menores aprox. $0,7 \mathrm{~cm}$ larg. SEMENTES oblongas. 
DISTRIBUIÇÃO E HÁBITATS: Begonia platanifolia ocorre na Zona da Mata mineira, nos domínios da Mata Atlântica, habitando locais úmidos e sombreados tais como matas ciliares.

FLORAÇÃO E FRUTIFICAÇÃo: floresce nos meses de janeiro, abril e maio e frutifica no mês de maio.

COMENTÁRIOS: Begonia platanifolia é uma espécie caracterizada pelo indumento tomentoso, formado por tricomas simples, curtos e por tricomas glandulares e pelas lâminas palmatífidas com incisões profundas, não ultrapassando a metade da distância entre a margem e o ponto de irradiação das nervuras. Esta espécie possui insigne potencial ornamental evidenciado pelas cimeiras com flores vistosas e, portanto, habitualmente é cultivada em jardins. As cápsulas Begonia platanifolia são bastante semelhantes às cápsulas de Begonia toledoana Handro, podendo ser prontamente diferenciadas pelas folhas inteiras em Begonia toledoana, contrapondo com as lâminas palmatífidas de Begonia platanifolia. Esta espécie também possui similaridades morfológicas com Begonia gardneri A. DC. e Begonia reniformis Dryand., sendo e distinta destas espécies pelas características apresentadas na tabela VIII, pág.61.

MATERIAL EXAMINADO: BRASIL. Minas GeraIs. Carangola, Fazenda São Martinho. Área perturbada, resquício de mata ciliar, 7.IV.1991, Leoni, L.S. 1472 (SP). Carangola, Fazenda São Martinho. Resquício de mata ciliar, 31.II.2001, Leoni, L.S. 4582, et al. (SP). Muriaé, Arredores de Minas, 12.V.1983, Hatschbach, G. 46298 (BHCB, MBM). 
4.4.26. Begonia reniformis Dryand., Trans. Linn. Soc., 1:161, 1791.

Begonia vitifolia Schott, in Sprengel, Syst, Veg., 4(app):407, 1827.

Begonia longipes W.J. Hooker, Bot. Mag., 57:pl. 3001, 1830.

Begonia truncata Vell., FI. flum., icon., 10:pl. 47, "1827", 1831; descr., Arch. Mus. Nat. Rio de Janeiro, 5:406, 1881.

Begonia grandis Otto, Allg. Gartenzeitung, 4:349, 1836, non Dryander, 1791, pro syn.

Begonia elatior hort. ex Steudel, Nom. Bot., ed 2, 1:193, 1840, pro syn.

Wageneria reniformis (Dryand.) Klotzsch, Monatsber, Königl. Preuss. Akad. Wiss. Berlin, :126, 1854.

Wageneria vitifolia (Schott) Klotzsch., Monatsber, Königl. Preuss. Akad. Wiss. Berlin, :126, 1854; Abh. Königl. Akad. Wiss. Berlin 1854, :236, 1855.

Begonia vitifolia hort. Berol. ex Klotzsch, Abh. Königl. Akad. Wiss. Berlin 1854, :238, 1855.

Wageneria longipes (W.J. Hooker) Klotzsch, Abh. Königl. Akad. Wiss. Berlin 1854, :237, 1855.

Begonia longipes W.J. Hooker var. laticordata A, DC., in Martius, FI. bras., 4(1):368, 1861.

Begonia vitifolia Schott var. bahiensis A. DC., in Martius, F. bras., 4(1):369, 1861.

Begonia vitifolia Schott var. grandis A. DC., in Martius, F. bras., 4(1):369, 1861.

Begonia huberi C. de Candolle, in Huber, Bull. Herb. Boissier, II, 1:315, 1901.

Begonia palmifolia hort. ex Buxton, Begonias, :33, 1932.

Begonia inermis Irmscher, Bot. Jahrb. Syst., 76:39, 1953.

Begonia reniformis auct. non Dryand.: W.J. Hooker, Bot. Mag., 60:pl. 3225, 1833.

(PRANCHA: fig.49: G-K, pág.108; MAPA: fig.48, pág.107)

ERVAS, tomentosas, tricomas simples, ferrugíneos, até $1,80 \mathrm{~m}$ alt. CAULES $0,5-5 \mathrm{~cm}$, eretos, suculentos, estriados, simples, glabrescentes, tricomas simples; entrenós $2-5 \mathrm{~cm}$. ESTÍPULAS 1-2cm comp., 0,3-1cm larg., triangulares, ápice agudo a acuminado, base truncada, margem inteira, membranáceas, caducas, apressas, glabras. FOLHAS com pecíolos 6,5-11cm comp., estriados, glabrescentes, tricomas simples; lâminas $17-30 \mathrm{~cm}$ comp., 9-20cm larg., palmatilobadas, 4-7palmatífidas, incisões superficiais, basifixas, papiráceas, reniforme, lobada, assimétrica, lobos triangulares com ápices agudos a acuminados, base cordada, margem irregularmente denticulada, esparsamente ciliada, glabrescente em ambas as faces, sendo o indumento distribuído mais densamente na face abaxial e sob as nervuras (face abaxial), face adaxial verde, face abaxial verde a avermelhada, palmatinérvea, 4-6 nervuras na base. CIMEIRAS 70-150 flores, 5-6 nós; pedúnculos 10,5-25cm comp., glabrescente, tricomas simples; brácteas 1 par, ca. $5 \mathrm{~mm}$ comp., 1-2mm larg., triangulares, ápice acuminado, base truncada, margem inteira, caducas, glabras. FLORES ETAMINADAS tépalas 4, as externas aprox. $6 \mathrm{~mm}$ comp., ca. $5 \mathrm{~mm}$ larg., obovais, ápice obtuso a arredondado, base arredondada, margem inteira, glabras, as internas ca. $5 \mathrm{~mm}$ comp., aprox. $1 \mathrm{~mm}$ larg., elípticas, ápice agudo, base aguda, margem inteira, glabras alvas a róseas; pedicelos $0,5-1,5 \mathrm{~cm}$ comp., tricomas esparsos, 
simples; bractéolas 1-3 pares, ca. $2 \mathrm{~mm}$ comp., aprox. $1 \mathrm{~mm}$ larg., triangulares, ápice acuminado, base truncada, margem inteira, persistentes, glabras; estames 15-20, ca. $4 \mathrm{~mm}$ comp., filetes livres; anteras 2-2, $\mathrm{mm}$ comp., rimosas, oblongas. FLORES PISTILADAS tépalas 5, semelhantes entre si, ca. $6 \mathrm{~mm}$ comp., 1-2mm larg., elípticas, ápice obtuso, base truncada, margem inteira, glabras, alvas a róseas; pedicelos 0,5$1,2 \mathrm{~cm}$, tricomas esparsos, simples; bractéolas 1-3 pares, ca. $2 \mathrm{~mm}$ comp., aprox. $1 \mathrm{~mm}$ larg., triangulares, ápice acuminado, base truncada, margem inteira, um par inserido abaixo do hipanto e os demais diretamente no pedicelo, persistentes, glabras; estiletes 3-4mm comp.; estigmas ca. $2 \mathrm{~mm}$ comp., ramos cilíndricos e espiralados, hipanto glabro. CÁPSULAS aprox. $1 \mathrm{~cm}$ comp., 1,5-2,3cm larg., tépalas e bractéolas caducos e estiletes persistentes, região locular 0,4-09cm diâm., placentas inteiras diferentes entre si, sendo a ala maior ascendente; ala maior $1-2 \mathrm{~cm}$ larg., ápice agudo a obtuso; alas menores ca. $1 \mathrm{~mm}$ larg. SEMENTES obovais.

DISTRIBUIÇÃO E HÁBITATS: Begonia reniformis ocorre nas regiões Central, Norte e Sul de Minas Gerais, no Vale do Jequitinhonha, Alto São Francisco e na Zona da Mata, em áreas dominadas por Mata Atlântica, Cerrado, campos rupestres e Caatinga, habitando geralmente locais com altitude acima dos $700 \mathrm{~m}$, tanto locais iluminados quanto locais sombrios e úmidos, às vezes entre rochas.

FLORAÇÃO E FRUTIFICAÇÃO: floresce e frutifica no período de junho a outubro.

COMENTÁRIOS: Begonia reniformis é uma espécie altamente polimórfica. Na obra original, o autor faz referência a folhas inteiras, de margem dentada, no entanto, em Begonia reniformis sensu Silva (1998), as folhas são 5-7lobadas de margem denticulada a serrilhada e em Begonia reniformis sensu Jacques (1999) as folhas são irregularmente lobadas com margem serreada a serrilhada. Nos materiais de Minas Gerais analisados, no geral, observou-se folhas palmatilobadas, 4-7palmatífidas, com incisões superficiais e margem irregularmente denticulada. Além disto, verificou-se também que o ápice da ala maior das cápsulas pode ser agudo a obtuso e que as variações do formato da lâmina e do indumento são acompanhadas por variações no tamanho dos pecíolos e pedúnculos. Como os extremos de tais variações são muito discrepantes, verifica-se uma grande dificuldade (ou mesmo impossibilidade) em se estabelecer um padrão dentro de toda a plasticidade morfológica de Begonia reniformis. Portanto, faz-se necessário a avaliação dos espécimes procedentes das demais localidades onde se distribui a espécie e a análise da coleção tipo do nome em questão para a sua correta identificação.

Begonia reniformis também possui semelhanças morfológicas à Begonia gardneri A. DC. e Begonia platanifolia Schott, sendo prontamente distintas pelas características apresentadas na tabela VIII, pág.61.

MATERIAL EXAMINADO: BRASIL. MINAS GeraIs. Alto Caparaó, Encosta da Serra do Caparaó, abaixo Encostas da Serra do Caparaó, abaixo do Parque Nacional, 24.X.1989, Pirani, J.R. 2549, et al. (BHCB, SP, SPF); Serra do Caparaó. Vale Verde, 27.IX.1977, Coons, M.P. 77-1227, et al. (VIC); Parque Nacional do Caparaó. Estrada entre o alojamento e Vale Verde, 1.IX.1996, Souza, V.C. 12120, et al. (ESA); Parque Nacional do Caparaó. Vale Verde. Floresta aluvial, ao longo do Rio Caparaó, 16.II.2000, Souza, V.C. 23180, et al. (ESA). Barão de Cocais, 10.VII.1991, Pio 358 
(PAMG). Caparaó, Parque Nacional do Caparaó, Vele Verde, 15.VI.1991, Hatschbach, G. 55544, et al. (MBM); Parque Nacional do Caparaó. Vale Verde, 27.IX.1977, Krieger, L. 77-1226, et al. (VIC). Coronel Pacheco, Fazenda Carlota, 27.IV.1945, Heringer, E.P. 1885 (RB). Itaú de Minas, Cachoeira do Rio Santa Anna, IV.1945, Brade, A.C. 18017, \& Altamiro (RB). Januária, Vale do rio Peruaçu, na trilha para o Sítio Arqueológico de Desenhos e Troncos, 22.VII.1997, Salino, A. 3363, \& Stehmann, J.R. (ESA). Monte Belo, Fazenda Lagoa. Mata Lagoa, disturbed semideciduous forest, 6.IX.1987, Gentry, A. 59099, et al. (UEC). Ouro Fino, Campos naturais úmidos, 7.V.1927, Hoehne, F.C. s.n. (SP 19495). Ouro Preto, Estação Ecológica do Tipuí - Fora das áreas de amostragens, 16.V.1994, Nunes, Y.R.F. s.n., et al. (HXBH 12015). Pains, Mineração Vale do São Miguel. Região cárstica, mata seca decidual sobre afloramento calcáreo próximo ao Rio São Miguel, 11.VII.2006, Borges, R.A.X. 146, \& Bernardo, P.H. (RB); Mineração Vale do São Miguel. Região cárstica, afloramento calcáreo com predominância de espécies rupícolas de Cactaceae $e$ Bromeliaceae, 13.VII.2006, Borges, R.A.X. 183, \& Bernardo, P.H. (RB); Mineração Vale do São Miguel. Região cárstica, mata seca decidual sobre afloramento calcáreo próximo ao Rio São Miguel, 11.VII.2006, Borges, R.A.X. 208, \& Bernardo, P.H. (RB). Poços de Caldas, Morro do Ferro, 8.III.1983, Leitão Filho, H.F. 2027, et al. (UEC); Rodovia São João da Boa Vista - Poços de Caldas, Perez, J.M.A s.n. (ESA 3761). Salto da Divisa, 15-20 km 0, 18.VII.1988, Hatschbach, G. 52225, \& Silva, J.M. (MBM). Santana do Riacho, Cardeal Mota. Morro da Pedreira ( $2^{\circ}$ grupo). Afloramentos calcáreos na base da Serra do Cipó. Fazenda Canto da Serra, 22.VII.1993, Campos, M. T.V.A. s.n., et al. (ESA 102863); Conceição do Mato Dentro, ao longo da Rodovia Belo Horizonte - Conceição do Mato Dentro. Atalho para o Morro do Calcáreo, 7.X.1981, Kawasaki, M.L. s.n., et al. (SPF 20385); Serra do Cipó: Morro do Calcáreo, ao longo da rodovia Belo Horizonte - Conceição do Mato Dentro., 19.VI.1987, Zappi, D.C. s.n. \& Kameyama, C. (SPF 47797). Senador Bento, 16.VII.1999, Brandão, M. 29271 (PAMG). Sete Lagoas, In forest on limestone hill, 10km west of Sete Lagoas, 19.VI.1945, Williams, L.O. 7301, \& Assis, V. (RB). 


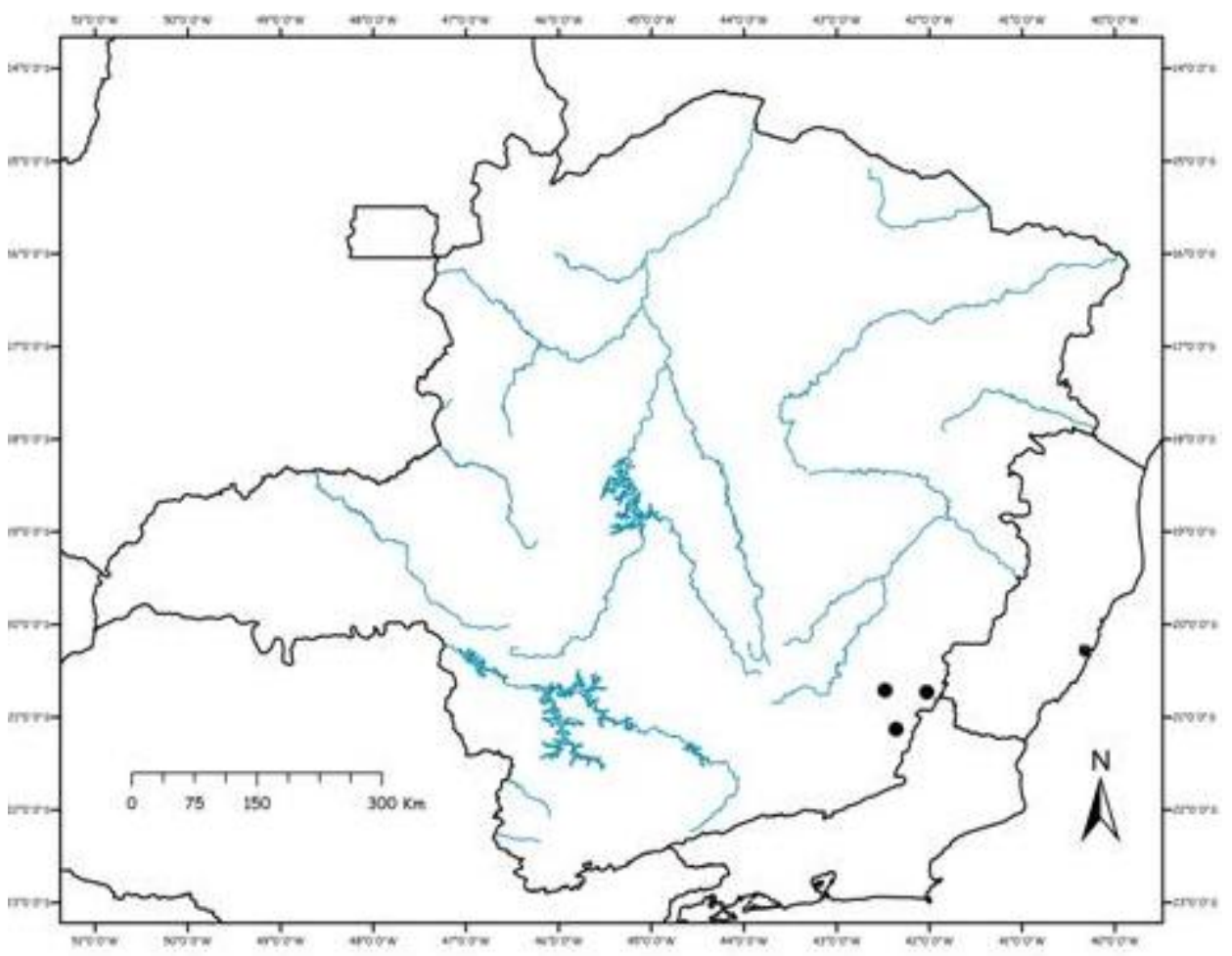

Figura 47: Mapa de distribuição geográfica de B. plotonifolio

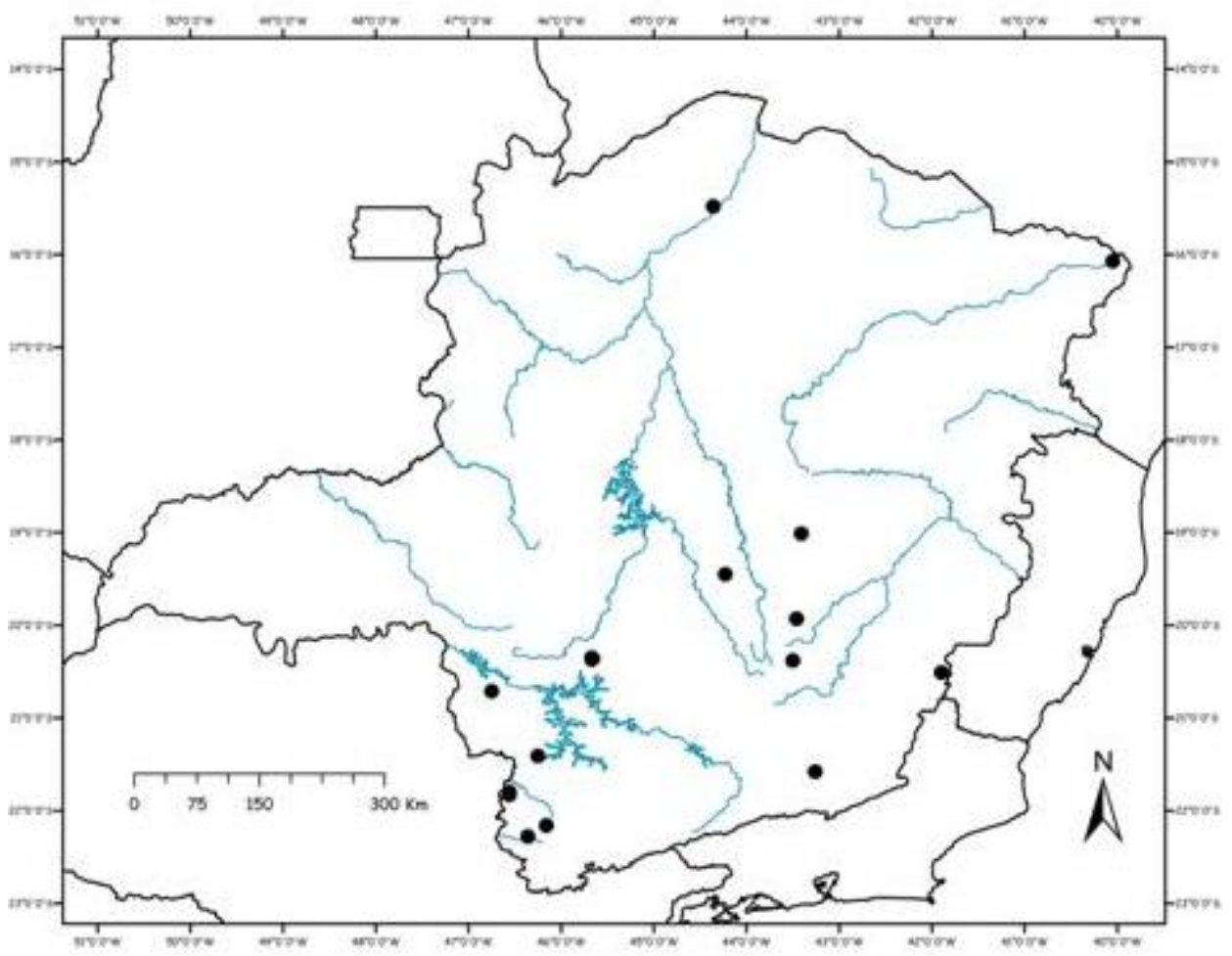

Figura 48: Mapa de distribuição geográfica de B. reniformis 


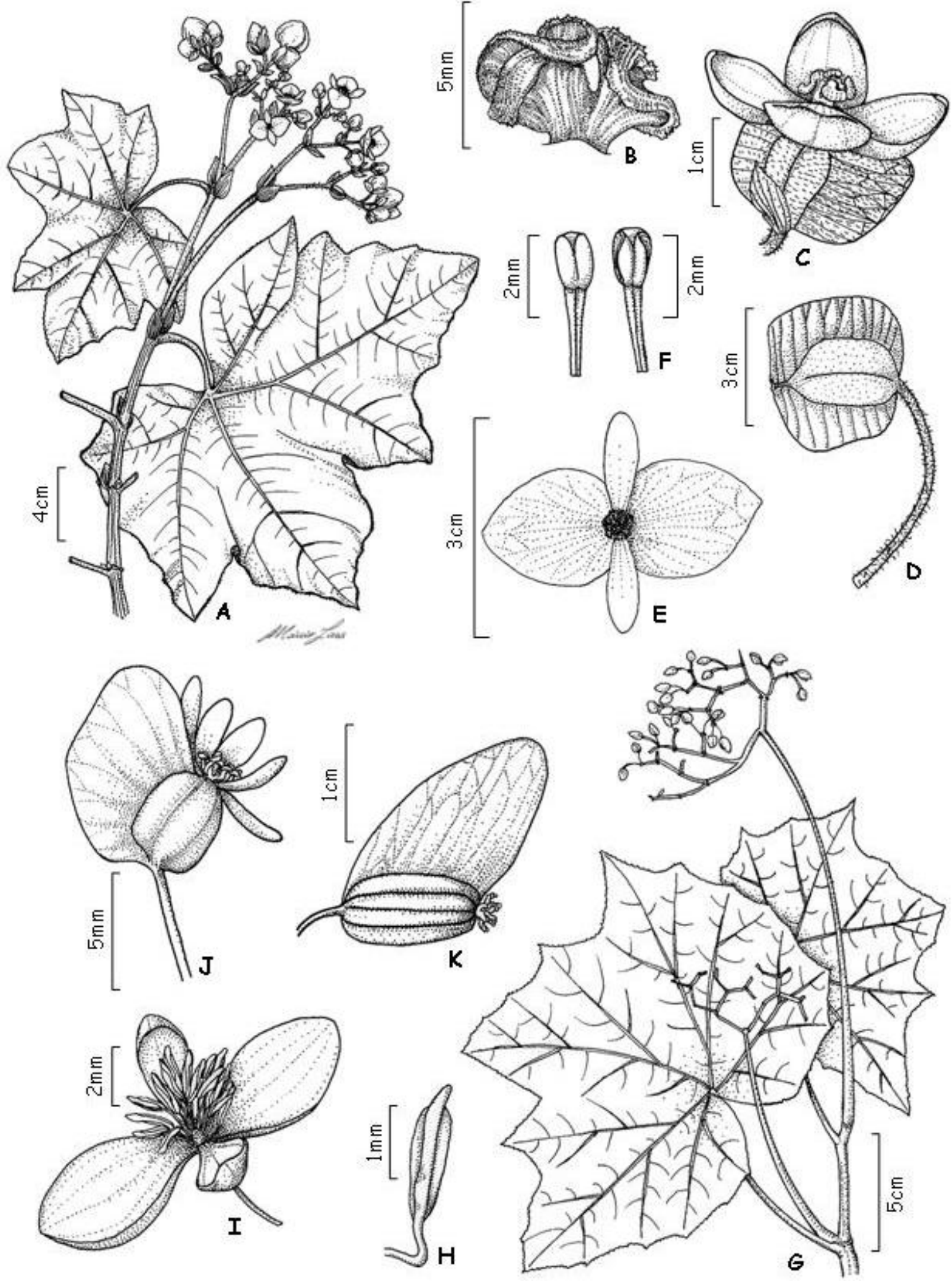

Figura 49: A-F: B. platanifolia A- hábito; B- estigma; $C$ - flor pistilada; D- cápsula; Eflor estaminada; F- estame. G-K: $\boldsymbol{B}$. reniformis: G- hábito; H- estame; I- flor estaminada; J- flor pistilada; K- cápsula; [A: L.S. Leoni, 4582 et al (GFJP): B-F: G. Hatschbach, 46298 (BHCB), G: D.C. Zappi, s.n. \& C. Kameyama (SPF 47797); H-J: J.R. Pirani 2549 et al (SPF); K: Pio, 358 (PAMG)]. 
4.4.27. Begonia riedelii A. DC., Ann. Sci. Nat. Bot., IV, 11:137, 1859.

(PRANCHA: fig.52: A-F, pág.117; MAPA: fig.50, pág.116; FOTOS: fig.53: A-C, pág.118)

ERVAS robustas, glabras, até 2,5m alt. CAULES (0,3-)0,5-1cm diâm., eretos, suculentos, estriados, simples a pouco ramificados, verdes a avermelhados, glabros; entrenós (2-)3$7 \mathrm{~cm}$ comp. ESTÍPULAS 2-3,5cm comp., 0,5-1,1cm larg., triangulares, ápice agudo, base truncada, margem inteira, membranáceas, persistentes, apressas, glabras. FOLHAS com pecíolos (5-)5,5-16,5cm comp., estriados, glabros, com colar de tricomas curtíssimos no ápice; lâminas 17-34,5cm comp., 7-13,5cm larg., 4-5(-6)lobadas, basifixas, papiráceas, transversais a oblíquas, elípticas, assimétricas, lobos com ápices agudos a acuminados, base cordada a profundamente cordada, margem irregularmente ondulada a denteada, glabras em ambas as faces, verdes em ambas as faces, venação actinódroma, 3-5 nervuras na base. CIMEIRAS 50-200 flores, 4-6 nós; pedúnculo 15-36,2cm comp., glabros; brácteas 1 par, 1-1,5cm comp., 0,3-0,5cm larg., triangulares a elípticas, ápice agudo, base truncada, margem inteira, caducas, glabras. FLORES ESTAMINADAS tépalas 4, as externas 0,5-1cm comp., 0,3-0,4cm larg., ovais a largamente ovais, ápice arredondado, base arredondada, margem inteira, glabras, as internas 0,5-1cm comp., 0,1$0,3 \mathrm{~cm}$ larg., elípticas, ápice agudo, base aguda, margem inteira, glabras, alvas a róseas; pedicelos 0,5-0,9cm comp., glabros; bractéolas 1-3 pares, 3-4 mm comp., ca. $2 \mathrm{~mm}$ larg., triangulares, ápice agudo, base truncada, margem inteira, tardiamente caducas, glabras; estames 25-30, aprox. 3mm comp., filetes livres; anteras ca. $2 \mathrm{~mm}$ comp., rimosas, oblongas. FLORES PISTILADAS tépalas 5, uma delas ligeiramente desigual no tamanho e na forma, 0,5-0,8cm comp., 0,2-0,3cm larg., ovais a largamente ovais, ápice arredondado, base truncada, margem inteira, glabras, alvas a róseas; pedicelos 0,50,9cm comp., glabros; bractéolas 1-3 pares, 3-4mm comp., ca. $2 \mathrm{~mm}$ larg., triangulares, ápice agudo, base truncada, margem inteira, inseridas no pedicelo, tardiamente caducas, glabras; estiletes aprox. $1 \mathrm{~mm}$; estigmas ca. $1 \mathrm{~mm}$ comp., ramos cilíndricos e espiralados; hipanto glabro. CÁPSULAS 0,7-1,3cm comp., 1-2,3cm larg., estiletes persistentes, tépalas e bractéolas caducos, região locular 0,5-07cm diâm., placentas inteiras; alas diferentes entre si, sendo a maior levemente ascendente; ala maior 1-1,5cm larg., ápice agudo a obtuso; alas menores ca. $1 \mathrm{~mm}$ larg. SEMENTES oblongas.

DISTRIBUIÇÃO E HÁBITATS: Begonia riedelii é uma erva robusta, heliófila encontrada na Zona da Mata mineira, nos domínios da Mata Atlântica, próximas a cursos d'água, formando grandes populações.

FLORAÇÃO E FRUTIFICAÇÃo: floresce e frutifica nos meses de março e julho.

COMENTÁRIOS: Begonia riedelii é uma espécie caracterizada pelas lâminas lobadas com ápices agudos a acuminados, pelos pecíolos glabros com um colar curtíssimo de tricomas no ápice, pelas estípulas triangulares, persistentes e pela caducidade das brácteas de ambas as flores. Compartilha com Begonia valdensium A. DC. algumas características, tais como o colar de tricomas no ápice do pecíolo e a persistência das estípulas, no entanto, estas espécies podem ser prontamente diferenciadas pelo fato desta última apresentar folhas inteiras a levemente lobadas, pela persistência das bractéolas e pela 
forma das estípulas, ovais a oblongo-lanceoladas em Begonia valdensium, contrapondo com estípulas triangulares em Begonia riedelii.

MATERIAL EXAMINADO: BRASIL. Minas GeraIs. Araponga, Parque Estadual da Serra do Brigadeiro. Trilha do Mucuri. Margem do Córrego Serrinha. 1300-1325 m.s.m., 23.III.2008, Delfini, C. 39, \& Paula-Souza, J. (ESA). Fervedouro, Parque Estadual da Serra do Brigadeiro, 10.VII.1999, Lombardi, J.A. 3119 (BHCB). 
4.4.28. Begonia rufa Thunb., Flora, 4:331, 1821.

Begonia lobata Schott in Sprengel, Syst. Veg., ed. 16, 4(app) :408, 1827.

Ewaldia ferruginea Klotzsch, Monatsber. Königl. Preuss. Akad. Wiss. Berlin, 126, 1854, nomen nudum; Abh. Königl. Akad. Wiss. Berlin 1854, :173, 1855; Begoniac., :53, 1855.

Ewaldia lobulata (Schott) Klotzsch, Monatsber. Königl. Preuss. Akad. Wiss. Berlin, 123, 1854; Abh. Königl. Akad. Wiss. Berlin 1854, :174, pl. 3C, 1855; Begoniac., :54, pl. 3C, 1855 .

Begonia galeotii hort. Berol. ex Klotzsch, Abh. Königl. Akad. Wiss. Berlin 1854, :174, 1855; Begoniac., :54, 1855, pro syn.

Begonia velutina hort. Vindob. ex Klotzsch, Abh. Königl. Akad. Wiss. Berlin 1854, :174, 1855; Begoniac., :54, 1855, pro syn .

Begonia vernicosa hort. Berol. ex Klotzsch, Abh. Königl. Akad. Wiss. Berlin 1854, :174, 1855; Begoniac., :54, 1855, pro syn.

(PRANCHA: fig.52: G-L, pág.117; MAPA: fig.51, pág.116; FotOs: fig.54: A-B, pág.118)

ERVAS robustas, tomentosas, tricomas simples, 0,4-2m alt. CAULES 0,5-2cm diâm., eretos, cilíndricos, estriados, ramificados, verdes a ferrugíneos, glabrescentes, tricomas simples; entrenós 2-10cm comp. ESTÍPULAS 1-2cm comp., 0,5-1cm larg., ovais a triangulares, ápice acuminado a mucronulado, base truncada, margem inteira a ondulada, membranáceas, tardiamente caducas, apressas, geralmente carinadas, carinas tomentosas, às vezes revestidas completamente no dorso, glabrescentes. FOLHAS com pecíolos 3-11(-15,5)cm comp., cilíndricos, estriados, tomentosos; lâminas 8-30(-31,5)cm comp., (4-)5-15cm larg., 3-4lobadas, basifixas, papiráceas a cartáceas, transversais, lobo terminal triangular, os demais ou, pelo menos um deles largamente oval, lâminas assimétricas, lobo terminal com ápice acuminado, os demais ou, pelo menos um deles com ápice/s arredondado/s a obtuso/s, base cordada, margem serrilhada, tomentosas em ambas as faces, indumento mais concentrado na face abaxial, face adaxial verde, às vezes com a margem avermelhada, face abaxial verde a avermelhada, venação actinódroma, 5-7 nervuras na base. CIMEIRAS 100-200 flores, 4-6 nós; pedúnculos (7,5-)11,5-34cm comp., glabrescentes; brácteas 1 par, 0,5-1cm comp., 0,3-0,5cm larg., ovais, ápice agudo a obtuso, base truncada, margem levemente ondulada, caducas, tomentosas. FLORES ESTAMINADAS tépalas 4, as externas 0,9-1,2cm comp., 0,7$1,2 \mathrm{~cm}$ larg., largamente elípticas a obovais, ápice arredondado, base arredondada, margem inteira a levemente ondulada, tomentosas, as internas 6-9mm comp., elípticas, ápice arredondado, base aguda, margem levemente ondulada, carinadas, carinas tomentosas ou glabras com uma crista de tricomas no dorso, alvas a róseas; pedicelos 0,9-1,2cm comp., tomentosas; bractéolas 1-4 pares, 4-9mm comp., 1-3mm larg., triangulares, ápice agudo a mucronulado, base truncada, margem levemente ondulada, caducas, tomentosas; estames 30-50, 3-4mm comp., filetes livres; anteras 2-3mm comp., rimosas, oblongas. FLORES PISTILADAS tépalas 5, uma delas ligeiramente diferente no tamanho e forma, 0,8-1,1 cm comp., 0,6-0,8cm larg., elípticas a obovais, ápice agudo a obtuso, base atenuada, margem inteira, serreada na metade superior, tomentosas, 
glabrescentes, alvas a róseas; pedicelos 0,5-2cm comp., tomentosas; bractéolas 1-4 pares, 4-9mm comp., 1-3mm larg., triangulares, ápice agudo a mucronulado, base truncada, margem levemente ondulada, inseridas nos pedicelos e nos nós das cimeiras, caducas, tomentosas; estiletes ca. $5 \mathrm{~mm}$ comp.; estigmas 2-3mm comp., hipanto tomentoso. CÁPSULAS 0,6-1,4cm comp., 1-2,5cm larg., estiletes persistentes, tépalas e bractéolas caducos, região locular 6-9 mm diâm., placentas inteiras; alas diferentes entre si, sendo a ala maior levemente ascendente; ala maior 0,5-1cm larg., ápice frequentemente arredondado, raramente obtuso; alas menores 1-2 mm larg. SEMENTES oblongas.

DISTRIBUIÇÃO E HÁBITATS: Begonia rufa é uma erva semi-heliófila que ocorre nas regiões Central e Sul de Minas Gerais, no Vale do Jequitinhonha, Vale do Rio Doce, na Zona da Mata, nas Vertentes e Alto São Francisco, em áreas dominadas pela Mata Atlântica, Cerrado, campos e campos rupestres, habitando interiores e orlas de matas, matas de encostas, matas de altitudes, matas de galeria, próximas à cursos d'água, solos arenosos, afloramentos rochosos e entre fendas de rochas.

FLORAÇÃO E FRUTIFICAÇÃO: floresce e frutifica praticamente o ano todo.

COMENTÁRIOS: Begonia rufa difere de seus congêneres pelas características apresentadas na tabela XI, a seguir:

Tabela XI: Características morfológicas de Begonia rufa, Begonia altamiroi e Begonia apparicioi.

\begin{tabular}{|c|c|c|c|}
\cline { 2 - 4 } \multicolumn{1}{c|}{} & B. rufa & B. altamiroi & B. apparicioi \\
\hline Folhas & 3-4lobadas & 3-4(-5)lobadas & 4(-5)lobadas \\
\hline Lobos das folhas & $\begin{array}{c}\text { lobo terminal triangular, os } \\
\text { demais ou, pelo menos um } \\
\text { deles largamente oval }\end{array}$ & $\begin{array}{c}\text { todos } \\
\text { os lobos } \\
\text { lanceolados }\end{array}$ & $\begin{array}{c}\text { todos } \\
\text { os lobos } \\
\text { triangulares }\end{array}$ \\
\hline Estípulas & ovais a triangulares & lanceoladas & lanceoladas \\
\hline Sementes & oblongas & oblongas & oblongas a lineares \\
\hline
\end{tabular}

Das três espécies, Begonia rufa é a melhor definida, no entanto, esta espécie é morfologicamente muito variável, principalmente a forma dos lobos das folhas $e$ indumento. Esta ampla variação de formas observada nesta espécie pode estar relacionada à sua distribuição e aos hábitats que ocupam, entretanto, existem sobreposições e formas intermediárias não constantes a ponto de permitir 0 reconhecimento de categorias infra-específicas, o que foi relacionado, então, à plasticidade fenotípica das populações estudadas. Além disso, como foram avaliados somente os espécimes de Minas Gerais e como não foram analisados os materiais da coleção tipo do nome em questão, optou-se tratar as populações de Begonia rufa como uma única espécie.

MATERIAL EXAMINADO: BRASIL. MINAS GERAIS. Barão de Cocais, Serra do Caraça, entre o Mosteiro e o Caraça, entre rochas, 12.X.1992, Souza, V.C. 2069, \& Sakuragui, C.M. (ESA). Belo 
Horizonte, Jardim Botânico., 6.II.1933, Barreto, M. 1837(BHCB); Arredores de Belo Horizonte, 5.VII.1960, Heringer, E.P. s.n., (MBM 22818). Caeté, Serra da Piedade, 10.IV.1933, Barreto, M. 1832 (BHCB); Serra da Piedade, segunda estação de coleta, 28.IV.1985, Elcione s.n., et al. (SPF 148103, ESA 80589); Serra da Piedade, 4.III.1976, Ferreira, M.B. 5516 (PAMG); Serra da Piedade, 28.XII.1975, Ferreira, M.B. 5614 (PAMG); Serra da Piedade, 27.III.1957, Pereira, E. 2661 (RB); Serra da Piedade. Alto da serra, 20.VII.1987, Pirani, J.R. s.n., et al. (SPF 61861); Serra da Piedade, 24.II.1987, Zappi, D.C. s.n. et al. (SPF 46860; MBM 254475). Camanducaia, Mata do Vaga, 1.VI.2001, Lombardi, J.A. 4381 (BHCB). Carandai, Crespo, 15.XI.1946, Duarte, A.P. 495 (RB). Catas Altas, 30.VII.1996, Brandão, M. 25479 (PAMG); Serra do Caraça. Seminário do Caraça. Mata no caminho para o campo de fora, 27.VII.1989, Cordeiro, I. 596, \& Romaniuc Neto, S. (ESA); Serra do Caraça, 4.VII.2002, Mota, R.C. 1635 (BHCB). Caxambu, Arredores de Caxambu, 13.VII.1954, Duarte, A.P. 3793 (RB). Conceição de Ibitipoca, Parque Florestal da Serra do Ibitipoca, 29.VI.1991, Salimensa-Pires, F.R. S.n., et al. (ESA 82631). Congonhas do Norte, Serra da Carapina (Serra Talhada na folha IBGE), setor N da Serra do Cipó, 2.III.1998, Pirani, J.R. 4136, et al. (SPF, MBM). Itabirito, 15.I.1951, Heringer, E.P. 2682 (RB); Pico do Itabirito. Morro do Galinheiro, Serra da Inconfidência, em local de vegetação mais densa, 11.III.1994, Teixeira, W.A. s.n. (BHCB 25049); Serra da Moeda, próximo a lanchonete Mirante da Serra, BR 040, 12.VII.2002, Viana, P.L. 649 (BHCB). Itamonte, Estrada para Itamonte. Beira da estrada, 22.III.2008, Delfini, C. 51, \& Paula-Souza, J. (ESA). Jaboticatubas, Serra do Cipó, 8.VIII.1972, Hatschbach, G. 30073 (MBM); Km 139 ao longo da rodovia Lagoa Santa - Conceição do Mato Dentro - Diamantina, 27.V.1972, Joly, A.B. 2169, et al. (UEC); Entre km 137-138, ao longo da Rodovia Lagoa Santa, Conceição do Mato Dentro, Diamamtina, 8.VI.1970, Joly, A.B. s.n., et al. (UEC 512). Lapinha, Mata aluvial em campo rupestre, 9.IX.1990, Amdt, M.A.L. s.n., \& Aristóbolo, M.S. (SP). Lima Duarte, Parque Estadual do Ibitipoca. Perto da caixa d'água, 15.X.1986, Andrade, P.M. 795, et al. (SP); Parque Estadual do Ibitipoca. Mata ao lado do camping, 17.XII.1986, Andrade, P.M. 847, \& Hilde, R. (SP); Parque Florestal da Serra do Ibitipoca, 14.VII.1977, Costa, J.M. s.n. (VIC 5194); Parque Estadual do Ibitipoca. Cachoerinha, 31.III.2004, Forzza, R.C. 3330, et al. (RB); Serra de Ibitipoca, 15.VI.1979, Krieger, L. 16237 (ESA); Parque Florestal da Serra do Ibitipoca, 13.VII.1997, Krieger, L. 77-1012, et al. (VIC); Distrito de Conceição do Ibitipoca, trilha descendo da lombada para a base do Parque. Solo arenoso, relevo íngrime, Mata ciliar - borda de mata, 26.IX.2001, Marquete, R. 3097, et al. (RB); Distrito de Conceição do Ibitipoca. Trilha para a Ponte de Pedra próximo ao Rio do Salto. Solo arenopedregoso, relevo íngrime. Campo rupestre, 8.V.2002, Marquete, R. 3213, et al. (RB); Distrito de Conceição de Ibitipoca. Parque Estadual do Ibitipoca. Entre Monjolinho e Lagoa Seca. Vegetação: Campo Rupestre, 29.VI.2004, Medeiros, E. 305, et al. (RB); Serra de Ibitipoca, 20.VIII.1992, Novelino, R.F. s.n., et al. (MBM 27915); Serra de Ibitipoca, Pico do Pião. Formações de Arenito da Série Lavras, 13.V.1970, Sucre, D. 6783, \& Krieger, L. (RB); Parque Estadual de Ibitipoca Caminho para a ponte da pedra, 13.VII.2005, Trovó, M.L.O. 173, et al. (SPF). Miguel Burnier, 31.I.1921, Hoehne, F.C. s.n., (SP 5243); 19.IV.1957, Pereira, E. 3013 (RB). Nova Lima, Morro do Chapéu, campo úmido de encosta, 2.VI.1982, Grandi, T.S.M. 1945, \& Andrade, P.M. (ESA); Iron hills, Serra do Curral, South of Belo Horizonte, 24.III.1945, Williams, L.0. 6346, \& Assis, V. (RB). Ouro Preto, 29.VI.1941, Barreto, M. s.n., \& Viegas, A.P. (SP 48966); Rancharia, 15.V.1979, Barroso 21 \& Ferreira (PAMG); Base do Itacolomi, 18.V.1979, Barroso 84 \& Ferreira (PAMG); Camarinhas, 1.VI.1980, Ferreira 7842 \& Cunha (PAMG); Estrada para Andorinhas, a $1 \mathrm{~km}$ da Escola de Farmácia de Ouro Preto, 4.VI.1978, Fontella 1078 (RB); Cachoeira das Andorinhas. Campo rupestre, 6.III.1982, Grandi, T.S.M. 881 (SP); Camarinhas., 6.VIII.1980, Lima, H.C. 1331, et al. (RB); Camarinhas, 6.VIII.1980, Lima, H.C. 1343, et al. (RB); Parque Estadual do Itacolomi, 13.V.1998, Lombardi, J.A. 2277 (SP); Cachoeira das Andorinhas, 23.V.1979, Mantone, L. 690, et al. (RB); Cachoeira das Andorinhas, 23.V.1979, Mantone, L. 703, et al. (RB); Serra das Camarinhas., 24.V.1979, Mantone, L. 779, et al. (RB); Serra da Camarinha, 24.V.1979, Mantone, L. 
795, et al. (RB); Campo rupestre, caminho para o Pico do Itacolomi, 17.VII.1978, Martinelli, G. 4746 (RB); Pico do Itacolomi, 15.V.1983, Moura, L.S. 401, \& Vieira, M.F. (VIC); Estação Ecológica do Tripuí, 16.V.1994, Nunes, Y.R.F. s.n., et al. (SPF 116462); Vargem de Pilatos, 11.VIII.1950, Oliveira, J.E. s.n. (BHCB 41616); Parque Estadual do Itacolomi, trilha do bau. Campo rupestre, 31.III.2000, Paula, C.C. 2005 (VIC); Estação Ecológica do Tipuí, VI.1999, Pedrali, G. s.n., et al. (HXBH 13323); Estação Ecológica do Tipuí, 10.III.1002, Pedralli s.n., et al. (HXBH 19146); Serra de Lavras Novas (Serra do Trovão), 18.VII.1998, Rapini, A. 683, et al. (SPF); 7.III.1994, Schwacke s.n. (RB 47527); Ex - Herbário Damásio, s.d., s.col. s.n. (RB47526); Camarinhas, 20.II.2002, Souza, V.C. 28073, et al. (ESA); Parque Estadual do Itacolomi, 13.V.1998, Temponi, L.G. 1 (BHCB); Itacolomi, 25.I.1901, Vasconcellos, S. s.n. (SP 18035). Passa Quatro, Fazenda Sertão dos Martins. Na mata, lugar sombrio, 22.IV.1948, Araújo, S. 140, \& Alt. Barb. (RB); Rio Retiro, 3.V.1948, Brade, A.C. 18954 \& Araújo, S. (RB); Estrada da Serra do Leite, 4.IV.1995, Moreira, J.L.A. 420, \& Belinello, R. (UEC). Prados, Serra São José, 7.VII.1991, Stehmann, J.R. s.n. (SP 263353). Santa Bárbara, Serra do Caraça, Parque Natural do Caraça, 19.IV.1997, Lombardi, J.A. 1598, et al. (SP, ESA, SPF); Serra do Caraça, 5.VIII.1975, Ferreira 5248, et al. (PAMG); Trilha para Campos de Flora-Serra do Canjerana, 8.III.1982, Hensold, N. s.n., et al. (SPF 22411); Serra do Caraça. Campos rupestres e matas de altitude, 12.XII.1978, Leitão Filho, H.F. 9503, et al. (UEC); Serra do Caraça. Trilha na floresta de enconta (com Vanillosmopsis) em direção ao Campo de Fora, 22.V.1997, Mello-Silva, R. 1345, et al. (SPF, BHCB); Serra do Caraça, caminho para a capelinha e Gruta de Lourdes, 27.V.1983, Pirani, J.R. 708, \& Yano, O. (SP, SPF); Serra do Caraça. Trilha do Pico do Carapuça, 23.V.1997, Rapini, A. 300, et al. (SP, SPF); Estrada Mariana - Santa Bárbara. Reserva da Companhia Vale do Rio Doce, 8.IX.1993, Semir, J. 28827, et al. (UEC); Serra do Caraça, 11.IX.1990, Stehmann, J.R. S.n., et al. (SP). Santa Rita de Ibitipoca, Na mata de galeria, 19.IV.1987, Krieger, L. 21420 (SPF). Santa Rita do Sapucaí, 20.VIII.1994, Brandão, M. 24369 (PAMG). Santana do Pirapama, Serra do Cipó (Serra da Lapa). Distrito de São José da Cachoeira. Trilha do João Carrinho. Campo rupestre, 18.II.2007, Souza, V.C. 32643, et al. (ESA). Santana do Riacho, Serra do Cipó. Retiro do Alto do Palácio, 25km NE de Cardeal Mota, caminho de Conceição do Mato Dentro. Campo Rupestre, entre rochas, 16.V.1990, Arbo, M.M. 4252, et al. (SPF); Serra do Cipó. Estrada do Pilar, km 143, 15.IV.1935, Barreto, M. 1062 \& Brade, A.C. (RB); Serra do Cipó, km 152 da estrada de Conceição do Mato Dentro, 30.IV.1950, Duarte, A.P. 2744 (RB); Serra do Cipó, km 138, estrada do Morro do Pilar, 13.II.1963, Duarte, A.P. 7577 (RB); Serra do Cipó, km 138, ao longo da Rodovia Belo Horizonte-Conceição do Mato Dentro, 15.XI.1984, Esteves, G.L. s.n., et al. (RB 273547); km 135 ao longo da rodovia Belo Horizonte - Conceição do Mato Dentro, 30.VI.1981, Giulietti, A.M. s.n., et al. (SPF 20259); km 142 ao longo da rodovia Belo Horizonte - Conceição do Mato Dentro., 11.X.1986, Godoy, S.A.P. s.n., et al. (SPF 44892); Rodovia Belo Horizonte - Conceição do Mato Dentro, km 143, aproximadamente $7 \mathrm{~km}$ além da bifurcação para Morro do Pilar. Fazenda Capão Redondo, 30.VIII.1998, Kameyama, V.L. s.n., et al. (SPF 71876); Serra do Cipó, km 127, afloramento de quartzito, 16.VII.1977, Martinelli, G. 2635 (RB); Serra do Cipó, km 138 ao longo da rodovia Belo Horizonte - Conceição do Mato Dentro, 23.VI.1980, Menezes, N.L. s.n., et al. (SPF 133678); Material examinado: Serra do Cipó. Campo rupestre (Afloramento rochoso), 16.VIII.1992, Pereira, M. 806, \& Lucca, M. (BHCB); Serra do Cipó, km 125 da rodovia Belo Horizonte-Conceição do Mato Dentro. Elevação em frente a estátua do Velho Juca. Vide suplemento, 29.VII.1991, Pirani, J.R. s.n., et al. (SPF 77807); km 132 ao longo da rodovia Belo Horizonte - Conceição do Mato Dentro, 30.X.1981, Sajo, M.G. s.n., \& Castro, N.M. (SPF 20405, MBM 85569); Serra do Cipó. Rodovia MG 010, km 117. BH. Conceição do Mato Dentro. Margem direita da estrada, 20.X.1997, Sano, P. T. 529, et al. (SPF); MG 010. Antigo km 135, pouco antes da bifurcação, lado direito da estrada Belo Horizonte - Conceição do Mato Dentro, 27.VII.1999, Sano, P. T. 976, et al. (ESA); Serra do Cipó, Salitreiro, próximo ao córrego lageado, 1.VI.1991, Simão-Bianchini, R. s.n. \& Bianchini, S. (SPF 80316); Serra do Cipó. Rodovia Belo Horizonte - Conceição do Mato 
Dentro. Próximo à bifurcação para Morro do Pilar, 5.VII.2001, Souza, V.C. 25086, et al. (ESA); Serra do Cipó. Rodovia Belo Horizonte - Conceição do Mato Dentro, km 119. Fazenda Cachoeira da Capivara, 28.II.2002, Souza, V.C. 28604, et al. (ESA); Serra do Cipó (Vellozia gigante). Entre rochas, 23.V.2996, Wanderley, M.G.L. 2080, et al. (ESA); Rodovia Belo Horizonte - Conceição do Mato Dentro, km 132. Serra da Salitreira. Parque Nacional da Serra do Cipó, próximo a sede, 12.VII.1987, Zappi, D.C. s.n., et al. (SPF 65687); km 125 ao longo da rodovia Belo Horizonte Conceição do Mato Dentro. Campo rupestre, 22.VII.1985, Zappi, D.C. s.n. (SPF 40384). Santo Antônio do Itambé, Subida para o Pico do Itambé a $12 \mathrm{~km}$ da cidade, 16.VII.1987, Zappi, D.C. s.n., et al. (SPF 63879). São José do Barreiro, ParNa da Canastra. Acesso pela portaria Casca D'Anta. Cachoeira Casca d'Anta., 2.X.2007, Delfini, C. 30, \& Romão, G.O. (ESA); ParNa da Canastra. Acesso pela portaria Casca D'Anta. Cachoeira Casca d'Anta, 2.X.2007, Delfini, C. 31, \& Romão, G.O. (ESA); São Roque de Minas, ParNa Serra da Canastra. Parte de baixo da Casca Danta, trilha para a cachoeira, 7.VII.1999, Farinaccio, M.A. 344A, et al. (ESA); Parque Nacional da Serra da Canastra. Capão de mata entre campo limpo, 17.VII.1997, Lombardi, J.A. 1866 (SP); Nascente do rio São Francisco, PARNA - Serra da Canastra, 16.X.1994, Romero, R. 1289, et al. (HUFU); Córrego do Quilombo, PARNA Serra da Canastra, 16.VII.1995, Romero, R. 2437, et al. (HUFU). São Tomé das Letras, Arredores de Minas, 28.II.1975, Hatschbach, G. 36564, et al. (MBM). Tiradentes, Serra de São José. $2 \mathrm{~km}$ NE of Tiradentes. Mata de Cerrado, in sandy umid substrate, Sciophyllous, III.1987, Alves, R.J.V. 310 (RB); 30.VI.1987, Leitão Filho, H.F. 19343, et al. (UEC). 


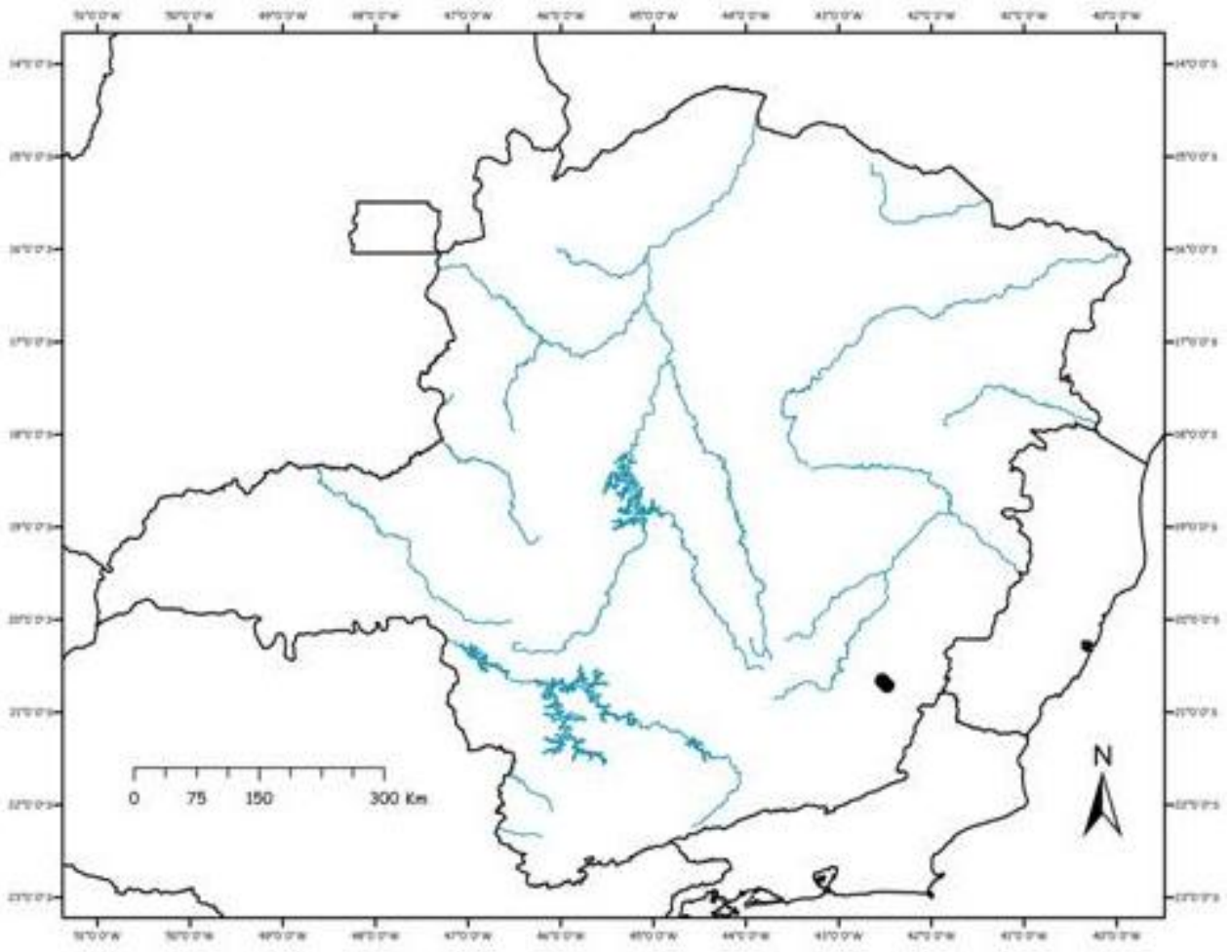

Figura 50: Mapa de distribuição geográfica de B. riedelij

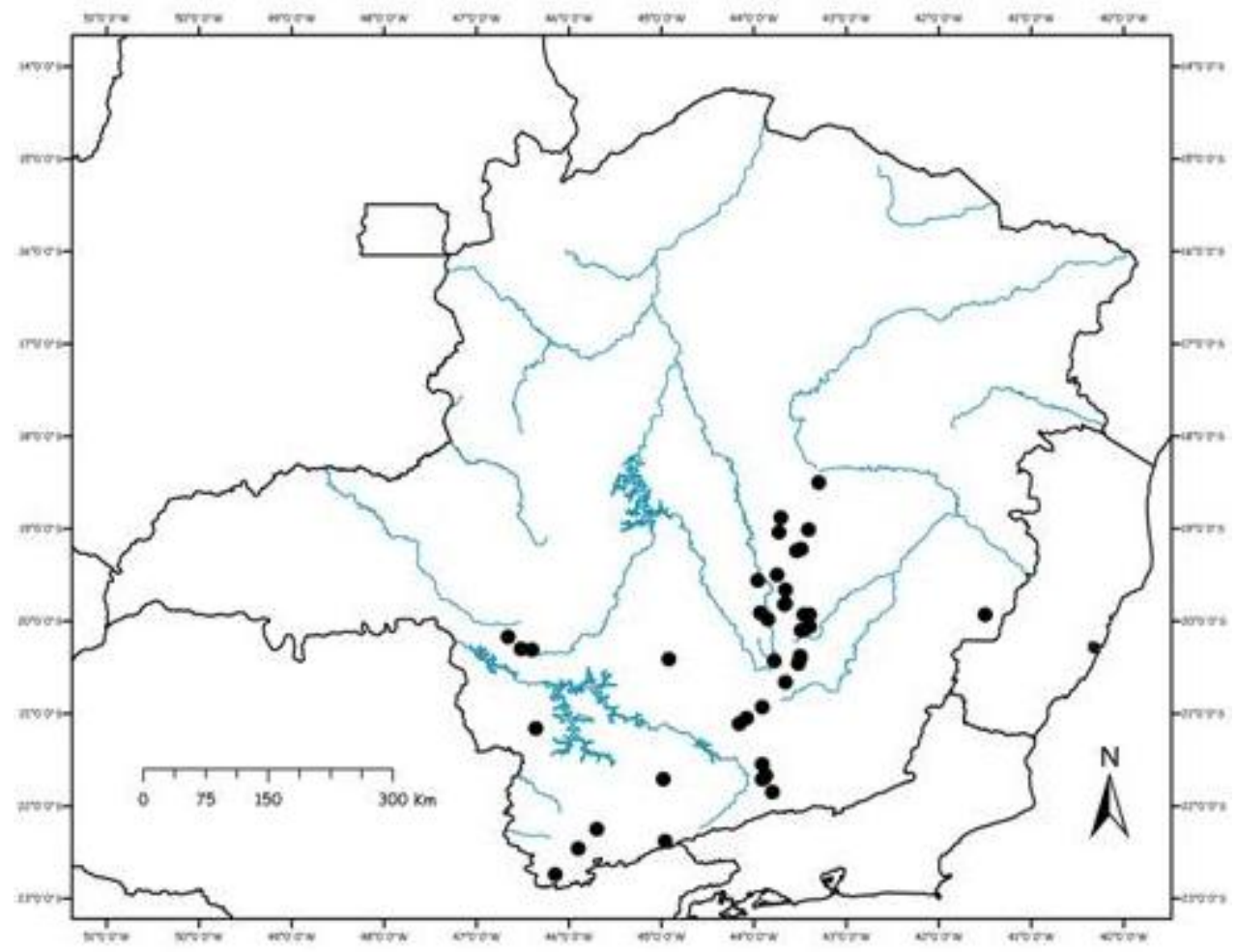

Figura 51: Mapa de distribuição geográfica de B. rufo 


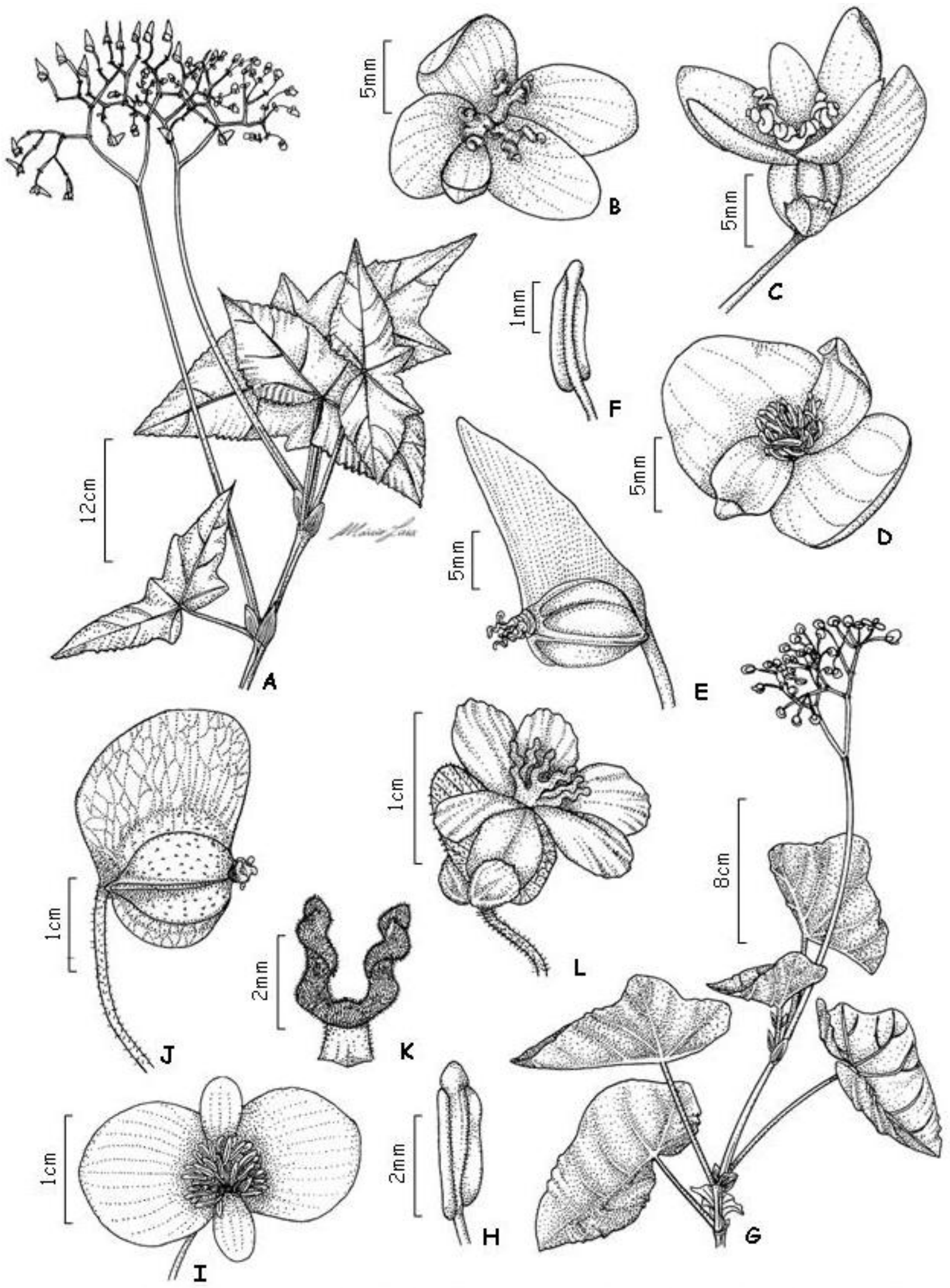

Figura 52: A-F: B. riedelii A- hábito; B- flor pistilada - detalhe do estigma; $\boldsymbol{C}$ - flor pistilada; D- flor estaminada; E- cápsula; F- estame. G-L: $\boldsymbol{B}$. rvfa G- hábito; H- estame; I- flor estaminada; J- cápsula; K- estigma; L- flor pistilada. [A-F: C. Delfini, 39 \& J. PaulaSouza (ESA). G: V.C. Souza, 25086 et al (ESA); H-I: P.M. Andrade, 847 \& R. Hilde (SP); J: P.M. Andrade, 795 et al (SP); K-L: R. Romero, 2437 et al (ESA)]. 

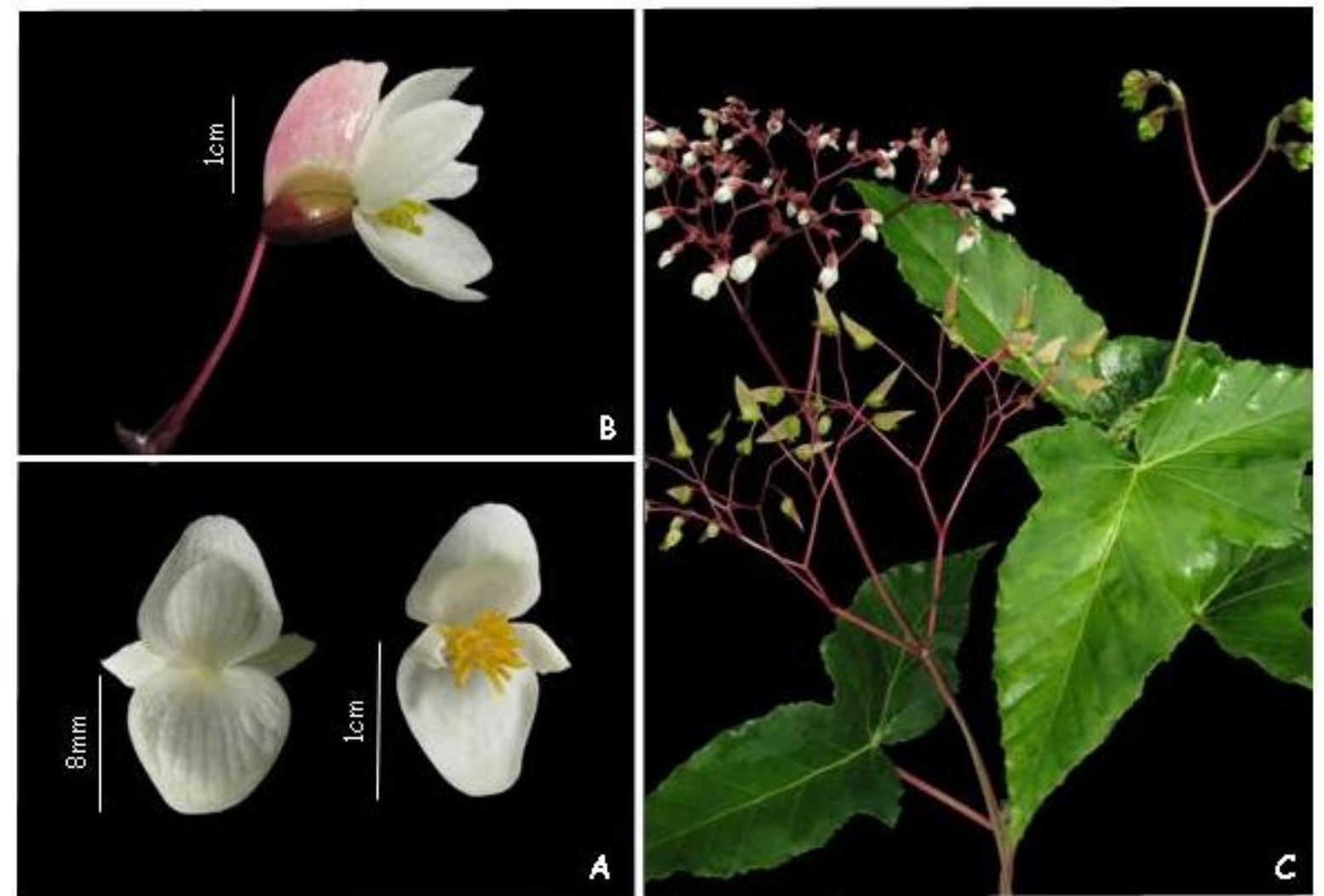

Figura 53: B riedelit A-flores estaminadas, detalhe; B - detalhe da flor pistilada; c- ramo.
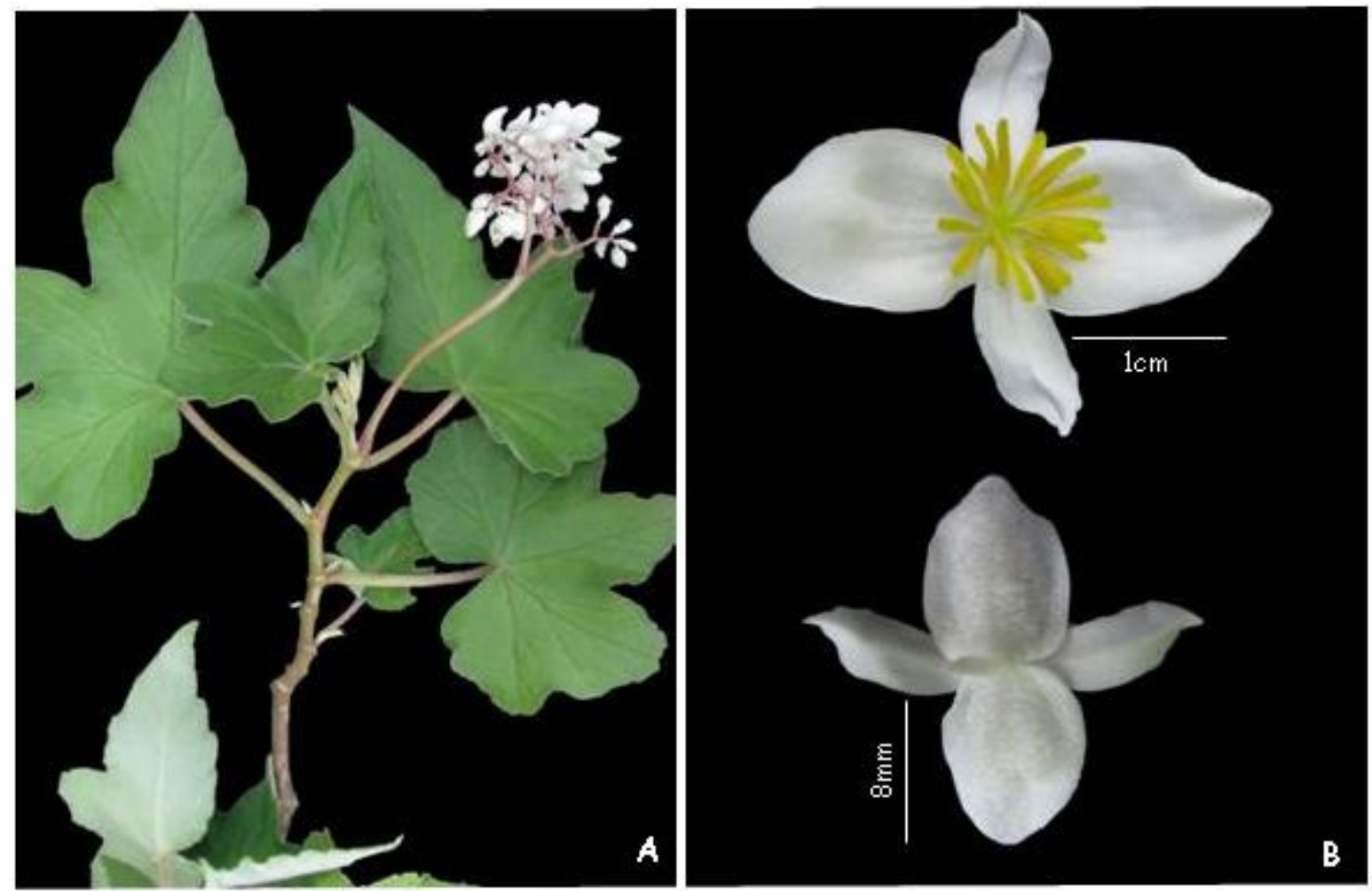

Figura 54: B. rufa. A- ramo: B- detalhe das flores estaminadas. 
4.4.29. Begonia ulmifolia Willd., Sp. pl. 4:418, 1805.

Donaldia ulmifolia (Willd.) Klotzsch, Monatsber. Königl. Preuss. Akad. Wiss. Berlin, :127, 1854, nomen nudum; Abh. Königl. Akad. Wiss. Berlin 1854, :199, 1855; Begoniac., :79, 1855.

Begonia dasycarpa A. DC., Ann. Sci. Nat. Bot. sér. 4, 11:127, 1859.

Begonia jairii Brade, Arch. Jar. Bot. Rio de Janeiro 10:135, pl. 5, 1950, "jairl". Tipo: Brasil: Espírito Santo. Estrada de ferro Vitória-Minas Gerais, entre Boa Vista e Estação Pedro Palácio, Vieira 44 \& Mendonça, IX/1949; Município de Itaguassú, Jatiboca, Brade 18392 et al., V/1946 (Holótipo: RB!, Parátipo: RB!).

(PRANCHA: fig.57: A-E, pág.124; MAPA: fig.55, pág.123)

ERVAS pubescentes a vilosas, tricomas simples, 0,5-1,5m alt. CAULES 0,5-1 cm diâm., eretos, suculentos, estriados a angulosos nas partes adultas, simples, verdes, glabrescentes; entrenós $0,5-1 \mathrm{~cm}$ comp. ESTÍPULAS 1,2-1,6cm comp., 0,3-0,6cm larg., triangulares, ápice mucronulado, base truncada, margem inteira, membranáceas, persistentes, apressas, pubescentes a vilosas, principalmente na nervura mediana dorsal. FOLHAS com peciolos 0,4-1cm comp., cilíndricos a estriados, pubescentes a vilosos; lâminas (6-)6,5-10,5cm comp., 1,8-4(-4,5)cm larg., inteiras, basifixas, papiráceas, elípticas a ovais, assimétricas, ápice acuminado, base assimétrica, margem irregularmente serreada ciliada, vilosas em ambas as faces, indumento mais denso na face abaxial, face adaxial verde, face abaxial verde, rósea ou cinérea, venação caspedódroma. CIMEIRAS 20-50 flores, 3-5 nós; pedúnculos 3-8cm comp., pubescentes a vilosos, tricomas simples; brácteas 1 par, 0,5-09 cm comp., 0,1-0,3cm larg., lanceoladas, ápice mucronulado, base truncada, margem inteira, persistentes, glabras. FLORES ESTAMINADAS tépalas inicialmente 4, posteriormente 2, as externas $0,7-1 \mathrm{~cm}$ comp., $0,5-0,8 \mathrm{~cm}$ larg., ovais, ápice obtuso, base subcordada, margem inteira, vilosas, alvas a esverdeadas, as internas, quando presentes, 0,6-0,9cm comp., 0,2-0,4cm larg., ovais, ápice arredondado, base cuneada, margem inteira, glabras, alvas a esverdeadas; pedicelos 0,3-0,5cm comp., pubescentes a vilosos; bractéolas 1 par, 0,3-0,5cm comp., ca. $1 \mathrm{~mm}$ larg., lanceoladas, ápice mucronulado, base truncada, margem inteira, persistentes, glabras; estames 30-70, ca. $3 \mathrm{~mm}$ comp., filetes livres; anteras aprox. $1 \mathrm{~mm}$ comp., rimosas, oblongas. FLORES PISTILADAS tépalas 5, semelhantes entre si, 0,5-1 cm comp., 0,2-0,4cm larg., elípticas, ápice obtuso, base truncada, margem inteira, glabras, alvas a esverdeadas; pedicelos $0,5-1 \mathrm{~cm}$ comp., pubescentes a vilosos; bractéolas 1-2 pares, 0,3-0,5cm comp., aprox. $1 \mathrm{~mm}$ larg., lanceoladas, ápice mucronulado, base truncada, margem inteira, inseridas tanto no ápice do pedicelo quanto nos nós das cimeiras, persistentes, glabras; estiletes ca. $2 \mathrm{~mm}$ comp.; estigmas ca. $1 \mathrm{~mm}$ comp., ramos cilíndricos e espiralados; hipanto pubescente a viloso. CÁPSULAS 0,5-1cm comp. 0,7$1,4 \mathrm{~cm}$ larg., estiletes persistentes, tépalas e bractéolas caducas, região locular 0,3$0,6 \mathrm{~cm}$ diâm., placentas partidas; alas diferentes entre si, sendo a ala maior levemente ascendente; ala maior 0,5-0,7cm larg., ápice arredondado; alas menores ca. 3mm larg. SEMENTES oblongas. 
DISTRIBUIÇÃO E HÁBITATS: Begonia ulmifolia é uma erva semi-heliófila que ocorre no Vale do Jequitinhonha, Vale do Mucuri e na Zona da Mata mineira, em áreas dominadas pela Mata Atlântica, Cerrado e campos rupestres, habitando interiores e orlas de matas úmidas, afloramentos rochosos exposta ao sol, mas protegida pela vegetação circundante, podendo também viver em associação com outras plantas.

FLORAÇÃO E FRUTIFICAÇÃo: floresce de maio a setembro e frutifica de junho a agosto.

COMENTÁRIOS: Begonia ulmifolia é caracterizada principalmente pelos caules e pecíolos estriados, pelas lâminas elípticas a ovais de base assimétrica e pelas flores estaminadas com duas tépalas. Ainda que na maturidade sempre se verifique duas tépalas nas flores estaminadas de Begonia ulmifolia, no material Delfini, C. 33, \& Paula-Souza, J. (ESA), foi observado algumas flores estaminadas jovens com de quatro tépalas. $O$ mesmo foi observado em dois espécimes de Begonia grisea $A$. DC., no entanto, esta característica é insuficiente e não constante a ponto de permitir o reconhecimento de categorias infra-específicas para esses táxons.

Begonia ulmifolia apresenta similaridades morfológicas com Begonia saxicola A. DC., sendo esta última espécie prontamente distinta pela ausência do indumento, pela margem foliar 1-3 tricomas agrupados entre os dentes e pelas flores estaminadas com quatro tépalas, raramente duas.

MATERIAL EXAMINADO: BRASIL. MINAS GeraIs. Canaã, Cachoeira Grande, 10.VIII.1986, Vieira, M.F. 428, et al. (VIC). Carangola, Fazenda Santa Rita. Cultivada no jardim da sede da fazenda, 24.III.2008, Delfini, C. 33, \& Paula-Souza, J. (ESA); Serra da Gama. Sopé da Pedra de Pato, 1.V.1991, Leoni, L.S. 1546 (SP). Raul Soares, PCH Granada, 5.VI.2002, Mota, R.C. 1632 (BHCB). Salto da Divisa, Fazenda Santana, 19.VIII.2003, Lombardi, J.A. 5286, et al. (BHCB). Theofilo Otoni, A $35 \mathrm{~km}$ de Theófilo Otoni, na bacia hidrográfica do Mucuri, IX.1958, Magalhães, G.M. $14149(H B)$.

MATERIAL ADICIONAL EXAMINADO: BRASIL. EsPírITO SANTO. Boa Vista, Estrada de ferro Vitória-Minas Gerais, entre Boa Vista e Estação Pedro Palácio, VII.1949, Vieira, J. 44 \& Mendonça, J. (RB). Itaguassu, Jatiboca, 23.V.1946, Brade, A.C. 18392 et al. (RB). 
4.4.30. Begonia valdensium A. DC., Ann. Sci. Nat. Bot., IV, 11:138, 1859.

(PRANCHA: fig.57: F-K, pág.124; MAPA: fig.56, pág.123)

ERVAS glabras, até $1 \mathrm{~m}$ alt. CAULES $0,5-1,5 \mathrm{~cm}$ diâm., decumbentes, suculentos, estriados, pouco ramificados, verdes; entrenós $5,5-8,5(-13,5) \mathrm{cm}$ comp. ESTÍPULAS 2,5$4 \mathrm{~cm}$ comp., 0,5-2cm larg., ovais a oblongo-lanceoladas, ápice agudo a mucronado, base truncada, margem inteira a irregularmente ondulada, papiráceas, persistentes, apressas, glabras. FOLHAS com pecíolos 7,5-16,5cm comp., estriados, glabros, somente com um colar de tricomas simples no ápice; lâminas $21-30 \mathrm{~cm}$ comp., $7-15 \mathrm{~cm}$ larg., inteiras a levemente lobadas, basifixas papiráceas, oblíquas a transversais, ovais, assimétricas, ápice agudo a acuminado, lobo basal arredondado, base cordada, margem irregularmente crenulada, glabras em ambas as faces ou as vezes com tricomas muito esparsos na face adaxial, face adaxial verde, face abaxial verde a avermelhada, venação actinódroma, 5-6 nervuras na base. CIMEIRAS 50-200 flores, 4-6 nós; pedúnculos $12-20 \mathrm{~cm}$ comp., glabros; brácteas 1 par, 7-12mm comp., ca. 5-7mm larg., lanceoladas, ápice obtuso, base truncada, margem levemente ondulada, persistentes, glabras. FLORES ESTAMINADAS tépalas 4 , as externas ca. $6 \mathrm{~mm}$ comp., aprox. $5 \mathrm{~mm}$ larg., largamente ovais, ápice obtuso, base cordada, margem levemente ondulada, glabras, as internas 4-5mm comp., ca. $2 \mathrm{~mm}$ larg., ovais, ápice obtuso, base aguda, margem levemente ondulada, glabras, alvas a róseas; pedicelos ca. $1 \mathrm{~mm}$ comp., glabros; bractéolas 1-3 pares, aprox. $1 \mathrm{~cm}$ comp., ca. $0,3 \mathrm{~cm}$ larg., lanceoladas, ápice agudo, base truncada, margem inteira a levemente ondulada, persistentes, glabras; estames 20-25, ca. 3mm comp., filetes livres; anteras ca. $2 \mathrm{~mm}$ comp., rimosas, oblongas. FLORES PISTILADAS tépalas 5, uma delas ligeiramente diferente no tamanho, 4-5mm comp., 2-3mm larg., elípticas a obovais, ápice obtuso a arredondado, base truncada, margem inteira a levemente ondulada, glabras, alvas a róseas; pedicelos aprox. $1 \mathrm{~cm}$ comp., glabrescentes; bractéolas 1-3 pares, 5-7mm comp., 1-2mm larg., lanceoladas, ápice agudo, base truncada, margem levemente ondulada, inseridas no pedicelo, persistentes, glabras; estiletes ca. $3 \mathrm{~mm}$ comp.; estigmas aprox. $2 \mathrm{~mm}$ comp., ramos cilíndricos e espiralados, hipanto glabro. CÁPSULAS ca $1,2 \mathrm{~cm}$ comp., aprox. 2,5cm larg., estiletes persistentes, tépalas e bractéolas caducos, região locular 5-8mm diâm., placentas inteiras; alas diferentes entre si, sendo a ala maior ascendente; ala maior 1,5-1,7cm larg., ápice agudo; alas menores ca. $2 \mathrm{~mm}$ larg. SEMENTES oblongas.

DISTRIBUIÇÃo E HÁBITATS: Begonia valdensium ocorre nas regiões Central e Sul de Minas Gerais, no Vale do Paranaíba e na Zona da Mata, em áreas dominadas por Mata Atlântica e Cerrado, habitando tanto locais iluminados quanto locais sombrios como interiores de matas.

FLORAÇÃO E FRUTIFICAÇÃO: floresce e frutifica no mês de junho.

COMENTÁRIOS: Begonia valdensium apresenta como características únicas entre as espécies do gênero Begonia de Minas Gerais o colar de tricomas no ápice do pecíolo, as estípulas amplas, persistentes e eretas, a ala maior do fruto ascendente e a persistência 
das brácteas e bractéolas. No aspecto geral, Begonia valdensium é bastante semelhante à Begonia longibarbata Brade. Segundo Brade (1948), esta espécie é prontamente diferenciada de Begonia valdensium pela forma do limbo, pelos tricomas esparsos na face adaxial das folhas, pelo colar de tricomas longos no ápice dos pecíolos e pela distribuição restrita à Serra do Itatiaia. Nos poucos materiais analisados de Minas Gerais, observou-se variações significativas principalmente no formato e nas dimensões da lâmina e no tamanho dos tricomas do ápice dos pecíolos, entretanto, tais variações podem estar relacionadas à distribuição e aos hábitats que Begonia valdensium ocupa. Além disso, observou-se sobreposições (ainda que pequenas) nas áreas de distribuição geográfica destas espécies e formas intermediárias não constantes a ponto de permitir o reconhecimento de espécies distintas ou mesmo de categorias infra-específicas para Begonia valdensium. Como foram avaliados somente os espécimes de Minas Gerais e como não foram analisados os materiais tipo de todos os nomes em questão, por estes motivos, optou-se tratar as populações de Begonia longibarbata como sinônimo de Begonia valdensium, embora seja evidente que suas características diagnósticas sejam inconsistentes e que, provavelmente, não são suficientes para sustentá-las como espécies distintas.

Smith et al. (1986) e Golding \& Wasshausen (2002) reconhecem duas variedades para Begonia valdensium: B. valdensium var. valdensium e B. valdensium var. angustior Irmsch., esta última caracterizada pelos pecíolos e pelas folhas menores, no entanto, pelas razões expostas, não foi possivel o reconhecimento de categorias infra-específicas em Begonia valdensium e, além disso, B. valdensium var. angustior é conhecida somente através da coleção-tipo, portanto, de acordo com os critérios estabelecidos pela IUCN (2001), esta variedade seria considerada como provavelmente extinta, por não haver registros de novas coletada nos últimos 30 anos.

MATERIAL EXAMINADO: BRASIL. MINAS GeraIs. Alto Caparaó, Serra do Caparaó, s.d., 1944, Heringer, E.P. s.n. (RB 148864). Bom Jardim, Entre Bom Jardim e Santa Rita, Serra do Pacau, 4.VI.1989, Grandi, T.S.M. s.n., \& Braga, M.M.N. (SP 263345). Delfim Moreira, São Francisco dos Campos, Fazenda São Francisco, 6.VI.1950, Kuhlmann, M. 2390 ( SP, SPF). Ouro Preto, s.d., s.col., s.n. (SP 18022); Caminho do Itacolomi, s.d., s.col., s.n. (RB 47524).

MATERIAL ADICIONAL EXAMINADO (Begonia valdensium var. angustior Irmsch.): BRASIL. SÃo PAULO. Alto da Serra, IV.1912, Luederwaldt, H. s.n. (Síntipo: SP 18004!). Município? s.d., s.col., s.n. (Síntipo: SP 18013!).

MATERIAL ADICIONAL EXAMINADO (Begonia longibarbata): BRASIL. RIO DE JANEIRO. Serra do Itatiaia, caminho para as macieiras, km 10-12, 1400-1700m s.n. do mar. 24.II.1945, Pereira, E. 319 (RB: Holótipo!, Parátipos!, Isótipos!). 


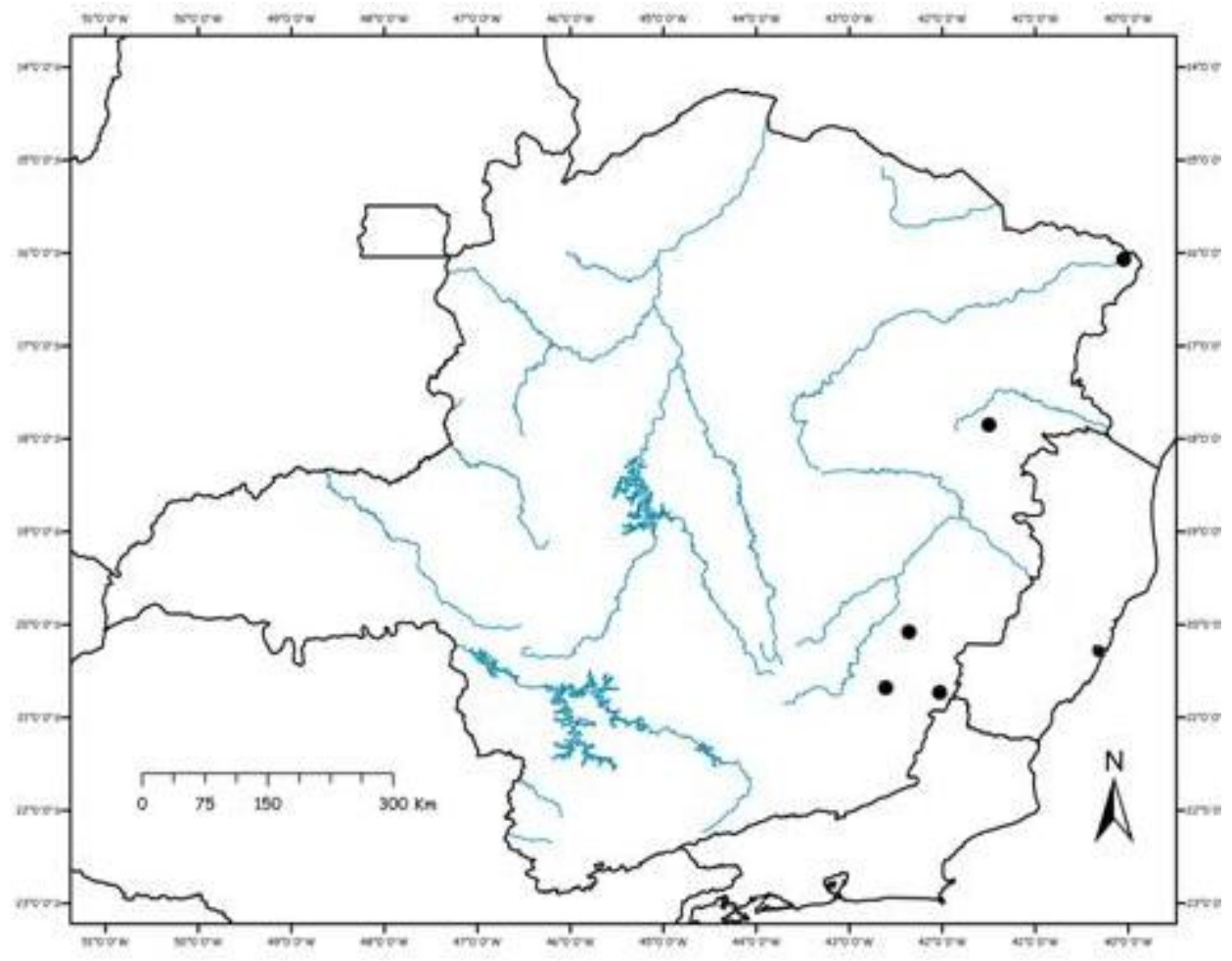

Figura 55: Mapa de distribuição geográfica de B. uhifolio

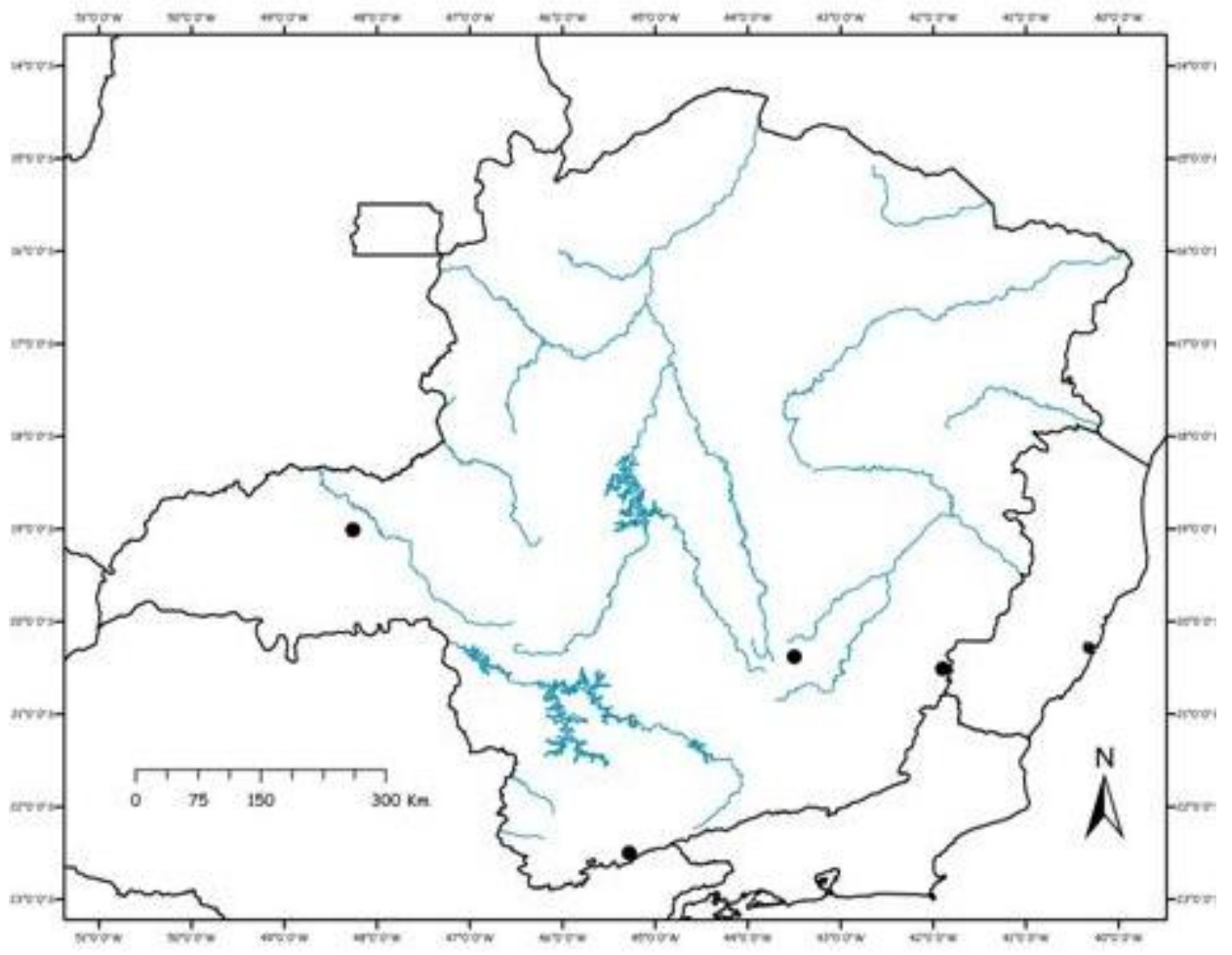

Figura 56: Mapa de distribuição geográfica de B. voldensium 


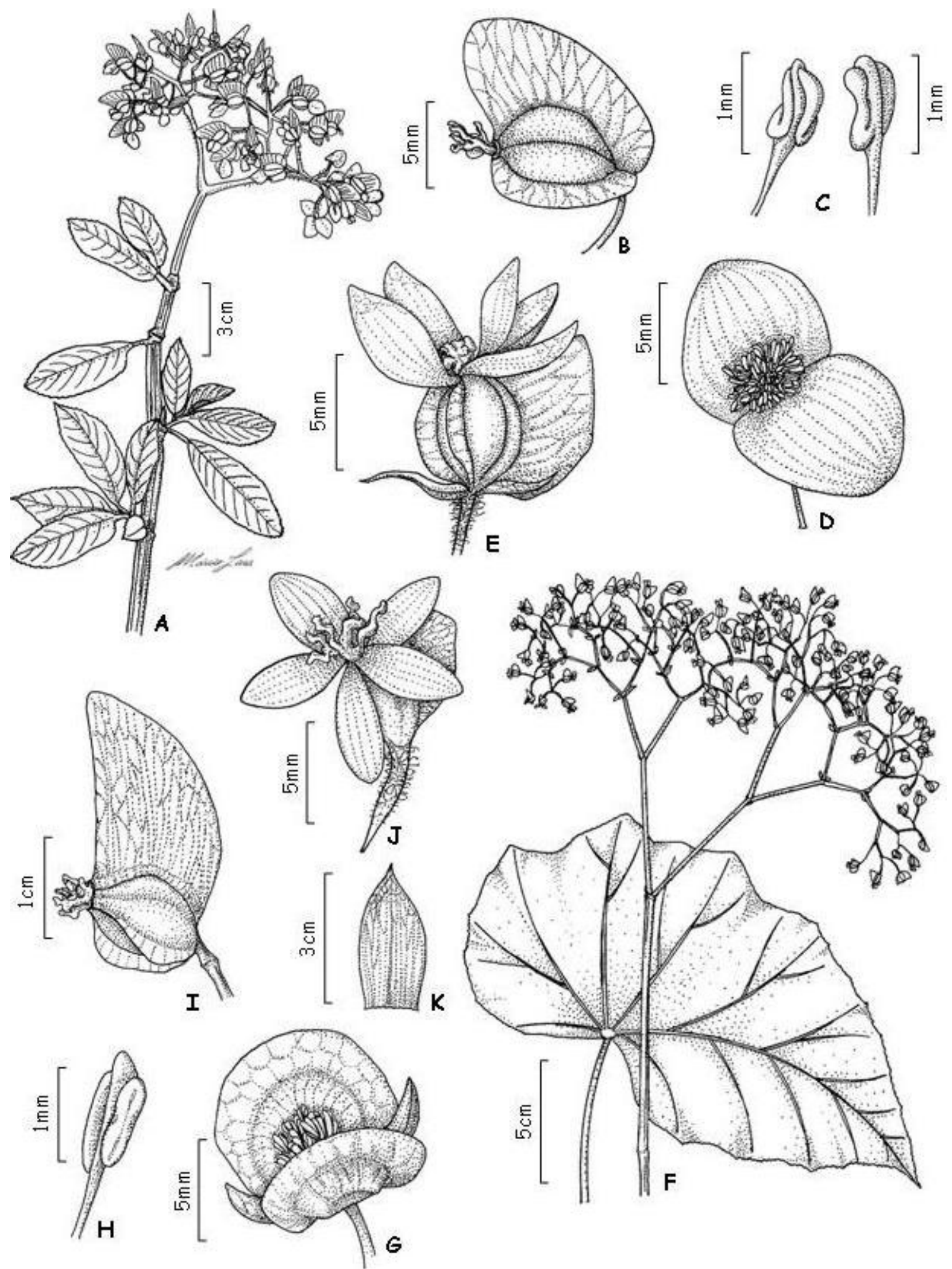

Figura 57: A-E: B. uhmifolia A- hábito; B- cápsula; C- estame; D- flor estaminada; Eestame. F-K: $\boldsymbol{B}$. valdensium F- hábito; G- flor estaminada; H- estame; I- cápsula; J- flor pistilada. [A: C. Delfini, 33 \& J. Paula-Souza (ESA); B: M.F. Vieira, 428 et al. (VIC); C-E: R.C. Mota, 1632 (BHCB). F: M. Kuhlmann, 2390 (SP); G-H: T.S.M. Grandi, s.n. \& M.M.N. Braga (SP 263345); I-K: M. Kuhlmann, 2390 (SP)]. 


\subsubsection{Begonia sp.}

(PRANCHA: fig.59: A-G, pág.127; MAPA: fig.58, pág.126; FOTOS: fig.60: A-D, pág.128)

ERVAS delicadas, glabras, até $40 \mathrm{~cm}$ alt. CAULES subterrâneos, formado por um tubérculo alaranjado, com inúmeras raízes adventícias; entrenós 0,5-3(-5)cm comp. ESTÍPULAS 0,4-0,9cm comp., 0,4-0,6cm larg., triangulares, ápice mucronulado, nem sempre distinto, base truncada, margem irregular, as vezes ciliada, membranáceas, tardiamente caducas, apressas, glabras. FOLHAS com pecíolos 4-9,5cm comp., estriados, glabros; lâminas 4,5-22 cm comp., 4-19cm larg., inteiras, peltada, membranáceas, largamente ovais a orbiculadas, tenuamente lobada, levemente assimétrica, ápice agudo, nem sempre distinto, margem irregularmente denteada, glabras em ambas as faces, face adaxial verde, face abaxial avermelhada, venação actinódroma, 6-9 nervuras no ápice do pecíolo. CIMEIRAS (1-)2-5 flores, 2-3 nós; pedúnculo 15-24cm comp., glabro; brácteas 1 par, 0,9-1,4cm comp., 0,5-1cm larg., triangulares, ápice obtuso, base truncada, margem inteira, persistentes, glabras. FLORES ESTAMINADAS tépalas 4, as externas $1,5-3,3 \mathrm{~cm}$ comp., $2-3 \mathrm{~cm}$ larg., largamente obovais, ápice arredondado, base arredondada, margem inteira, glabras, alvas a róseas; pedicelos 1-2,5cm comp., glabros; bractéolas $1(-2)$ pares, $0,5-1 \mathrm{~cm}$ comp., 0,4-0,9cm larg., triangulares, ápice obtuso, base truncada, margem inteira, persistentes, glabras; estames 50-80, ca. $4 \mathrm{~mm}$ comp., filetes livres; anteras aprox. $1 \mathrm{~mm}$, rimosas, oblongas. FLORES PISTILADAS tépalas 5, uma delas ligeiramente diferente no tamanho e na forma, 2-2,5cm comp., 1-1,5cm larg., ovais a largamente ovais, ápice arredondado, base truncada, margem inteira, glabras, tépalas alavas e hipanto róseo; pedicelos 24,5cm comp., glabros; bractéolas 1-2 pares, 0,5-1cm comp., 0,4-0,9cm larg., triangulares, ápice obtuso, base truncada, margem inteira, inseridas no pedicelo, persistentes, glabras; estiletes ca. $1 \mathrm{~mm}$ comp.; estigmas aprox. $1 \mathrm{~mm}$ comp., ramos cilíndricos e espiralados; hipanto glabro. CÁPSULAS 1-2cm comp., 1-2,3cm larg., tépalas, estiletes e bractéolas caducos, região locular 0,6-0,9cm diâm., placenta partida; alas diferentes entre si; ala maior 0,5-1,5cm larg.; alas menores 0,1-0,3cm larg. SEMENTES oblongas.

DISTRIBUIÇÃO E HÁBITATS: Begonia sp. uma erva umbrófila que ocorre na Zona da Mata mineira, nos domínios da Mata Atlântica, habitando em campos de altitude, paredões rochosos, entre rochas úmidas. Em épocas secas, Begonia sp. perde a parte aérea tornando-se imperceptível entre a vegetação circundante.

FLORAÇÃO E FRUTIFICAÇÃo: floresce de janeiro a março e frutifica no mês de março.

COMENTÁRIOS: Begonia sp. apresenta como características únicas entre as espécies de Minas Gerais as folhas peltadas, as estípulas com margem irregular, as cimeiras paucifloras (1-)2-5 flores, as brácteas e bractéolas (de ambas as flores) grandes e as anteras obovais. Esta espécie possui similaridades morfológicas com Begonia paulensis $A$. DC., sendo prontamente distinta pelas características apresentadas na tabela $X$, pág.99. Em virtude da homogeneidade dos materiais examinados, das características bem definidas não encontradas em outro táxon, nem em bibliografias, Begonia sp. é um novo 
registro de Begonia para a flora de Minas Gerais e, muito provavelmente, uma novidade para a ciência.

Material eXaminado: BRASIL. Minas GeraIs. Alto Caparaó, Parque Nacional do Caparaó. Cachoeira Bonita, sob escarpa rochosa, em local bastante úmido, 25.III.2008, Delfini, C. 35, \& Paula-Souza, J. (ESA); Parque Nacional do Caparaó. Cachoeira Bonita, segue ao lado do Córrego crescendo sob formações rochosas, 10.I.2001, Leoni, L.S. 4568, Dutilh, J. et al. (GFJP);

MATERIAL ADICIONAL EXAMINADO: BRASIL. Espírito SANTO. Iúna, Parque Nacional do Caparaó. Entre o terreirão e o arrozal. Campo de altitude, s.d., Souza, V.C. 23381, et al. (ESA).

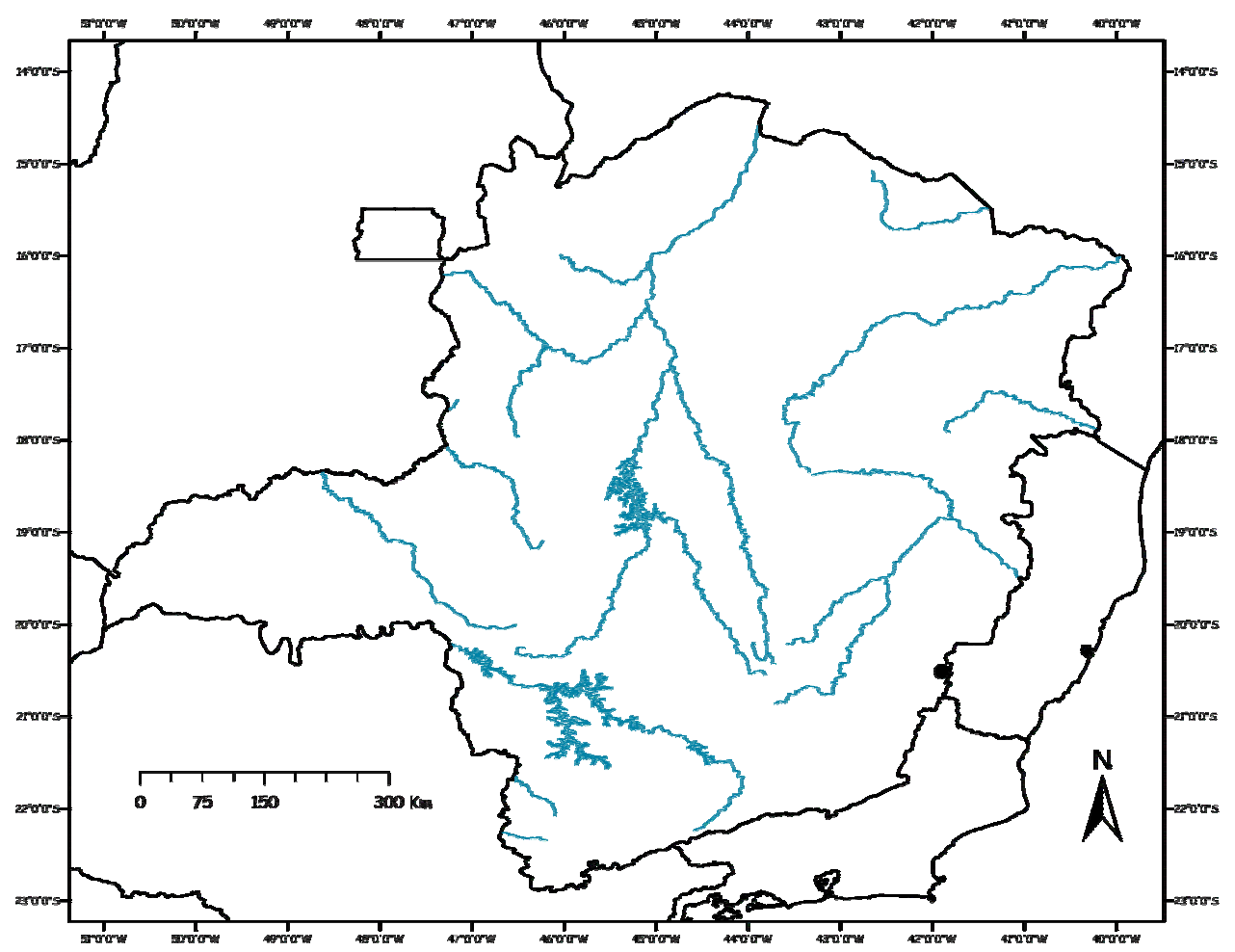

Figura 58: Mapa de distribuição de Begonia sp. 


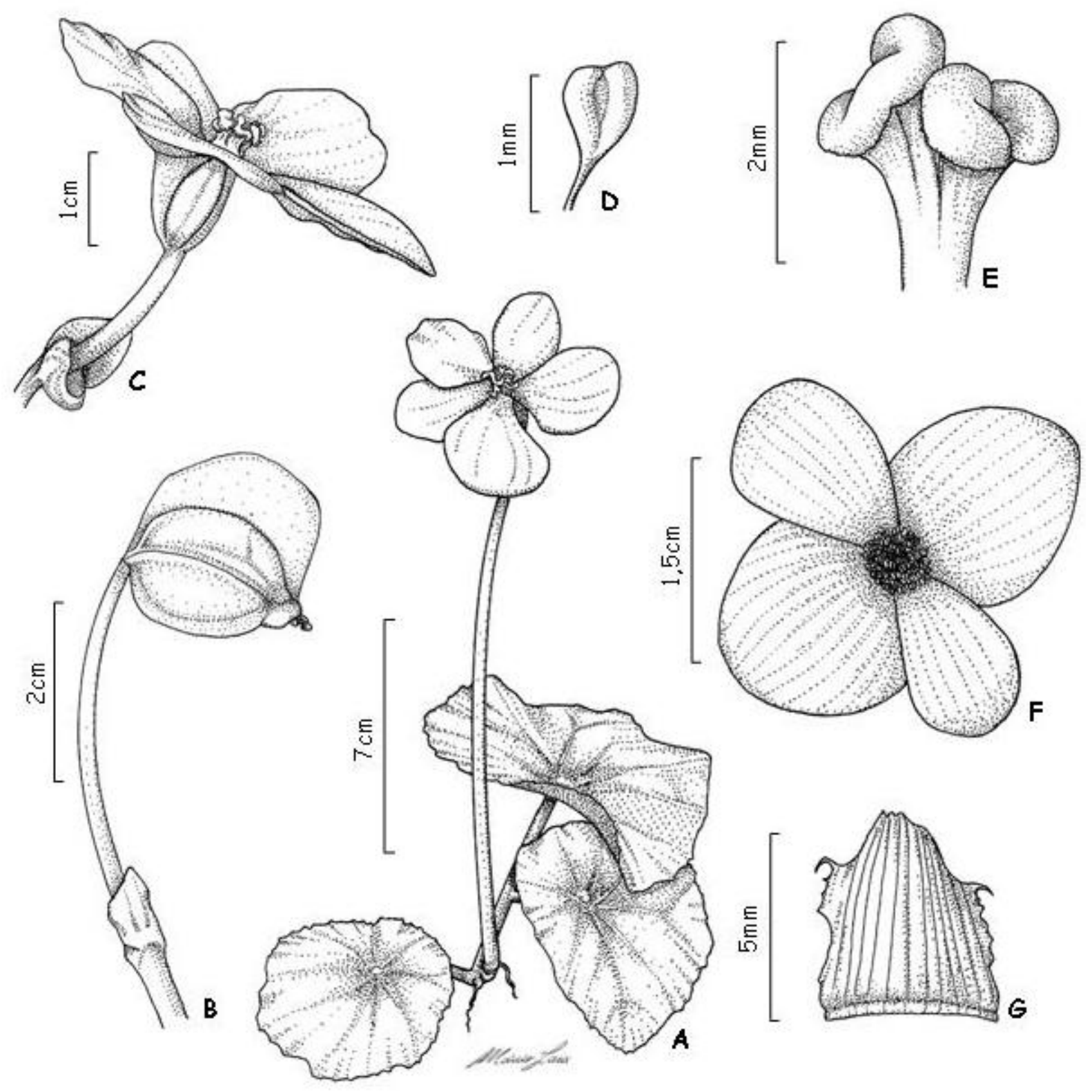

Figura 59: A-G: Begonia sp.: A- hábito; B- cápsula; C- flor pistilada; D- estame; Eestigma; F- flor estaminada; G-estípula. [A-C: $C$. Delfini 35 \& J. Paula-Souza (ESA); D: V.C. Souza, 23381 et al (ESA); E: C. Delfini 35 \& J. Paula-Souza (ESA); F: V.C. Souza, 23381 et a) (ESA); G: C. Delfini 35 \& J. Paula-Souza (ESA)]. 

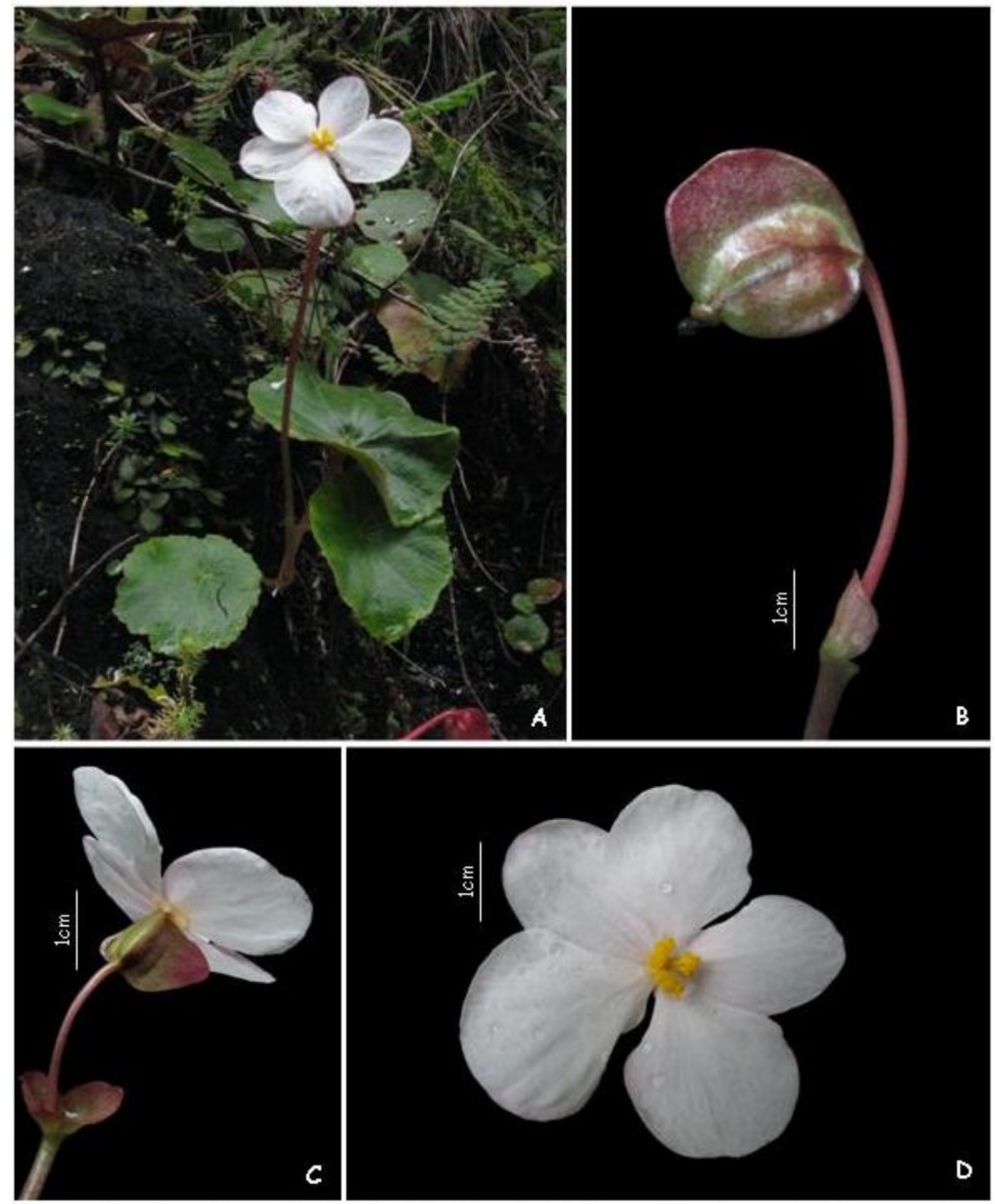

Figura 60: Begoniosp: A- hábito; B- detalhe do fruto: $C$ - detalhe do hipanto e das brácteas; $\mathbf{D}$ - detalhe das tépalas e dos estigmas. 


\section{CONSIDERAÇÕES FINAIS}

Para o Estado de Minas Gerais, são reconhecidas 31 espécies do gênero Begonia;

$\checkmark$ Das 31 espécies encontradas:

- 27 espécies são brasileiras;

- 4 espécies são endêmicas;

- 3 espécies são novos registros de Begonia para a flora de Minas Gerais, sendo duas novas espécies para a ciência.

$\checkmark$ A maioria das espécies do gênero Begonia do Estado de Minas Gerais é encontrada em áreas dominadas pela Mata Atlântica e pelo Cerrado, habitando preferencialmente locais úmidos e sombreados, tais como interiores de matas, próximas às margens de rios e córregos. Cerca de um terço das espécies cresce em áreas de afloramentos rochosos (campos rupestres) e um pequeno grupo de espécies pode ser encontrado em áreas alteradas ou nos domínios da Caatinga, ainda que exijam ambientes úmidos (abaixo, mapa de distribuição do gênero Begonia em Minas Gerais):

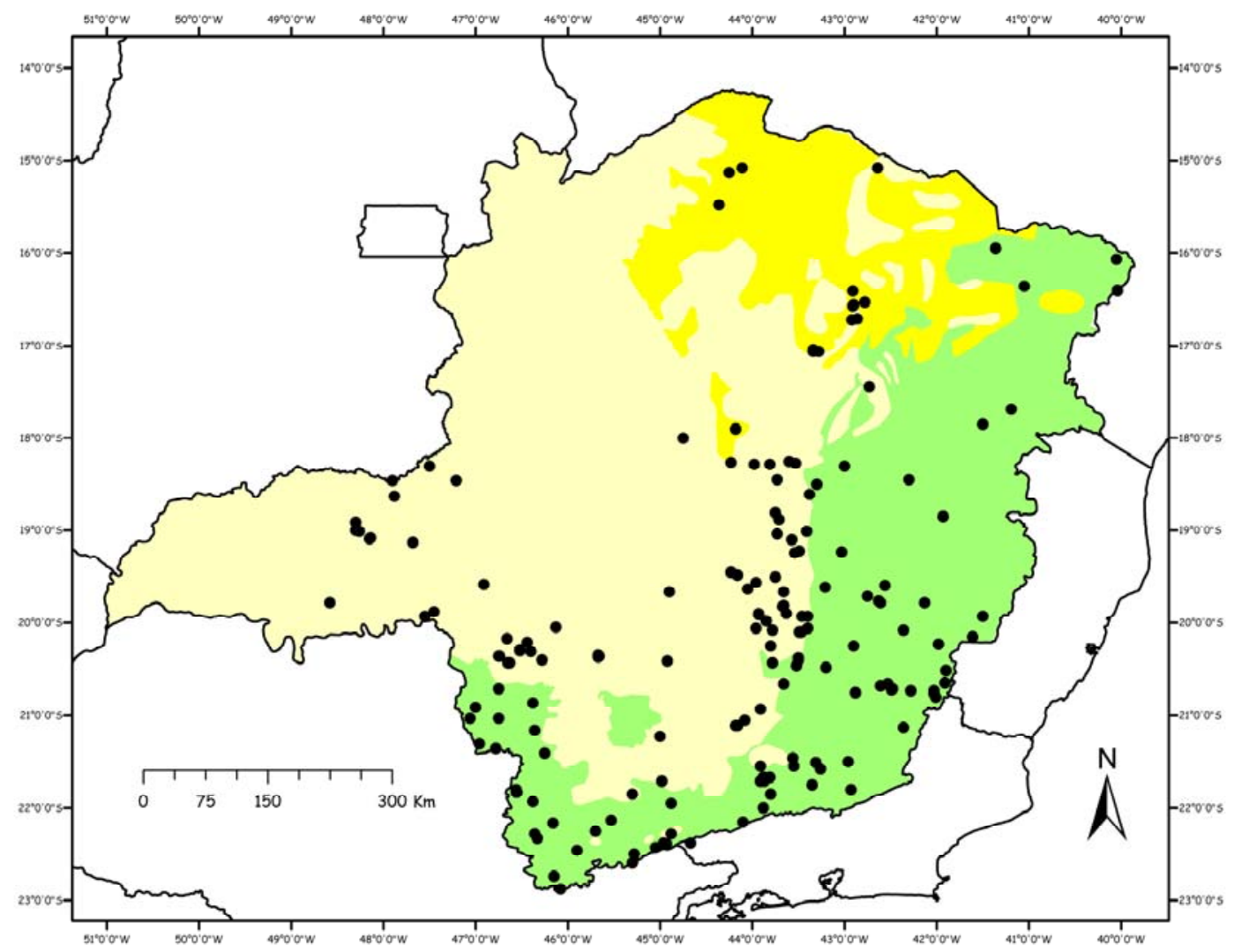

Figura 61: Mapa de distribuição do gênero Begonia em Minas Gerais, adaptado de GeoMINAS (2009).

$\checkmark O$ estudo taxonômico detectou uma grande variação morfológica nos espécimes coletados em Minas Gerais, o que foi relacionado à distribuição e aos hábitats de ocupação ou à plasticidade fenotípica das populações estudadas. Para algumas espécies são reconhecidos táxons infra-específicos, no entanto, como os extremos de variação 
foram muito discrepantes, verificou-se uma grande dificuldade (ou mesmo impossibilidade) em se identificar os materiais ao nível de variedades. Como foram avaliados somente os espécimes de Minas Gerais e como também não foram analisados os tipos de todos os nomes em questão, não foi possível concluir a respeito de sinonimizações, tanto quanto estabelecer um padrão dentro de toda a plasticidade morfológica encontrada que permitisse a correta identificação neste nível, embora seja evidente que tais características diagnósticas sejam inconsistentes e, provavelmente, não suficientes para o reconhecimento de variedades distintas;

$\checkmark$ A maioria das espécies do gênero Begonia de Minas Gerais é reconhecida por um conjunto de características, no entanto, em alguns casos é possível delimitar um pequeno grupo de espécies apenas pela forma das folhas ou associado a uma informação complementar:

$\checkmark$ A forma da lâmina e o tipo de indumento mostraram-se muito variáveis, entretanto, foram determinantes na identificação e na delimitação das espécies;

$\checkmark \mathrm{Na}$ grande maioria das espécies, a persistência e caducidade das estípulas são bem definidas, sendo, portanto, uma boa característica para a separação de espécies;

$\checkmark$ número de tépalas das flores estaminadas de Begonia grisea e Begonia ulmifolia pode variar nas flores jovens:

$\checkmark O$ número reduzido de materiais, em alguns casos, que as espécies em questão estão subamostradas em termos de coleta. 


\section{LISTA DE EXSICATAS}

\section{Legenda:}

(alc): B. alchemilloides

(alt): B. altamiroi

(ang): $B$. angularis

(agt): B. angulata

(app): B. apparicioi

(con): B. convolvulacea

(cuc): B. cucullata

(cur): B. curtii

(dig): B. digitata

(fis): B. fischeri

(fru): B. fruticosa (gar): B. gardneri

(gri): B. grisea

(her): $B$. heringeri

(hir): B. hirtella

(hug): B. hugelii

(inc): $B$. incisoserrata

(int): $B$. integerrima

(lux): B. luxurians

(mac): B. maculata

(moy): B. moysesii

(neo): B. neocomensium (nud): Begonia aff. nuda

(pau): B. paulensis

(ren): B. reniformis

(rie): B. riedelii

(ruf): B. rufa

(ulm): B. ulmifolia

(val): B. valdensium

(sp): Begonia sp.

Total: 582 exsicatas
Alli, J.R.S. s.n.: (fis) BHCB 14410

Alves, R.J.V. 149: (hir); 310: (ruf)

Alvim, P. s.n.: (lux) VIC 3442

Andt, M.A.L. \& Aristóbolo, M.S. s.n.: (ruf) SP 263349

Andrade, P.M. \& Drumond, M.A. 1127:

(ang)

Andrade, P.M. \& Hilde, R. 847: (ruf)

Andrade, P.M. \& Lopes, M.A. 699: (gar)

Andrade, P.M. et al. 795: (ruf); 831: (lux)

Andrade, P.M. 1396: (ang)

Arantes, A.A. \& Ranal, M. 1372: (fis)

Araújo, G.M. \& Barbosa, R.A. s.n.: (cuc)

HUFU 19594

Araújo, S. \& Alt. Barb. 140: (ruf), 194: (dig)

Arbo, M.M. et al. 4017: (agt); 4081: (alc); 4252: (ruf); 4369: (gri)

Atui, J.P. et al. 6: (gri)

Azevedo, A.M.G. 8576: (fis)

Barbosa, A.A.\& Amaral, A.F. 1320: (cuc)

Barbosa, A.A. 3554: (cuc)

Barbosa, A.A.A. s.n.: (hir) ESA 102862

Barreto, M. \& Brade, A.C. 1062: (ruf)

Barreto, M. \& Viegas, A.P. s.n.: (ruf) SP 48966

Barreto, M. 1832: (ruf); 1837: (ruf); 1843: (cuc); 1846: (fis); 4036: (fis)

Barroso \& Ferreira 8: (agt); 21: (ruf); 84: (ruf)

Bastos, E. 660: (lux)

Bautista, H.P. 559: (cuc)

Black 2131b: (alc); 2542b: (alc); 51b: (hir)
Black, G. 2131: (alc); 2131b: (alc)

Boechat, S. 7: (con)

Borges, R.A.X. \& Bernardo, P.H. 146:

(ren); 183: (ren); 208: (ren)

Brade, A.C. \& Altamiro 18017: (ren)

Brade, A.C. \& Araújo, S. 18928: (fis);

18935: (pau); 18949: (agt); 18954: (ruf);

19072: (agt)

Brade, A.C. \& Barbosa, A. 17578: (fis)

Brade, A.C. et al. 18387: (app); 18392:

(ulm) RB; 18400: (alt) RB

Brade, A.C. 14556: (pau); 16448: (fru); 19783: (cur) RB; s.n.: (dig) RB 148865

Braga, M.M.N. \& Grandi, T.S.M. s.n.: (fis)

BHCB 17552

Braga, P.I.S. 2426: (ang)

Brandão, M. \& Araújo, M. 22066: (ang); 22066: (ang)

Brandão, M. 12911: (app); 13073: (hir); 14523: (cuc); 14983: (cuc); 15733: (fis); 16706: (hir); 18428: (gri); 18995: (gri); 19426: (cuc); 19541: (fis); 20799: (con); 20910: (fis); 22057: (cuc); 22215: (gri); 24159: (app); 24365: (ang); 24369: (app); 24369: (ruf); 24404: (ang); 24844: (ang); 24845: (ang); 24928: (ang); 24940: (ang); 25479: (ruf); 27098: (ang); 27868: (ang); 27870: (cuc); 28937: (app); 28974: (ang); 29271: (ren); 29272: (fis)

Brina, A.E. s.n.: (cuc) BHCB 39549

Buendia, L. 487: (fis)

Bufo, L.V.B. et al. 181: (con)

Calió, M.F.A. et al. 20: (gri) 
Campos, M.T.V.A. et al. s.n.: (ren) ESA 102863

Carcerelli, C. 5: (fis)

Carvalho, A.F. 184: (cuc); 647: (cuc); 745:

(ang)

Coelho, L.B.V. 82: (cuc)

Coons, M.P. et al. 77-1227: (ren)

Cordeiro, I. \& Romaniuc Neto, S. 596: (ruf)

Cordeiro, I. et al. s.n.: (alt) SPF 35511

Cordeiro, I. 1657: (con)

Costa, J.M. s.n.: (ruf) VIC 5194

Cunha, L.H.S. 352: (cuc); 1001: (cuc); 1002: (fis)

Damazio, L. 1697: (ang)

Davis, P. et al. 2280: (gri); 2407: (gri)

Delfini, C. \& Paula-Souza, J. 33: (ulm); 34:

(hug); 35: (sp); 36: (dig); 37: (con); 38: (int); 39: (rie); 40: (fis); 41: (ang); 42: (app); 43: (ang); 44: (fru); 45: (lux); 46: (fis); 47: (cuc); 48: (cur); 49: (ang); 50: (inc); 51: (ruf); 52: (ang)

Delfini, C. \& Romão, G.O. 22: (cuc); 28: (ang); 29: (cuc); 30: (ruf); 31: (ruf)

Delfini, C. \& Tsuji, R. 53: (agt); 54: (fis); 55: (ang); 60: (alt)

Duarte, A.P. 495: (ruf); 556: (fis); 2744: (ruf); 3080: (hug); 3081: (lux); 3082: (gar); 3793: (ruf); 3794: (ang); 7577: (ruf); 8547: (gri); 12767: (ang)

Edwall, G. CGG5765: (int) SP

Elcione et al. s.n.: (ruf) SPF 148103; s.n.: (ruf) ESA 80589

Esteves, G.L. et al. s.n.: (ruf) RB 273547

Farinaccio, M.A. et al. 344a: (ruf); 344b:

(app)

Farney, C. 217: (alc)

Ferrari, J.M. 633: (mac)

Ferreira \& Cunha 8842: (app); 7842: (ruf)

Ferreira et al. 5248: (ruf)

Ferreira, M.B. 5498: (hir); 5516: (ruf); 5614: (ruf)

Fontella 1078: (ruf)

Forzza, R.C. \& Marcato, A.C. 355: (gri)

Forzza, R.C. et al. 2111: (agt); 3109: (agt); 3129: (ang); 3151: (lux); 3320: (ang); 3330: (ruf); 3333: (ang)

França, G.S. et al. 566: (cuc)

Freitas, V.O. et al. s.n.: (cuc) HXBH 14426; s.n.: (cuc) HXBH 14407
Galvilanes, M.L. \& Frieiro, F.N.C. 4847: (ang)

Garcia, M.V.B. s.n.: (cuc) VIC 8673

Gentry, A. et al. 59099: (ren); 59144:

(fis)

Giordiano, L.C. et al. 2472: (ang)

Giulietti, A.M. et al. S.n.: (ruf) SPF 20159

Godoy, S.A.P. et al. s.n.: (ruf) SPF 44892

Gonçalves. L.O.O. \& Donato, P.E.R. S.n.: (cuc) VIC 7835

Grandi, T.S.M. \& Andrade, P.M. 1945: (ruf)

Grandi, T.S.M. \& Braga, M.M.N. 328:

(ang); s.n.: (val) SP 263345

Grandi, T.S.M. et al. 2617: (lux)

Grandi, T.S.M. 103: (mac); 881: (ruf)

Handro, O. 290: (app)

Harley, R.M. et al. 25131: (gri); 25158: (nud); 25243: (gri); s.n.: (gri) SPF 36110

Hashimoto, G. 503: (agt)

Hatschbach, G. \& Barbosa, E. 79362: (gri)

Hatschbach, G. \& Pelanda, P. 27890: (gri)

Hatschbach, G. \& Silva, J.M. 52225: (ren)

Hatschbach, G. et al. 36564: (alt);

36564: (alt); 36564: (ruf); 54155: (gri);

55539: (ang); 55544: (ren); 73476: (gri)

Hatschbach, G. 27304: (gri); 30073:

(ruf); 41563: (gri); 46298: (pla); 46298:

(pla); 57140: (gar)

Hensold, N. et al. s.n.: (ruf) SPF 22411

Heringer, E.P. 1530: (fru); 1566: (mac); 1605: (con); 1606: (con); 1621: (fis); 1622: (hug); 1637: (cuc); 1647: (cuc); 1657: (fis); 1660: (fru); 1725: (fis); 1727: (cuc); 1737: (her) RB; 1885: (ren); 1935: (dig); 1937: (hug); 2523: (ang); 2682: (ruf); 1737a: (her); 1737b: (her); 1737c: (her); 2541-54: (con); s.n.: (alc) HB 13800; s.n.: (lux) VIC 12751; s.n.: (lux) VIC 12995; s.n.: (ruf) MBM 22818; s.n.: (val) RB 148864

Hoehne, F.C. s.n.: (ren) SP 19495; s.n.: (ruf)

Irwin, H.S. 2183: (cuc)

Joly, A.B. et al. 2169: (ruf); s.n.: (ruf) UEC 512

Kameyama, C. et al. s.n.: (gri) SPF 41072

Kameyama, V.L. et al. s.n.: (ruf) SPF 71876

Karam, C.M. 22: (fis) 
Kawasaki, M.L. et al. s.n.: (gri) BHCB 59664; s.n.: (gri) SPF 36223; s.n.: (ren) SPF 20385

Kinoshita, L.S. \& Matsumoto, K. 531: (cuc) Kinoshita, L.S. et al. 86: (cuc) Krieger, L. \& Sabino, M. 16236: (ang) Krieger, L. et al. 77-1012: (ruf), 77-1226: (ren); 77-294: (alt); 77-295: (agt) Krieger, L. 14620: (agt); 15121: (con); 16237: (ruf); 21420: (app); 21420: (ruf) Kuhlmann s.n.: (cuc) VIC 2432; s.n.: (hir) VIC 2433; s.n.: (lux) VIC 2434

Kuhlmann, J.G. s.n.: (lux) RB 136901 Kuhlmann, M. \& Gehrt, A. s.n.: (app) RB 57284

Kuhlmann, M. 2390: (val); 2401: (moy) SP Leitão Filho, H.F. et al. 2027: (ren); 9503: (ruf); 17333: (gri); 19343: (ruf); 20904: (fis); 27621: (ang); 27621: (ang) Leoni, L.S. et al. 4568: (sp); 4582: (pla) Leoni, L.S. 1472: (pla); 1546: (ulm); 1572: (lux); 1669: (con); 1746: (agt); 2563: (alt); 2567: (cuc); 2569: (hug); 2585: (ang); 2633: (int); 3276: (ang); 3416: (int); 3416: (int); 4332: (cur); 4496: (con) Lima, H.C. et al. 1331: (ruf); 1343: (ruf)

Lima, L.R. et al. 201: (cuc)

Lisboa, M.L.G. \& Silveira, R.G.S. s.n.: (lux) VIC 14429

Lobato, P. et al. 1720: (hir)

Lombardi, J.A. et al. 1598: (ruf); 1598: (ruf); 1598: (ruf); 5286: (ulm); 5440: (fru); 5553: (ang); 5572: (ang)

Lombardi, J.A. 610: (gar); 1866: (ruf); 1946: (app); 2277: (ruf); 2420: (con); 2420: (con); 3077: (lux); 3098: (alt); 3119: (rie); 3121: (hug); 4381: (ruf) Lopes, M.A. \& Andrade, P.M. 326: (con) Luederwaldt, H. s.n.: (fis) SP ; s.n.: (fis) SP; s.n.: (val) SP 18004

Macedo, J.F. 1036: (fis); 2988: (cuc); 3460: (fis); 3942: (cuc)

Maciel, P.L. et al. s.n.: (hir) SP 263351

Magalhães, G.M. 14149: (ulm)

Magalhães, M. 395: (lux); 2125: (gri); 2882: (gar); 2883: (gar); 3345: (alc) Maguire, B. et al. s.n.: (gri) RB 126287 Mansano, V.F. et al. 182: (agt)

Mantone, L. et al. 690: (ruf); 703: (ruf); 779: (ruf); 795: (ruf)
Marcondes-Ferreira, W. \& Tsuji, R. 1738:

(cuc)

Markgraf et al. 3483: (gri)

Marquete, R. et al. 3097: (ruf); 3213: (ruf)

Martinelli, G. 2635: (ruf); 4746: (ruf)

Mattos, J. \& Bicalho, H. 10318: (ang)

Mazine, F.F. \& Forster, W. 163: (dig)

Mazine, F.F. et al. 402: (alc)

Medeiros, E. et al. 305: (ruf)

Meira Neto, J.A.A. \& Silva, A.F. 904: (lux)

Meireles. L.D. \& Belinello, R. 834: (agt); 835: (agt)

Meireles. L.D. \& Nunes, J.A. 2199: (app); 2200: (app); 3072: (pau)

Meireles. L.D. et al. 6: (agt); 918: (cuc); 1014: (agt); 1015: (agt); 1056: (cuc); 1204: (fru); 1890: (app)

Mello-Silva, R. et al. 1345: (ruf); s.n.: (gri) SPF 43851; s.n.: (gri) SPF 44724

Menezes, N.L. \& Meguro, M. s.n.: (gri) SPF 43031

Menezes, N.L. et al. s.n.: (ruf) SPF 133678

Mexia, Y. 4980: (con); 5148: (hug); 5190: (cuc)

Meyer et al. s.n.: (hir) HXBH 11115; s.n.: (fis) HXBH 14383

Meyer, S.T. s.n.: (cuc) HXBH 3329

Moreira, J.L.A. \& Belinello, R. 420: (ruf)

Mota, R.C. et al. 1623: (fru); 2893: (ang)

Mota, R.C. 1401: (cuc); 1632: (ulm); 1635:

(ruf); 2648: (hir); 2959: (fis)

Motta, J.T. 1488: (cuc)

Moura, L.S. \& Vieira, M.F. 401: (ruf)

Nakajima, J.N. et al. 242: (cuc); 933: (alc); 1459: (cuc); 2429: (ang); 2800: (hir) Nic Lughadha, E.M. et al. 235: (ang)

Novelino, R.F. et al. s.n.: (ruf) MBM 279105

Nunes, Y.R.F. et al. s.n.: (ren) HXBH 12015; s.n.: (ruf) SPF 116462

Oliveira, G.C. 152: (cuc); 270: (cuc); 379: (cuc); 418: (cuc); 1056: (cuc); 2523: (cuc) Oliveira, J.E. 305: (hir); s.n.: (ruf) BHCB 41616

Pacheco, R.A. et al. 517: (alc); 568: (app); 601: (alc)

Paciornik, E.F. 214: (ang); 214: (ang) 
Paiva, J.A. 2: (hir)

Paula, C.C. 2005: (ruf)

Paula, J.A. 2: (hir)

Pedrali et al. s.n.: (hug) HXBH 10146; s.n.: (ruf) HXBH 13323

Pedralli \& Meyer s.n.: (cuc) HXBH 8056; s.n.: (ruf) HXBH 10146

Pereira, E 360: (agt) RB; 1504: (cuc); 1506: (fis); 2341: (fis); 2661: (ruf); 3013: (ruf)

Pereira, M. \& Lucca, M. 806: (ruf)

Perez, J.M.A s.n.: (ren) ESA 3761

Pio 190: (cuc); 358: (ren)

Pirani, J.R. \& Yano, O. 708: (ruf); 708: (ruf)

Pirani, J.R. et al. 2549: (ren); 3754: (gar); 4136: (ruf); 4331: (gri); s.n.: (gri) SPF 39823; s.n.: (gri) SPF 69613; s.n.: (ruf) SPF 61861; s.n.: (ruf) SPF 77807

Porto, P.C. 3350: (agt) RB

Ranal, M. 712: (cuc), 754: (cuc)

Rapini, A. \& Kawasaki, M.L. 736: (gri)

Rapini, A. et al. 300: (ruf); 300: (ruf); 683: (ruf)

Regnell, A. I-390: (inc)

Ribas, O.S. 1324: (ang); 1419: (ang)

Rocha, L.B. 6: (fis)

Romão, G.O. et al. 944: (gri)

Romero, R. \& Nakajima, J.N. 3534: (app)

Romero, R. \& Nakajima, J.N. 3534: (app)

Romero, R. et al. 1289: (ruf); 2051: (ang);

2278: (app); 2278: (app); 2437: (ruf);

3937: (ang); 6280: (alc); 6901: (alc); 7007: (alc)

Romero, R. 6222a: (alc)

Roque, N. et al. s.n.: (gri) ESA 23496; s.n.: (gri) SPF 97042

Saint-Hilaire, A. 100: (lux); s.n.: (ang) HB 51720

Sajo, M.G. \& Castro, N.M. s.n.: (ruf) SPF 20405; s.n.: (ruf) MBM 85569

Salimensa-Pires, F.R. et al. s.n.: (ruf) ESA 82631

Salino, A. \& Stehmann, J.R. 3363: (ren)

Salino, A. 3092: (hir)

Sampaio, A.J. 426: (fis)

Sampaio, J.J. s.n.: (pau)

Sano, P.T. et al. 529: (ruf); 976: (ruf)

Santos, H.G.P. et al. 312: (neo)
Schepherd, G.J. et al. 5767: (dig); 7155:

(alc)

Schwacke s.n.: (ruf) RB 47527

Semir, J. \& Stubblebine, W.H. 1944: (cuc)

Semir, J. et al. 28827: (ruf)

Shepherd, G.J. et al. 5767: (dig)

Silva, J.B. 363: (fis)

Simão-Bianchini, R. \& Bianchini, S. s.n.: (ruf) SPF 80316

Simão-Bianchini, R. et al. 489: (fru)

Simões, A.O. et al. 599: (cuc); 794: (ang)

Souza, A.B. \& Márcia 103: (con); 104:

(hug); 105: (con); 106: (ang); 107: (dig)

Souza, V.C. \& Sakuragui, C.M. 2069: (ruf)

Souza, V.C. et al. 8364: (gri); 8364: (gri); 12016: (gri); 12109: (con); 12120: (ren); 12141: (ang); 23180: (ren); 23381: (sp); 25086: (ruf); 25556: (gri); 25778: (gri); 28073: (ruf); 28278: (gri); 28604: (ruf); 32643: (ruf); s.n.: (gri) SPF 40884

Sposito \& Versieux, L.M. 113: (ang)

Stehmann, J.R. et al. 2794: (gri); s.n.: (ruf) SP 335785; s.n.: (ruf) SP 263353

Stubblebine, W.H. 510: (cuc)

Sucre, D. \& Krieger, L. 6783: (agt); 6783: (ruf); 6869: (ang)

Sucre, D. et al. 10117: (con)

Teixeira, W.A. s.n.: (alc) SP 277267; s.n.: (cuc) SP 277268; s.n.: (cuc) BHCB 26506; s.n.: (hir) BHCB 26295; s.n.: (ruf) BHCB 25049

Temponi, L.G. et al. 144: (con); 393: (agt)

Temponi, L.G. 1: (ruf)

Trovó, M.L.O. et al. 173: (ruf)

Vasconcellos, S. S.n.: (ruf) SP 18035

Vasconcelos, M.F. 40307: (ang); s.n.: (ang) SP 335791

Veríssimo, P. 542: (fis); 634: (cuc); 683:

(cuc); 1053: (cuc)

Viana, P.L. 649: (ruf)

Vidal, W.N. et al. 592: (lux)

Vieira, J. Mendonça, J. 44: (ulm) RB

Vieira, M.F. \& Soares, M.F. 740: (fis); 741: (cuc); 756: (fis)

Vieira, M.F. et al. 428: (ulm); 453: (con); 476: (hug); 478: (lux)

Vitta, F.A. \& Souza, V.C. s.n.: (cuc) SPF 67794

Volpi, R.L. et al. 146: (app); 146: (app) 
Wagner, H.L. et al. s.n.: (gri) SPF 41668 Wanderley, M.G.L. et al. 2080: (ruf)

Werneck s.n.: (cuc) HXBH 11734

Williams, L.B. 7273: (alc)

Williams, L.O. \& Assis, V. 6346: (ruf); 6706: (ang); 6746: (alc); 7273: (alc); 7301: (ren)

Xavier, A. s.n.: (cuc) VIC 9459
Zappi, D.C. \& Kameyama, C. s.n.: (ren) SPF 47797

Zappi, D.C. et al. S.n.: (ruf) SPF 46860; s.n.: (ruf) MBM 254475; s.n.: (ruf) SPF 65687; s.n.: (ruf) SPF 63879; s.n.: (ruf) SPF 40384

Coletor? s.n.: (val) SP 18022; s.n.: (val) RB 47524; s.n.: (val) SP 18013; s.n.: (ruf) RB 47526; s.n.: (ang) SP 342701 


\section{LISTA DE NOMES CIENTÍFICOS}

(Citados nas descrições e comentários das espécies)

\section{Begonia}

Begonia albido-setulosa 72

Begonia alchemilloides $17,18,54,73$

Begonia altamiroi $20,21,34,112$

Begonia angularis $24,25,28,87$

B. angularis var. angustifolia .25

Begonia angulata $25,27,28$

B. angulata var. campos-portoi ....... 28, 29

B. angulata var. serrana.

28,29

Begonia apparicioi ....... 20, 21, 33, 34, 112

Begonia argyrostigma ............................... 86

Begonia binotii ............................................ 98

Begonia bonitoensis ..................................... 68

Begonia brasilia ........................................... 72

Begonia brasiliensis .................................. 52

Begonia brasiliana ..................................... 72

Begonia castaneifolia ................................. 58

Begonia ciliata .............................................. 72

Begonia cilibracteata ................................ 52

Begonia convolvulacea ........ 36, 37, 59, 81

Begonia crenulata

Begonia cucullata ......... 39, 40, 41, 42, 43

B. cucullata var. arenosicola ................... 42

B. cucullata var. hookeri ........................... 41

B. cucullata var. spatulata ....................... 42

Begonia cucullifolia ..................................... 41

Begonia curtii ..................... 45, 46, 47, 48

Begonia dasycarpa ................................... 119

Begonia dasypoda ........................................ 72

Begonia digitata .................. 50, 51, 79, 85

B. digitata var. rufescens ........................ 51

Begonia dispar ............................................ 41

Begonia elata ............................................. 52

Begonia elatior ......................................... 104

Begonia fischeri ................. 18, 52, 53, 73

B. fischerivar. brasiliensis ............ 52, 53

B. fischerivar. brevipilosa ...................... 53

B. fischerivar. crenato-glabra ............... 53

B. fischerivar. crenulato-glabra ............ 53

B. fischerivar. elata ................................. 52

B. fischerivar. ermani .............................. 53

B. fischerivar. eufischeri ............... 52, 53

B. fischerivar. Klugii ................................. 53

B. fischerivar. macroptera ..................... 53

B. fischerivar. malvacea ......................... 53
B. fischeri var. moritziana ...................... 52

B. fischerivar. palustris ......................... 53

B. fischeri var. tovarensis .............. 52, 53

Begonia fruticosa ............... 37, 58, 59, 81

Begonia galeotii.

111

Begonia gardneri ...................... 60, 61, 105

Begonia gehrtii ........................................... 91

Begonia geniculata .................................... 36

Begonia grandis ........................................ 104

Begonia grisea ......................... 64, 65, 120

Begonia hastata ........................................ 24

Begonia heringeri ............................. 67, 68

Begonia hirtella .................. 18, 54, 72, 73

B. hirtella var. nana ................................... 73

Begonia hispida ........................................... 75

Begonia hoehneana ...................................... 18

Begonia hookeri ............................................. 41

Begonia huberi ........................................... 104

Begonia hugelii .................................. 74, 75

Begonia humilis .......................................... 72

Begonia incisoserrata ....... 51, 78, 79, 85

Begonia inermis ....................................... 104

Begonia integerrima ........... 37, 49, 80, 81

B. integerrima var. cardioides ............... 80

Begonia jairii ............................................. 119

Begonia kaietukensis ............................... 52

Begonia lacustris ......................................... 52

Begonia leptophylla .................................... 17

Begonia lobata ........................................................ 111

Begonia longibarbata ............................. 122

Begonia longipes ........................................ 104

Begonia luxurians ................ 51, 79, 84, 85

B. luxurians var. sampaiona ..................... 85

Begonia maculata ............................ 86, 87

B. maculata var. argentea ........................ 87

B. maculata var. elegantissima ............... 87

B. maculata var. wightii .............................. 87

Begonia moysesii ........................ 90, 91, 99

Begonia neocomensium .................... 92, 93

Begonia aff. nuda ........................... 93, 94

Begonia nuda ............................................... 94

Begonia obliqua .............................................. 52

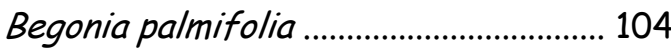

Begonia paludicola ....................................... 41 
Begonia patula 52

Begonia paulensis ............. 91, 98, 99, 125

Begonia platanifolia ...... 61, 102, 103, 105

Begonia populifolia .................................... 52

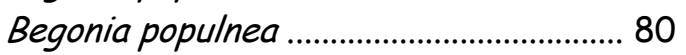

Begonia punctata ……................................ 86

Begonia ragozini .......................................... 64

Begonia reniformis ................. 61, 104, 105

Begonia repens .......................................... 36

Begonia reticulata ....................................... 27

Begonia riedelii ....................... 34, 109, 110

Begonia roraimensis ............................... 52

Begonia rufa .............. 20, 21, 34, 111, 112

Begonia rugosa .............................................. 36

Begonia ruhlandiana ................................... 65

Begonia saxicola ...................................... 120

Begonia scandens ..................................... 36

Begonia sellovii .............................................. 41

Begonia sellowii ............................................ 41

Begonia semperflorens ..................... 42, 43

Begonia setaria ............................................ 41

Begonia setosa ............................................ 52

Begonia splendens ..................................... 58

Begonia tovarensis ..................................... 52

Begonia truncate ...................................... 104

Begonia ulei .................................................. 52

Begonia uliginosa ....................................... 52

Begonia ulmifolia .......................... 119, 120

Begonia unialata ........................................... 36

Begonia valdensium

$28,34,109,110,121,122$

B. valdensium var. angustior ................. 122

Begonia velata ............................................... 45

Begonia vellerea ......................................... 52

Begonia velutina .......................................... 111

Begonia vernicosa ..................................... 111

Begonia verticillata ..................................... 50

Begonia venosa ............................................. 46
Begonia villosa ............................................. 72

Begonia vitifolia ......................................... 104

Begonia washingtoniana .......................... 102

Begonia zebrina ......................................... 24

Begonia sp. .................................... 99, 125

\section{Donaldia}

Donaldia ulmifolia 119

\section{Ewaldia}

Ewaldia ferruginea .................................... 111

Ewaldia lobulata .......................................... 111

\section{Gaerdtia}

Gaerdtia maculata ..................................... 86

Pritzelia

Pritzelia angulata ........................................ 27

Pritzelia zebrina ........................................ 24

\section{Scheidweileria}

Scheidweileria digitata ............................. 50

Scheidweileria incisoserrata .................. 78

Scheidweileria luxurians .......................... 84

\section{Trendelenburgia}

Trendelenburgia fruticosa ...................... 58

\section{Wageneria}

Wageneria convolvulacea ......................... 36

Wageneria hugelii ....................................... 74

Wageneria incisoserrata .......................... 78

Wageneria longipes ................................. 104

Wageneria reniformis ............................ 104

Wageneria rugosa ...................................... 36

Wageneria schottiana ............................... 36

Wageneria vitifolia ..................................... 104 


\section{BIBLIOGRAFIA}

ALMEIDA, D.S. 1996. Florística e estrutura de um fragmento de Floresta Atlântica no município de Juiz de Fora, MG. Dissertação de Mestrado. Universidade Federal de Viçosa. Minas Gerais. 91p.

A.P.G. [Angiosperm Phylogeny Group] II. 2003. An update of the Angiosperm Phylogeny Group classification for the orders and families of flowering plants: APG II. Botanical Journal of Linnaeus Society 141: 399-436.

ARAÚJO, D.D. \& C.G. COSTA. 1972. Estudos anatômico-ecológicos de Begonia maculata Raddi. Anais da Academia Brasileira de Ciências 44(2): 317-336.

BARKLEY, F.A. 1972. Key to the sections of the Begoniaceae. The Buptonian, 1(3): 1-7.

BARKLEY, F.A. \& A. BARANOV. 1972. The sections of Begoniaceae. The Buptonian, 1(1): 18.

BENTHAM, G. \& J.D. HOOKER. 1883. Genera Plantarum. vol.3, part.2. Lovell Reeve. Williams and Norgate: London.

BRADE, A.C. 1957B. Flora do Itatiaia. I. As "Begoniaceae" como fator fisionômico. Rodriguésia 20(32): 15-166, 7 est.

BRANDÃO, M. 2000. Cerrado. In: M.P. MENDONÇA \& L.V. LINS. Lista vermelha das Espécies Ameaçadas de Extinção da Flora de Minas Gerais. Belo Horizonte, Fundação Biodiversitas, Fundação Zoo-Botânica, p.55-53.

BRUMITT, R.K. \& C.E. POWELL. Authors of Plant Names. Royal Botanic Gardens, Kew.

BURT-UTLEY, R.K. 1986. Studies on Middle American Begonia (Begoniaceae) II. Brittonia, 38(4):333-339.

CCN. 2009. Catálogo Coletivo Nacional de Publicações Seriadas. Instituto Brasileiro de Informação em Ciência e Tecnologia. Disponível em:

http://www.ibict.br/secao.php?cat=CCN.

CHASE, M.W.; D.E. SOLTIS; R.G. OLMSTEAD; D. MORGAN; D.H. LES; B.D. MISHLER; M.R. DUVAL; R.A. PRICE; H.G. HILLS; Y.-L. QIU; K.A. KRON; J.H. RETTIG; E. CONTI; J.D. PALMER; J.R. MANHART; K.J. SYTSMA; H.J. MICHAELS; K.G. KAROL; W.D. CLARK; M. HEDRÉN; B.S. GAUT; R.K. JANSEN; K.-J. KIM; C.F. WIMPEE; J.F. SMITH; G.R. FURNIER; S.H. STRAUSS; Q.-Y. XIANG; G.M. PLUNKETT; P.S. SOLTIS; S.M. SWENSEM; S.E. WILLIAMS; P.A. GADEK; C.J. QUINN; L.E. EGUIARTE; E. GOLDENBERG; G.H. LEARN JR; S.W. GRAHAM; S.C.H. BARRET; S. DAYANADIAN \& V.A. ALBERT. 1993. Phylogenetics of seed plants: an analysis of nucleotide sequences from the plastid gene rbdL. Annals of the Missouri Botanical Garden 80(3): 528-577. 
CLEMENT, W.L.; M.C. TEBBIT; L.L. FORREST; J.E. BLAIR; L. BROUILLET; T. ERIKSSON \& S.M. SWENSEN. 2004. Phylogenetic position and biogeography of Hillebrandia sandwicensis (Begoniaceae): a rare Hawaiian relict. Amer. J. Bot. 91:905-917.

COSTA, M.R.C.; G. HERRMANN; C. MARTINS; L.V. LINS \& I.R. LAMAS. 1998. Biodiversidade em Minas Gerais: um atlas para sua conservação. Belo Horizonte, Fundação Biodiversitas. 94p.

CRONQUIST, A. 1968. The evolution and classification of flowering plants. New York. National Science Foundation to the New York Botanical Garden. 396p.

CRONQUIST, A. 1981. An Integrated System of Classification of Flowering Plants. Columbia University Press, New York. p. 427-429.

DAHLGREN, R.M.T., H.T. CLIFFORD \& P.F. YOE. 1980. A revised system of classification of the angiosperm. Botanical Journal of Linnaeus Society 80: 91-124.

DAU, L.; F. SEGADAS-VIANNA \& W.T. ORMOND. Begoniaceae. In. I.B. Trindade \& F. Segadas-Vianna, Eds. Flora ecológica de restingas do sudeste do Brasil, Rio de Janeiro, UFRJ, Museu Nacional, v.20, 1-3p.

DE CANDOLLE, A.P. 1859. Mémoire sur famille du Begoniacées. Annales des Sciences Naturalles Botanique, sér.4, 11:93-194.

DE CANDOLLE, A.P. 1861. Begoniaceae. In: Martius, C.P.F., ed. Flora Brasiliensis, 4(1):337396.

DOORENBOS, J.; M.S.M. SOSEF \& J.J.F.E. DE WILDE. 1998. The sections of Begonia. Wageningen Agricultural University Papers. 98-2. 266p.

DUARTE, A.P. 1961. Considerações acerca do comportamento e dispersão de algumas espécies de Begônias do Estado da Guanabara. Arq. Jard. Bot. Rio 17:56-105.

FONTES, M.A.L. 1997. Análise da composição florística das florestas nebulares do Parque Estadual do Ibitipoca. Dissertação de Mestrado. Universidade Federal de Lavras. Minas Gerais. 131p.

FONT QUER, P. 1953. Diccionario de Botánica. Ed. Labor, Barcelona.

FORREST, L.L. \& P.M. HOLLINGSWORTH. 2003. A recircunscription of Begonia based on nuclear ribosomal sequences. Plant Syst. Evol. 241: 193-211.

FORREST, L.L.; M. HUGHES \& P.M. HOLLINGSWORTH. 2005. A phylogeny of Begonia using nuclear ribosomal sequence data and morphological characters. Syst. Bot. 30(3): 671-682.

GAUTHIER, R. 1950. The nature of the inferior ovary in genus Begonia. Contributions of Institut de Botanique Universite de Montréal 66: 5-91. 
GeoMINAS. 2009. Programa Integrado de uso da Tecnologia de Geoprocessamento pelos Órgãos do Estado de Minas Gerais. Disponível em: http//WWW.geominas.mg.gov.br.

GIULIETTI, A.M.; J.R. PIRANI \& R.M. HARLEY. 1997. Espinhaço range region - Eastern Brazil. In: S. D. DAVIS et al. Centres of Plant Diversity Cambridge, UK, p. 397404. v.2.

GOLDING, J. 1982. Begonia nomenclature. Begonia cucullata Willdenow and included species. Phytologia 50(6): 330-356.

GOLDING, J. \& D.C. WASSHAUSSEN. 2002. Begoniaceae, Edition 2. Part. I: Annotated Species List. Part. II: Illustrated Key. Smithsonian Institution, 43:1-289.

HARRIS, J.G. \& M.W. HARRIS. 2001. Plant Identification Terminology: An Illustrated Glossary. $2^{\text {nd }}$ ed. Missouri Botanical Garden Library. 206p.

HICKEY, L.J. 1973. Classification of Architeture of Dicotyledonous Leaves. Amer. J. Bot. 60(1):17-33p.

HOLMGREN, P.K., N.H. HOLMGREN \& L.C. BARNETT. 1990. Index Herbariorum: The Herbaria of the World. New York Botanical Garden, New York.

HUTCHINSON, J. 1973. The families of flowering plants: arranged according to a new system based on their probable phylogeny. $3^{a} \mathrm{ed}$. Oxford University Press. 968p.

IRMSCHER, E. 1925. Begoniaceae. In: Engler, A. \& Prantl., K. eds. Die natürlichen Pflanzenfamilien. 2ed. v.21, 548-588p.

IRMSCHER, E. 1953. Systematische studien über Begoniaceen des tropischen Sudamerickas besonders Brasiliens. Botanische Jahrbücher für Systematik 76(1): 1-102.

IUCN. 2001. IUCN Red List Categories and Criteria, Version 3.1. Prepared by IUCN Species Survival Commission. IUCN, Gland, Switzerland and Cambridge, United Kingdom.

JACQUES, E.L. 1996. Begoniaceae. In: M.P.M. Lima \& R. Guedes-Bruni (orgs.). Reserva Ecológica de Macaé de Cima, Nova Friburgo - RJ: Aspectos Florísticos das Espécies Vasculares. Jardim Botânico do Rio de Janeiro. Rio de Janeiro, vol.2, p. 93-103.

JACQUES, E.L. 1999. Flora da Serra do Cipó, Minas Gerais: Begoniaceae. Bol. Bot. Univ. São Paulo 18:33-37.

JACQUES, E.L. 2002. Estudos Taxonômicos das Espécies Brasileiras do gênero Begonia L. (Begoniaceae) com placenta partida. Tese de Doutorado. Instituto de Biociências. Universidade de São Paulo. São Paulo. 319p.

JACQUES, E.L. 2003. Flora de Grão-Mogol, Minas Gerais: Begoniaceae. Bol. Bot. Univ. São Paulo 21(1): 107. 
JACQUES, E.L. 2008. Begonia /unaris E.L. Jacques (Begoniaceae), uma nova espécie para o Estado do Rio de Janeiro, Brasil. Rodriguésia 59(1): 259-263.

JACQUES, E.L. \& MAMEDE, M.C.H. 2004. Novelties in Begonia (Begoniaceae) from the coastal forests of Brazil. Brittonia 56(1): 75-81.

JUDD, W.S.; C.S. CAMPBELL; E.A. KELLOG; P.F. STEVENS \& M.J. DONOGHU. 2009. Sistemática Vegetal $3^{a}$ ed. Um enfoque Filogenético. Editora Artmed, 632p.

KLOTZSCH. J.F. 1854. [sem título]. Bericht über die zur Bekanntmachunggeeigneten Verhandlungen der Königl. Preuss. Akademie der Wissenschaften zu Berlin 1854: 119-128.

KLOTZSCH, J.F. 1855a. Begoniaceen - Gattungen und Arten. Berlin, Nicolaischen Buchhandlungen. 135p.

KLOTZSCH, J.F. 1855b. Begoniaceen - Gattungen und Arten. Abhandlungen der Königl. Akademie der Wissenchaften zu Berlin 121-255.

KOLLMANN, L.J.C. 2003. Begonia ruschii L. Kollmann (Begoniaceae), uma nova espécie da Flora Atlântica do Espírito Santo, Brasil. Bol. Mus. Biol. Prof. Mello Leitão. Ser. Bot. 15:29-33.

KOLLMANN, L.J.C. 2006a. Begonia novalombardiensis L. Kollmann (Begoniaceae), une nouvelle espèce de la forêt atlantique de l'Etat de l'Espírito Santo, Brésil. Candollea 61(1)/89-92.

KOLLMANN, L.J.C. 2006b. Begoniaceae da Estação Ecológica de Santa Lúcia, município de Santa Teresa, Estado do Espírito Santo, Brasil. Bol. Mus. Biol. Prof. Mello Leitão. Ser. Bot. 20:07-25.

KOLLMANN, L.J.C. 2008. Duas novas espécies de Begonia (Begoniaceae) do Espírito Santo, Brasil. Rodriguésia 59(1): 155-160.

KUHLMANN, E.; M. BRANDÃO \& J.P. LACA-BUENDIA. 1994. Considerações sobre a cobertura vegetal do Estado de Minas Gerais. Belo Horizonte. Daphne, 1(4):8-16p.

LAWRENCE, G.H.M.; A.F. BUCHHEIM; G.S. DANIELS. \& H. DOLEZAL. 1968. P.B.H. Botanicum Periodicum Huntianum. Hunt Botanical Library, Pittsburgh.

MARTINS, C.S. 2000. Caracterização Física e Fitogeográfica de Minas Gerais. In: Mendonça, M.P. \& Lins, L.V. Lista vermelha das espécies ameaçadas de extinção da flora de Minas Gerais. Fundação Biodiversitas, Fundação Zôo-Botânica de Belo Horizonte, Belo Horizonte 35-43p.

MENEZES, N.L. \& A.M. GIULIETTI. 2000. In: M.P. MENDONÇA \& L.V. LINS. Lista vermelha das Espécies Ameaçadas de Extinção da Flora de Minas Gerais. Belo Horizonte, Fundação Biodiversitas, Fundação Zoo-Botânica, p.65-73.

PAYNE, W.W. 1978. A Glossary of Plant Hair Terminology. Brittonia, 30(2)239-255p. 
PLANA, V. 2003. Phylogenetic relationships of the Afro-Malagasy members of the large genus Begonia inferred from trnL intron sequences. Systematic Botany 28: 693704.

RADFORD, A.E.; W.C. DICKISON; J.R. MASSEY \& C.R. BELL. 1974. Vascular Plant Systematics. Harper \& Row Publ., New York, 891p.

ROTH, I. 1968. Organografia comparada de las plantas superiores. Universidad Central de Venezuela. Ediciones de la Biblioteca. Caracas, 245p.

SCHWARZBACH, A. \& E. RICKLEFS. 2000. Systematic affinities of Rhizophoraceae and Anisophyllaceae, and intergenetic relationships withing Rhizophoraceae based on chloroplast DNA, nuclear ribosomal DNA, and morphology. American Journal of Botany 87: 547-564.

SILVA, A.F. 2000. Floresta Atlântica. In: M.P. MENDONÇA \& L.V. LINS. Lista vermelha das Espécies Ameaçadas de Extinção da Flora de Minas Gerais. Belo Horizonte, Fundação Biodiversitas, Fundação Zoo-Botânica, p. 45-53.

SILVA, S.J.G. 1998. Begoniaceae da Mata Atlântica na Serra do Mar do Estado de São Paulo, Brasil. Dissertação de Mestrado, Instituto de Biociências, Universidade de São Paulo. São Paulo. 137p.

SILVA, S.J.G. 1992. Flora Fanerogâmica da Ilha do Cardoso (São Paulo, Brasil): Begoniaceae. Instituto de Botânica. São Paulo, SP, Brasil, vol.3, 27-36.

SILVA, S.J.G. \& MAMEDE, M.C.H. 2001. Begoniaceae da Mata Atlântica da Serra do mar do Estado de São Paulo, Brasil. Bol. Inst. de Bot. 15: 1-51.

SMITH, L.B. \& B.G. SCHUBERT. 1941. Revision de las especies Argentinas del genero Begonia. Darwiniana 5: 78-117.

SMITH, L.B. \& R.C. SMITH 1971. Begoniáceas. In: Reitz, R., ed. Flora Ilustrada Catarinensis. Itajaí, Herbário Barbosa Rodrigues, BEGO I. 128p.

SMTH, L.B. \& D.C. WASSHAUSEN. 1986. Begoniaceae. In: Flora de Venezuela. Washington, USA. v.4, part. 1.

SMITH, L.B.; D.C. WASSHAUSEN; J. GOLDING \& C.E. KAREGEANNES. 1986. Begoniaceae: Part. I: Illustrated Key. Part. II: Annotated Species List. Smithsonian Contributions to Botany, 60:1-584.

SOLTIS, D.E.; et al. 2000. Angiosperm phylogeny inferred from a combined data set of $18 S$ rDNA, rbcL, and atpB sequences. Botanical Journal of the Linean Society 133: 381-461.

SOUZA, V.C. \& H. LORENZI. 2008. Botânica Sistemática. Guia ilustrado para identificação das famílias de Angiospermas da flora brasileira, baseado em APG II. Nova Odessa, Instituto Plantarum de Estudos da Flora LTDA. $2^{a}$ ed. p. 447. 
STAFLEU, F.A. \& COWAN, R.S. 1976-1988. Taxonomic Literature: A selective guide to botanical publications and collections, with dates, commentaries and types. 2nd much enlarged ed. v. 1-7, suppl. 1-6.

SWENSEN, S.M.; J.N. LUTHI \& L.H. RIESELBERG. 1998. Datiscaceae revisited: monophyly and the sequence of breeding system evolution. Systematic Botany 23: 157-169.

SWENSEN, S.M.; W.L. CLEMENT; L.L. FORREST \& M.C. TEBBITT. 2001. Hillebrandia sandwicensis. Evolutionary relationships and biogeography. In: Botany 2001: plants and people, abstracts; 95. Botanical Society of America, Albuquerque, New Mexico, USA.

TEBBITT, M.C.; L.L. FORREST; W.S. HOOVER \& S.M. SWENSEN. 2001. Relationships of fleshy-fruited Asiatic Begonia (Begoniaceae) based on ITS sequence data and restriction site mapping of PCR amplified chloroplast and mitochondrial fragments. In Botany 2001: plants and peoples abstracts, 95. Botanical Society of America, Albuquerque, New Mexico, USA.

VELOSO, H.P.; A.L.R. RANGEL FILHO \& J.C.A. LIMA 1991. Classificação da vegetação brasileira, adaptada a um sistema universal. Rio de Janeiro, IBGE, 124p.

WAGSTAFF, S.J. \& M.I. DAWSON. 2000. Classification, origin, and patterns of diversification of Corynocarpus (Corinocarpaceae) inferred from DNA sequences. Systematic Botany 25: 134-149.

WARBURG, O. 1894. Begoniaceae. In: Engler, A. \& Prantl., K. eds. Die natürlichen Pflanzenfamilien. Leipzig: Wilhelm Engelmann. v.3, n.6a, p. 121-150.

WEBERLING, F. 1989. Morfology of flowers and inflorescences. Traduzido por R.J. Pankhurst, Cambridge University, 405p. 